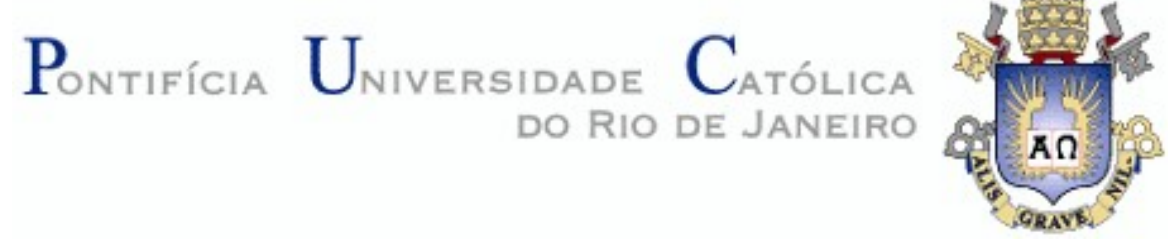

Marco Antonio Martins Junior

\title{
A ‘Força do Povo' nas políticas públicas do Rio de Janeiro: as marcas espaciais de Leonel Brizola na metrópole carioca
}

\section{Tese de Doutorado}

Tese apresentada como requisito parcial para obtenção do grau de Doutor em Geografia pelo programa de Pósgraduação em Geografia, do Departamento de Geografia e Meio Ambiente da PUC-Rio.

Orientador: Prof. Augusto César Pinheiro da Silva Coorientador: Prof. André Lima de Alvarenga 
A 'Força do Povo' nas políticas públicas do

Rio de Janeiro: as marcas espaciais de Leonel Brizola na metrópole carioca

Tese apresentada como requisito parcial para obtenção do grau de Doutor pelo Programa de PósGraduação em Geografia da PUC-Rio. Aprovada pela Comissão Examinadora abaixo:

Prof. Augusto César Pinheiro da Silva

Orientador

Departamento de Geografia e Meio Ambiente - PUC-Rio

Prof. André Lima de Alvarenga

Coorientador

Departamento de Geografia e Meio Ambiente - PUC-Rio

Prof. Glaucio José Marafon Instituto de Geografia - UERJ

Prof. Leonardo Freire Marino Departamento de Geografia - UERJ

Profa. Susana Mara Miranda Pacheco Departamento de Geografia Humana - UERJ

Prof. Álvaro Vicente Graça Truppel Pereira do Cabo Universidade Cândido Mendes - UCAM

Rio de Janeiro, 17 de dezembro de 2021 
Todos os direitos reservados. É proibida a reprodução total ou parcial do trabalho sem autorização da universidade, do autor e da orientadora.

\section{Marco Antonio Martins Junior}

Professor das redes públicas do Rio Ex de Caxias. Rede privada também. Graduado em Geografia pela UERJ. Pós-graduação lato sensu em Sociologia Urbana pela UERJ. Mestre em Geografia pela PUC Rio.

Ficha Catalográfica

Martins Junior, Marco Antonio

A 'força do povo' nas políticas públicas do Rio de Janeiro : as marcas espaciais de Leonel Brizola na metrópole carioca / Marco Antonio Martins Junior ; orientador: Augusto César Pinheiro da Silva ; coorientador: André de Lima Alvarenga. - 2021.

167 f. : il. color. ; $30 \mathrm{~cm}$

Tese (doutorado)-Pontifícia Universidade Católica do Rio de Janeiro, Departamento de Geografia e Meio Ambiente, 2021.

Inclui bibliografia

1. Geografia e Meio Ambiente - Teses. 2. Democratização. 3. Trabalhismo. 4. Marcas. 5. Espaço público. 6. Espaço político. I. Silva, Augusto César Pinheiro da. II. Alvarenga, André de Lima. III. Pontifícia Universidade Católica do Rio de Janeiro. Departamento de Geografia e Meio Ambiente. IV. Título.

CDD: 910 
Para um grande amigo, amor e companheiro em qualquer dimensão que esteja. Aquele que me ensinou a amar a Portela, ter paixão pelo Botafogo e me tornar brizolista. Meu pai Marco Antônio Martins (em memória) 


\section{Agradecimentos}

Nestes cinco anos de doutorado, diversas pessoas contribuíram para a escrita deste texto, através de suporte pessoal, acadêmico ou político. A todos o meu agradecimento.

Ao meu amigo e Orientador, Professor Doutor Augusto César Pinheiro da Silva pela dedicação e paciência e pela eficiente condução acadêmica e intelectual de todo processo.

Ao meu coorientador, Professor Doutor André de Lima Alvarenga, também pela dedicação e eficiência acadêmica e por ser muito cirúrgico em suas observações.

A meus companheiros do Grupo de Estudos de Gestão Territorial do Estado do Rio de Janeiro (Geterj).

Um agradecimento especial para Adriana Benazzi, amiga e irmã para todas as horas, também membro do Geterj.

A rede municipal de Duque de Caxias pela licença remunerada concedida para que eu pudesse concretizar o projeto. A rede municipal do Rio de Janeiro.

Aos colégios São Paulo e Santo Agostinho Leblon, pelo apoio.

Aos meus irmãos de Santo do Grupo Espírita Vovó Sá Maria da Bahia, em particular a minha Mãe de Santo.

A meus filhos, Gustavo e Letícia, meus dois amores para toda vida.

A minha mãe e meus irmãos, grandes companheiros de batalha.

A Aimée Miranda pela sua dedicação.

A Paola Martins, Letícia Martins, Daniela Andrade, Thalita Carvalho, a Sônia Coutinho e Álvaro Coutinho, Cecília e a Álvaro do Cabo.

A todos os meus amigos Simpáticos, pelas conversas sempre elucidativas sobre o assunto.

Aos Agostinianos Raiz.

A todos aqueles que trilharam meu caminho e fazem parte da minha vida.

O presente trabalho foi realizado com apoio da Coordenação de Aperfeiçoamento de Pessoal de Nível Superior - Brasil (CAPES) - Código de Financiamento 001. 


\section{Resumo}

Martins Junior, Marco Antonio; Silva, Augusto César Pinheiro da; Alvarenga, André de Lima. A 'Força do Povo' nas políticas públicas do Rio de Janeiro: as marcas espaciais de Leonel Brizola na metrópole carioca. Rio de Janeiro, 2021. 167p. Tese de Doutorado - Departamento de Geografia e Meio Ambiente, Pontifícia Universidade Católica do Rio de Janeiro.

No final da década de 1970 o Brasil passou por profundas transformações políticas, devido o processo de abertura realizado pelo governo brasileiro de então. A partir daí houve o fim dos Atos Institucionais, como o AI-2 e o AI-5, que permitiram o fim do bipartidarismo, a redemocratização e o retorno dos exilados, dentre eles Leonel de Moura Brizola. Brizola radicou seu domicílio político no Rio de Janeiro, por observar na metrópole carioca, a importância de sua capitalidade e a possibilidade de criar visibilidade na política nacional. No ano de 1982 foi eleito governador do estado do Rio de Janeiro e os espaços carioca e fluminense se tornaram o "laboratório" do Novo Trabalhismo trazido por Brizola a partir da Carta de Lisboa, documento fundador do Partido Democrático Trabalhista (PDT). Na sua gestão a frente do estado vai ser notabilizada por políticas públicas segmentadas para populações mais vulneráveis, que deixaram marcas espaciais como os Centros Integrados de Educação Pública (CIEPs), além de uma mudança radical nas políticas voltadas para habitação, como o Programa Pra Cada Família, um Lote, que procurou regularizar a situação fundiária e urbanizar as favelas e outras áreas carentes tanto da cidade quanto do estado do Rio de Janeiro. Destaco também como importante marca do seu período na política carioca e fluminense, a criação de um movimento espontâneo, que se apropriou de um dos espaços públicos mais centralizados da metrópole carioca, a Praça Marechal Floriano, também conhecida como Cinelândia.

\section{Palavras-chave}

Abertura; democratização; trabalhismo; capitalidade; marcas; matrizes; espaço público; espaço político. 


\section{Abstract}

Martins Junior, Marco Antonio; Silva, Augusto César Pinheiro da (Advisor); Alvarenga, André de Lima. (Coadvisor). The "people's strength" in the public politics from Rio de Janeiro: Leonel Brizola's spatial marks in the Rio de Janeiro metropolis. Rio de Janeiro, 2021. 167p. Tese de Doutorado - Departamento de Geografia e Meio Ambiente, Pontifícia Universidade Católica do Rio de Janeiro.

In the late seventies, Brazil has gone through profound political changes due to the opening process carried out by the Brazilian government at that time. From then on, the Institutional Acts, such as "AI-2" and "AI-5", came to an end, which allowed the end of bipartisanship, the redemocratization and the return of exiles, among them Leonel de Moura Brizola. Brizola settled his political domicile in Rio de Janeiro, for observing in the metropolis the importance of its "capitality" and the possibility of creating visibility in the national politics. He was elected the governor of the state of Rio de Janeiro in 1982, and either the space of the city or of the state of Rio de Janeiro turned into the "laboratory" of the New Labourism brought by Brizola from the Lisbon Charter, the founding document of the Democratic Labor Party (PDT). His administration at the head of the state will be distinguished by segmented public policies for the most vulnerable communities, which have left spatial marks such as the Integrated Public Education Centers (Centros Integrados de Educação Pública -CIEPs), besides a radical change in policies regarding housing development, such as the program "Pra cada família um lote", which aimed to regularize the agrarian situation and urbanize slums and other poor areas in both city and in state of Rio de Janeiro. I also highlight as an important spatial mark in Brizola's period in the politics of the city and state of Rio de Janeiro, one of the most centralized public spaces in the metropolis of Rio de Janeiro - Praça Marechal Floriano - also known as Cinelândia, which has been appropriated for the creation of a spontaneous movement.

\section{Keywords}

Openness; democratization; labourism; marks; matrices; public space; political space. 


\section{Sumário}

Introdução.

1. O retorno do 'caudilho' à cena política brasileira: a formação do Partido Democrático Trabalhista (PDT) na redemocratização do país

1.1. Antecedentes ........................................................................ 27

1.2. Da transição controlada à abertura: novos pactos políticos e a redemocratização................................................................. 28

1.3. O retorno de Brizola ................................................................ 35

1.4. O retorno à vida política no Rio de Janeiro e a perda da legenda do Partido Trabalhista Brasileiro (PTB) ....................................... 36

1.5. O Trabalhismo varguista, uma das bases fundadoras do 'novo trabalhismo' ......................................................................... 40

1.6. O "Novo Trabalhismo" e a "invenção do Brizolismo".......................46 46

1.7. A Criação do Partido Democrático Trabalhista (PDT) ...................... 51

2. "Brizola na cabeça": capitalidade e poder local da Cidade Maravilhosa no jogo político nacional.............................................. 57

2.1. Brizola "na cabeça": as eleições de 1982 no Rio de Janeiro............... 59

2.1.1. O contexto nacional nas eleições de 1982 .................................. 59

2.1.2. O Rio de Janeiro nas eleições de 1982: Brizola contra as máquinas de voto .............................................................. 62

2.2. Rio de Janeiro: a importância da capitalidade para institucionalização do Brizolismo

3. Rio de Janeiro: a cidade "vitrine" do Brizolismo - formas, conteúdos e estratégias espaciais

3.1. Rio de Janeiro: capital e espaço de territorialidade da política brizolista

3.2. A Carta de Lisboa: documento matriz das políticas brizolistas que deixaram marcas nos espaços carioca e fluminense ............100

3.2.1. Programa Especial de Educação - marcas e matrizes ................ 107

3.2.2. Programa Cada família, um Lote: marcas e matrizes.................. 112

3.2.3. PROFACE: marca e matriz ................................................... 116

3.2.4. Programa Uma Luz na escuridão: marca e matriz .................... 117

3.2.5. Projeto Mutirão Comunitário: marcas e matriz .......................... 117

3.2.6. Fim da "Política do Pé na Porta" ............................................... 118

3.3. O Brizolismo como instrumento de análise socioespacial: símbolos e representações

4. A Cinelândia como marca e matriz, a Brizolândia: do espaço público ao espaço da política brizolista ........................................ 124

4.1. A Brizolândia: lugar e ação popular do brizolismo......................... 126

4.1.1. O surgimento da Brizolândia ............................................... 126

4.1.2. Brizolândia: a relevância da praça para o movimento político......133

4.2. Brizolândia: apropriação e subversão do espaço público ...............136

4.3. A Brizolândia: espaço político ou "apolítico"? .................................. 141 
5. Considerações Finais .

151

6. Referências bibliográficas 


\section{Lista de imagens}

Imagem 1: Retorno de Brizola ao Brasil.............................................. 36

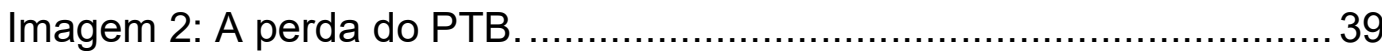

Imagem 3: Cartaz do Encontro de Lisboa de 1979. Encontros dos Trabalhistas do Brasil com os do exílio. ...............................50

Imagem 4: Assinatura da Carta de Lisboa, 1979 ................................. 50

Imagem 5: Brizola sendo conduzido por taxistas após tomar conhecimento do resultado das eleições.............................78

Imagem 6: Brizola tomando posse na Assembleia Legislativa do Rio

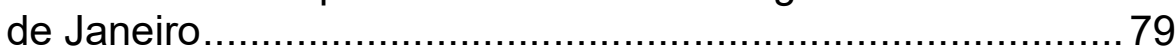

Imagem 7: Secretário de Trabalho e Habitação Carlos Alberto de Oliveira ................................................................ 87

Imagem 8: Vice Prefeito do Rio de Janeiro Jó Rezende ........................87

Imagem 9: Abdias do Nascimento com Brizola ................................... 87

Imagem 10: Cacique Juruna ..................................................... 87

Imagem 11: Brizola contra as empresas de ônibus..............................93

Imagem 12: A mídia contra o projeto dos CIEPs.................................. 94

Imagem 13: Brizola e Niemeyer: projeto do sambódromo. .................... 108

Imagem 14: Brizola e Darcy Ribeiro no primeiro desfile na passarela



Imagem 15: Brizola e Darcy Ribeiro no CIEP em Campo Grande. ........ 109

Imagem 16: Brizola e Carlos Nazareth Cerqueira: responsável pela política de segurança do governo pedetista.

Imagem 17: Busto de Getúlio Vargas, primeiro introdutor do trabalhismo na política brasileira.

Imagem 18: Praça Floriano Peixoto: popularmente conhecida como Cinelândia espaço onde foi criado o movimento popular da Brizolândia.

Imagem 19: Brizolistas ocupando as escadarias do Palácio Pedro Ernesto, um dos locais que os integrantes da Brizolândia utilizavam para fazer campanha para Brizola.

Imagem 20: Homenagem a lideranças trabalhistas e nacionalistas....... 132

Imagem 21: Símbolo do Bloco Carnavalesco Órfãos do Brizola. 


\section{Lista de esquemas}

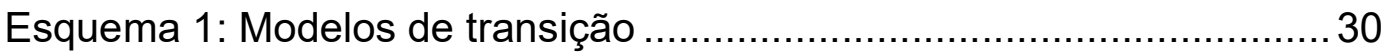

Esquema 2: Grupos do Partido Trabalhista Brasileiro - pré 1964_........... 45

Esquema 3: Trabalhismo e Novo Trabalhismo........................................ 51

Esquema 4: Análise espacial das bases eleitorais .................................73

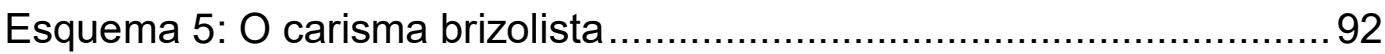

Esquema 6: Concepções do espaço público por Borja .........................142 


\section{Lista de quadros}

Quadro 1: Compromissos da Carta de Lisboa ................................... 48

Quadro 2: Atenções Prioritárias da Carta de Lisboa ............................. 49

Quadro 3: Ações políticas presentes na Carta de Lisboa ....................... 49

Quadro 4: Compromissos prioritários da Carta de Lisboa...................... 77

Quadro 5: Marcas e Matrizes da política brizolista.............................. 105

Quadro 6: Metas do Programa Pra Cada Família, um Lote ...................113

Quadro 7: tipos de praças ....................................................... 133

Quadro 8: Representações sobre Brizola ...................................... 135

Quadro 9: Apropriações do espaço público ....................................... 138

Quadro 10: A classificação do espaços públicos ................................. 146 


\section{Lista de mapas}

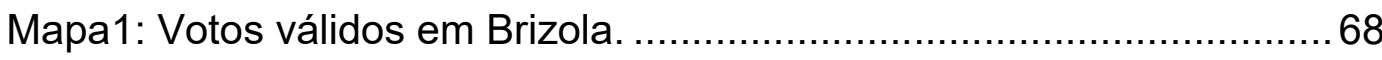

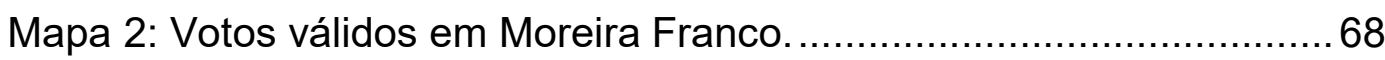

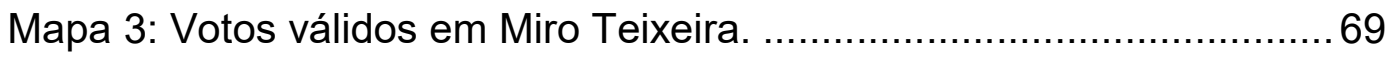

Mapa 4: Distribuição dos CIEPs no Rio de Janeiro ...............................110

Mapa 5: Distribuição dos CIEPs na Região Metropolitana do Rio de

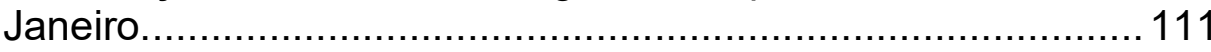

Mapa 6: Mapa do Programa Pra Cada Família, um Lote ...................... 115 


\title{
Lista de Abreviaturas e Siglas
}

\author{
ARENA - Aliança Renovadora Nacional \\ CEDAE - Companhia Estadual de Água e Esgoto \\ CEHAB - RJ - Companhia Estadual de Habitação do Rio de Janeiro \\ CIEP - Centro Integrado de Educação Pública \\ FAFERJ - Federação de Favelas do Estado do Rio de Janeiro \\ FAMERJ - Federação da Associação de Moradores do Estado do Rio de \\ Janeiro \\ MDB - Movimento Democrático Brasileiro \\ PDS - Partido Democrático Social \\ PDT - Partido Democrático Trabalhista \\ PMDB - Partido do Movimento Democrático Brasileira \\ PMERJ - Polícia Militar do Estado do Rio de Janeiro \\ PP - Partido Progressista \\ PSDB - Partido da Social Democracia Brasileira \\ PT - Partido dos Trabalhadores \\ PTB - Partido Trabalhista Brasileiro \\ SETH - Secretária Estadual de Trabalho e Habitação \\ UDN - União Democrática Nacional
}




\section{Introdução}

A escolha do tema da tese vem acompanhada de uma trajetória pessoal, que começou em minha infância, particularmente durante o período das eleições de 1982 para o governo do estado do Rio de Janeiro.

O ano de 1982 ficou marcado por duas situações específicas para mim: a Copa do Mundo da Espanha em que tínhamos uma seleção considerada pelos analistas esportivos como favorita para o título da competição. Ela reunia inúmeros jogadores que jogavam o futebol "refinado", o chamado futebol "arte", porém toda euforia foi tomada por grande frustração com a derrota para Itália por 3 a 2 quando o Brasil precisava apenas de um empate para chegar às semifinais.

A outra situação foram as eleições que acompanhei porque durante todo processo eleitoral meu pai se envolveu como cabo eleitoral tanto de Brizola quanto de candidatos que disputavam a Câmara dos Vereadores do Rio de Janeiro pelo Partido Democrático Trabalhista (PDT).

Vejo relevância em abordar a trajetória de meu pai enquanto partícipe da campanha de Brizola, pois estava no rol de eleitores que acreditavam no chaguismo, mas que foi "seduzido" a partir do momento que a "campanha" do "caudilho" começou a engrenar nas ruas e nos meios de comunicação.

Morávamos na Ladeira dos Tabajaras, favela localizada no bairro de Copacabana, na zona sul do Rio de Janeiro. Esse é outro aspecto importante, porque as favelas sempre foram vistas como territórios de disputas eleitorais. No final dos anos 1970 e início da década de 1980, muitos candidatos já percorriam áreas favelizadas em busca de votos, tendo em seus discursos a oferta da melhoria das condições de vida locais.

Meu pai era comerciário, trabalhava de segunda à sábado e, pela própria força da profissão, era uma pessoa muito comunicativa. A partir da plataforma de campanha brizolista passou a integrar uma legião de cabos eleitorais que ajudaram Brizola no seu objetivo de se tornar chefe do executivo estadual.

Há ainda outra peculiaridade, meu pai se encaixava perfeitamente para função de cabo eleitoral, pois era muito popular onde morava, foi um dos 
fundadores e primeiro mestre sala do bloco local da Unidos de Villa Rica, que posteriormente se tornaria escola de samba. Isso permitia uma capilaridade para trazer candidatos no local e, é claro, pedir votos para o mesmo.

Foi nesse contexto que a política partidária começou a fazer parte do meu cotidiano, primeiro através de candidatos ligados ao campo chaguista e, posteriormente, houve a adesão à candidatura de Brizola, ao pedetismo e ao brizolismo do qual nunca mais deixou.

O ano de 1982 representou uma mudança de rumo com relação à atuação política de meu pai. Esse movimento para o brizolismo e para o apoio à candidatura de Brizola veio através de contatos obtidos a partir de seu trabalho como vendedor. Conheceu um candidato a vereador pelo Partido Democrático Trabalhista, chamado Aldemar Albuquerque (PDT-RJ), de quem se tornou amigo e que até os dias atuais faz parte do meu circulo de convívio.

Através dessa candidatura houve a aproximação com o PDT, pois em princípio se tornou cabo eleitoral da campanha de vereador e, depois, viria a trabalhar em duas frentes, fazendo também a campanha de Brizola.

Nesse momento, comecei a participar da campanha política. Meu pai levava meus irmãos e eu para percorrer vários lugares diferentes da cidade, com candidatos que disputavam o legislativo carioca e fluminense para angariar votos para os pedetistas. Não custa lembrar que o governo federal criou o dispositivo do voto vinculado, o que tornou o trabalho dos cabos eleitorais, muito importante, pois era necessário fazer campanha para vários candidatos do mesmo partido. Lembro perfeitamente das camisas e panfletos distribuídos - tínhamos para governador Brizola, vice Darcy Ribeiro, Senador Saturnino Braga, Deputado Federal Brandão Monteiro, Deputada Estadual Iara Vargas e Vereador Aldemar Albuquerque, todos do Partido Democrático Trabalhista.

Nesse contexto houve minha inserção na vida política, percorrendo diferentes locais da cidade do Rio de Janeiro, em todas as zonas da metrópole carioca, além da Baixada Fluminense.

Nos meus percursos durante a campanha guardo recordação de inúmeros presidentes e representantes de associações de moradores que "conheci" e 
observava suas reivindicações tanto para os candidatos a vereador quanto para deputados estaduais. Era comum ver esses dois postulantes fazendo campanhas "casadas", ou seja, dois candidatos para cargos diferentes aproveitando a mesma estrutura de visita montada, para dinamizar as visitas.

Foi nessa trajetória de envolvimento precoce com a política, que tive conhecimento dos movimentos de associações de moradores e das campanhas pedetistas, envolvendo candidatos para cargos eletivos diversos. Com isso, passei a ouvir as propostas do então candidato ao governo do estado, Brizola.

Outro aspecto que consolidou a minha opção política pelo brizolismo foi frequentar os debates realizados na Brizolândia, movimento brizolista espontâneo que aconteceu na Cinelândia, durante doze anos, de 1982 até 1994. Nas escadarias do Palácio Pedro Ernesto e no entorno de uma barraca montada, eram realizadas a maior parte das reuniões e "comícios" do grupo que se apossou e territorializou a Praça Floriano.

A Cinelândia, transformada em Brizolândia pelos brizolistas, funcionava como um imenso comitê eleitoral a "céu aberto". Na praça os brizolistas se reuniam e discutiam sobre os rumos da campanha política pedetista. Muitos cabos eleitorais frequentavam esse ambiente.

A marca principal era a espontaneidade daqueles que trabalhavam para eleger Brizola. Tínhamos um movimento político e de debates que não se apresentava como acadêmico, mas sim de forma bastante inorgânica. Os cabos eleitorais discutiam estratégias para entrar em redutos de outros candidatos além de não deixar que segmentos partidários de outras legendas se apropriassem da Cinelândia.

Espaços como esses, que frequentei durante a campanha de 1982, ajudaram a popularizar a imagem de Leonel Brizola através de referências e expressões muito comuns, vinculadas à forma popular de se referir ao outro, como exemplo: "estamos fechados com o "homem"” ou "no Centro da Cidade só se fala no 'homem"”, além, é claro, do slogan criado para a sua vitória "Deu Brizola na cabeça". A primeira expressão é utilizada pelos cariocas quando se referem a uma pessoa importante ou que tem autoridade, já a segunda é bastante popular, pois faz deferência ao jogo do 
bicho, um jogo de azar muito comum entre os cariocas, quando acertam em um deles, dizem "deu fulano na cabeça".

Durante o período eleitoral a diversão dos fins de semana era estar nas campanhas políticas, visitar comitês de candidatos do PDT para adquirir materiais de divulgação, percorrer possíveis redutos eleitorais que aderiram a Brizola para distribuir materiais e, caso houvesse e fosse possível, acompanhar algumas visitas a pequenos comícios, realizados pelo líder pedetista na cidade e na Região Metropolitana. Quando sobrava algum tempo, o que fazíamos de diferente era ir para o Maracanã ver o Botafogo jogar.

Brizola foi eleito governador do estado do Rio de Janeiro em 1982, derrotando dois candidatos que faziam parte de grupos políticos consolidados nos territórios carioca e fluminense, Moreira Franco, do Partido Democrático Social (PDS), que tinha apoio de Amaral Peixoto, influente político fluminense e, também do governo federal; e Miro Teixeira, do Partido do Movimento Democrático Brasileiro (PMDB), apadrinhado de Chagas Freitas, que já havia sido governador da Guanabara antes da fusão e era o atual representante do executivo estadual no estado do Rio de Janeiro.

Os anos 1980 foram marcados por momento de grave crise econômica e de grande carestia, que ficava evidenciada espacialmente na cidade e no estado do Rio de Janeiro, por problemas crônicos de habitação, concretizada pela intensa favelização, além de problemas decorrentes desse processo como a falta de saneamento básico, por exemplo.

A eleição de Brizola e sua campanha foram alicerçadas em um discurso que procurava romper com as políticas públicas vigentes até então pautadas no remocionismo de favelas, e que eram temidas por boa parte da população desses espaços.

Brizola partiu de um discurso que procurava angariar o apoio dos movimentos associativistas, que tinham grande penetração nas favelas e nos bairros da zona oeste do Rio de Janeiro, redutos da política chaguista. $\mathrm{O}$ apoio conseguido foi fruto de compromissos de campanha que abandonava as propostas de remoção 
para uma política de regularização fundiária, permitindo aos moradores a posse de suas propriedades, inserindo-os na cidade formal.

Outras duas políticas públicas alardeadas durante a campanha, tinham dois outros campos de atuação bastante sensíveis aos segmentos de populações mais pobres. A ênfase dada à educação, que já havia sido uma marca de seu período enquanto governador do Rio Grande do Sul, quando construiu mais de 5000 escolas. No Rio de Janeiro, no início de seu governo, foi elaborado o Programa Especial de Educação, que teve como principal consequência a criação dos Centros Integrados de Educação Pública (CIEPs), um modelo de escola que favorecia bastante às famílias de baixa renda, pois oferecia educação integral.

A terceira ponta dessas políticas públicas estava vinculada à segurança pública, outro tema também sensível às populações que habitavam as favelas e periferias, consideradas marginalizadas. As políticas de segurança para esses espaços se caracterizavam pela truculência e pelo controle social. A partir do governo Brizola e com o fim das políticas remocionistas, foram valorizadas novas estratégias de policiamento, baseadas na prevenção e na legalidade.

Essas políticas públicas foram importantes mecanismos que permitiram a Brizola e ao PDT modificar a geografia eleitoral da cidade e, posteriormente, do estado do Rio de Janeiro. A mudança observada pode ser exemplificada pelo fim dos redutos chaguistas, principalmente na zona oeste da metrópole carioca. Isso se deve a aproximação com as Associações de Moradores, fruto das ações implementadas durante o período que esteve à frente do governo do estado do Rio de Janeiro.

Com relação ao interior, Brizola consegue mudar sua geografia eleitoral e do voto, efetivamente, a partir do seu segundo mandato quando obteve ampla votação que o elegeu em primeiro turno, além do estabelecimento de alianças políticas com influência no interior do estado, como Anthony Garotinho.

A partir de suas ações políticas e da formação de bases eleitorais, o “caudilho" fez do Rio de Janeiro o "laboratório" das políticas relacionadas ao "Novo Trabalhismo', referendada pela Carta de Lisboa, documento fundador desse movimento político. 
A Carta de Lisboa foi a matriz política e ideológica que norteou as ações do governo brizolista e instituiu marcas nos territórios carioca e fluminense, determinando uma nova força política nesses espaços.

Nesse cenário, o Rio de Janeiro foi pensado como o polo difusor do brizolismo e, também de Brizola, que tinha aspirações políticas mais amplas, com escalas que extrapolavam os limites do território fluminense. $\mathrm{O}$ ex-governador pretendia utilizar a capitalidade e a centralidade da Cidade Maravilhosa para visibilizar sua imagem para todo país, através de um discurso político que valorizava a antiga capital como o "tambor político do Brasil" e onde suas políticas teriam repercussão nacional.

No ano de 1990, quando completei dezesseis anos e pude votar pela primeira vez, me filiei ao Partido Democrático Trabalhista. Após a derrota de Brizola para o executivo federal em 1989, seu grande objetivo foi retomar o executivo do Rio de Janeiro e, com isso, se candidatou ao governo do estado, sendo eleito no primeiro turno. A partir daí, participei de diferentes momentos da militância partidária em campanhas tanto para o executivo federal, estadual como também municipal, além das eleições proporcionais.

A década de 1990 consolidou a força política de Brizola no estado do Rio de Janeiro, mas também foi a partir dela que sua decadência começou a ser notada. O marco inicial foram as eleições para presidência da República em 1994. Os resultados foram pífios e Brizola amargou uma $5^{\text {a }}$ colocação, com uma votação pouco expressiva, com cerca de $3,2 \%$ dos votos, segundo site www.memoriaglobo.globo.com.

No ano de 1998, houve a formação de uma chapa que reuniu Lula e Brizola, sendo o "caudilho" vice de Lula nas eleições de 1998. O resultado, mais um revés, em que as duas lideranças do campo da esquerda, foram suplantadas por Fernando Henrique Cardoso (PSDB), no primeiro turno. Com relação às eleições locais, ou seja, tanto na cidade quanto no estado, Brizola também saiu derrotado. Os candidatos apoiados pelo líder pedetista perderam as eleições para prefeitura em 
1992 e 1996 e também foi derrotado no pleito eleitoral para o governo do estado em $1994^{1}$.

Desde então, Brizola desistiu de seu projeto político nacional que estava alicerçado no estado do Rio de Janeiro. Após três derrotas políticas para o executivo federal, ainda houve tentativas locais como a sua candidatura para o senado em 2002 e para prefeito em que também os resultados eleitorais em nada correspondem às intenções de voto que tinha no início da década de 1990 .

O enfraquecimento do papel político de Brizola no Rio de Janeiro representou a perda da importância do Partido Democrático Trabalhista, que dependeu durante toda sua existência do carisma exercido pelo "caudilho".

Durante esse período observei como membro do partido o enfraquecimento político da legenda e a diminuição de seu papel no cenário político nacional e local. Mesmo no Rio de Janeiro, o Partido Democrático Trabalhista, desde Anthony Garotinho (1999), não elegeu mais nenhum chefe do executivo estadual e municipal. Ressalto também que Garotinho deixou o PDT durante o seu mandato como governador, se transferindo para o PMDB.

Os sucessivos reveses impostos a Brizola desde 1994, trouxeram várias percepções acerca do ex-governador, como também do próprio brizolismo. Para muitos o "caudilho" era a imagem de um político ultrapassado, com um discurso anacrônico e que não soube acompanhar as diferentes tendências pelas quais passavam a política brasileira e mundial. Portanto, para muitos, o brizolismo teria uma morte anunciada, junto do trabalhismo e do nacional-desenvolvimentismo, que se tornou uma pauta “démodé” durante a década de 1990.

Apesar dos discursos e narrativas criadas em torno da figura de Brizola e das ideias e programas defendidas pelo mesmo, acredito que seus ideais políticos se fazem presentes na cena da política do Rio de Janeiro, principalmente em seu epicentro, a "Cidade Maravilhosa", seja em programas com plataformas e políticas

\footnotetext{
${ }^{1}$ É interessante analisar as derrotas sofridas por Brizola e seus candidatos. No ano de 1992, a candidata para prefeitura Cidinha Campos (PDT) foi derrotada por César Maia (PMDB), ex-aliado e Secretário de Fazenda de Brizola, em 1982. No ano de 1996 a vitória foi de Luiz Paulo Conde, afilhado político de César Maia. No ano de 1994, nova derrota do PDT, também para um antigo aliado, Marcelo Allencar, que venceu Anthony Garotinho (PDT).
} 
públicas de inspiração ou releitura do brizolismo, como também entre os críticos, que veem nesse movimento político, a gênese de todas as mazelas que o espaço carioca e fluminense atravessam ao longo dos últimos quarenta anos.

Para o bem ou para o mal, Brizola e o brizolismo fazem parte da política da cidade e do estado do Rio de Janeiro, tendo nesses espaços seu ponto e contraponto, que se retroalimentam em uma dialética, em que as manifestações tanto do brizolismo quanto do antibrizolismo se exprimem através de argumentos antagônicos.

Esse movimento, aparentemente contraditório, que fez parte do jogo político, instaurado, principalmente na metrópole carioca, foi um dos elementos mais sedutores que me aproximaram do brizolismo e do seu campo de ações. Isso não significa que não haja críticas de minha parte às administrações pedetistas e, também à atuação de Brizola. Observei, porém, nas suas políticas públicas a possibilidade de mudanças efetivas em alguns campos, como na educação com o Programa Especial de Educação e seu principal expoente, os Centros Integrados de Educação Pública (CIEPs) e na habitação, com o projeto de regularização fundiária e urbanização de favelas. Outra política relevante, e também em um ponto muito sensível do brizolismo, foi na área de segurança pública, que apesar de todas as críticas tinham a finalidade de tornar o trabalho policial, não como um oposto aos anseios comunitários, mas sim de uma sinergia que possibilitasse a atuação humanizada das forças policiais envolvidas diretamente nos ambientes mais vulneráveis como as favelas e periferias.

Além das políticas mencionadas, pude, no meu cotidiano, observar outras que marcaram a gestão pedetista no Rio de Janeiro. Dentre elas destaco os mutirões comunitários. Esse programa visava melhorar as condições de vida nas favelas, dotando as mesmas de infraestrutura. Um dado interessante quanto a essa iniciativa política era a adesão dos moradores, como mão de obra e partícipe do planejamento das ações que seriam realizadas. Esse foi um exemplo de política pública em que houve aquiescência das associações de moradores e de lideranças políticas locais.

Diante do exposto, faz-se importante observar algumas indagações relevantes com a finalidade de concluir a tese, como por exemplo: o que estou argumentando com a tese, ou seja, qual é a sua questão norteadora? Afirmo que o 
principal questionamento que procuro responder é que o brizolismo, enquanto fenômeno político, tem seu principal espaço de representação não no estado do Rio de Janeiro, mas sim em sua capital, dada a visibilidade que a metrópole carioca "emprestou" a esse movimento político. Portanto, o recorte espacial e territorial que delimitei para análise é a metrópole carioca.

Observo o brizolismo como uma das representações da cidade do Rio de Janeiro, através de um processo de ancoragem neste espaço, que pode ser interpretado a partir de categorias e imagens tanto positivas quanto negativas, o que gerou sentidos e percepções distintas em relação ao fenômeno brizolismo.

A minha análise acerca do brizolismo tem como recorte temporal o início da década de 1980, tendo seu marco fundamental nas eleições para o governo do estado do Rio de Janeiro em 1982. Isso não significa que os pleitos eleitorais posteriores, como as eleições presidenciais de 1989 e a campanha vitoriosa de 1990, não tenham sido importantes, porém no segundo sufrágio, de 1990, o brizolismo já era um fenômeno consolidado nessa unidade da federação, o oposto de $1982 \mathrm{em}$ que Brizola teve que enfrentar uma máquina política já sedimentada nos territórios carioca e fluminense.

Nas eleições de 1990, Brizola tornou-se um fenômeno eleitoral em todo estado, sua vitória nesse ano, após as eleições presidenciais de 1989, deu-se em primeiro turno com mais de $60 \%$ dos votos válidos, ainda muito influenciada pelas políticas públicas de seu primeiro mandato e, também pela tentativa de conquistar o principal cargo do executivo nacional ${ }^{2}$.

Procuro afirmar que o brizolismo foi consolidado enquanto movimento e não como uma doutrina política, a partir da primeira campanha de Brizola para o governo do estado do Rio de Janeiro.

A partir da questão norteadora, afirmo que o brizolismo, foi um fenômeno político mais carioca que fluminense. Parto da hipótese de que o brizolismo é um

\footnotetext{
${ }^{2}$ Uma análise deve ser feita quanto a derrota de Brizola nas eleições presidenciais de 1989. Quando Brizola e o PDT resolveram dar apoio a Lula (PT), houve uma das maiores transferências de votos de um político para outro. Cerca de $78 \%$ dos votos de Brizola migraram para o candidato petista, no estado do Rio de Janeiro e no Rio Grande do Sul. Isso é um indicador de força do brizolismo e de Brizola em seus redutos eleitorais.
} 
movimento político que teve sua tessitura, prática ou teórica, formada no Rio de Janeiro, a partir do retorno de Brizola ao Brasil em 1979 e a escolha da Cidade Maravilhosa como domicílio eleitoral.

Para sustentar o que foi mencionado, procuro salientar alguns questionamentos que permitiram confirmar o que estou querendo elucidar com minha hipótese, que é exatamente: Como o brizolismo conseguiu ter no Rio de Janeiro o seu espaço de visibilidade ou de aparição? De que modo isso foi conseguido?

Como resposta a primeira indagação, temos a visão de que o Rio de Janeiro, em um determinado período histórico sempre foi caracterizado como um espaço de viés oposicionista. Além disso, Brizola enfatizava que era um dos únicos, senão o único candidato que realmente fazia oposição ao governo federal. Outro aspecto relevante foi a capitalidade (AZEVEDO 2016, MOTTA, 2000, OSÓRIO, 2015), da qual o Rio de Janeiro é dotado. Para Brizola e os brizolistas, a metrópole carioca continuava sendo a "caixa de ressonância do Brasil" (MOTTA, 2000) e o "tambor político do país", portanto era compreensível a escolha de Brizola pela Cidade Maravilhosa ao invés de sua terra natal.

O segundo questionamento poderá ser elucidado tendo em vista as políticas públicas realizadas durante o primeiro governo de Brizola à frente do estado do Rio de Janeiro. As ações realizadas durante o primeiro mandato foram uma tentativa de ascender ao governo federal. Porém, algumas dessas políticas ganharam mais evidência que outras, se tornando marcas que alcançaram projeção nacional e alçou Brizola a condição de candidato de renome nacional. Dentre elas, podem ser destacados os Centros Integrados de Educação Pública, os CIEPs, popularmente conhecidos como "Brizolões".

No terceiro ponto, concluo que o brizolismo enquanto fenômeno político carioca, apesar de todas as suas contradições surgidas a partir de seus defensores e detratores, continua sendo parte do imaginário político carioca, concretizado através de discursos tanto pró ou contra, ou seja, brizolismo e antibrizolismo. Outro aspecto interessante foi a adoção de políticas públicas, realizadas por políticos que não eram vinculados ao brizolismo, mas que tinham influências brizolistas. Como exemplo, podemos citar, recentemente, durante a gestão do prefeito Eduardo Paes 
a criação das Escolas do Amanhã, que se aproximava dos CIEPs e ações realizadas por Marcelo Crivella, com a criação do "Cimento Social”, correlacionado a políticas participativas como o Mutirão Comunitário.

Quanto aos procedimentos metodológicos, parto de uma análise qualitativa, pois almejo um enfoque maior na interpretação do objeto a ser pesquisado. Dessa forma, o contexto histórico e econômico, se torna relevante para entender o surgimento do fenômeno do brizolismo no Brasil, em particular, no Rio de Janeiro. Essa análise foi fundamental na realização da pesquisa e também para a conclusão da tese. No caso do fenômeno pesquisado há uma relação subjetiva entre o objeto pesquisado e o pesquisador, como meio de compreender e interpretar experiências para explicar o mesmo, o que não significa que seus resultados sejam meramente de apreensões pessoais, pois partem também de uma fundamentação teórica que corroborou para sua análise.

Os capítulos seguiram bases teóricas distintas, de acordo com o tema abordado em cada um deles. No primeiro capítulo que trata do retorno de Brizola, no contexto da abertura política e na reorganização do sistema partidário, utilizo como interlocutores principais Sento-Sé (1999) sobre o retorno de Brizola e sua reinserção na cena política brasileira após o processo de abertura política. Quanto a questão da distensão do regime e do fim do bipartidarismo foram referendados Diniz (2016), Baloyra (1988), Selcher (1988), Bresser-Pererira (1985), Fleischer (1988). Aprecio também a questão do trabalhismo no Rio de Janeiro, seguindo o seu documento fundador, a Carta de Lisboa, um dos pilares das políticas públicas brizolistas. Além disso, analiso a formação do Partido Democrático Trabalhista (PDT) e sua inserção na política do estado do Rio de Janeiro.

No segundo capítulo a temática principal foi voltada para a capitalidade e a centralidade da cidade do Rio de Janeiro e sua importância para visibilidade política do projeto brizolista. Outro aspecto importante abordado foi a formação de bases e territórios políticos, bem como a mudança do quadro político e institucional nos espaços carioca e fluminense. Sobre a capitalidade do Rio de Janeiro, os principais interlocutores foram os seguintes autores Azevedo (2011), Motta (2016) e Osório (2016). Procuro desenvolver um conceito de capitalidade em que o brizolismo foi um dos elementos que permitiu uma nova visibilidade política para a metrópole 
carioca. Quanto às eleições de 1982 e à competição contra as máquinas de voto chaguista e amaralista que dominavam o quadro político e institucional, as principais colaborações foram de Fleischer (1988), Selcher (1985), Lamounier (1982) e Diniz (1982). Quanto à formação de bases e territórios eleitorais (Castro, 2007, 2013 e 2015), Lima, Fraga e Silva (2014), Sento-Sé (1999) e Terron (2012).

No terceiro capítulo, procuro evidenciar o papel da cidade do Rio de Janeiro enquanto vitrine para o brizolismo, ou seja, o que permitiu a visibilidade desse movimento político com reconhecimento nacional. Como bases teóricas para o capítulo, utilizei Berque (1998), com seus conceitos sobre paisagens marca e matriz e Sack (1986), com seu desenvolvimento sobre o conceito de territorialidade em que um determinado grupo detém o poder sobre uma área. Abordo também a liderança carismática de Brizola, tendo como principal interlocutor Weber (1980). Exploro também o conceito de representações sociais, balizados em autores como Jodelet (1988), Jovchelovitch (2000) e Moscovici (2009). Por último, realizei uma análise do brizolismo como instrumento socioespacial, através de símbolos e representações que são feitas a partir de suas políticas.

No quarto capítulo abordo a apropriação da Cinelândia, que ficou conhecida pelos brizolistas como Brizolândia. Para entender esse espaço de percepção do brizolismo no Rio de Janeiro, foi necessário se valer do conceito de espaço público. Como contribuições fundamentais para embasar a análise sobre a apropriação do espaço pelos brizolistas, temos: Arendt (2020), Narcizo (2009), Serpa (2004), Indovina (2002) e Gomes (2002). Outro conceito importante foi o de espaço político. Para sua análise vários autores contribuíram de forma significativa para, bem como para articular esse conceito com o de espaço público Downs (1957), Castro (2017), Bucci (2016) Gomes (2012) e Arendt (2020). 


\section{O retorno do 'caudilho' à cena política brasileira: a formação do Partido Democrático Trabalhista (PDT) na redemocratização do país}

\subsection{Antecedentes}

No dia 22 de janeiro de 1922, nasceu Leonel de Moura Brizola, filho de agricultores de origem italiana, em Cruzinha, Distrito de Carazinho, que está localizado no município de Passo Fundo. O pai, um maragato, foi morto na Revolução de $1923^{3}$.

Sua carreira política iniciou quando ainda era estudante de engenharia, participando da fundação do Partido Trabalhista Brasileiro (PTB) gaúcho no ano de 1945. Em 1946 candidatou-se para Assembleia estadual, sendo eleito em janeiro de 1947, pelo Rio Grande do Sul.

No ano de 1950 elegeu-se Deputado Federal pelo PTB/RS e dois anos depois foi convidado pelo Governador Ernesto Dornelles para assumir a Secretaria de Obras. Em 1954 elegeu-se novamente Deputado Federal pelo PTB/RS e deixou o mandato para disputar as eleições sendo eleito prefeito de Porto Alegre em 1955.

Em 1958, foi eleito governador do Rio Grande do Sul, pelo PTB. Durante sua administração foram tomadas algumas iniciativas relevantes em campos diversos da administração pública, dentre elas a construção de mais de 5000 escolas.

No ano de 1961, após a renúncia de Jânio Quadros, Brizola liderou a Campanha da Legalidade, com a finalidade de impedir a concretização de um golpe institucional, para assegurar a posse de João Goulart como presidente da República. Nessa campanha, a rádio Guaíba se instalou dentro do Palácio Piratini, em Porto Alegre, de onde difundiu seu sinal por diversas localidades do território nacional. Essa rede de rádios ficou conhecida como Cadeia da Legalidade. No Rio de Janeiro,

\footnotetext{
${ }^{3}$ A Revolução de 1923 ocorreu no Rio Grande do Sul onde havia disputa entre dois campos, de um lado, os partidários do presidente Borges de Medeiros, chamados de Borgistas ou Ximangos (lenços brancos), e de outro os revolucionários aliados de Joaquim Francisco de Assis Brasil, os Assistas ou Maragatos (lenços vermelhos).
} 
a rádio Mayrink Veiga foi responsável por reproduzir o sinal. Dessa forma, Brizola ganhou visibilidade em todo o país.

Aproveitando essa repercussão, e procurando se aproximar mais do centro decisório nacional, no ano de 1962, Brizola, elegeu-se Deputado Federal (PTB/RJ) pelo estado da Guanabara, tendo uma votação expressiva de cerca de 300 mil votos, superando um dos seus principais rivais na política, Carlos Lacerda. (CARRION Jr, 1989)

No ano de 1964, no entanto, Brizola teve seus direitos políticos cassados pelo regime que entrou em vigor no país, sob a argumentação de que suas ações eram geradoras de instabilidade no país e representavam perigo à segurança nacional. Além de sua esperada resistência à destituição de Jango, repetindo a Cadeia da Legalidade, suas ações, quando governador do Rio Grande do Sul, eram consideradas incendiárias e traziam constrangimentos para o país como foi no episódio de nacionalização de duas empresas americanas ${ }^{4}$.

\subsection{Da transição controlada à abertura: novos pactos políticos e a redemocratização}

A transição para a democracia foi realizada num período relativamente longo, marcado por uma contradição entre forças de conservação que não queriam mudanças aceleradas no regime e pressões no sentido de uma abertura política com o restabelecimento da democracia no país.

Vários fatores contribuíram para o processo. Entre eles a modificação da estrutura da população brasileira, cada vez mais urbana; as derrotas eleitorais que o regime sofreu em eleições proporcionais; a desaceleração do crescimento econômico; o ressurgimento dos movimentos sociais, o fim do pacto político do empresariado nacional com o governo militar. Esses fatores enfraqueceram o regime que perdeu parte do seu apoio, desencadeando o processo de abertura promovido pelo próprio governo. (FLEISCHER, p.147)

\footnotetext{
${ }^{4} \mathrm{Na}$ sua gestão, como governador do Rio Grande do Sul, Brizola encampou duas empresas americanas, a Bond and Share, do setor de energia e a ITT do setor de comunicação. Essas duas ações de seu governo geraram questões diplomáticas do governo brasileiro com o americano
} 
O processo de abertura e redemocratização foi controlado pelo regime vigente. Segundo Diniz (2016), a partir do Governo Geisel (1974-1979), iniciou-se um movimento cíclico de uma liberalização controlada pelo regime dirigente, comprometida, antes de tudo, com a contenção do ritmo de mudança dentro de limites toleráveis pelo sistema (p.239). A eleição de 1974 foi importante para o processo de abertura, porque o Movimento Democrático Brasileiro (MDB) elegeu dezesseis do total de vinte e quatro senadores, além de $44 \%$ das cadeiras da Câmara (FLEISCHER, p.145). Outra questão igualmente importante foi o fim da luta armada com a desarticulação da guerrilha urbana e rural e, também, a diminuição do apoio do empresariado ligado ao capital industrial tanto nacional quanto internacional.

Baloyra (1988), sobre esse período, afirma que o processo de distensão “objetivava frear a deterioração sofrida pelo governo Médici (1969-1974) e para impedir que o colapso do regime resultasse do confronto dos militares da 'linha dura' ou domínio do processo pela oposição”. (p.48)

Como podemos observar diversos fatores influenciaram no processo de abertura do regime, aqueles de natureza econômica como o fim do 'milagre' e pressões do empresariado nacional para que o governo estabelecesse políticas mais favoráveis ao mercado interno; o de natureza política com a vitória da oposição nas eleições proporcionais de 1974 - já comentada - e o fim de células terroristas e da luta armada, o que já não justificava a utilização de um aparato repressor. (BRESSER PEREIRA, p. 25)

A abertura, portanto, foi fruto de um processo de negociação. No caso da abertura através de negociação, as mudanças políticas estiveram sob o controle dos militares que estavam no poder, e dessa forma seria possível uma transição com menos riscos.

Sobre esse assunto, Share e Mainwaring (1988):

A democracia implica a possibilidade de alternância no poder. Nesse sentido, a transição para a democracia envolve muito mais que a liberalização do regime autoritário. A liberalização referese a um declínio da repressão e ao restabelecimento dos direitos civis e políticos essenciais, sem, no entanto, permitir eleições competitivas que admitiriam a alternância no poder. As 
transições rumo à democracia envolvem tanto a liberalização $0^{5}$ como a democratização. (p.236)

Dessa forma temos aquilo que Mainwaring e Viola (1988) chamam de uma "transição pelo alto", em que todo processo é comandado pela classe dirigente, no caso brasileiro pelo próprio regime militar. No entanto, essa transição foi negociada, tanto no espectro da situação quanto da oposição, representada pelo MDB.

Share e Mainwaring (1998) após analisarem os processos de transição, concluíram que as transições não seguem um modelo unificado. Os autores tipificaram três modalidades gerais de transição, que demonstramos no esquema 1:

Esquema 1: Modelos de transição

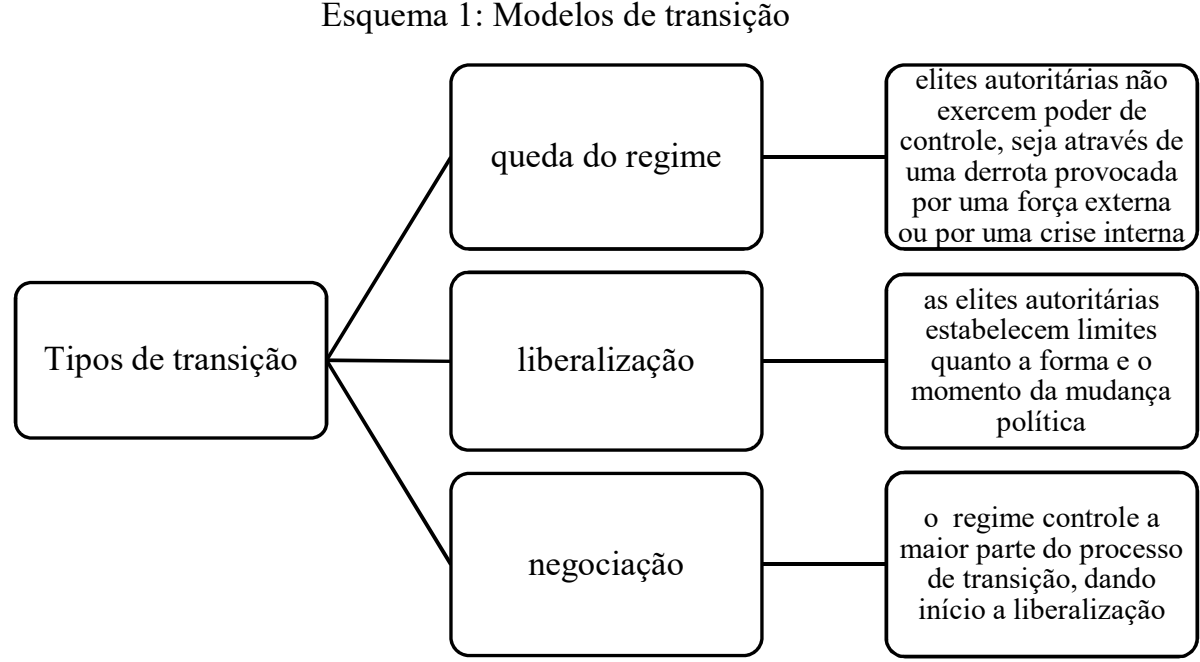

Fonte: Elaborado pelo autor a partir de Share e Mainwaring (1998), 2020.

Analisando o esquema, é possível confirmar que o caso brasileiro está relacionado ao tipo de transição por negociação, pois todo o processo, no seu período inicial, foi realizado e pensado pelo regime com a intenção de afastar setores da sociedade relacionados à mobilização das massas como operários e sindicatos, além de elementos mais à esquerda do cenário político-ideológico. A

\footnotetext{
${ }^{5}$ Segundo Packenham (1988, p. 201) as ideias liberais sofreram um duplo revés no Brasil. Por um lado estão associadas ao elitismo e à exploração capitalista. Por outro lado estão também associadas às teorias sobre "desenvolvimento" e "modernização" dos anos 1950 e 60, desacreditadas pelo golpe de 1964 e outros acontecimentos. Como resultado, o próprio termo "liberal" é um termo viciado e ambíguo no discurso político brasileiro e, como também na América Latina e na maioria dos países da Europa Ocidental. Para boa parte da esquerda brasileira, o liberalismo é considerado ao mesmo tempo antidemocrático e antinacionalista. Para Wanderley Guilherme dos Santos o liberalismo político não foi uma condição suficiente para democratização do poder, mas uma condição necessária.
} 
classe dirigente, com isso, não perdeu o controle sobre o processo, que poderia trazer efeitos políticos tanto na mobilização da população como também em determinados segmentos das Forças Armadas, contrários ao processo de abertura do regime.

De acordo com Selcher (1988, p. 20):

\begin{abstract}
Nesse meio tempo, a princípio sob o rótulo de "democracia relativa", casuísmos passaram a ser usados pragmaticamente para dividir e amortizar o avanço da oposição, minimizar o espontâneo e inesperado, e diluir os extremistas de (...) direita e esquerda. Para manter o espaço de manobra e o processo de longo prazo com um equilíbrio precário, o regime várias vezes julgou necessário resistir às exigências alternadas dos "linhas duras" e reformistas, dentro e fora do governo. As medidas de liberalização eram alternadas de medidas de consolidação, numa metáfora de sístole e diástole.
\end{abstract}

A metáfora da sístole e diástole foi converge ao momento que o regime estava passando, saindo de um período de maior repressão do período Médici e de questionamentos em relação à política econômica do período do "milagre". Além disso, como já citado, a derrota nas eleições legislativas fez com que o governo repensasse suas estratégias políticas. Essa metáfora nos mostra momentos importantes no ciclo de abertura em que o regime buscava amenizar sua imagem e suas práticas, através de ações políticas pontuais que demonstrassem uma democracia relativa ${ }^{6}$, num movimento de diástole, mas ao mesmo tempo não abrindo mão de mecanismos que inviabilizassem uma penetração maior da oposição nas regras colocadas para abertura política, fazendo a outra parte do ciclo, o movimento de sístole. Essa caracterização do período de abertura se deve às medidas institucionais tomadas pelo regime, ora com medidas consideradas democráticas, através da negociação com setores da sociedade civil, ora com medidas autoritárias.

\footnotetext{
${ }^{6} \mathrm{O}$ regime buscava dessa forma, ter mais legitimidade perante os diferentes segmentos da população, inclusive fazia com que a oposição, que já fazia parte da base legislativa, permitisse maior governabilidade do regime, através de medidas, mesmo como a "conta gotas", liberalizantes. É importante também mostrar que era relevante para o chamado Grupo do Planalto, controlar a chamada 'linha dura', por isso a utilização da metáfora de sístole e diástole.
} 
No plano político, o governo ainda tomou medidas de cunho eleitoral para tentar minimizar as perdas nesse campo. Após as eleições de 1974, a Lei Falcão ${ }^{7}$ (Lei 6339/76), elaborada para atuar nas eleições municipais do mesmo ano, tinha como principal objetivo, limitar a propaganda política no rádio e na televisão. Outra iniciativa do governo Geisel dentro da citada metáfora foi o chamado Pacote de $\mathrm{Abril}^{8}$, de 1977, uma medida tomada pelo governo, mais uma vez com o objetivo de estancar o crescimento da oposição. Dentre as providências contidas nessa política governamental temos a criação da eleição indireta para $1 / 3$ dos senadores, que foram denominados de senadores "biônicos" e, também o pleito indireto para governadores.

As novas regras eleitorais estabelecidas não significavam que haveria impedimento em relação à mudança do quadro político e institucional brasileiro, mas sim que o governo não queria deixar escapar do seu controle o papel de grande patrocinador do mesmo, pois isso amenizava a imagem perante a opinião pública para um possível processo de democratização da política brasileira.

O processo de abertura pode ser observado a partir de uma dicotomia entre a pressão social e a iniciativa do próprio Estado. Uma vez retirado de cena os movimentos de guerrilha, o regime passou a abrir canais de diálogo com instâncias representativas da sociedade.

Como bem observa Lafer (1984):

É no jogo entre, de um lado, a resistência "ex parti populi", e o esforço "ex parti principis", de manter o poder através de novos modelos de comportamento, que reside a explicação para as modificações que ocorreram nas regras, procedimentos e mecanismos necessários do sistema político brasileiro, que

\footnotetext{
${ }^{7}$ A Lei Falcão proibia os candidatos de falar na televisão, sendo permitida somente fotos com suas imagens e a exibição de seus currículos políticos. A Lei criada pelo ministro da Justiça Armando Falcão, tinha como principal objetivo frear o avanço da oposição, no caso capitaneada pelo MDB (Movimento Democrático Brasileiro)

${ }^{8} \mathrm{O}$ Pacote de Abril tinha como principal finalidade fazer com que o partido situacionista, a ARENA não sofresse derrota nas eleições de 1978. Dentre algumas medidas que comprovam essa afirmação temos a ampliação das bancadas que representavam os estados menos desenvolvidos, nos quais a ARENA costumava obter bons resultados eleitorais. Fonte: www.cpdoc.fgv.br. Acessado em: 21/09/2020.

${ }^{9}$ A expressão senadores "biônicos" foi criada pela bancada oposicionista que foram escolhidos a partir da mudança das regras eleitorais criadas pelo chamado Pacote de Abril de 1977.
} 
exprimem nesse sentido, a interação entre governantes e governados. (p.84)

Dentre as instâncias representativas da sociedade teve especial destaque os sindicatos e associações de classe empresarial brasileira. Coube ao governo a condução do processo de transição, não menos importante foi o papel do capital industrial no mesmo. A partir do rompimento do pacto político firmado entre esse setor e a tecnoburocracia estatal militar do regime (BRESSER-PEREIRA, 1985) a classe empresarial passou a representar um grupo de grande poder no sentido da democratização (DINIZ, 1982).

$\mathrm{Na}$ visão da elite empresarial com um viés liberalizante em relação à economia, o regime começou a ruir por alguns fatores importantes, como a derrota eleitoral no pleito de 1974, a intervenção do Estado na economia e o apoio do mesmo para o capital estrangeiro. Como bem observa Diniz (1982), "o alvo imediato das críticas formuladas pelo empresariado seria a expansão acelerada da intervenção do Estado no domínio econômico, implicando não só o alargamento do seu poder regulador, mas também a ampliação de suas funções empresariais” (p. $115)$.

O fortalecimento do papel do Estado gerou críticas do setor empresarial, mais sob o aspecto político do que econômico, pois o aumento das funções do Estado como grande empresário nacional tirava do setor privado o seu protagonismo e o alijava de seu papel interlocutor junto aos círculos dirigentes da cúpula militar.

O fim desse pacto gerou uma nova situação política no Brasil e, dessa forma, colocou o regime em cheque. A partir desse momento, o setor empresarial passou a apoiar o processo de redemocratização do país, no mesmo sentido, embora de forma não unificada, com o novo sindicalismo, as comunidades eclesiais de base, os movimentos de estudantes e intelectuais no processo. Assim, se por um lado o poder das classes empresariais deu legitimidade ao regime, por outro o fim do pacto entre essa classe e os militares gerou outro pacto pela redemocratização. Com isso, o processo que antes se verificava como abertura controlada, ganha novos contornos transformando-se num processo de redemocratização mais amplo, pela 
quantidade de atores envolvidos, incluindo outros que emergiram no cenário político brasileiro.

Outro fator que influenciou o processo de redemocratização foram as eleições de 1978, em que mesmo com todos os dispositivos criados pelo governo militar para frear uma escalada maior da oposição, garantiram maioria ao MDB. Uma das causas que teriam levado a esse novo quadro político-eleitoral foi a mudança no perfil da população com o aumento da população urbana brasileira vivendo em grandes centros, justamente onde o partido oposicionista elegeu a maioria para o senado federal. (BALOYRA, p.54)

Houve uma tendência de aumento da oposição nas regiões de maiores aglomerações urbanas, onde o crescimento da pobreza era mais intenso, não somente nas grandes cidades como também nas regiões metropolitanas, frente à crise econômica provocada pela grande carestia que se vislumbrava no período.

De acordo com Fleischer (1988):

Em termos nacionais, em 1978 a Arena começou a receber as maiorias dos votos apenas nas cidades de menos de cem mil habitantes, numa proporção inversa - maior número de votos, menor o tamanho do município. No Sudeste e no Sul, a Arena ia mal, recebendo, cerca de $38 \%$ e $51 \%$ dos votos respectivamente e, maioria apenas em cidades de menos de $5^{\circ}$ mil habitantes. A proporção inversa era visível em todas as regiões. Essa tendência era menos pronunciada nas duas regiões mais subdesenvolvidas, rurais e menos urbanizadas, o Norte e o Nordeste, onde a Arena conseguiu $61 \%$ e $72 \%$ dos votos respectivamente. (p.147)

A eleição de 1978 se tornou um “divisor de águas", abrindo caminhos para o processo de abertura que seguiu no governo Figueiredo. Dentre as mudanças mais vultosas estavam a anistia política, o fim do ato Institucional $\mathrm{n}^{0} 5$, do Ato Institucional $\mathrm{n}^{\mathrm{0}} 2$, sepultando o bipartidarismo e a reforma partidária ${ }^{10}$, além das eleições diretas para governador.

\footnotetext{
${ }^{10} \mathrm{~A}$ reforma partidária era vista como uma questão estratégica, principalmente para o ministro da Casa Civil, o general Golbery do Couto e Silva. Para ele o fator principal era fragmentar a oposição. De acordo com Baloyra (1988, p. 84), a fragmentação do MDB iria dificultar a cristalização de uma coalizão nacional que unisse nacionalistas militares, facções dissidentes da burguesia do período e elementos da classe média e operária.
} 
Nesse contexto, foi permitida a libertação de presos políticos e o retorno dos exilados, dentre eles Leonel de Moura Brizola, marcando o retorno do "caudilho" à cena política brasileira, patenteando o Rio de Janeiro como epicentro do brizolismo no Brasil.

\subsection{O retorno de Brizola}

Brizola permaneceu no exílio por 15 anos, tendo morado no Uruguai (19641977), Estados Unidos (1977-1978) e, por último, em Lisboa (1978-1979). No ano, de 1978, no entanto, o governo Brasileiro dá início ao processo de redemocratização. Segundo Sento Sé (1999), nesse ano, o governo autorizou a emissão de passaportes de entrada para brasileiros refugiados e exilados em outros países. "Remonta, portanto, a 1978, o processo lento e gradual de retorno ao Brasil de lideranças, ex-dirigentes e militantes que se encontravam no exterior" (p. 53). O mesmo autor acrescenta, contudo, que havia uma lista de passaportes proibidos, elaborada pelo governo, coibindo o retorno de alguns exilados. Entre eles estava o nome de Leonel Brizola ${ }^{11}$.

Portanto, para o regime militar vigente a figura de Brizola despertava desconfiança quanto à sua possível atuação na política brasileira, caso fosse anistiado e tivesse a permissão de retornar ao país. As palavras de Sento-Sé (1999) corroboram esta afirmação:

Ao discursar ali, Brizola reitera seu lugar na sucessão do fundador do trabalhismo, criador da legislação trabalhista, líder popular ou, nas palavras do próprio Brizola, "homem cuja vida pública foi o centro de tudo o que ocorreu de mais importante com nosso povo e o Brasil neste século XX”. (p.56)

Apesar da desconfiança, dentro do contexto de abertura política, fim dos Atos Institucionais, e anistia para aos exilados, Brizola retornou ao país no dia sete de setembro de $1979^{12}$.

\footnotetext{
${ }^{11}$ Além de Brizola, temos Luís Carlos Prestes, Francisco Julião, Miguel Arraes, Paulo Freire, Paulo Schilling, Marcio Moreira Alves e Gregório Bezerra,

${ }^{12}$ Quanto ao retorno de Brizola e à desconfiança que surgia em torno de sua figura é interessante destacar a declaração de Antonio Carlos Magalhães: Quem quer que chegue com outros propósitos que não sejam o de paz e harmonia, mais uma vez irá enganar-se com a disposição do povo brasileiro de progresso com paz social, abominando a violência e a desordem. Ao comentar as ameaças feitas
} 
Em seu primeiro ato político no país após o retorno do exílio, Brizola visitou os túmulos de Getúlio Vargas e João Goulart, ambos na cidade de São Borja-RS onde fez o seu primeiro discurso pós-obtenção dos seus direitos políticos. Essa visita aos dois presidentes teve importância simbólica, por serem as referências históricas mais importantes do trabalhismo brasileiro. Com esse ato, Brizola reafirmava seu comprometimento político com as lutas que defendia antes de 1964, buscando reconstruir a narrativa que dava sustentação a sua liderança política.

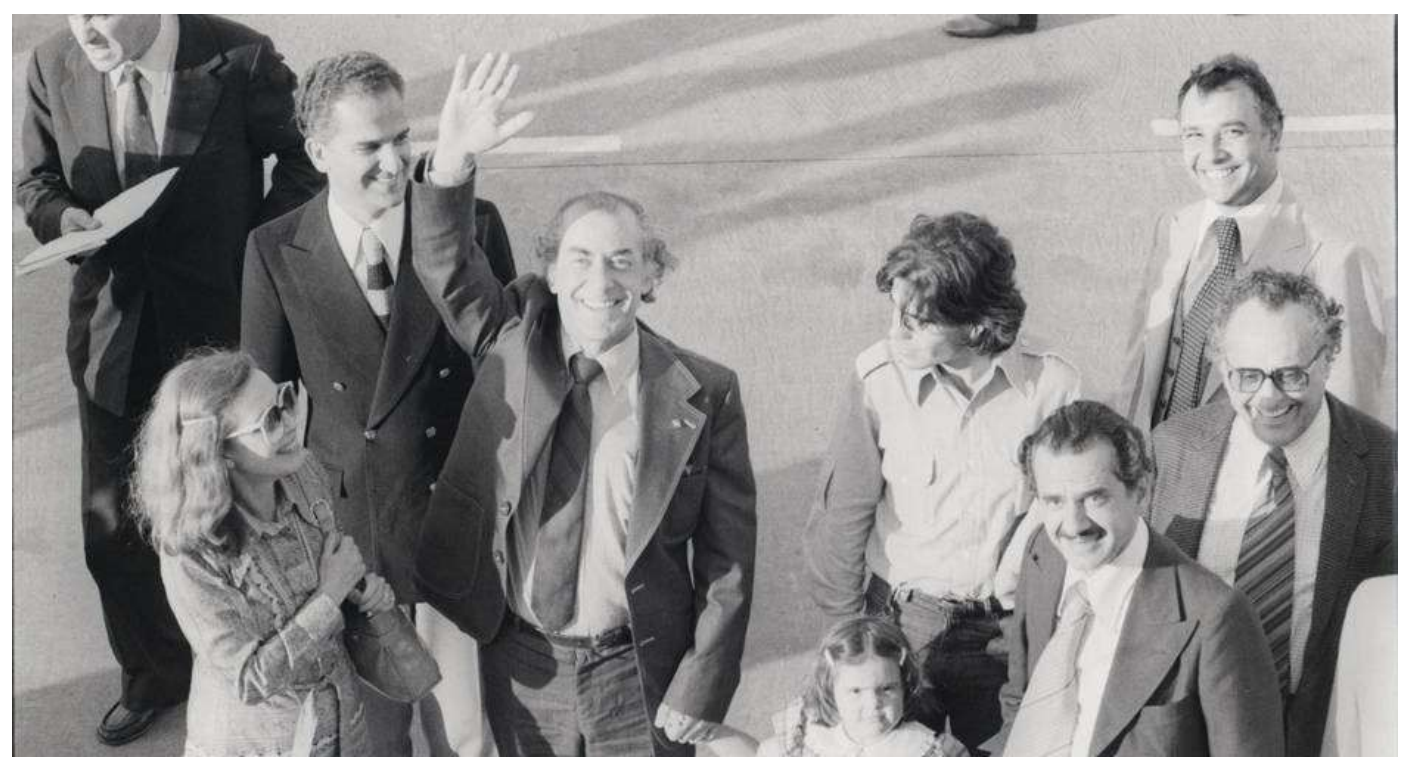

Imagem 1: Retorno de Brizola ao Brasil. Fonte: oglobo.globo.com. Acessado em: 26/09/2020

\subsection{O retorno à vida política no Rio de Janeiro e a perda da legenda do Partido Trabalhista Brasileiro (PTB)}

"Vi um homem chorar porque lhe negaram o direito de usar três letras do alfabeto para fins políticos. Vi uma mulher beber champanha porque lhes deram esse direito negado ao outro”. Carlos Drummond de Andrade.

Em outubro de 1979, Brizola mudou-se para o Rio de Janeiro com a principal finalidade de reconstruir sua vida política, pois via na metrópole carioca,

a Brizola pelo CCC (Comando de Caça aos Comunistas), disse Antônio Carlos: - Qualquer radicalismo é prejudicial e merece também a nossa repulsa. Entendo que deve haver observação e nunca provocação. Só os que não têm nenhuma visão poderão admitir à volta ao período anterior a Revolução de 1964 (O GLOBO, 07 de setembro de 1979). 
antiga capital da república, a possibilidade de projetar-se nacionalmente, abrindo caminho para o seu maior desejo e objetivo: o de ser presidente da República.

O ex-governador gaúcho já sabia da importância política e simbólica do Rio de Janeiro como espaço político de projeção nacional, pois no ano de 1962 foi eleito deputado federal pela Guanabara com mais de 300 mil votos, a maior votação alcançada até aquele momento por um parlamentar na história brasileira (LEITE FILHO, 2008). A 'capitalidade' que continuou marcando a "Cidade Maravilhosa", mesmo após a perda da condição de sede da República, era vista como uma possibilidade de dar maior projeção nacional para um político que almejava o cargo de chefe do executivo nacional.

É possível afirmar que Brizola tinha um projeto político próprio, estruturado durante o exílio. No período que morou em Portugal, agregou novas concepções ao seu pensamento e na sua conduta política ao manter contatos com membros da socialdemocracia europeia, quando foi gestado o fundamento do que seria posteriormente chamado de "novo trabalhismo".

A reforma partidária de 1979, realizada pelo governo militar, tinha como um de seus principais objetivos, enfraquecer a oposição através de sua fragmentação e com isso acabar com seu caráter plebiscitário, um dos objetivos do ministro da Casa Civil General Golbery do Couto e Silva, prevendo a dissolução dos dois grandes partidos políticos do período de exceção, Arena e MDB, e a criação de novas legendas partidárias ${ }^{13}$. Selcher (1985) argumenta que: "a intenção primária do governo era dividir o Movimento Democrático Brasileiro (MDB) em vários partidos menos expressivos, por meio de rupturas tanto na ala da esquerda como na direita. Por outro lado, foram elaboradas regras para a organização partidária (quatro ou cinco partidos) em vez de um número inoperável de pequenos partidos". (p.92)

No entanto, como argumenta Sarmento (2008, p.45), o projeto de regulamentação político partidário e do próprio calendário eleitoral seria orientado pela capacidade das forças políticas aliadas ao governo de criar condições para

\footnotetext{
${ }^{13}$ Sarmento (2008) defende que: a proposta previa imediata dissolução das duas legendas criadas a partir do AI-2 em 1965, flexibilizava as regras para criação de novas legendas, no entanto impedia a regularização de partidos com "ideologias subversivas".
} 
vencer as disputas eleitorais sem correr riscos de derrotas. Assim buscava-se forjar as condições para que o partido situacionista não sofresse, em 1982, os mesmos reveses políticos ocorridos em 1974 e 1978.

O MDB, por seu lado, buscou manter-se como bloco e fortalecer-se convidando para seus quadros o maior número possível de retornados do exílio. Brizola fazia parte dessa lista. No entanto, o "caudilho" almejava recuperar o 'fio da história', reorganizando o Partido Trabalhista Brasileiro (PTB), do qual foi um dos fundadores no Rio Grande do Sul. Essa reorganização seria realizada a partir do Rio de Janeiro, compreendido como centralidade e com capacidade de irradiação política no território nacional.

\section{Como afirma Sento-Sé (1999):}

Brizola defende a formação de uma frente ampla de partidos oposicionistas, independentes entre si. Crítica também o elitismo político, tanto de esquerda quanto de direita, afirmando a necessidade de que nos "sintamos encharcados de povo". Desembarca no Rio de Janeiro criticando o chaguismo, mas não poupa críticas igualmente duras aos movimentos de rearticulação do trabalhismo que, no seu entender, careciam de "molho sindical". Além disso, mostra boa assimilação à agenda social democrata europeia, em que alude repetidamente a questão das minorias. (p.88)

Brizola intencionava reorganizar o PTB nacionalmente com o propósito de disputar a presidência da República. O "caudilho" se via como o grande herdeiro do partido, por suas ligações políticas com trabalhistas históricos como Alberto Pasqualini, Getúlio Vargas e João Goulart. No entanto, encontrou oposição aos seus objetivos em Ivete Vargas, sobrinha neta de Getúlio Vargas, que também disputava o controle da legenda. (LEITE FILHO, 2008)

Os dois buscaram trâmites políticos distintos para obter o controle da sigla. Brizola se via como herdeiro direto devido sua trajetória política no período em que esteve no executivo e no legislativo e pela sua história no partido. Como argumentado por Sento-Sé (1999), Brizola contava com a "memória política nacional”, ou seja, com o chamado 'fio da história' que reconhecia nele o herdeiro último do PTB, aquele caracterizado pelas reformas de base, da aproximação com outros grupos de esquerda e do nacionalismo. 
Com relação à Ivete Vargas, esta não apresentava a mesma tradição e papel na estrutura político-partidário da legenda. A sobrinha de Getúlio, segundo vasta bibliografia sobre o tema, como Sento-Sé (1999), Leite Filho (2008), Moniz Bandeira e Aguiar (1991), valeu-se de outros mecanismos como a proximidade de relação com o general Golbery do Couto e Silva, um dos principais responsáveis pela reforma partidária de 1979, para conseguir seu objetivo, a posse da legenda.

Todo o período de indefinição em relação a quem manteria o partido foi extremamente prejudicial a Brizola, dificultando a composição política de uma nova legenda partidária para colocar em prática o "novo trabalhismo". Ao final da disputa, a o PTB ficou com Ivete Vargas.

Com a perda da sigla houve indefinições quanto aos rumos de um novo partido trabalhista e algumas lideranças petebistas decidiram permanecer no antigo partido ao lado de Ivete Vargas, enquanto outros migraram para a legenda oposicionista que já estava consolidada, o Partido da Mobilização Democrática Nacional (PMDB).

Segundo Sento-Sé (1999):

A indefinição quanto a quem caberia a nova legenda aumentou as dificuldades de arregimentação de lideranças e colaboradores. Muitos aliados potenciais do grupo de Brizola optaram por migrar para o recém-criado PP ou mesmo para o PMDB. (p.95)

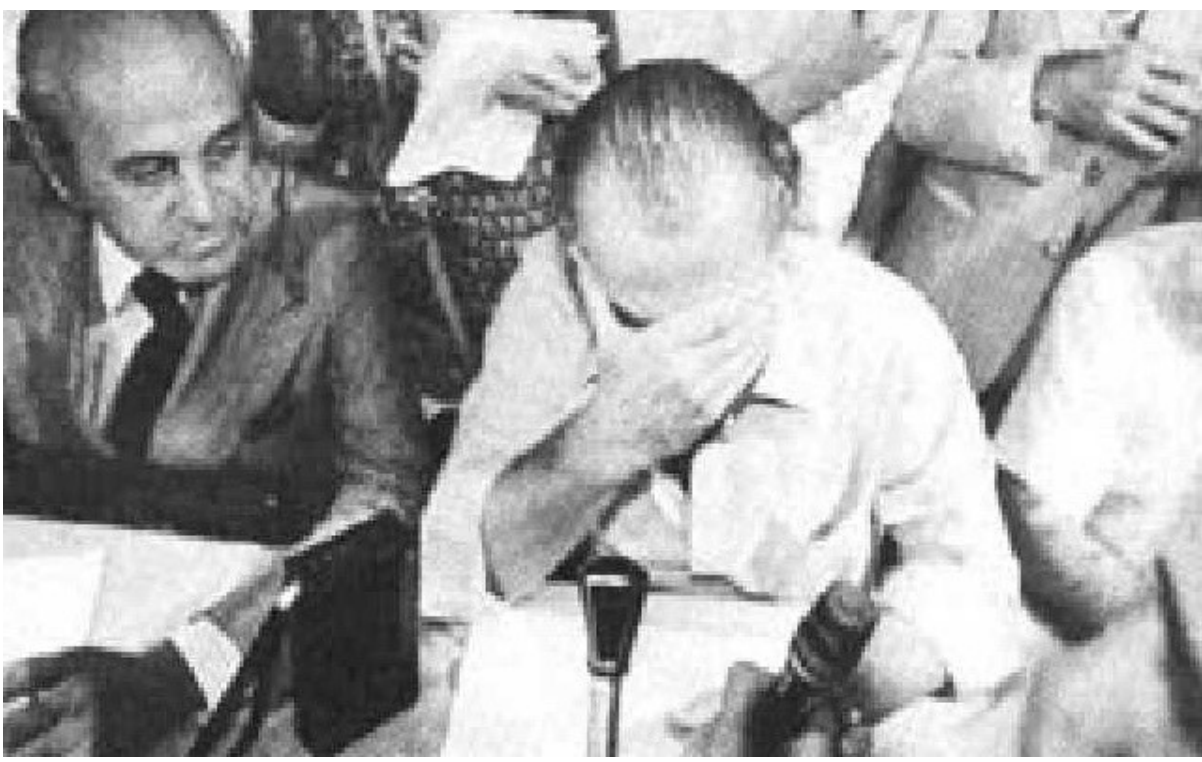

Imagem 2: A perda do PTB.

Fonte: www.pdt.org.br. Acessado em: 25/09/2020. 


\subsection{O Trabalhismo varguista, uma das bases fundadoras do 'novo trabalhismo'}

Entender as propostas políticas de Leonel Brizola após a abertura política requer um exercício histórico, já que durante o período em que esteve no exílio, sua pretensão era a de reorganizar o Partido Trabalhista Brasileiro (PTB) e colocar em prática a bandeira do trabalhismo ressignificado pela Carta de Lisboa de 1979.

O trabalhismo proposto pelo documento elaborado na capital portuguesa, apesar de trazer elementos presentes do trabalhismo pré-1964, como o nacionalismo e o reformismo, encampava outros conceitos oriundos da aproximação de Brizola com a socialdemocracia europeia e com a Internacional Socialista.

Para além de herdar o legado deixado por Getúlio Vargas e João Goulart, Brizola propunha refundar o trabalhismo pré-1964 em novas bases, retirando dele o caráter corporativista que se desenvolveu, principalmente, durante o período Vargas. A relação com os sindicatos durante o período varguista foi um dos motivos de desconfiança do novo movimento sindical que estava surgindo no Brasil, durante o período da abertura política ${ }^{14}$.

Assim, para entendermos melhor as transformações objetivadas por Brizola, se faz necessário compreendermos o que foi caracterizado como trabalhismo.

O trabalhismo surge durante o primeiro governo de Getúlio Vargas (1930 1945), mais definidamente a partir da constituição do Estado Novo (1937).

O ponto fundamental para o projeto varguista consistia na valorização do trabalho como um componente ético através do qual seriam formados os cidadãos. Essa valorização seria fundada na construção de uma identidade operária, amparada formalmente pelo Estado, por instrumentos como a carteira de trabalho, e na possibilidade de através deste ascender socialmente ${ }^{15}$.

\footnotetext{
${ }^{14}$ Freire, 1998. p.130, argumenta que Brizola teve grandes dificuldades em estabelecer alianças com o sindicalismo brasileiro, que passava por um processo de renovação de lideranças, com grande parte delas procurando se afirmar com base em um discurso de repúdio às práticas e a cultura do "velho sindicalismo", do qual o PTB varguista tinha sido a principal referência partidária.

${ }^{15}$ É importante frisar a formação do trabalhismo pré-64 e, particularmente sua feição corporativista, que vai ser observada pela relação do governo getulista com os sindicatos, porque no retorno de Brizola ao Brasil e no seu projeto trabalhista, conhecido como "Novo Trabalhismo", houve resistências de vários segmentos políticos, inclusive no chamado campo progressista, alguns que já
} 
Como observa Andrade, 1945:

O trabalho - outrora forma de escravidão - é hoje um meio de emancipação da personalidade, algo que valoriza o homem e o torna digno de respeito e da proteção da sociedade. Viver honestamente do trabalho (...), encontrar em seu próprio esforço esse sentido de utilidade social capaz de canalizá-lo para o bem comum - é o maior dever do cidadão e sua mais alta virtude no Estado moderno. (p.6)

Um mecanismo fundamental na política varguista foi a criação da legislação trabalhista. Com isso, ganhava força, a percepção de que a questão social deveria ser resolvida e a valorização do trabalho, dando a esse um viés positivo, como atividade primordial para formação do indivíduo em sua plenitude voltado para o bem comum. Compreendia-se, assim, o trabalhador como responsável pela realização de seu próprio destino, pois através do trabalho seria possível conseguir a proteção do Estado.

Como nos mostra Gomes (2005):

O valor fundamental do trabalho - como meio de ascensão social e não de saneamento moral - e a dignidade do trabalhador são o eixo em torno do qual se monta sua comunicação com a sociedade e com o mundo da política. O estatuto do trabalhador é o que dá identidade social e política ao homem brasileiro, fato magistralmente materializado pela carteira de trabalho e pela definição da vadiagem como crime. (p.27)

A proposta do trabalhismo varguista tinha como objetivo criar uma identidade social em que houve uma valorização do trabalho como um componente ético, pautado no nacionalismo e, contra uma figura emblemática no cotidiano brasileiro - o malandro - e através dele a formação cidadã. Além disso, o trabalhismo varguista tinha caráter corporativista, uma vez que buscou articular o sindicalismo aos partidos políticos que estavam surgindo, como foi o caso, principalmente do Partido Trabalhista Brasileiro (PTB), que teve em Getúlio Vargas um de seus criadores.

Com o varguismo, os sindicatos não tinham autonomia de ação, pois faziam parte da própria estrutura governamental, no sentido de formar o "cidadão-

existiam, como segmentos do MDB e dos comunistas e outros que estavam em formação, como o chamado "Novo Sindicalismo". 
trabalhador". Na concepção política do Estado Novo, deveria haver uma articulação entre o povo e as elites, levando em conta a questão social e tendo o Estado o seu fio condutor. (GOMES, 2005).

Esse novo processo histórico tinha como uma de suas características a formação da personalidade nacional, tendo, portanto, uma dimensão criadora, retomando fatores tradicionais em relação ao país, através de dois eixos identitários, a cultura e a natureza, que se apresentam como aspectos presentes no inconsciente nacional. Sobre isso Gomes (2005), afirma que:

\begin{abstract}
Restaurar a sociedade brasileira era retirá-la do estado da natureza, isto é, organizá-la por via do poder político. Tal ação implicava um retorno à própria cultura nacional - ao caráter do homem brasileiro. A tradição a ser encontrada e revivida seria a junção da natureza e da cultura por intervenção da política, que acionaria o elemento integrador e produtivo do trabalhador nacional. (p.195)
\end{abstract}

Outra faceta do governo estado-novista era sua preocupação com a produção de um estado de bem-estar social. Assim as questões sociais se tornaram preocupação do regime e passaram a ser encaradas como problemas do Estado, tornando-se uma importante distinção em face dos períodos anteriores aos anos 1930. Segundo Gomes (2005):

A revolução e principalmente o estabelecimento do Estado Novo distinguiram-se de todos os demais fatos de nossa história, na medida em que se afastavam das meras preocupações formais com procedimentos e modelos jurídicos, para mergulhar nas profundezas das nossas questões econômicas e sociais. (p.197)

No entanto, dentro do contexto político da política do Estado Novo, a questão da sindicalização era um dos temas mais relevantes para o projeto do trabalhismo varguista, juntamente com a Justiça do Trabalho e Previdência Social. Gomes (2005)

O projeto do governo Vargas a partir do Estado Novo era controlar a organização sindical, a partir colaboração com as lideranças sindicais. Para isso, foram criadas políticas públicas voltadas diretamente para o movimento sindical, como o Imposto Sindical, que tinha como finalidade dotar os sindicatos de recursos. Outra iniciativa importante foi a criação de uma Comissão Técnica de Orientação Sindical (CTOS), que tinha quatro objetivos, como promover o espírito sindical, 
divulgar a orientação governamental em relação aos sindicatos, promover cursos de administração sindical e prestar colaboração aos sindicatos (GOMES, 2005).

O governo brasileiro tinha a clara intenção de inserir o trabalhador na estrutura sindical uma vez que objetivava alinhar o corporativismo da classe trabalhadora com os interesses do Estado.

A discussão em torno das políticas varguistas que deram origem ao trabalhismo brasileiro consiste até o período pré-1964 e marcou um tipo de identificação da classe trabalhadora com o governo de forma subserviente. Por isso, a expressão 'populismo' se torna usual na classificação sobre as ligações entre governo e trabalhadores nesse período. No entanto, nos questionamos se podemos categorizar o trabalhismo petebista, como populista, com toda carga negativa que é estabelecida a esse termo, como subserviência, clientelismo e a visão dos trabalhadores como massa amorfa que é conduzida pelo Estado.

A questão que se levanta quanto ao populismo se apresenta com uma definição irresoluta, porque ao mesmo tempo pode levar a satisfação da classe trabalhadora como também ser uma forma de controle da mesma, como podemos observar na argumentação de Debert, 1979:

O populismo tem caráter ambíguo, constituindo a um só tempo manipulação e satisfação das classes populares. Surgiu e manteve-se como uma alternativa política viável enquanto foi capaz de satisfazer, de forma real, a aspectos de interesse das classes populares. (p.3)

Os sindicatos, nesse contexto, representavam um grande filão político para o Partido Trabalhista Brasileiro, porque eles serviam como possibilidade de angariar filiados para o novo partido que estava surgindo. Através do PTB seria possível ter um representante político-partidário que atuaria pelo direito dos trabalhadores. O partido já nasce, portanto, dentro do ideário corporativista do governo Vargas. Destarte, apresentava em sua origem uma característica carismática e personalista.

No entanto, sobre a atuação do Partido Trabalhista Brasileira (PTB), Batistela (2013), afirma que: 
O PTB elegeu os sindicatos como seu principal local de atuação, o objetivo do partido era atrair e mobilizar as camadas populares, principalmente nos grandes centros urbanos, para órbita do partido, apresentando-se como agremiação partidária que levaria os trabalhadores a alcançar seus direitos. No entanto, o PTB não foi criado para ser um partido dos trabalhadores, mas um 'partido para os trabalhadores'. (p.119)

Além da defesa do trabalhismo, o PTB tinha como característica marcante o seu viés nacionalista. Como bandeiras, temos a defesa dos interesses nacionais e no campo discursivo uma das questões levantadas era fazer do Brasil um país autônomo, através de uma política desenvolvimentista e da luta contra o imperialismo ${ }^{16}$.

Dentro do quadro político do PTB, dois grupos tornaram-se antagonistas e buscavam hegemonia da agremiação. Esses grupos, de acordo com Delgado (1989) eram, de um lado, o núcleo formado pelos getulistas, ou seja, mais fisiológico e pragmático, mais identificados com a personificação do líder e com a burocracia do Estado Novo e, de outro, os reformistas, que defendiam a ideia de que o PTB deveria se organizar sobre uma doutrina trabalhista socializante.

Essa segunda corrente tinha a influência expressiva de Alberto Pasqualini. Esse político gaúcho procurou dotar o trabalhismo de uma visão mais humanista, trazendo concepções da chamada doutrina social da igreja. Foi a partir da atuação de Pasqualini que o PTB nos anos 1960 passou a defender reformas sociais como pontos prioritários para emancipação da população brasileira e a melhoria de suas condições de vida.

Podemos observar, no esquema 2 , de forma sintetizada, as diferenças entre os dois grupos que formavam o PTB no período pré-1964.

\footnotetext{
${ }^{16}$ Uma das características presentes no discurso de Brizola e, posteriormente, entre os brizolistas, foi o nacionalismo e, também a defesa do anti-imperialismo. No campo econômico, Brizola sempre falava nas perdas internacionais, que deveriam ser contidas. Essas perdas, segundo ele, era um dos males que fazia do Brasil um país atrasado economicamente e com graves problemas sociais.
} 
Esquema 2: Grupos do Partido Trabalhista Brasileiro - pré 1964



Fonte: elaborado pelo autor, 2020, a partir de Delgado, 1989.

Conforme as palavras de Grijó (2007, p. 94):

Pasqualini foi o tradutor dos conteúdos da chamada doutrina social da igreja para as políticas partidárias inauguradas no Brasil após a queda do Estado Novo. A sua doutrina trabalhista apoiavase nas encíclicas Rerum Novarum (1891) e Quadragésimo Anno (1931), concebendo o trabalhismo como profundamente humano e essencialmente cristão.

Foi com esta base teórica/teológica cristã que Pasqualini propôs uma alternativa tanto para o capitalismo quanto para o socialismo, o chamado capitalismo solidarista ${ }^{17}$, próximo a socialdemocracia Fabiana, sem adesão ao marxismo. Esse modelo observava no Estado o papel de promover o bem-estar social. A partir dessa concepção, defendeu-se que o PTB, para, além de sua bandeira nacionalista, deveria voltar-se para reformas econômicas e sociais que pudessem de forma estrutural, melhorar as condições de vida da população e diminuir as injustiças sociais ${ }^{18}$.

As proposições de Pasqualini são importantes, porque tiveram ampla repercussão nas formulações de políticas reformistas no partido, bem como no

\footnotetext{
${ }^{17} \mathrm{~A}$ formulação do capitalismo solidarista de Pasqualini apresentava uma visão oposta tanto em relação ao capitalismo quanto ao socialismo. Nos dois casos, para o formulador desse pensamento, os dois sistemas são desumanos em relação aos trabalhadores, por isso propõe uma alternativa.

${ }^{18}$ No capitalismo solidarista de Pasqualini a propriedade privada é mantida e incentivada, onde a liberdade dos indivíduos é valorizada, mas uma e outra ordenadas pelo princípio da solidariedade e da ajuda mútua dos diversos atores e classes sociais. No capitalismo solidarista, o Estado tem papel fundamental. Cabe a ele arbitrar dissensos, corrigir iniquidades acentuadas e promover o equilíbrio e o bem estar sociais. (SENTO-SÉ, 1999, p. 182)
} 
pensamento político de Leonel Brizola, influenciando a ressignificação do trabalhismo a partir do retorno do "caudilho" a cena política brasileira. Essa ressignificação é evidenciada nos compromissos estabelecidos pela chamada Carta de Lisboa, de 1979.

Através desse breve histórico do trabalhismo brasileiro até o período pré1964 foi possível estabelecer o fio da história que vai ser retomado com o retorno do "caudilho" para o Brasil em 1979, e a revisão desse trabalhismo, quando Leonel Brizola lança as bases do chamado "Novo Trabalhismo".

\subsection{O "Novo Trabalhismo" e a "invenção do Brizolismo".}

Durante o período da Lei da Anistia (1979) havia muitas controvérsias entre os militares quanto ao retorno do "caudilho", levando em consideração seu passado de agitador político, tanto no período em que fez parte do executivo gaúcho, como prefeito e governador quanto no seu papel no legislativo ${ }^{19}$.

Foi a partir da eleição de 1962, que Brizola começou a construir sua base política no Rio de Janeiro. Em 1960, para o PTB, de acordo com Ferreira (1998) havia a necessidade de lançar uma candidatura à altura para enfrentar Lacerda e, para o partido trabalhista e, também para Brizola, essa era a oportunidade que se abria no cenário eleitoral brasileiro.

O enfrentamento a Carlos Lacerda na Guanabara apresentou grande relevância para Brizola, pois colocou em embate as duas principais forças políticas e partidárias do Brasil - PTB e UDN. Com votação expressiva alcançada na Guanabara superou Lacerda, o ex-governador gaúcho movimentou suas bases políticas para aquele que viria a ser o território do brizolismo no Brasil: a metrópole carioca.

\footnotetext{
${ }^{19}$ É importante salientar que antes da Lei da Anistia, no ano de 1978, o governo brasileiro emitiu passaportes de entrada no país pelas embaixadas brasileiras e países que tinham exilados. Havia, no entanto, uma lista elaborada pelo governo militar que proibia a emissão de passaportes e proibia o retorno de alguns exilados, dentre eles Leonel Brizola.
} 
Quinze anos depois, com seu retorno ao Rio de Janeiro, importa destacar um dos documentos norteadores do "Novo Trabalhismo" e da formação de um novo partido político, a Carta de Lisboa.

Conforme as palavras de Sento-Sé (1999):

Brizola retorna a atividade política como herdeiro legítimo da tradição trabalhista, continuador e realizador futuro da obra iniciada por Vargas. Notícias recentes o relacionam aos grandes estadistas europeus. Movimentando-se entre imagens, Brizola desembarca no Brasil e reinicia sua carreira pública, circulando entre a tradição (o trabalhismo) e a modernidade (a socialdemocracia de inspiração europeia). (p.48)

A reinserção de Brizola no cenário político brasileiro ${ }^{20}$ teve oposição de diferentes campos políticos, tanto dos militares que ainda tinham desconfiança do passado agitador, de empresários, devido ao forte discurso nacionalista e reformista, de antigos comunistas e, também de novos atores que surgiram durante o período de abertura patrocinado pelo regime, como por exemplo, o novo sindicalismo que estava sendo fundado no $\mathrm{ABC}$ paulista e resistiam à figura do ex-governador gaúcho, porque associavam a sua imagem ao "velho sindicalismo" e ao corporativismo petebista.

O trabalhismo petebista no período pré-1964, apesar de toda sua relação com os trabalhadores e com as questões sociais, sofreu inúmeras resistências de uma nova esquerda, originada a partir da abertura política: o "novo sindicalismo" Esse movimento político, observava o trabalhismo praticado pelo PTB como fisiológico e corporativista e, também 'peleguista'. Com isso, o retorno de Brizola na cena política brasileira e a criação de um novo partido trabalhista sofreram a antipatia de diversos segmentos políticos e movimentos sociais surgidos no Brasil, no final dos anos 1970 e início da década de 1980.

Apesar de recuperar bandeiras políticas do período pré-1964, como o nacionalismo e o reformismo, havia um aspecto inovador: o documento de Lisboa,

\footnotetext{
${ }^{20} \mathrm{Cabe}$ destacar outro aspecto relevante e significativo. Apesar de Brizola ser considerado pelos antigos trabalhistas como o herdeiro do legado de Vargas, havia resistências dentro dos quadros que faziam parte de sua aliança política, principalmente pelos janguistas. Os partidários do PTB, aliados de Jango conservavam uma lembrança negativa de Brizola com relação a Jango, pois muitas de suas ações foram consideradas prejudiciais ao seu governo.
} 
influenciado pela socialdemocracia europeia, que procurava dar atenção às minorias e massas marginalizadas.

O documento fundador do Partido Democrático Trabalhista (PDT) estabeleceu compromissos, atenções prioritárias e ações políticas, que foram importantes para o estabelecimento de políticas públicas, adotadas durante o período da gestão pedetista no Rio de Janeiro.

O novo trabalhismo referendado pela Carta de Lisboa unia elementos presentes no discurso trabalhista do período pré-1964, como o reformismo e o nacionalismo, mas ao mesmo tempo integra à sua discussão questões envolvendo negros, mulheres e indígenas. Apesar de todo viés modernizante e com nova coloração, o Novo Trabalhismo, ainda cultivava a presença do getulismo, pois continuava "firmemente, sob inspiração da Carta Testamento ${ }^{21}$ do presidente Getúlio Vargas, a caminhada junto ao povo que nos levará à emancipação da Pátria”. (CHACON, 1985)

Nos quadros a seguir, temos os principais pontos estabelecidos pela Carta de Lisboa, que fundamentaram as políticas públicas brizolistas no Rio de Janeiro.

Quadro 1: Compromissos da Carta de Lisboa

\begin{tabular}{|c|c|c|}
\hline \multicolumn{3}{|c|}{ Compromissos } \\
\hline $\begin{array}{l}\text { Reconduzir o Brasil a uma } \\
\text { institucionalidade } \\
\text { democrática em que todo } \\
\text { poder emane do povo e seja } \\
\text { por ele periodicamente } \\
\text { controlado através de } \\
\text { eleições livres e diretas. }\end{array}$ & $\begin{array}{l}\text { Levantar as bandeiras do } \\
\text { Trabalhismo } \\
\text { reimplantar a liberdade } \\
\text { sindical e o direito de } \\
\text { greve. }\end{array}$ & $\begin{array}{l}\text { Reverter as diretrizes da } \\
\text { política econômica, com o } \\
\text { objetivo de afirmar a } \\
\text { prioridade de dar satisfação às } \\
\text { necessidades vitais do povo, } \\
\text { como alimentação, saúde, } \\
\text { moradia, vestuário e educação. }\end{array}$ \\
\hline
\end{tabular}

Fonte: elaborado pelo autor (2021) a partir da Carta de Lisboa (1979)

\footnotetext{
${ }^{21}$ Segundo Sento-Sé (1999, p. 172): a formação do projeto pedagógico do nacionalismo brizolista encontra-se em três documentos exemplares - esse é o termo - que o norteiam e lhe conferem corpo ético, político e doutrinário. Remontam às origens afirmativamente, evocam a memória que deve ser celebrada. São três os textos, e todos eles têm a ver com a história do trabalhismo: a Carta Testamento de Vargas, a obra de Alberto Pasqualini e a Carta de Lisboa. O primeiro remonta as origens, testemunhando a virtude, a abnegação e os percalços. O segundo retoma o projeto original e o atualiza. As obras de Pasqualini funcionam como meio de ligação entre um e outro.
} 
Quadro 2: Atenções Prioritárias da Carta de Lisboa

\begin{tabular}{|c|c|c|}
\hline \multicolumn{3}{|c|}{ Atenções prioritárias } \\
\hline $\begin{array}{l}\text { Salvar crianças } \\
\text { abandonadas e famintas, } \\
\text { bem como os jovens que } \\
\text { alcançam os dezoito anos } \\
\text { analfabetos. }\end{array}$ & $\begin{array}{l}\text { Buscar formas mais } \\
\text { eficazes de faze justiça } \\
\text { aos negros e aos índios, } \\
\text { que além da exploração, } \\
\text { sofrem uma } \\
\text { discriminação racial e } \\
\text { étnica. }\end{array}$ & $\begin{array}{l}\text { Dar atenção às } \\
\text { reivindicações das } \\
\text { mulheres que jamais viu } \\
\text { seu direito reconhecido e } \\
\text { equiparado. }\end{array}$ \\
\hline
\end{tabular}

Fonte: elaborado pelo autor (2021) a partir da Carta de Lisboa (1979)

Quadro 3: Ações políticas presentes na Carta de Lisboa

\begin{tabular}{|l|l|}
\hline \multicolumn{2}{|c|}{ Ações Políticas } \\
\hline $\begin{array}{l}\text { A luta por uma Anistia ampla, geral e } \\
\text { irrestrita, requisito indispensável à } \\
\text { reunificação da comunidade nacional para } \\
\text { fazer do Brasil uma Pátria solidária de } \\
\text { cidadãos livres e emancipados do medo, } \\
\text { da ignorância e da penúria. }\end{array}$ & $\begin{array}{l}\text { que só se efetivara no Brasil quando } \\
\text { organização partidária o nosso povo }\end{array}$ \\
eleger a Assembleia Nacional \\
Constituinte.
\end{tabular}

Fonte: elaborado pelo autor (2021) a partir da Carta de Lisboa (1979)

Através do exposto pelos quadros, com elementos importantes estabelecidos pela Carta de Lisboa, foi possível perceber sua influência na formação do novo partido, o Partido Democrático Trabalhista (PDT), que segundo seu regimento tem como principal bandeira política a luta pelos marginalizados. Outro ponto importante do documento foi a influência exercida no primeiro ano do governo Brizola, como no Encontro de Mendes (1983), com a criação do Programa Especial de Educação, tendo como resultado principal os Centros Integrados de Educação Pública (CIEPs) e o Plano de Desenvolvimento Econômico e Social do estado do Rio de Janeiro. A partir dele foi gestada uma das principais políticas públicas do brizolismo, o projeto "Para Cada Família, um Lote", um programa de urbanização e o primeiro de regularização fundiária em áreas favelizadas. Esses programas são duas marcas importantes da gestão de Brizola como veremos no terceiro capítulo. 
A partir da fundação do que seriam as bases do Novo Trabalhismo, abordaremos a formação do novo partido, de bases trabalhistas e que tinha como pretensão ser um partido de massas, o Partido Democrático Trabalhista (PDT).

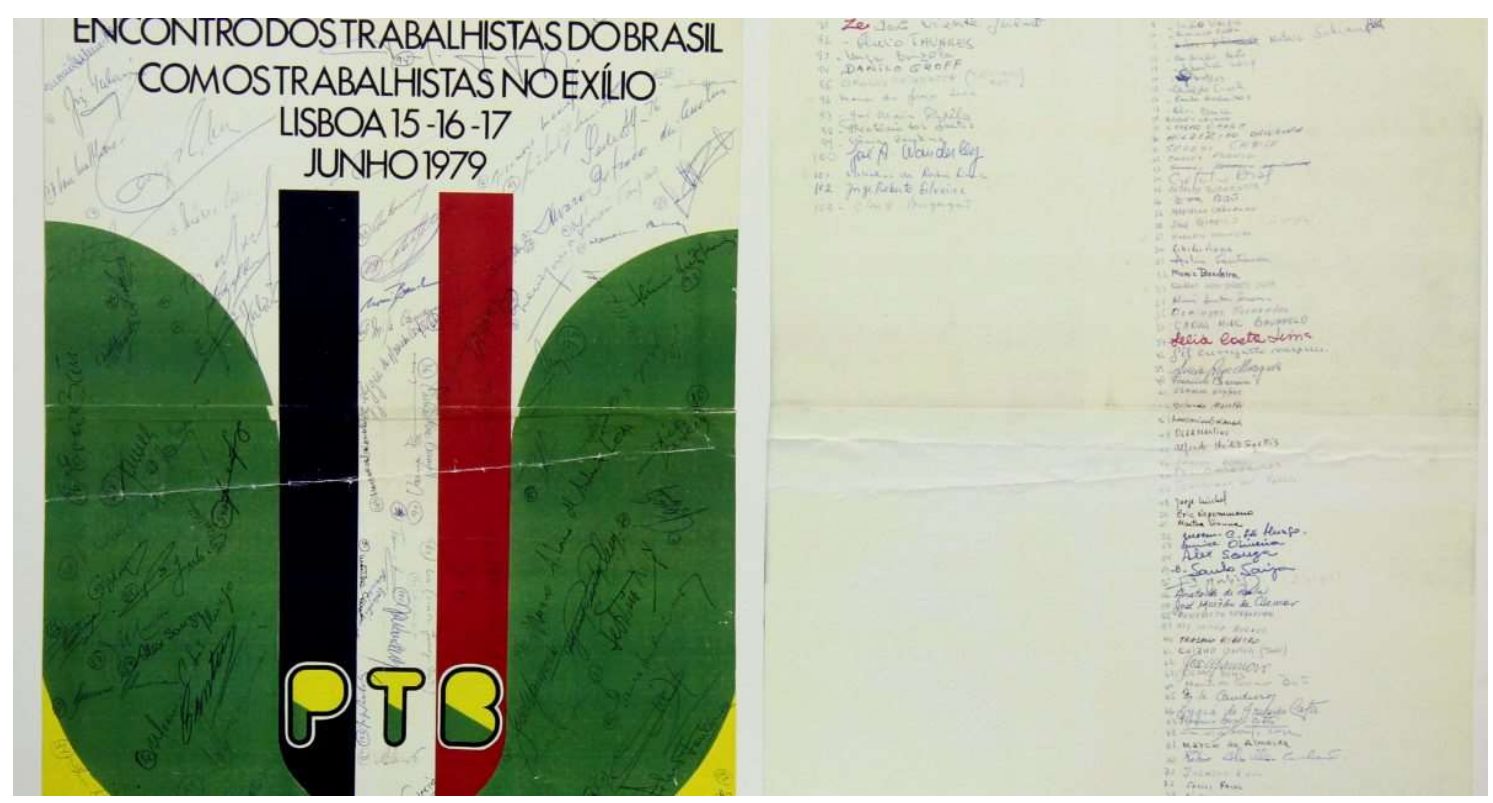

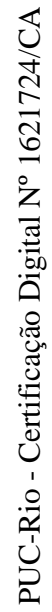

Imagem 3: Cartaz do Encontro de Lisboa de 1979. Encontros dos Trabalhistas do Brasil com os do exílio.

Fonte: www.pdt.org.br. Acessado em: 25/09/2020.

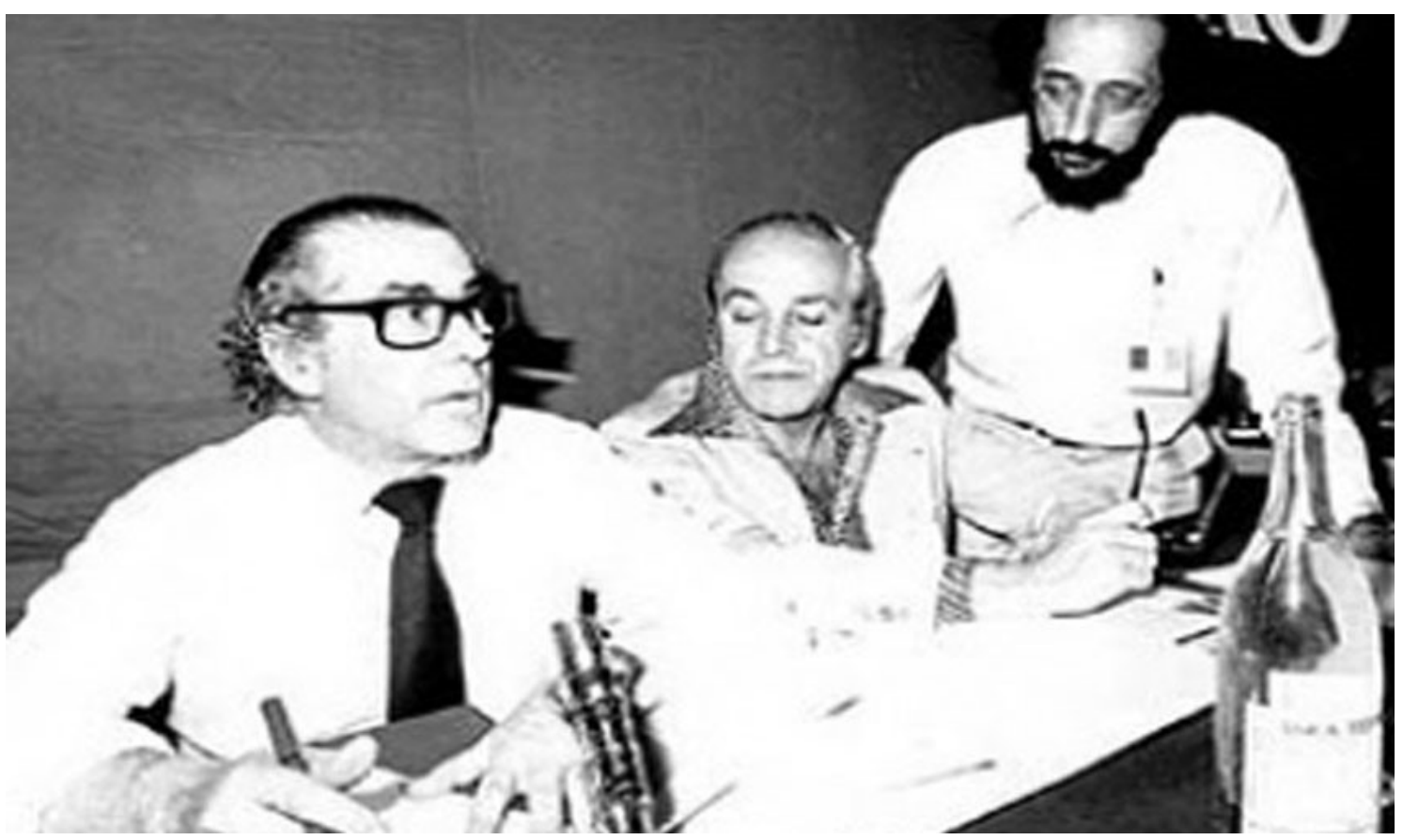

Imagem 4: Assinatura da Carta de Lisboa, 1979.

Fonte: www.pdt.org.br. Acessado em: 25/09/2020 
No esquema 3, apresento algumas características do trabalhismo e do novo trabalhismo.

Esquema 3: Trabalhismo e Novo Trabalhismo

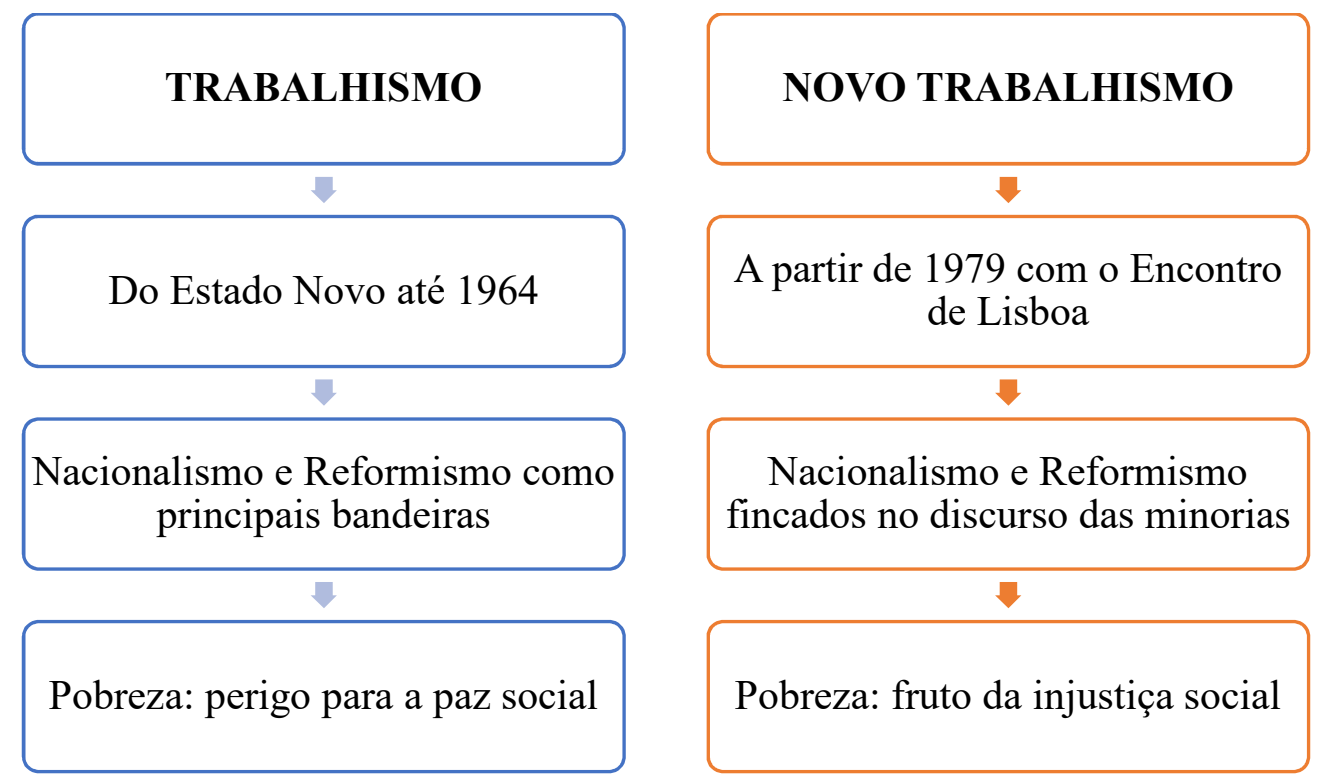

Fonte: elaborado pelo autor, 2020.

\subsection{A Criação do Partido Democrático Trabalhista (PDT)}

Com a perda da legenda do PTB, Brizola organizou nos dias 16 e 17 de maio de 1980, o Encontro Nacional dos Trabalhistas, realizado no Palácio Tiradentes (Assembleia Legislativa do Estado do Rio de Janeiro). O principal objetivo desse Encontro era a criação de um novo partido, que foi realizado no dia 26 de maio de 1980, quando foi fundado o Partido Democrático Trabalhista. Conforme o Estatuto do partido (2006):

O Partido Democrático Trabalhista (PDT) tem seus fundamentos na consciência democrática nacional e nas grandes lutas históricas do Trabalhismo brasileiro. Inspira-se na Declaração dos Direitos Humanos das Nações Unidas, no conteúdo da Carta Testamento do Presidente Getúlio Vargas e na Carta de Lisboa, elaborada quando se reuniram os trabalhistas no exílio com os trabalhistas que permaneceram no Brasil. (p.27)

Panebianco (2005) afirma que a construção de um partido político é complexo, sendo resultado da agremiação de uma pluralidade de grupos políticos distintos. Segundo o mesmo autor, o processo de criação de uma agremiação 
partidária é afetado pela difusão territorial, a presença ou não de uma organização patrocinadora e a presença ou ausência de uma liderança carismática.

O Partido Democrático Trabalhista, pela sua gênese, pode ser considerado um partido carismático, pois de acordo com D’Araújo (1996) “o PDT era o partido de Brizola e essa paternidade era mais importante que o nome oficial". (p.12). Novamente, Panebianco (2005), de acordo com o que se define como um partido carismático, afirma que "este pode ser identificado por ser formado por um líder que se coloca como idealizador e intérprete incontroverso de um conjunto de símbolos políticos que se tornam inseparáveis de sua pessoa".

O novo partido fundado por Brizola e já pensado durante o período do exílio tinha nele sua principal liderança e também o personagem histórico considerado herdeiro do trabalhismo de Getúlio Vargas e João Goulart. Portanto, diante do exposto, o carisma de Brizola foi um dos principais instrumentos de criação e de credibilidade da nova agremiação por aqueles que se filiaram ao mesmo.

O PDT tornava-se um partido que buscava manter o legado deixado pelo varguismo, através da reconstrução do trabalhismo pré-1964 e da questão dos direitos dos trabalhadores. Além disso, adotou como bandeira o resgate do pensamento reformista que ficou paralisado após o golpe militar, pois considerava que apenas através das reformas de base o Brasil poderia sair do atraso econômico e social e encontrar sua emancipação. (ESTATUTO DO PARTIDO DEMOCRÁTICO TRABALHISTA)

O PDT surgiu como um partido que mantinha um elo entre o presente e o passado, através da permanência de uma agenda reformista e com a incorporação de novos discursos como os direitos das minorias.

Sobre esse assunto de Sento-Sé (1999) afirma que:

O PDT surge, em 1980, como o único partido político que reclama um vínculo com o passado. É o partido da nostalgia, do fio da história que se tecia virtuosamente e foi rompido pelo arbítrio da força, do assassínio e da conspiração. (p.109)

O novo partido surgiu com um nome, considerado provisório, pois havia propostas de colocar algo que desse maior relevância a imbricada relação entre 
socialismo e trabalhismo ${ }^{22}$. Havia membros que queriam externar o socialismo na legenda, fato inteiramente rejeitado por Brizola. A resolução dessa questão se deu no Encontro de Mendes, que aconteceu no dia 23 de janeiro de 1983. A partir desse encontro foi elaborado um documento conhecido como Carta de Mendes, que traz a seguinte conclusão sobre o assunto:

Com relação à mudança na sigla do partido, como forma inclusive de expressar mais diretamente a índole socialista do partido, não constitui prioridade imediata e exige um processo de amadurecimento. (p.18)

Dentre alguns pontos do programa do Partido Democrático Trabalhista, podemos elencar alguns bem relevantes para a política brizolista, tais como:

- Compromisso com a nação e sua história pelo domínio de seu território e de suas riquezas capaz de afirmar sua soberania e sua independência;

- Educação como causa da salvação nacional, prioridade das prioridades: alimentar, acolher e assistir a todas as crianças do país;

- Salário justo para todos os trabalhadores, que têm o direito de ser os principais beneficiários, fruto do seu trabalho;

- Defesa do patrimônio público e das riquezas nacionais;

- Lutar pela causa da mulher, do negro, dos índios, dos jovens, dos idosos, de qualquer forma de discriminação;

- Reformular o sistema financeiro para torná-lo instrumento do desenvolvimento nacional. (ESTATUTO DO PARTIDO DEMOCRÁTICO TRABALHISTA)

O PDT de Leonel Brizola, apesar de incorporar as tradições do trabalhismo nacional-desenvolvimentista se apresentava como uma terceira via, através do trabalhismo socialista. Nesse projeto político, o partido deveria ser plural e vários grupos poderiam ser representados, fazer alianças com outros movimentos democráticos e progressistas; ou seja, a agremiação deveria ter como uma de suas características ser um 'partido de massa'.

\footnotetext{
${ }^{22}$ Dentro de alguns quadros presentes no partido, havia aqueles que queriam uma sigla que expressasse de forma mais explicita o viés socialista do partido, propunham a criação do PSDT (Partido Socialista Democrático Trabalhista), no entanto, o próprio Brizola se colocava bastante reticente a colocação do socialismo na legenda.
} 
Na conjuntura da formação do PDT, uma das marcas dos seus componentes e colaboradores deveria ser a diversidade, ou seja, um perfil partidário que não fazia parte da política tradicional ${ }^{23}$.

A questão do socialismo, presente na Carta de Lisboa, nunca foi de grande relevância para Brizola; o apelo à democracia era mais forte, até mesmo pelo período em que o Brasil estava atravessando, a abertura política. Esse fato pode ser evidenciado por uma manchete do Jornal do Brasil, mostrada a seguir, sobre a relevância do projeto de construção, ou melhor, de uma reconstrução da democracia brasileira, não somente nos seus aspectos formais de respeito e fortalecimento das instituições, mas também no seu viés social, que foi o alicerce para construção do chamado socialismo trabalhista, também conhecido como "socialismo moreno".

\section{Brizola prefere PDT a PTD porque T é mais forte que D}

Fonte: Jornal do Brasil, 27/05/1980

O "socialismo moreno" apresentava características que o diferiam dos movimentos socialistas presentes no Brasil. Podemos até mesmo afirmar que era um projeto antropofágico ${ }^{24}$, no sentido oswaldiano do termo, porque buscava um socialismo com características nacionais; portanto, não era a incorporação de teorias externalizadas, como é enfatizado pela própria Carta de Lisboa, e despido de soluções importadas, ou seja, o socialismo brizolista deveria 'ser mestiço', representando, de acordo com Darcy Ribeiro a diversidade presente na América Latina.

Sento-Sé (1999) sobre o socialismo moreno:

Seguindo a orientação de reconstituir valores contidos na Bildung ${ }^{25}$ brizolista, observamos os componentes simbólicos que vão configurar esse projeto. A questão a ser colocada é: como

\footnotetext{
${ }^{23}$ No PDT despontaram vários candidatos, além de lideranças ligadas ao movimento indígena e do movimento negro, como é o caso do cacique Juruna e também de Abdias do Nascimento, quanto ao ingresso de pessoas que não tinham uma relação com a política, pelo menos no momento da criação do PDT, podemos citar a entrada do cantor Agnaldo Timóteo.

${ }^{24}$ No movimento antropofágico criado por Oswald de Andrade havia a proposta de assimilar traços de outra cultura sem, no entanto, copiá-los. Essa característica vai ao encontro ao chamado "socialismo moreno" de Darcy Ribeiro quando este fala de uma civilização das Américas e buscava identidade nas raízes nacionais.

${ }^{25}$ De acordo com Sento-Sé (1999, p. 112) o bildung remete predominantemente, a conteúdos e processos de produção de conhecimento não especializados, ao corpo de símbolos e significações que constituem o patrimônio comum dos membros de uma mesma sociedade.
} 
seria o socialismo como orientação ideológica e pedagógica do brizolismo? Antes de tudo, ele deveria ser moreno. Ou seja, a adoção de modelos e experimentos de outros países deveria ser descartada. É necessária a adoção da cor local, e ela é mestiça. A alusão a cor deve ser encarada como algo mais que mero trocadilho ocasional. Afinal, é por ela, objeto de vergonha e humilhação no passado, que a singularidade da nação brasileira em sua rota para democracia socialista é realçada. Sejamos democráticos, socialistas e morenos. A "impureza" da raça garante a pureza do experimento. (p.112)

O Partido Democrático Trabalhista (PDT) surgia então como uma organização pluralista em que a principal bandeira a ser defendida era a democracia, vista por Brizola como o eixo fundamental para que o Novo Trabalhismo fosse consolidado, expressado através da incorporação de demandas dos movimentos sociais, da defesa dos direitos humanos, da defesa da tolerância e da alternância de poder através do voto. Além disso, sua preocupação não era somente com a questão institucional, mas também a 'democracia social'. O socialismo trabalhista só seria possível através de um regime democrático pleno e da emancipação a ser alcançada pelo país. Para tanto, o Brasil deveria superar a sua situação de dependência eliminando as suas 'perdas internacionais'.

O caminho para essa emancipação passava por um modelo de um socialismo com raízes nacionais em que a educação seria seu pilar fundamental. Essa bandeira esteve presente no discurso brizolista e pedetista ao longo do seu governo no Rio de Janeiro.

O fio da história estava estabelecido; passado e presente fizeram parte da construção da identidade do partido trabalhista, através do vínculo com o passado petebista pré-1964, ao mesmo tempo em que introduz um discurso modernizante trazido do contato com a socialdemocracia europeia.

Assim, o PDT nasceu no Rio de Janeiro, cidade na qual Brizola vai constituir seu domicílio eleitoral. E, apesar de ter no Rio Grande do Sul grande expressão política, foi na metrópole carioca que suas políticas públicas e o discurso brizolista ganharam mais força. A capitalidade do Rio de Janeiro e sua visão de "tambor político do Brasil", se tornaram o território da institucionalização do novo trabalhismo e do brizolismo para conseguir a projeção nacional de sua grande liderança, que observamos pelas políticas públicas realizadas em sua gestão como 
governador do estado durante dois mandatos e por movimentos políticos em torno do seu nome e de sua liderança política. 


\section{2. "Brizola na cabeça": capitalidade e poder local da Cidade Maravilhosa no jogo político nacional}

Desde que foi transformada em capital da colônia em 1763, a cidade do Rio de Janeiro apresenta forte centralidade no território brasileiro. Essa condição ganhou mais robustez com a chegada da Família Real Portuguesa, em 1808. Desde então, o espaço carioca iria aumentar suas funções administrativas no Brasil, tornando-se, posteriormente, a capital do império e da República brasileira. (MOTTA, 2000 e OSÓRIO, 2015)

A partir dessas condições institucionais de aspectos formais e informais ${ }^{26}$ a cidade passou a exercer a sua capitalidade. Apesar da perda da condição de capital, em 1960, os quase 200 anos de história como capital do Brasil certamente dotaram essa cidade de uma posição de centralidade política e cultural, capaz de fazer ressoar seus acontecimentos mais importantes e seu estilo de vida por todo o território nacional, embora com nuances geográficas e variações no tempo. Discutir a capitalidade do Rio de Janeiro, mesmo após a fissura no seu marco institucional, ou seja, a perda da condição de capital do Brasil em 1960 apresenta grande relevância, porque para algumas forças políticas a "Cidade Maravilhosa" continuava sendo o "tambor de ressonância” do Brasil. (MOTTA, 2000)

Dito isto, é possível compreender como para Brizola e para o brizolismo aqui considerado um 'movimento político', a metrópole carioca ganhou uma dimensão política e espacial de grande relevância para sua reentrada no jogo político, que possibilitariam a essas forças buscarem escalas territoriais e sociopolíticas e culturais mais amplas. Portanto, a percepção dessa manutenção da capitalidade política e cultural carioca foi um definidor do jogo político de Brizola, a partir da década de 1980, dadas as dimensões e a importância que para o líder trabalhista o espaço carioca tinha no epicentro da política nacional, dando visibilidade na escala do país às ações implementadas em seu governo no estado do Rio de Janeiro, caso fosse eleito.

\footnotetext{
${ }^{26}$ As condições de institucionalização aqui entendidas são baseadas em aspectos formais e informais, como bem definem economistas institucionalistas como North (1993), Hodgson (1997) e Veblen (1934) quando afirmam que as instituições podem ser definidas através de normas formais (leis e regulamentos) e informais (história, cultura, hábitos e rotinas).
} 
A relação local-nacional foi novamente trazida com o brizolismo para política do Rio de Janeiro, principalmente para o território carioca, porque a cidade, último domicílio eleitoral do líder trabalhista antes do exílio, ainda era vista como um fator de relevância para conseguir manter as bases de uma política que tivesse alcance nacional.

Através das considerações mencionadas anteriormente, vamos analisar, na primeira seção desse capítulo, as eleições de 1982, no estado do Rio de Janeiro, tendo em vista as forças políticas estabelecidas e a vitória de Brizola nessa unidade da federação, bem como os mecanismos que foram criados para que seu governo tivesse bases institucionais que permitissem a governabilidade do estado.

Por isso, vamos analisar também o jogo de forças que foi estabelecido na administração pública carioca e fluminense com a entrada do brizolismo, ocupando os espaços antes dominados pelas máquinas políticas do chaguismo e das articulações do amaralismo ${ }^{27}$. Como foi possível criar condições de governabilidade no novo estado do Rio de Janeiro, lembrando que essa unidade federada contava somente com sete anos após a fusão entre a Guanabara o antigo estado do Rio de Janeiro.

Na segunda seção, vamos elucidar a importância da capitalidade da cidade do Rio de Janeiro para o projeto brizolista e para as pretensões de Brizola em uma escala de âmbito nacional, que, através de seu governo, poderia trazer uma projeção que tornasse possível a disputa para o cargo do executivo nacional.

\footnotetext{
${ }^{27} \mathrm{O}$ Chaguismo se enraíza no Rio de Janeiro após a entrada de Chagas Freitas no governo do Estado da Guanabara. O Chaguismo segundo autores como Diniz (1982) e Sento-Sé (1999) estabeleceu uma política marcada pela prática do favorecimento, de clientelismo, através do atendimento de demandas específicas de seus eleitores. A relação com seu eleitorado não sofria a intermediação partidária, com isso teremos uma lógica subvertida na política em que o papel do poder executivo está colocado acima do legislativo, centralizando o poder naquele que controla a máquina política. O principal campo de atuação do chaguismo era na cidade do Rio de Janeiro, principalmente na zona oeste e, na periferia imediata da metrópole carioca, a Baixada Fluminense. O Amaralismo tem seu campo de atuação principalmente no interior do estado do Rio de Janeiro e, também em alguns municípios da Região Metropolitana, como é o caso de Niterói, a principal base do Amaralismo. Chagas Freitas e Amaral Peixoto eram duas lideranças políticas consolidadas e, de acordo com Costa (2009) os dois grupos passaram a ocupar o mesmo espaço, o MDB (Movimento Democrático Brasileiro) do Rio de Janeiro, após a fusão. Segundo esse autor a política amaralista era muito balizada nas articulações e não tinha o mesmo viés clientelista do seu adversário político.
} 
Neste capítulo, evidenciamos que o brizolismo ${ }^{28}$ identificado na cidade do Rio de Janeiro, soube aproveitar esse aspecto de 'capitalidade' remanescente ou ativo na "Cidade Maravilhosa", projetando na cena nacional suas políticas públicas mais importantes. Dentre elas podemos citar a construção e concepção dos Centros Integrados de Educação Pública (CIEPs) ${ }^{29}$.

As críticas à gestão Brizola no Rio de Janeiro também merecem destaque neste capítulo, pois a condição de capitalidade da cidade destacaram negativamente muitas políticas públicas implementadas durante os seus governos, no meio político e na imprensa nacional.

\subsection{Brizola "na cabeça": as eleições de 1982 no Rio de Janeiro}

\subsubsection{O contexto nacional nas eleições de 1982}

A eleição de 1982 foi a primeira que não teria um caráter plebiscitário, já que o jogo de forças não seria mais dado a partir do bipartidarismo polarizado pela ARENA e MDB, em vigor no país após o AI-2 de 1965. Com a reforma partidária de 1979, o AI-2 teve seu fim; no entanto, é relevante ressaltar que as estratégias de um processo de abertura lenta, gradual e segura também se fariam presentes durante o pleito eleitoral.

A reforma partidária de 1979 permitiu a possibilidade do retorno dos partidos políticos e dessa forma vários partidos foram fundados: o Partido Democrático Social (PDS), tem origem na ARENA, o Partido da Mobilização Democrática Nacional (PMDB) oriundo do MDB; o Partido Progressista (PP),

\footnotetext{
${ }^{28}$ Segundo Sento-Sé (1999), brizolista é o nome do discurso de atores políticos que fazem da adesão a Brizola, o princípio da identidade fundamental em sua inserção na esfera pública. Brizolismo é o nome do campo de embate de significações divergentes acerca da política brizolista. Ambos são, portanto, substantivos. O mesmo vale para antibrizolista.

${ }^{29}$ Os CIEPs (Centros Integrados de Educação Pública) podem ser considerados uma das principais políticas públicas do governo Brizola em suas duas gestões (1983-1987 e 1990-1994). A educação sempre foi uma bandeira política de Brizola que pode ser verificada no período em que foi governador do Rio Grande do Sul (1959-1962) com a construção de 5902 escolas (CARRION Jr, 1989). O programa dos CIEPs tinha relação com o Novo Trabalhismo construído em Lisboa, presente no seu documento fundador a Carta de Lisboa, quando afirma que devemos "salvar milhões de crianças abandonadas e famintas, bem como meio milhão de jovens que, anualmente, alcançam dezoito anos de idade analfabetos". De acordo com Bomeny, (1998) é "salvar pela educação".
} 
formado por dissidentes do MDB; o Partido Democrático Trabalhista (PDT), o Partido dos Trabalhadores (PT) e o Partido Trabalhista Brasileiro (PTB).

Apesar dos refluxos autoritários que foram observados no processo de abertura política, a estratégia governista foi eficiente com relação à fragmentação partidária da oposição e também teve o controle do processo de institucionalização de uma cultura partidária, tirando das forças oposicionistas essa iniciativa. Os novos partidos que surgiram nesse período teriam amplos campos de representação podendo gerar um efeito de maior aceitação na sociedade que reivindicava maior participação nas decisões políticas do país, mas, ao mesmo tempo, ficaria claro que o regime deveria controlar todo processo.

Além da reforma partidária, outra medida adotada pelo governo no processo de abertura foi o adiamento das eleições de 1979.

Segundo Lamounier (1980), o adiamento das eleições de 1979 para 1982, tendo como argumentos que "os novos partidos encontrariam dificuldades para organizar suas bases municipais, conforme exigências da lei, em tempo hábil para disputar as eleições" (p.125), acabavam por dar mais dois anos aos mandatos municipais de prefeitos e vereadores. $\mathrm{O}$ autor argumenta que isso era parte da estratégia situacionista para obter vantagens eleitorais a partir da construção de maior capilaridade, através do uso da máquina pública federal.

Até aquele início de década, somente três partidos conseguiriam formar diretórios locais. Todos os três eram herdeiros da estrutura do período militar: o PDS (oriundo da ARENA) e o PMDB e o PP (ambos oriundos do MDB). (LAMOUNIER, 1982).

Em novembro de 1981, o governo federal lançou mais um pacote de reformas eleitorais. Esse pacote trazia como novidades o voto vinculado, isto significa que o eleitor só podia votar em candidatos do mesmo partido político; a proibição de coligações partidárias; a obrigação dos partidos lançarem chapas completas, com candidatos a todos os cargos, criava um coeficiente eleitoral mínimo para o partido poder ter um candidato eleito. Esse pacote acabou por obrigar a fusão entre PP e PMDB, em fevereiro de 1982. 
Foi nesse contexto que se realizou o pleito eleitoral de 1982, o mais amplo do país desde as eleições de 1962. Esse sufrágio tinham grande significado político, pois em face das derrotas em eleições proporcionais anteriores, como 1974 e 1978, a popularidade do regime seria avaliada. Bresser Pereira (1985) argumenta que, em busca de manter maior popularidade, o governo passa a realizar mudanças no plano social, "definindo uma nova forma de populismo autoritário" (p.121). Dentre as medidas tomadas pelo governo para melhorar sua imagem perante a sociedade civil, Bresser Pereira (1985) destaca: o aumento do salário mínimo, a titulação de terras a posseiros, subsídios agrícolas e aumento do investimento em habitação e eletrificação no campo e nas cidades.

Nessa conjuntura, que Brizola se apresentou no debate eleitoral do Rio de Janeiro como o candidato de oposição ao regime vigente através de denúncias e da exposição da situação econômica brasileira.

Como resultado do pleito de 1982, o partido da situação, PDS elegeu a maioria dos governadores, mas em termos relativos pode-se dizer que sofreu uma derrota relativa, uma vez que a oposição ganhou nos principais estados brasileiros. (FLEISCHER, 1988)

Quanto às eleições municipais, adiadas de 1979 para 1982 mais uma vez, observamos os dois partidos majoritários com a maior parte dos municípios brasileiros. Numericamente, o PDS, partido governista, obteve o maior número de prefeituras e, no cômputo geral, o maior número de vereadores. (SELCHER, 1985)

No entanto, o PMDB conseguiu 75\% das cem maiores cidades do Brasil. A vitória da oposição nos centros urbanos evidenciava uma clivagem espacial observada na política brasileira: oposição dominando as grandes cidades e a situação controlando as menores, cujas bases econômicas ainda eram bastante ruralizadas.

A vitória da oposição fez com que o poder de barganha dos grupos não situacionistas aumentasse, principalmente com relação à possibilidade das eleições para presidente, que ocorreria somente no ano de 1985. Ou seja, a situação eleitoral abriu espaço para que a oposição participasse do processo decisório da sucessão presidencial. 
De acordo com as palavras de Selcher (1985):

Os resultados das eleições emprestaram apoio e visibilidade à estratégia da oposição de forçar negociações mais amplas, ao mostrar ao governo que não podia governar e controlar a sucessão, sozinho e ao incentivar o diálogo com todos os setores da oposição para as políticas nacionais importantes, modificação da Constituição e escolha do novo presidente. Ficou então estabelecido o cenário para política de coalizão, reformas institucionais mais amplas e um candidato civil para presidente. (p.105)

Tal situação relacionada ao estado do Rio de Janeiro, no seu escopo local e regional, afetou o equilíbrio das máquinas eleitorais do chaguismo e do amaralismo para a conquista dos territórios carioca e fluminense, a partir da década de 1980.

\subsubsection{O Rio de Janeiro nas eleições de 1982: Brizola contra as máquinas de voto}

As eleições no Rio de Janeiro representaram um grande desafio para Brizola e para o recém-fundado Partido Democrático Trabalhista (PDT). Primeiramente, devido às dificuldades colocadas pelo próprio regime para os partidos recémformados e, em segundo lugar pelo fato de que tanto o estado do Rio de Janeiro quanto à antiga Guanabara eram redutos políticos de forças oposicionistas ${ }^{30} \mathrm{a}$ Brizola.

É importante trazer a recordação de que o estado da Guanabara, constituído a partir da transferência da capital para Brasília, perdurou até 1975, quando foi fundido com o estado do Rio de Janeiro. Seu último governador foi Chagas Freitas. Em 1975, com a fusão, Freitas foi substituído pelo Almirante Faria Lima. De acordo com Sarmento (2001) Faria Lima teria sido convocado por Geisel, pelo fato de não ter tradição como político, visto que o novo estado já surgia com uma grande polarização política encampada, de um lado, por Chagas Freitas e, de outro, pelo senador Amaral Peixoto.

\footnotetext{
${ }^{30}$ Apesar de Chagas Freitas ser integrante do PMDB, durante seu mandato como governador, não havia uma oposição em relação ao governo federal. Chagas não era integrante do grupo conhecido como autênticos dentro do PMDB. Esse grupo fazia parte de um grupo dentro da sigla que se portava como um campo de oposição. (DINIZ, 1982)
} 
De acordo com a composição política formada nos espaços carioca e fluminense, Brizola teria que competir com duas forças oposicionistas com territórios eleitorais já bem demarcados. A afirmação de Lima, Fraga e Silva (2014), de que "a base territorial sinaliza uma área paroquial de relações de poder, apropriada pelos agentes políticos e diferentes interesses e bases de reivindicações". (p.131), nos ajuda a compreender a importância da constituição de capilaridades territoriais bem difundidas e consistentes, alicerçadas em relações de comunidade. Isso representava um grande desafio para Brizola, bastante desterritorializado após 15 anos de afastamento da vida política nacional.

De acordo com Lima (2012), o processo de construção territorial é um exemplo de constituição de territorialidades, que são caracterizadas por demandas e aspirações políticas dentro de uma circunscrição eleitoral. Essa situação definia com clareza uma 'geografia do voto' que demarcava territórios bem claros no jogo político-eleitoral. Tal situação criava grandes entraves para que outros candidatos, sem essa base territorial, enfrentassem um quadro eleitoral favorável, pois não estavam acoplados às duas forças igualmente institucionalizadas no poder.

Portanto, os espaços políticos, carioca e fluminense já apresentavam dinâmicas político eleitorais bem consolidadas com duas representações definidas, formando importantes máquinas políticas atuantes sistematicamente, como bem evidencia Diniz (1982), através da forma como as mesmas objetivavam os eleitores, não como atores do processo político, mas como clientes que deveriam ser satisfeitos de acordo com reivindicações personalistas, fundando bases clientelistas que procuravam solidificar seus redutos.

A representatividade desses atores políticos hegemônicos foi marcada pela prática do clientelismo ${ }^{31}$, uma das chaves para entendermos as forças do chaguismo e do amaralismo no estado e na cidade do Rio de Janeiro. Afirma-se, portanto, que esse feitio de fazer política fez dela uma máquina de atuação partidária que enfraquecia as formas de representação democrática. Segundo Castro (2013) “a democracia é uma forma de governo que envolve a sociedade e o território. O que

\footnotetext{
${ }^{31}$ Diniz (1982, p. 19), afirma que o clientelismo é uma peça integrante das engrenagens de um sistema global de exploração e dominação. Sem dúvida, trata-se de um instrumento de incorporação das massas ao quais grupos e classes dominantes tendem a recorrer em certas circunstâncias (...). Assim sendo, recorre-se ao clientelismo para operar a conciliação dos contrários de modo a fazer com que interesses não absorvíveis por uma dada estrutura de poder sintam-se apaziguados, ao invés de incompatibilizados.
} 
a torna um modelo institucional de evidente dimensão geográfica, afetada por questões como: extensão, distância, acessibilidade, escala, população, densidade, infraestrutura, urbanização, estrutura social etc" (p. 24).

A análise da democracia enquanto modelo institucional também pressupõe as questões que afetam os territórios, por isso a importância das variáveis estabelecidas pela geografia, permitindo reflexões sobre a formação dos sistemas de representações partidárias e a formação de bases eleitorais, pois todo processo de disputas relativas ao campo político será pactuada no território, através de mediações, interesses e situações de conflitos observados no mesmo. De acordo com o papel da geografia eleitoral e sua relação com a representação, Castro (2007) afirma que a análise dos sistemas eleitorais, moldados pela percepção de democracia e de representação, deve considerar o papel desempenhado pela organização do espaço e seus constrangimentos, ou rugosidades. Aqui, além dos tradicionais princípios da geografia, localização, extensão, contiguidade acrescidos de forma e função, devem ser incorporados outros, como conflitos e interesses territorialmente ancorados. (p.148)

Diante do exposto, podemos utilizar o questionamento feito por Castro (2015) sobre a presença do fenômeno político na agenda da Geografia. Para a geografia política, a resposta deve ser focada nos marcos que estabelecem regras e limites para disputas de interesses que surgem nas sociedades, o Estado e o governo.

Todavia, para além do quadro institucional de regras e limites apresentados por Castro (2015) consideramos que a dimensão espacial da política enquanto prática - é também marcada como fenômeno, através de clientelismos e da patronagem.

A afirmação acima se relaciona à dinâmica dos partidos políticos, que são formas institucionalizadas, cujos matizes ideológicos vão representar determinados segmentos e interesses de fatias da população. E em um contexto de atuação clientelista, tais partidos têm a sua importância reduzida, já que as máquinas políticas institucionalizadas nos níveis do Estado distorcem as práticas partidárias. Nesse caso o partido enquanto instituição representativa se torna claudicante, pois perde a capacidade de ser instrumento de participação política e passa servir aos interesses de grupos particulares que relegam aos mesmos o voto utilitário para 
garantir benefícios específicos a determinados segmentos eleitorais. Como exemplo dessa prática temos os vereadores "bicas d'água" 32 , tipo de política que caracterizava o chaguismo enquanto governo no estado do Rio de Janeiro.

Como a afirma Diniz (1982):

A máquina se especializa no tratamento tópico dos conflitos sociais, nas medidas parceladas e individualizadas, nas práticas distributivas passíveis de alto grau de desagregação em unidades discretas e isoladas. O processo de aniquilamento da instituição partidária ${ }^{33}$ é levado a um tal extremo que chegamos ao absurdo de um sistema bipartidário em que o partido de oposição não faz oposição. (p.20)

Posto isto, as bases territorializadas na política carioca e fluminense utilizaram as máquinas para aumentar seus redutos eleitorais como estratégia de fortalecimento do seu espaço político. Determinadas ações políticas serão institucionalizadas, ao largo, mas não em separado das instituições formais, pois vão se servir delas para aumentar sua clientela eleitoral. Isso ficou bem claro na forma de fazer política no Rio de Janeiro durante o governo de Chagas Freitas. (DINIZ, 1982)

Dentro desse contexto, foram realizadas as eleições de 1982, quando o candidato 'não institucionalizado na máquina pública' (Leonel Brizola) ${ }^{34}$ enfrentou duas forças políticas estabelecidas no cenário carioca e fluminense.

\footnotetext{
${ }^{32} \mathrm{Um}$ dos vereadores que ganhou essa alcunha foi Miécimo da Silva, político influente da zona oeste do Rio de Janeiro e aliado de Chagas Freitas, uma de suas principais iniciativas desse parlamentar era colocar bicas d'água em bairros que sofriam com o abastecimento em bairros da região definidos por ele como o "Triângulo Carioca" - Guaratiba, Campo Grande e Santa Cruz.(LOPES, 2007)

${ }^{33}$ Nesse contexto, temos outra significação para os partidos políticos dentro de uma estrutura patronal e clientelista. O que ocorre é que dentro dos limites da democracia representativa, muitas vezes os partidos tornam-se instituições particularistas na sua forma de agir, pois não vai contemplar uma coletividade, mas grupos de interesses específicos e, mais que isso, vão buscar atender as especificidades de um determinado segmento ou de segmentos eleitorais.

${ }^{34}$ Analisando os cinco candidatos que disputaram as eleições de 1982, somente dois estavam em legendas que foram fundadas como oposição ao governo vigente no Brasil durante o período de abertura política, Leonel Brizola e Lisâneas Maciel, do Partido dos Trabalhadores (PT). Os três restantes eram Miro Teixeira, do PMDB, principal afilhado político de Chagas Freitas e um dos artífices da política clientelista empreendida pelo mesmo. Além disso, a ala chaguista do partido nunca foi uma oposição ao governo de Brasília. Moreira Franco, do PDS, fazia parte do partido governista, sucessor da ARENA e contava com o apoio de Amaral Peixoto, que tinha muitas bases políticas no interior do estado e, por último, Sandra Cavalcanti, do PTB, que era uma candidata oriunda da antiga UDN. (SENTO-SÉ, 1999)
} 
Segundo Sento-Sé (1999):

A disputa para o cargo de governador do estado iniciava-se envolta em grande expectativa. Além de ser o primeiro pleito para o cargo executivo estadual, em 17 anos, o que lhe conferia um enorme peso no contexto da abertura, estariam à frente forças políticas fortíssimas e suas respectivas máquinas eleitorais. (p.219)

Observando o desenho eleitoral, o General Golbery já vislumbrava a fragmentação das oposições no Rio de Janeiro, pois a falta de integração entre elas ${ }^{35}$ acirrava a disputa, mesmo que temporariamente. Essa desunião entre os grupos oposicionistas que não faziam parte da base de apoio político do governo federal acabou favorecendo, novamente, os dois partidos institucionalizados na máquina estatal $^{36}$, PMDB e PDS. Os demais partidos, ainda muito pequenos, não dispunham de recursos e nem de base logística eleitoral e de campanha eficiente como os dois primeiros.

Todavia, a eleição de 1982 inaugurou um 'novo' marco político para o Rio de Janeiro, pois representou, pelo menos em parte, a mudança em relação à forma como estava estruturado o quadro eleitoral da unidade federada, principalmente em sua escala de âmbito municipal. A disputa eleitoral ficou entre o trabalhista Brizola, o candidato chaguista Miro Teixeira, e o amaralista Moreira Franco. E, contra todos os prognósticos, venceu Leonel Brizola.

A eleição de Brizola distinguiu o Rio de Janeiro do restante do país, pois o candidato 'não institucionalizado' foi o único governador fora do eixo dominado pelo PMDB e pelo PDS, e isso, por si só, já era uma novidade e um grande golpe no regime militar bem como nas lideranças estaduais cujos apadrinhados,

\footnotetext{
${ }^{35}$ Esse acirramento vai ser evidenciado, principalmente após as eleições, pois vão ser necessárias intensas negociações com a ala peemedebista na Assembleia Legislativa para que a governabilidade do estado fosse possível; caso contrário, a relação com o legislativo traria muitas dificuldades para o governo de Brizola.

${ }^{36}$ É interessante mostrar que apesar de o PMDB ser, em teoria, um partido de oposição, no caso do Rio de Janeiro a política de Chagas Freitas nunca foi realmente oposicionista em relação ao governo federal. É possível afirmar que sua política foi mais centrada nas escalas municipal e estadual. Diniz (1982, p. 18) afirma que: "Não menos impressionante é o fato de que todos, favorecedores e favorecidos, se assemelham ao dono da máquina. O poderoso chefão dá o tom. Sendo ele próprio cliente do governo federal, sua conduta se pauta pela regra da omissão. O líder do grupo inauguraria um estilo que se tornou o modelo seguido pela representação chaguista no Congresso - a não participação no debate das grandes questões nacionais, a supressão do conflito pela via da renúncia à existência autônoma da vida pública."
} 
considerados os favoritos, foram derrotados. Além disso, a eleição de Leonel Brizola confirmou, mais uma vez, a tradição oposicionista do Rio de Janeiro.

A vitória de Brizola e do Partido Democrático Trabalhista no Rio de Janeiro, em 1982, principalmente na metrópole carioca e em sua região metropolitana, deu início à hegemonia brizolista nos espaços carioca e fluminense. Isso configurava uma mudança de paradigma político, pois territorializou e enraizou o brizolismo e sua forma de governo ${ }^{37}$ nos espaços mencionados.

Nas eleições de 1982, houve uma redefinição da geografia eleitoral do Rio de Janeiro. A menor votação recebida por Brizola deu-se no interior do estado, onde as duas legendas partidárias oriundas do bipartidarismo tinham mais capilaridade. Na cidade do Rio de Janeiro e sua Região Metropolitana, a vitória de Brizola deveuse, em parte, à fragmentação dos votos entre os candidatos Miro Teixeira (PMDB) e Moreira Franco (PDS). A seguir apresento os mapas eleitorais que mostram o desempenho dos três principais candidatos na disputa pelo governo do estado do Rio de Janeiro nas eleições de 1982. Os mapas evidenciam a distribuição dos votos válidos para o pleito eleitoral mencionado.

\footnotetext{
${ }^{37} \mathrm{~A}$ força do brizolismo pode ser percebida pelas através dos candidatos eleitos pelo partido, mesmo com alguns reveses, como foi o caso da derrota nas eleições para o governo do estado do Rio de Janeiro, quando Darcy Ribeiro (PDT) perde para Moreira Franco (PMDB). Brizola foi eleito novamente em 1990 e no final da mesma década, Anthony Garotinho se torna governador pelo PDT. Mesmo alguns candidatos que migraram do PDT para outros partidos, como foi o caso de César Maia e Marcello Alencar, se elegeram respectivamente, prefeito e governador e fizeram parte do quadro pedetista durante toda década de 1980.
} 


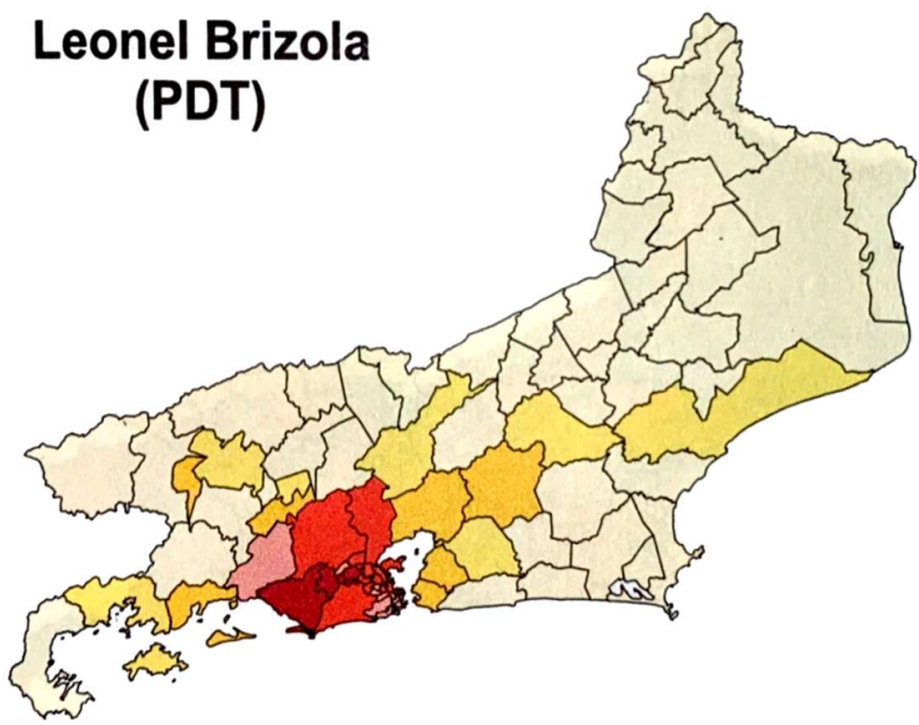

Mapa1: Votos válidos em Brizola. Fonte: Alckmin e Kuschinir, 2001

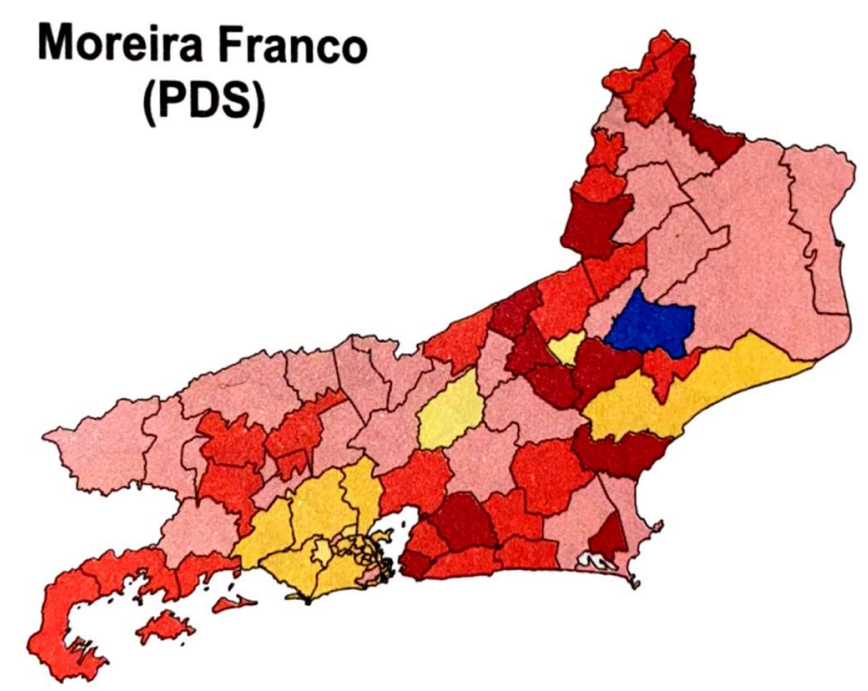

Mapa 2: Votos válidos em Moreira Franco.

Fonte: Alckmin e Kuschinir, 2001 


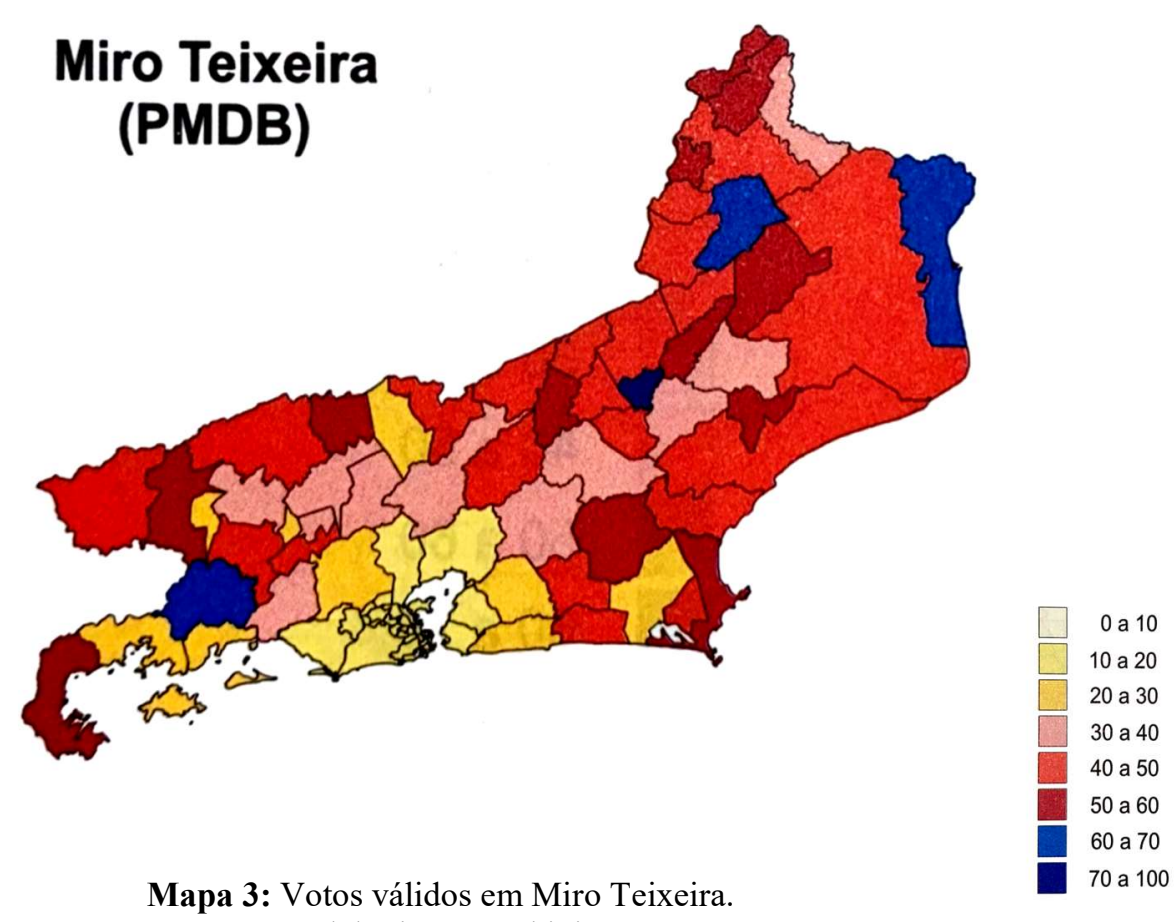

Mapa 3: Votos válidos em Miro Teixeira. Fonte: Alckmin e Kuschinir, 2001

\begin{abstract}
Alckmim e Kuschnir (2001), em artigo intitulado 'Mapas Eleitorais Fluminenses', concluem que:

Os mapas revelam que essa também foi uma divisão entre as tradições políticas do interior e da capital. Brizola alcança entre 45 e $60 \%$ dos seus votos no Rio e na área metropolitana, enquanto Moreira atinge essa mesma faixa justamente nos municípios do interior do estado. No entanto, sendo esse também o perfil de Miro, há uma divisão na força eleitoral do interior, o que contribui para a vitória do candidato do PDT. (p.106)
\end{abstract}

Partindo de uma perspectiva geográfica, Brizola conseguiu grande parte de seus votos em regiões periféricas da cidade do Rio de Janeiro, como a zona Oeste e também na sua Periferia imediata, a Baixada Fluminense, redutos estabelecidos da política chaguista. Sobre essa conquista eleitoral, Santos (2015) explica que tal apoio ‘inesperado' veio de lideranças comunitárias que reforçaram a sua ação nas regiões 'menos infraestruturadas' da metrópole carioca, a partir da remoção de favelas e do ambiente de carestia no qual a cidade afundava no início dos anos 1980. Dentre essas lideranças, destacam-se às ligadas à Federação de Favelas do Estado do Rio de Janeiro (FAFERJ) e à Federação das Associações de Moradores do Estado do Rio de Janeiro (FAMERJ), já que o isolamento das famílias removidas abria espaços para 'novas representações locais' de agentes comunitários populares 
ligados aos 'discursos socializantes' que cresciam nos âmbitos das associações de bairro das vilas operárias em consolidação na zona Oeste, por exemplo. Com isso, emergiram novas conexões entre padrões espaciais de 'isolamento demográfico' o discurso do descaso público com a mobilidade urbana, geração de emprego e baixa infraestrutura dos bairros populares criados com as remoções - que ampliava o apoio político da massa urbana a políticos 'libertadores'.

Assim sendo, Brizola obteve sua votação mais expressiva em regiões pauperizadas, com graves problemas estruturais, carência de infraestrutura, de saneamento básico, de mobilidade urbana, entre outros e que no seu campo discursivo também pregava o fim do processo de remoção de favelas, uma política pública de habitação da qual os partidos que dominavam a máquina pública comungavam.

Ainda segundo Santos (2015), além dos atributos territoriais dos moradores votantes na cidade, e sua Periferia imediata e próxima, devem ser somados aos eleitores do PDT (e, portanto, de Brizola) os níveis de desigualdade espacial vivenciado por eles no esgarçamento do tecido socioespacial (SOUZA, 1989), a crescente má distribuição de renda e o baixo grau de escolaridade dos eleitores do candidato eleito. Sendo assim, enfatiza-se que o apoio eleitoral em Brizola nas regiões dominadas por esses perfis socioespaciais uniu os temas sobre 'reformas urbanas inclusivas', com o discurso humanizador de valorização das pessoas assoladas pela violência institucional presente na ação das forças policiais, a educação popular através de um programa especial de educação ${ }^{38}$ e a 'democratização' da mobilidade no espectro espacial metropolitano, gerando uma convergência entre o campo discursivo do partido e os anseios de parcela expressiva da população desses espaços à margem dos direitos fundamentais. Tal conexão transferiu os tradicionais votos dados ao chaguismo para o brizolismo.

Brizola no seu discurso político procurava se distanciar dos objetivos traçados pela gestão pública que dominava as representações do novo estado do Rio de Janeiro, desde o final da década de 1960 até 1975: o da modernização gerada pelas obras gigantescas, do embelezamento da cidade e da remoção da habitação

\footnotetext{
${ }^{38}$ Foco importante do campo discursivo do brizolismo foi o da 'educação', como afirma Sento-Sé (1999). Para ele, a bildung brizolista teve como uma de suas principais características a difusão da cultura através da universalização do ensino como forma de "salvar" a sociedade. (p.125).
} 
do morador pobre. Seu discurso político era voltado para a escala local, mostrandose como os problemas vivenciados cotidianamente tinham origem nos 'problemas nacionais' gerados pela dependência da rede do subdesenvolvimento e das 'perdas internacionais'. Tal discurso aproximou dele também outra parcela de eleitores oriundos de grupos sociais heterogêneos, como profissionais liberais, trabalhadores das classes média e baixa, muitas vezes, sem carteira assinada e funcionários públicos. (SANTOS, 2015).

De acordo com Costa (1992), a questão da representatividade política é complexa e não se restringe ao número de representantes, mas sim ao problema da própria representatividade, que é formada pelo sistema político. Nesse sentido, a representatividade que Brizola e o brizolismo ganharam no Rio de Janeiro, principalmente na metrópole carioca e em sua região metropolitana após as eleições de 1982, está relacionada às 'territorialidades de necessidades' de determinados segmentos sociais, considerados marginalizados e que encontraram no discurso do pedetista uma possibilidade de conexão com as situações e problemas estabelecidos em suas circunscrições eleitorais ${ }^{39}$. Portanto, para além do sistema político na formação da representatividade política, as temáticas eleitorais 'dos solicitantes' foram de grande importância para o êxito da campanha de Brizola e, também, na disputa não somente da representação eleitoral, mas também da espacial, o que definiu uma nova geografia dos votos na cidade e em outras regiões do conglomerado metropolitano.

Através de uma análise espacial é possível observar na questão política partidária a formação das bases políticas, bem como as estratégias dentro do sistema e da temática eleitoral, a apropriação do espaço por um determinado grupo político, partindo-se de um viés programático e discursivo que encontre eco em diferentes atores que vão convergir de acordo com o que é apresentado na campanha. (TERRON, 2012)

As bases eleitorais, de um determinado candidato ou partido, estão relacionados à quantidade de apoiadores que estes conseguem angariar, com a finalidade de transformar uma determinada circunscrição eleitoral em um reduto

\footnotetext{
${ }^{39} \mathrm{~A}$ circunscrição eleitoral deve ser entendida como o espaço geográfico onde se disputa determinada eleição. Essa definição faz parte do Glossário Eleitoral Brasileiro do Tribunal Superior Eleitoral (TSE).
} 
político, cuja formação parte de uma vinculação entre diferentes atores do processo político, que constituem os quadros partidários ou não. Há, muitas vezes, relações informais, através de laços de vizinhança, por exemplo. Por outro lado, também há o campo de ação dos partidos políticos que procuram se identificar com o eleitorado local, através de pautas sensíveis às particularidades locais não somente reivindicatórias, mas também pelo número de eleitores que habitam esse espaço, o que o torna muito cobiçado pelas legendas. Além disso, através da campanha, os partidos, como o PDT à época, procuraram cooptar atores como movimentos associativistas, para aumentar o seu capital eleitoral em um determinado espaço, como ocorrido na zona Oeste e nos subúrbios do Rio de Janeiro, espaços de intensa disputa política ${ }^{40}$, como podemos observar durante períodos distintos da historiografia eleitoral da "Cidade Maravilhosa".

A formação das bases é dada, sobretudo pelas demandas específicas que são observadas nos territórios em disputa no jogo político, em que os partidos e, muitas vezes o próprio interesse particular de um político, busca influenciar e mobilizar grupos de interesses locais. Madalegno (2013) sobre essa temática afirma que há diferentes tipos de demandas territoriais diretas passíveis de serem mobilizadas pelos grupos de interesses na busca por influência na agenda política. As necessidades e anseios de grupos de interesses (com atuação interna ou externa do partido) diretamente ligados a territórios políticos específicos do representante refletem, em grande medida, as condições sociais, econômicas e demográficas desse território. (p.79)

É possível afirmar que a política partidária, através da intenção de atender a demandas territoriais, cria através do discurso político e das agendas estabelecidas, tanto pelo partido, como pelo candidato, independente de questões ideológicas, a legitimidade de sua representação no território, por isso a busca por alianças locais para compreender as características e condições vigentes no espaço que se quer representar. Castro (2007) afirma sobre a representação política, "que não é possível

\footnotetext{
${ }^{40} \mathrm{~A}$ zona Oeste foi reduto eleitoral de vários candidatos de natureza 'carismática' e 'messiânica'. Depois do brizolismo, o garotismo (Anthony Garotinho) tomou lugar. Mais recentemente, no século XXI, ascendeu a essa posição o pastor evangélico e ex-prefeito Marcelo Crivella, em uma rede de conexão do neopentecostalismo com as milícias (substitutas do narcotráfico), que tornam, muitas vezes, interpretações pessoais de ordem e segurança como lei para a coletividade. Para aprofundar o tema, recomenda-se as leituras de Braga (2013), Misse (2011) e Juwer (2011).
} 
compreendê-la sem analisar as condições existentes nos espaços da vida, de interesses, de produção e de circulação das sociedades. É justamente essa dimensão espacial do sistema de representação política que interessa a geografia política, em geral, e a geografia eleitoral em particular”. (p.148)

Sobre as bases e os territórios eleitorais foi possível elaborar o esquema três, para ilustrar as relações entre os dois componentes espaciais que têm interferência direta nas campanhas eleitorais e no resultado das mesmas.

Esquema 4: Análise espacial das bases eleitorais

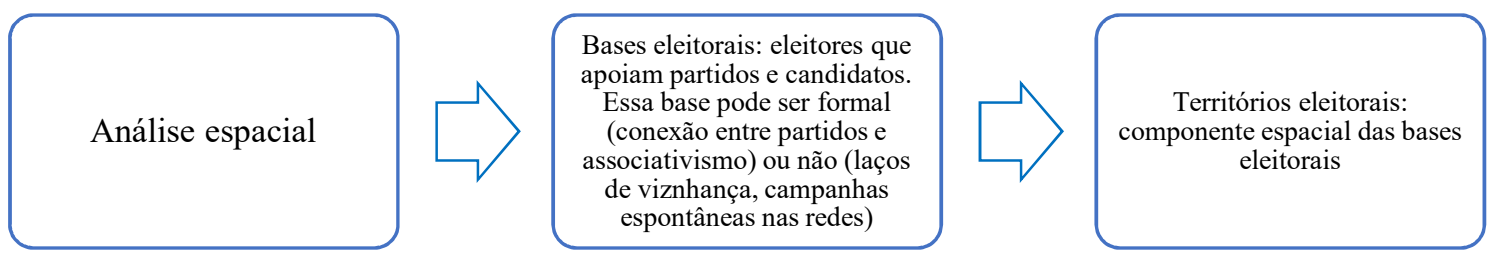

Fonte: Elaborado pelo autor (2021), a partir de Terron (2009).

Brizola e seu discurso de base popular e nacionalista, de caráter oposicionista ao regime vigente, se tornaram uma possibilidade a partir de situações diversas que poderiam ser ilustradas por diferentes variáveis, no âmbito nacional, pela saturação do regime à época, pelo discurso voltado para segurança pública e educação 'de qualidade' e por propostas que iam ao encontro dos anseios de camadas populares, como aquelas que retiravam das políticas públicas as migalhas do esquecimento e falta de prioridade.

Quanto à condição de atingir a população em suas diversas faixas, independentemente de como isto possa ser interpretado, me reporto a Sento-Sé (1999). Para ele, a composição do PDT como um partido político novo que não apresentava quadros competitivos eleitoralmente precisa ter um novo apelo. Assim sendo,

O PDT lança candidatos que nada tem a ver com a política profissional. Dentre esses candidatos temos o cacique Juruna e o cantor popular Agnaldo Timóteo. Enfatizava que a atividade política deveria ser popular, acessível a todos que dela quisessem fazer parte e não apenas a políticos profissionais. (...) Estas personalidades representavam o povo em geral, mas também os grupos minoritários, de cuja defesa o PDT, desde sua fundação pretendia ser seu principal vocalizador. Eram lançados, então 
candidatos negros, mulheres, artistas e, com um glamour especial, a mais conhecida liderança dos povos indígenas daquela época. (p. 224)

A chegada de Brizola e do brizolismo no governo do estado impunha desafios importantes, pois sua estrutura funcional e ideológica desejava instituir uma nova política nos espaços carioca e fluminense, mas para isso seria necessária outra configuração institucional, o que não significa uma ruptura com o que existia antes. A eleição de Brizola, em 1982, territorializou e institucionalizou o brizolismo no Rio de Janeiro, substituindo, em parte, o chaguismo, mas sem retirá-lo de cena totalmente, pois a sobrevivência e a formulação de políticas públicas, bem como a concretização das mesmas, precisavam de alianças com membros do grupo anterior para que fosse permitida a governabilidade do novo representante do executivo estadual.

Dada às especificidades da política do espaço carioca e fluminense, as instituições não estariam, de acordo com Nunes (2018, p.20) "num campo de análise redutor, ou seja, somente circunscritas às normas, leis, regras e organizações do Estado." No caso do jogo político a ser observado no Rio de Janeiro, buscar a institucionalidade é considerar um campo mais amplo do que se entende por instituição, pois outros condicionantes tiveram que surgir para que o novo governo pudesse ser instituído. Nesse sentido, devemos considerar a concepção de 'instituição alargada' (REIS, 2009), ou seja, quando a institucionalidade não está vinculada somente a leis, normas e regras, mas também às influências dos principais atores políticos e econômicos que compõem a rede de significados de representação em determinada escala e suas convenções.

Tal condição é pertinente com a mudança do quadro político eleitoral no Rio de Janeiro, porque possibilitou a introdução de dinâmicas de ação pública 'mais sociais', a partir das concepções de Brizola e da Carta de Lisboa na governança do estado e na cidade do Rio de Janeiro. No entanto, as mudanças desejadas foram lentas em se tratando de novos arranjos e de políticas públicas que levariam a rupturas de lógicas cristalizadas na gestão carioca e fluminense, trazendo muitas dificuldades ao poder instituído no processo eleitoral. 
Por isso, de acordo com Reis (2009),

O paradigma institucionalista assenta-se, (...), na concepção essencial de que a atividade humana é um ato coletivo e de que os indivíduos superam as suas irredutíveis limitações através das regras e convenções, isto é, de padrões de ação e comportamento que resultam de interações, mais do que capacidades inatas ou lógicas universais. Além disso, o mundo da ação é um mundo de que faz parte o conflito e a distribuição assimétrica de poder. Os indivíduos, por sua vez, estão sujeitos a irracionalidades, imperfeições e contingências capazes de afetar os modos de coordenação das relações. (p.57)

No estado do Rio de Janeiro, tal paradigma após as eleições de 1982, apresentou-se a partir desafios na modificação do quadro institucional que estava vigorando tanto em terras cariocas quanto fluminenses, por conta de uma estrutura de poder territorializada, herança das lideranças políticas derrotadas no pleito eleitoral. $\mathrm{O}$ quadro burocrático enraizado em níveis estatais em crise sob diversos aspectos (o econômico passou a ser o mais relevante após a fusão Guanabara - Rio de Janeiro), emperrava a máquina governamental e o quadro institucional gerava dificuldades e entraves para administração pública, o que necessitou 'concessões' nem sempre republicanas. As forças de resistência às mudanças evitavam rupturas, mas aceitavam 'transições negociadas'.

De acordo com Nunes (2018):

(...) os territórios não são somente o produto de lógicas universais, ou engrenagens passivas de um sistema-mundo que evolui segundo princípios econômicos que lhes são alheios; antes, são também produtos das ações de atores reflexivos e territorialmente situados que cooperam ou entram em conflito para modificar (ou manter) o quadro institucional que, ao mesmo tempo, constrange ou habilita a sua ação. (p.22)

A eleição de Brizola representava um novo arranjo político no estado do Rio de Janeiro. Em meio a uma eleição que apenas elegeu governadores do PMDB e do PDS o trabalhista venceu o pleito no segundo estado mais importante da Federação, rompendo a hegemonia do PMDB em terras fluminenses. Portanto, o grande desafio era criar um quadro político e institucional que possibilitasse sua governabilidade. A nova malha institucional que iria se criar no estado não podia deixar de atender às relações de poder que já estavam enraizadas nos espaços carioca e fluminense e que eram oposição ao novo governo, vigente a partir de 15 de março de 1983. 
Apesar de o PDT ter ficado com a maior bancada estadual, as duas bancadas dos principais partidos oposicionistas davam maioria a estes últimos, fazendo com que o governo que se iniciava tivesse que negociar para manter a sua governança política. Porém, isso não foi sem embaraços para o governo brizolista ${ }^{41}$, que teve que estabelecer alianças com setores do PMDB para não ter minoria no legislativo.

Em outros termos, um novo quadro político-institucional mais afinado com os pressupostos brizolistas não poderia ser realizado através de uma ruptura, mas sim por bases políticas negociadas, em acordo com aquilo que ficou claramente indicado no mapa eleitoral, que no interior as máquinas políticas tradicionais continuam a definir as estratégias de gestão do espaço fluminense.

A governabilidade de Brizola dependeu de estratégias de alianças políticas com o PMDB chaguista por algumas questões. A primeira era adquirir maior representatividade na Assembleia Legislativa do Estado do Rio de Janeiro. A segunda aproveitar o conhecimento que a burocracia, já instalada tinha da máquina pública para facilitar a administração pedetista e, por último, o estabelecimento de alianças políticas que poderiam aumentar a capilaridade e a territorialização do brizolismo em espaços interioranos dominados por máquinas políticas já consolidadas.

Sobre o resultado eleitoral de 1982, Sento-Sé (1999), compreende que representou para Brizola seu retorno ao centro do poder, devido ao destaque por ter sido o único a quebrar a hegemonia nacional PMDB/PDS e a romper com a hegemonia do antigo MDB no Rio de Janeiro. O autor acrescenta que:

Segundo essa perspectiva dos brizolistas, sua vitória era encarada, naquele momento, como a vitória do moderno, representado pelo socialismo moreno ${ }^{42}$, alinhado à Internacional Socialista e a social democracia europeia ${ }^{43}$, contra o atraso

\footnotetext{
${ }^{41}$ Um episódio retratado no livro 'Brizolândia: um grito na praça' (1993) mostra o descontentamento de brizolistas e apoiadores com Brizola com a não maioria parlamentar. Para enfrentar a questão do apoio na Assembleia Legislativa, Brizola propôs uma coalizão com o PMDB, inclusive com a ala chaguista, pois havia somente duas opções, governar com eles ou não governar.

${ }^{42}$ Darcy Ribeiro fala sobre um socialismo que quer 'passar o Brasil a limpo', um Brasil que seja de todos e dele seria construída a nossa civilização. Teríamos assim, um socialismo próprio e que surgiria da nossa história. Esse socialismo seria mestiço como o povo brasileiro; portanto, nossa experiência seria única, no sentido de buscar um caminho que não fosse por influência das tendências socialistas de outros países.

${ }^{43}$ Quanto a influência da social democracia europeia, ela se faz presente no documento fundador do Partido Democrático Trabalhista (PDT), a Carta de Lisboa. Alguns temas importantes passam a
} 
representado pelo chaguismo, pelo PDS e pelos comunistas do PCB ligados ao MDB. (p.230)

A partir da eleição para o governo do Rio de Janeiro, Brizola começava a sua trajetória em direção a uma plataforma mais ampla: a de ser o presidente do país. Com a capitalidade do Rio de Janeiro, a política local iniciou o seu percurso para a tentativa da gestão na escala nacional. Tal estratégia já podia ser identificada nos chamados 'compromissos prioritários', lançados na Carta de Lisboa, que eram divididos em partes: os planos políticos, econômico, social, de educação e cultura e internacional; portanto, desde o seu retorno para o Brasil, Brizola tinha como meta o governo federal.

No quadro quatro, temos alguns compromissos da Carta de Lisboa, que comprovam o objetivo de Brizola com seu retorno ao Brasil e seu projeto político.

Quadro 4: Compromissos prioritários da Carta de Lisboa

\begin{tabular}{|ll|}
\hline \multicolumn{1}{c|}{ Compromissos Prioritários } \\
\hline $\mathbf{1}^{\mathbf{0}}$ & $\begin{array}{l}\text { Com as crianças e jovens. Salvar as crianças e adolescentes é uma causa de } \\
\text { salvação nacional. }\end{array}$ \\
\hline $\mathbf{2}^{\mathbf{0}}$ & $\begin{array}{l}\text { Interesse dos trabalhadores, especialmente as grandes maiorias populares } \\
\text { que vivem em situação de pobreza. }\end{array}$ \\
\hline $\mathbf{3}^{\mathbf{0}}$ & $\begin{array}{l}\text { Com a mulher e contra a sua discriminação propugnando por sua efetiva } \\
\text { participação em todas as áreas de decisão. }\end{array}$ \\
\hline $\mathbf{4}^{\mathbf{0}}$ & $\begin{array}{l}\text { Com a causa das populações negras como parte fundamental da luta pela } \\
\text { democracia, pela justiça social e a verdadeira unidade nacional. }\end{array}$ \\
\hline $\mathbf{5}^{\mathbf{0}}$ & $\begin{array}{l}\text { Com a defesa das populações indígenas, contra o processo de extermínio } \\
\text { físico, social e cultural. }\end{array}$ \\
\hline $\mathbf{6}^{\mathbf{0}}$ & $\begin{array}{l}\text { Com a defesa da natureza brasileira, contra a poluição e deterioração do meio } \\
\text { ambiente. }\end{array}$ \\
\hline $\mathbf{7}^{\mathbf{0}}$ & $\begin{array}{l}\text { Com a recuperação para o povo brasileiro de todas as concessões feitas a } \\
\text { grupos estrangeiros, lesivas a nosso patrimônio. }\end{array}$ \\
\hline
\end{tabular}

Fonte: Elaborado pelo autor (2021), a partir do Estatuto do Partido Democrático Brasileiro, 2006.

serem norteadores da do trabalhismo brizolista, ou seja, do Novo Trabalhismo, como é o caso da discussão em torno das minorias (negros, mulheres, índios). Essas discussões vão fazer parte das políticas públicas adotadas pelo governo de Leonel Brizola, como veremos no próximo capítulo.

${ }^{44}$ Observando o quadro referente aos compromissos prioritários, percebe-se que todo o programa brizolista e pedetista, tinha uma aspiração nacional. Fica claro no primeiro uma das principais bandeiras de Brizola, a educação, que já havia sido seu principal programa quando governador do Rio Grande do Sul, com a criação das Brizoletas, num projeto que construiu milhares de escolas no estado sulino. Também observamos a influência da social democracia europeia nos suas políticas inclusivas e de reconhecimento das minorias. O nacionalismo também vai estar presente, na colocação sobre o meio ambiente e, também no $7^{\circ}$ compromisso, que no futuro o governador do estado vai se referir nos seus discursos com as chamadas "perdas internacionais". 
Fica exposta no quadro, a tônica das políticas brizolista e pedetista, cujo campo discursivo assume diferentes escalas de atuação não se restringido apenas ao local, mas também a escalas e problemas mais amplos de competência de esfera nacional. Dessa forma, o seu governo se ocupava também de questões de grande repercussão nacional, mas que pela capitalidade remanescente ou ativa, da cidade do Rio de Janeiro poderiam ser repercutidas em escala nacional. Ou seja, o Rio de Janeiro se configurava como 'o território laboratorial' das políticas brizolistas, tornando-as visíveis e divulgadas a partir da vitrine que essa cidade sempre fora nas escalas nacional e internacional. Em 1989, concorreu à eleição nacional, obtendo expressiva votação, garantindo o terceiro lugar no pleito. No entanto, ficou demonstrado que, apesar da projeção que suas políticas puderam ter nacionalmente, a capitalidade do Rio de Janeiro, por si só não foi suficiente para elegê-lo como presidente da Federação.

Nas imagens cinco e seis temos a vitória de Brizola nas eleições de 1982 e sua posse como governador do Rio de Janeiro.

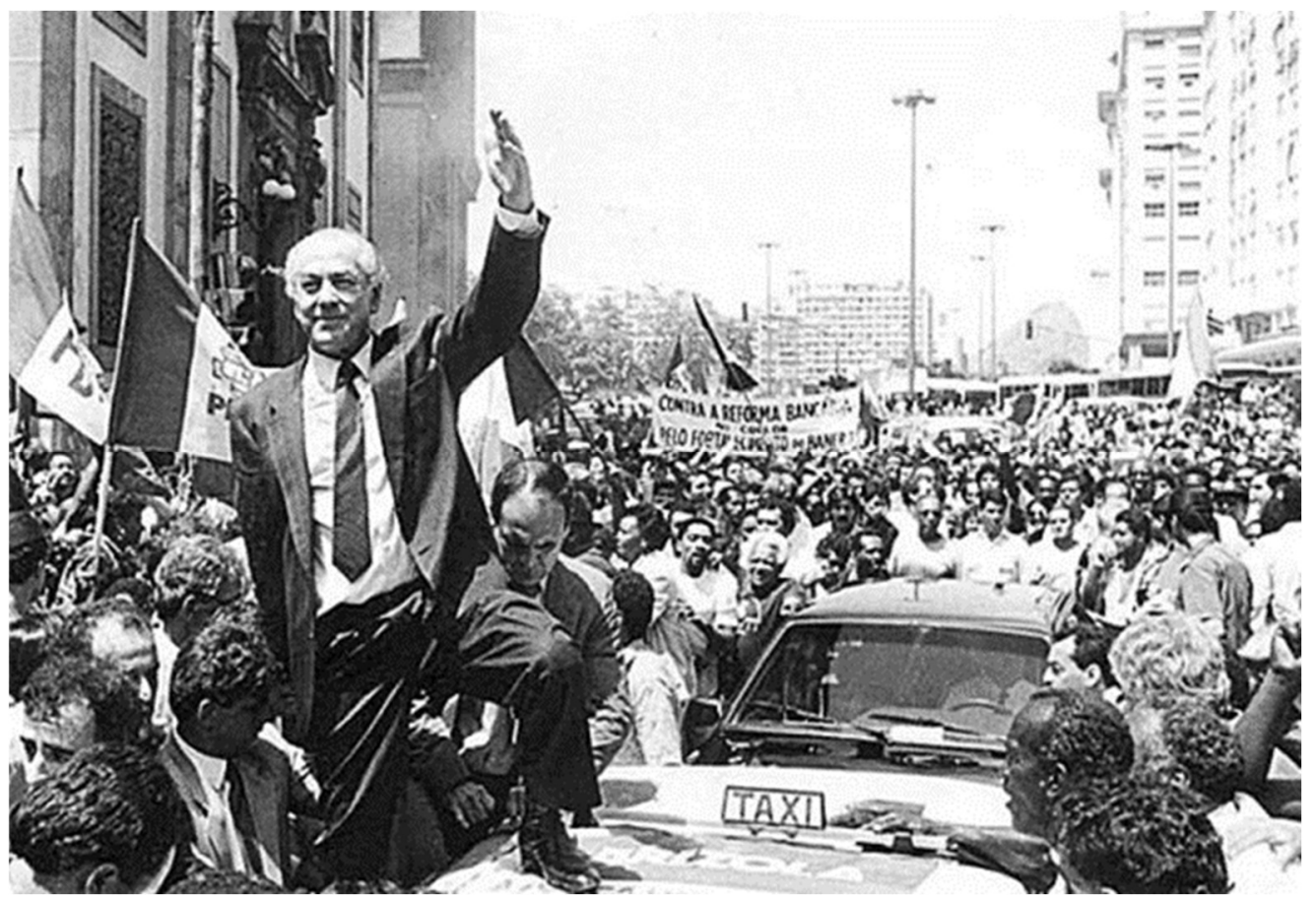

Imagem 5: Brizola sendo conduzido por taxistas após tomar conhecimento do resultado das eleições.

Fonte: pdt.gov.br 


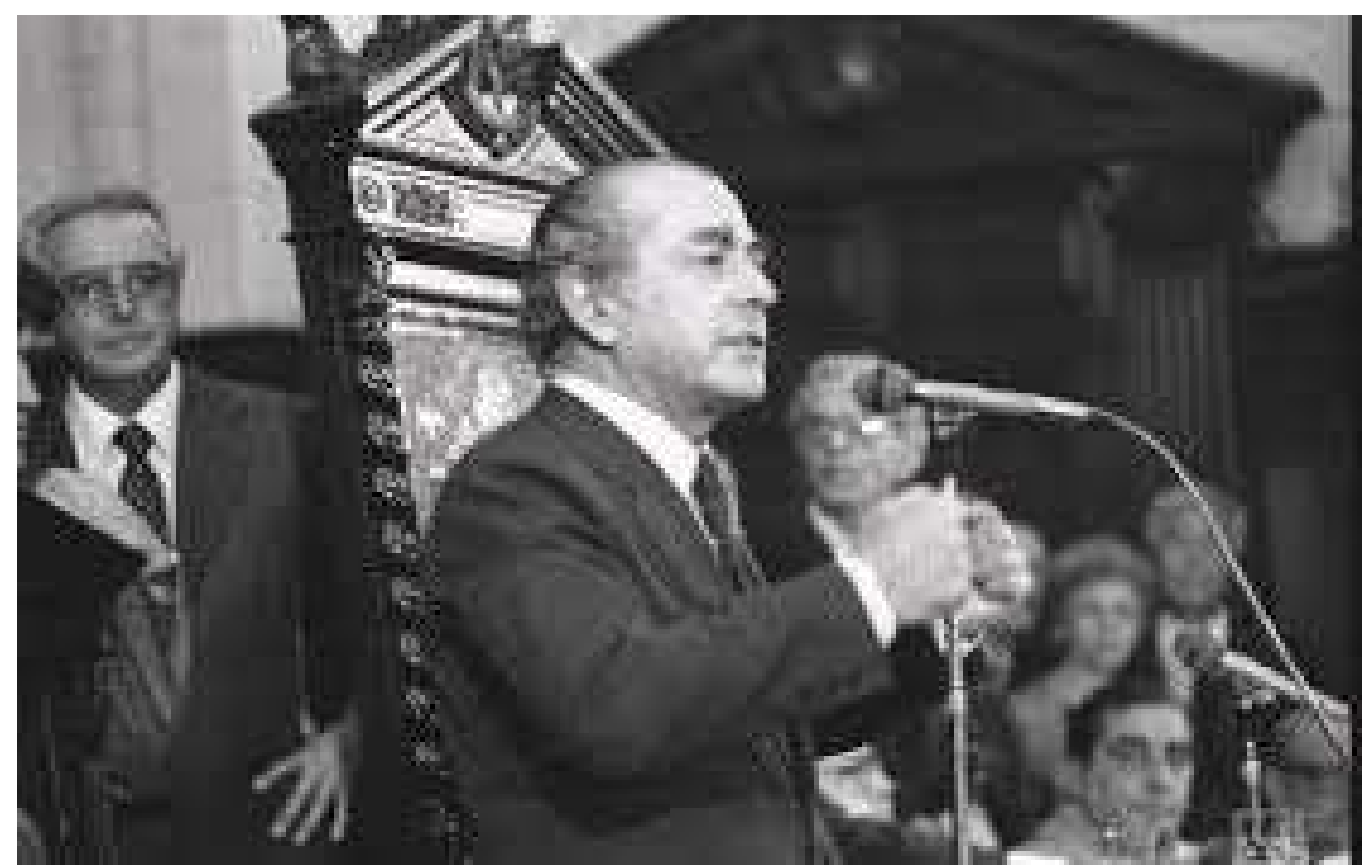

Imagem 6: Brizola tomando posse na Assembleia Legislativa do Rio de Janeiro. Fonte: Jornal do Brasil.

\subsection{Rio de Janeiro: a importância da capitalidade para institucionalização do Brizolismo}

Cabe nesse momento, discutir a capitalidade do Rio de Janeiro. A cidade, mesmo tendo perdido a condição de capital brasileira em 1960, o que mudou o marco institucional do espaço carioca, ainda emana visões e interpretações sobre ela como 'a cidade vitrine', 'maravilhosa', o epicentro da política brasileira, ambiente de importantes manifestações políticas e culturais na história do país.

A discussão sobre a capitalidade do Rio de Janeiro terá, nesta tese, os alicerces teóricos de autores como Azevedo (2016), Motta (2001) e Osório (2011). No entanto, procuraremos conceber uma visão própria sobre a capitalidade da cidade, a partir do fenômeno político do brizolismo no seu território, já que foi a partir dele que Brizola procurou firmar suas bases políticas para ganhar visibilidade nacional.

A cidade do Rio de Janeiro sempre apresentou grande centralidade ao longo da sua histórica político-administrativa, econômica, militar e cultural na escala nacional. Obras como as de Osório (2011), Motta (2001), Osório e Versiani (2019) e Enders (2015) devem ser lidas para a compreensão do tema com maior propriedade. 
No ano de 1960, todavia, houve a transferência da capital do país para a cidade de Brasília, no Planalto Central, e a metrópole carioca perdeu, com isso, sua condição pretérita.

A perda da capital, sem dúvida, foi um grande golpe para cidade do Rio de Janeiro, o que gerou um esvaziamento de alguns símbolos que garantiam a capitalidade para o espaço carioca, mas nem por isso perdeu sua "memória de capitalidade" (MOTTA, 2000).

A cidade do Rio de Janeiro teve como um de seus pontos de ascensão ser um espaço de articulação do território nacional, sendo possível afirmar que institucionalmente esse foi um dos pontos que proporcionou a capitalidade para o espaço carioca.

A perda da condição de capital, sem dúvida, marcou uma ruptura institucional; no entanto, autores como North (1993), Hordgson (1997) e Veblen (1934), nos permitem dizer que o Rio de Janeiro não perdeu sua capitalidade. Ainda nesse contexto, Argan (1964) afirma que todos os países possuem uma cidade que é sua referência internacional e Motta (2001) evidencia que há cidades que são "o lugar da política e da cultura, núcleo da sociabilidade intelectual e produção simbólica, teatro do poder e lugar da memória” (p.24).

Para Azevedo (2016): a capitalidade do Rio de Janeiro antecede seu status de capital da colônia e mesmo com a perda da condição de capital da República, essa capitalidade não foi abalada.

Azevedo (2016) também compreende que a capitalidade do Rio de Janeiro, além do sentido político, estava atrelada à difusão de "um modelo culturalista ou civilizacional". Concordamos que, ao menos, desde o período imperial, a cidade é o berço e difusora de cultura e símbolos identitários para o restante do país. Esse modelo civilizacional não seria construído somente através da noção de progresso, mas também de sua funcionalidade e de sua organicidade ${ }^{45}$.

\footnotetext{
${ }^{45}$ Azevedo (2016) ilustra bem essa ideia quando fala sobre os dois projetos de reforma urbana que foram realizados concomitantemente na cidade do Rio de Janeiro. A reforma comandada por Pereira Passos (1902-1906) tinha como uma de suas principais características fazer com que a cidade apresentasse um viés culturalista aproximando-a da noção de civilização que o Imperador Pedro II vislumbrava. Já a proposta pelo presidente paulista Rodrigues Alves era tornar a cidade um lugar-
} 
A partir das considerações sobre o que se entende por capitalidade para os três pesquisadores que nortearam a base de referência deste capítulo, as questões identitárias vão permear o pensamento sobre o conceito. Em Azevedo (2016), destaca-se o cosmopolitismo do Rio de Janeiro, uma cidade da consagração de movimentos políticos e culturais, cidade referência para o restante do país. Osório (2015) também considera o valor simbólico do cosmopolitismo, evidenciando o papel nacional do Rio de Janeiro, pois os acontecimentos nesse espaço não ficam restritos ao seu território, mas atingem a escala nacional; por isso sua ênfase na dialética local/global. Em Motta (2001), a capitalidade vai ser observada por um viés simbólico, escapando do institucionalismo formal, aquele voltado para leis e normas, além destacar o aspecto identitário permeado por questões culturais e históricas. Nesse sentido, ela enfatiza o cosmopolitismo do Rio de Janeiro, pois se subtende que a metrópole carioca possui uma abrangência nacional.

A partir dessa condição de capitalidade, o Rio de Janeiro foi escolhido como domicílio político de Brizola, pois, segundo ele mesmo, estaria no "tambor político do Brasil". Para o trabalhista, a metrópole carioca ainda era um polo irradiador da política nacional, um espaço capaz de dar visibilidade a seu campo discursivo em uma escala nacional.

Com isso, vamos analisar a questão da centralidade e da capitalidade do Rio de Janeiro, bem como sua importância para Brizola, o brizolismo e, também para o Partido Democrático Trabalhista e sua institucionalização nacional, que teve no estado e na cidade do Rio de Janeiro, seu principal reduto político ${ }^{46}$.

Mesmo com a perda do marco institucional de capital e da centralidade política em relação às grandes discussões nacionais, a memória de capitalidade não foi eliminada do Rio de Janeiro, nem com a migração da administração para o Planalto central, não houve uma quebra da dinâmica institucional de uma forma

\footnotetext{
função, observando nas transformações urbanas, um projeto nacional. Teremos dessa forma duas lógicas presentes no projeto de reforma urbana, uma de espaço-uso e outra de espaço-função.

${ }^{46}$ Desde as eleições de 1982, não somente o pedetismo, mas principalmente o brizolismo dominaram tanto a política carioca como fluminense, isso pode ser constatado através dos inúmeros governadores e prefeitos que foram eleitos pela legenda e, mesmo após algumas cisões, outros candidatos que já não estavam mais no PDT, conseguiram sucesso em seus pleitos eleitorais com apoio de brizolistas. Brizola foi governador por duas vezes, 1983-86 e 1990-94, depois tivemos Anthony Garotinho 1999, que vai deixar o PDT ainda como governador. Prefeitos o PDT elegeu Marcelo Alencar e Saturnino Braga. Fora isso dois ex-pedetistas conseguiram o executivo estadual e municipal, Marcelo Alencar e César Maia.
} 
abrupta. Para corroborar essa observação, utilizamos a afirmação de Versiani (2019):

É nessa perspectiva que se pode aferir que a cultura de capitalidade do Rio de Janeiro acaba por contribuir para que nessa região demorasse a ocorrer à percepção da quebra da dinâmica institucional a partir de um fator exógeno, a mudança da capital federal para Brasília, em 1961(p.75).

Com a vitória do PDT na eleição de 1982, o Rio de Janeiro foi aos poucos agregando outra identidade política, a do brizolismo, que a partir do espaço carioca - de acordo com a intencionalidade política de Brizola e do movimento brizolista proporcionou um jogo político entre o nacional e o local, pois o projeto nacional brizolista permitiria à construção de um paradigma político e administrativo, que o levaria a disputa pelo executivo nacional.

O brizolismo teve no Rio de Janeiro o seu palco principal e, a partir dele, todo o projeto nacional idealizado pela criação do novo partido, o PDT. No seu discurso norteador, a agremiação político-partidária não atuaria somente na escala local, mas sim através de um ideal de Brasil que se fez presente na história, das suas potencialidades e, através do governo do estado, poderiam ser realizadas políticas públicas que evidenciasse as suas características.

Portanto, a metrópole carioca será o espaço em que a narrativa brizolista vai encontrar seu grande eco. Essa afirmação pode ser constatada, através de candidatos posteriores à eleição de 1982, que se elegeram através do brizolismo ou como uma herança de sua cultura política. Sobre esse aspecto, Sento-Sé (1999) afirma ser possível que a cidade do Rio de Janeiro foi reinventada como uma base territorial do brizolismo e "centro de difusão de seu projeto e da sua cultura política" (p.35).

O brizolismo, através da capitalidade e da centralidade do Rio de Janeiro, construiu uma marca política e também espacial. A memória da capitalidade, da representação da unidade, a ideia da cidade como síntese da nação, a reverberação nacional de discussões locais fez com que o brizolismo enquanto movimento político fosse visibilizado nacionalmente. A grande caixa de ressonância, o tambor político de uma nova estética política teve na Cidade Maravilhosa o seu território, além de se tornar uma das marcas identitárias da política carioca e fluminense. 
O brizolismo, com bases fincadas na cidade do Rio de Janeiro, a partir de 1983, apresentou seu campo de atuação em duas a escalas, a local e nacional, fazendo com que, mais uma vez o cenário político carioca seja marcado por essa dubiedade, porém não em uma contradição, já que o local, nesse caso, deveria reverberar no nacional.

Um dos principais ecos do brizolismo na cidade do Rio de Janeiro aconteceu no coração da metrópole carioca, na Praça Floriano Peixoto, conhecida popularmente como Cinelândia. Esse espaço, talvez seja a síntese da capitalidade e da memória da mesma, pois diversos elementos simbólicos ali presentes, constituem um dos lugares de memória do brizolismo. São também dignas de nota que nessa praça, espaço público de muita circulação e convívio, estão expostas algumas formas simbólicas que representam a civilização e o progresso da antiga capital, constituídos pela reforma urbana pela qual a cidade passou no início do século XX.

De acordo com a descrição feita por Azevedo (2016), na Praça Marechal Floriano tem:

\begin{abstract}
(...) quatro instituições metafóricas da civilização ocidental: o Teatro Municipal, significando a ópera, a dança e a música, que com sua imponência e garbosidade representava a alta cultura do Ocidente; a Escola Nacional de Belas Artes, instituição maior das artes plásticas, pintura e escultura, que representavam a tradição de sensibilidade artística da cultura ocidental, além da exaltação da atividade estética como instituto decisivo da noção europeia de civilização; a Biblioteca Nacional, instituição que representava a metáfora da cultura e da atividade científica e intelectual como pilar das civilizações; e o Palácio Monroe, grandiloquente edificação eclética com 56 metros de altura, que foi criado pelo governo federal para a Exposição Internacional de St. Louis, em 1904, e construído no final da nova avenida Central para ser exibido na Conferência Panamericana de 1906, a fim de mostrar aos países do continente a nova capital federal como metonímia do progresso e da civilização. (p.185-186)
\end{abstract}

Foi nesse espaço dotado de historicidade, memória e de valores simbólicos 'da civilização e progresso' que ecoou um dos movimentos mais marcantes e emblemáticos ligados ao brizolismo, conhecido como "Um Grito na Praça", com o objetivo de eleger Brizola governador do estado do Rio de Janeiro. A partir daí, a Cinelândia ganhou uma nova identidade: passou a ser a Brizolândia, um espaço para divulgação das ideias de Brizola e de apoio ao mesmo. Um dos espaços de 
maior centralidade da cidade republicana do século XX “emprestou” sua memória de capitalidade para um movimento político que teve na metrópole carioca seu principal palco de propagação e que fez da "Cidade Maravilhosa" seu grande polo difusor. 


\section{Rio de Janeiro: a cidade "vitrine" do Brizolismo - formas, conteúdos e estratégias espaciais}

No início da década de 1960, a cidade do Rio de Janeiro foi escolhida por Leonel Brizola para ser seu domicílio eleitoral. Já que no ano de 1962, o político gaúcho foi eleito deputado federal pelo antigo estado da Guanabara, tendo a maior votação do Brasil para a cadeira parlamentar nesse ano, marca que continuou persistindo mesmo após as eleições de 1982, em que foi eleito o primeiro governador, por via direta ${ }^{47}$, após a fusão da Guanabara com o estado do Rio de Janeiro.

A campanha política de Brizola se aproximou de amplos setores populares, como os movimentos associativos, principalmente as associações de moradores e os funcionários públicos, segmentos muito relevantes na cidade e no estado do Rio de Janeiro.

O amplo apoio popular representou a conquista de $60 \%$ dos votos válidos no município do Rio de Janeiro e também grande votação nos municípios da periferia imediata, a Baixada Fluminense (ALCKMIM; KUSCHNIR, 2001)

Portanto, em face da configuração política dada pela geografia do voto no estado do Rio de Janeiro (Metrópole e Região Metropolitana com Brizola e o interior com as forças ligadas ao PMDB e ao PDS), a decisão da implementação das políticas públicas do Novo Trabalhismo, sob a lógica discursiva do brizolismo foram iniciadas ${ }^{48}$, como destaca Sento-Sé (1999):

O Rio de Janeiro, mais a capital do que propriamente o estado, é dotado de papel fundamental em toda composição da lógica discursiva brizolista. Muitas das imagens socialmente construídas do Rio de Janeiro, nos últimos anos, tiveram no brizolismo para o bem ou para o mal, um referencial dos mais relevantes. Há uma imagem da antiga capital que é reinventada

\footnotetext{
${ }^{47} \mathrm{O}$ primeiro governo do estado do Rio de Janeiro após a fusão ficou a cargo do Almirante Faria Lima, que foi escolhido diretamente pelo presidente Ernesto Geisel. Já o segundo governador do estado era um velho conhecido da política carioca, que já havia sido governador da Guanabara antes da fusão, Chagas Freitas, que foi eleito por via indireta.

${ }^{48}$ Além da expressiva votação alcançada por Brizola tanto na metrópole quanto na Região Metropolitana é relevante destacar o papel que a cidade do Rio de Janeiro representava para o seu projeto político. Sua eleição permitiu ocupar o território político que significava a "caixa de ressonância do Brasil" e, assim trilhar o seu principal objetivo, o executivo federal.
} 
pelos brizolistas, de modo a fazê-la o centro de difusão e de sua atuação política. (p.35)

O projeto político nacional do PDT, tanto do brizolismo quanto as demais lideranças daquele partido, foi balizado por um discurso radicalizado e antissistema', com o objetivo de mobilizar as massas populares e, convocar seus eleitores, a compor a governança junto ao poder instituído, parceiros e colaboradores do governo que estava se instaurando no estado do Rio de Janeiro a partir de 1983.

A presença de lideranças populares na gestão pública iniciada por Brizola reacendeu a chama participativa em parte da população carioca, condição que foi difundida de formas diversas, muitas vezes depreciativas pelo 'mass media'. Apresentava-se, a partir de então, um grupo populacional 'diferenciado' (favelados, migrantes, mulheres pretas...) no comando de determinadas pastas da gestão indireta e nas assessorias de secretários de governo e da base parlamentar de apoio. Tal composição de suporte direto e indireto à gestão do estado reforçou as territorialidades marginais ${ }^{49}$, da cidade e da região metropolitana no Estado de Direito, trazendo à discussão e o modo como a capitalidade do Rio de Janeiro 'vitrinizava' uma nova composição de forças políticas advindas de bases territoriais subalternizadas, notadamente do escopo urbano, na escala nacional. Portanto, uma nova expressão de capitalidade se esboçava no imaginário público nacional, a partir da política brizolista no Rio de Janeiro.

A seguir destaco alguns personagens importantes que fizeram parte do quadro partidário do PDT. A adesão de muitos deles ao partido fundado por Brizola, tinha relação com as propostas que já estavam estabelecidas pela Carta de Lisboa, que inspirou muitas políticas públicas realizadas pela gestão pedetista no estado e na cidade do Rio de Janeiro.

\footnotetext{
${ }^{49}$ Perlongher (1993) afirma que os territórios marginais são "espaços que reúnem pessoas estigmatizadas e expulsas da sociedade normalizada, as quais se identificam, se relacionam, constroem códigos, normas e estratégias de sobrevivência à margem das normas sociais vigentes".
} 


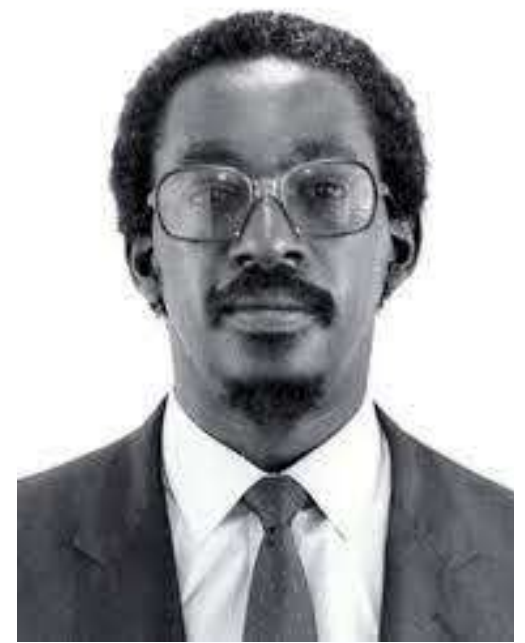

$\mathrm{Na}$ imagem 7: temos o ex-secretário de Habitação do Governo Brizola, Carlos Alberto Oliveira, um dos responsáveis pelo programa "Pra Cada Família, um lote". Foi também autor da lei quando deputado federal, que tornou o racismo crime inafiançável, a chamada Lei Caó. Fonte: camara.leg.br. Acessado em: $30 / 10 / 2021$.

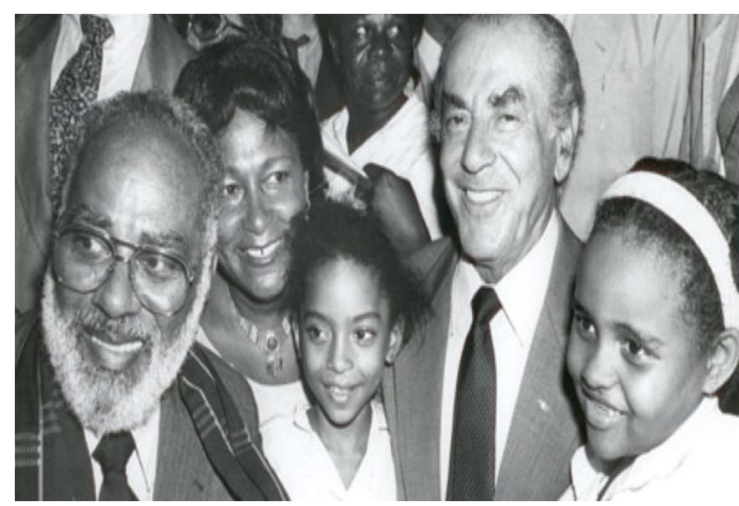

A imagem 9: registra Abdias do Nascimento junto com Leonel Brizola, criador do Teatro Experimental do Negro e uma das lideranças pioneiras do movimento negro no Brasil. Também foi um dos fundadores do movimento negro do Partido Democrático Trabalhista (PDT). Fonte: www.pdt.org.br. Acessado em: $30 / 10 / 2021$.

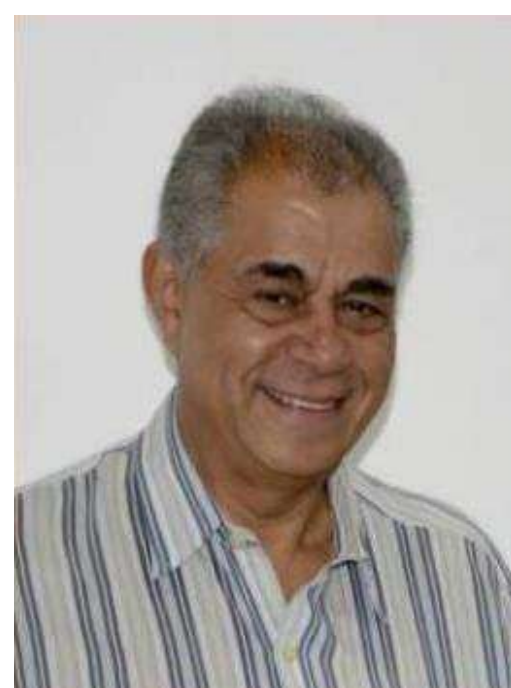

Na imagem 8: temos o vice-prefeito na gestão pedetista de Saturnino Braga, Jó Rezende, que no período era presidente da Federação da Associação de Moradores do Estado do Rio de Janeiro (FAMERJ). Fonte: wikipédia.org. Acessado em: 30/10/2021.

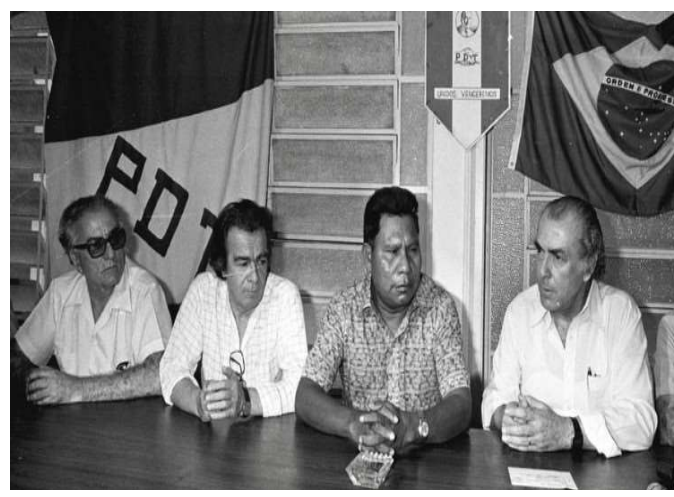

Imagem 10: o cacique Mario Juruna, uma das lideranças das causas indígenas no Brasil, capitaneado pelo PDT, que tinha como um de seus compromissos políticos, estabelecidos na Carta de Lisboa, a luta pela melhoria da qualidade de vida dos indígenas. Fonte: www.pdt.org.br. Acessado em: $30 / 10 / 2021$.

De acordo com a bandeira política brizolista e da formação do PDT, muitas políticas públicas publicizadas na campanha e, posteriormente concretizadas durante o governo de Leonel Brizola no estado do Rio de Janeiro, cooptaram várias lideranças para os quadros políticos do partido. A seguir, um depoimento de Abdias do Nascimento, ativista do movimento negro que corrobora a afirmação:

"Nós temos um socialismo próprio e acho que temos uma grande contribuição a dar ao projeto do socialismo moreno do PDT. Eu 
advogo o socialismo e quero exercê-lo na prática, não só em teorias ou modelos estrangeiros. Temos que colocar todo nosso potencial de luta para que nosso país fique menos racista". (Entrevista concedida a Lula Maia Soares. Abril 1983. Acervo AMORJ. Fundo: PDT.)

As territorialidades aqui indicadas (e projetadas a partir do novo padrão de governança no período brizolista) são entendidas na perspectiva de Sack (1986) em que a territorialidade implica controle, ou seja, a tentativa de imposição de domínio sobre determinada área. A territorialidade como estratégia eficiente de controle sobre recursos e pessoas em determinadas áreas. Nesse sentido, o controle e formação de redutos durante a gestão brizolista foi realizada a partir de suas políticas públicas e pela inserção de atores políticos locais na estrutura de poder que permitiu a governabilidade durante a administração pedetista.

As políticas públicas, direcionadas, em grande parte, a populações marginalizadas, criaram paisagens-marca (BERQUE, 1998) a partir de uma política de representação de uma época. Tais paisagens, mesmo modificadas, deixaram rugosidades nos territórios e na vida social e política de grupos em diversas escalas. No caso do Rio de Janeiro, a capitalidade da cidade, conforme veremos adiante, promoveu uma difusão de novas marcas de gestão popular pelo país, com reverberações na conjuntura e nas políticas públicas atuais, em diversas localidades e esferas da administração pública nacional.

Há também a necessidade de analisar as políticas públicas adotadas durante o governo Brizola (1983-1986), à luz de algumas considerações importantes, que foram mencionadas e que merecem reflexões, pois desde sua campanha política houve por parte de vários setores, como da imprensa, da oposição e do campo progressista, no período, a classificação do discurso e das políticas públicas brizolistas de populista.

Nesse sentido é importante elucidar a visão que recai sobre a atuação de Brizola no governo do estado do Rio de Janeiro afirmada como de cunho populista, por isso é pertinente observar os diferentes usos e sentidos que são feitos sobre essa expressão com relação às plataformas e políticas públicas adotadas pelo brizolismo a partir de 1983. 


\subsection{Rio de Janeiro: capital e espaço de territorialidade da política brizolista}

A eleição de Brizola em 1982 trouxe um novo paradigma para a política do Rio de Janeiro. Tanto na cidade quanto no estado do Rio de Janeiro uma série de discussões de âmbito nacional passou para pauta da esfera política local, ou seja, os debates tinham como tema questões referentes ao país em virtude dos insistentes problemas nacionais como a inflação, a carestia e pobreza estrutural.

Com a inserção na arena política de segmentos do eleitorado antes sem representatividade nas gestões públicas, Sarmento (1998) entende que "o voto em Brizola representava simbolicamente a reversão das estruturas sociais excludentes, com a encenação imaginária do espetáculo da chegada do povo, das massas ao poder". (p.62)

A campanha política polarizada e radicalizada pelo discurso brizolista com relação ao regime e as forças que atuavam no Rio de Janeiro foi uma das explicações para a mobilização de alguns segmentos da população carioca e fluminense, principalmente os setores mais populares e os movimentos de associação de bairros e favelas, que alicerçaram a campanha e, também o governo pedetista.

Sento Sé (2011), por sua vez, afirma que a eleição de Brizola seria um aceno às propostas de regularização da situação fundiária urbana, questão de grande relevância para a população que habitava uma metrópole 'miseropolizada' (SOUZA, 1992). Também Freire (2008) afirma que "o governo pedetista encontrou apoio popular devido ao discurso favorável à luta de moradores de loteamentos irregulares pela regularização de propriedades”. (p.130)

Assim sendo, observa-se que um dos pilares de sustentação política da administração pública do Rio de Janeiro era erguido pelos movimentos de associações de moradores ${ }^{50}$, que tiveram suas pautas defendidas e colocadas como prioridades da política de Brizola. Por conseguinte, uma nova arquitetura política

\footnotetext{
${ }^{50}$ Segundo Freire (2008, p. 131), Brizola teve dificuldades com o movimento sindicalista mesmo que em tese, tivesse boas condições para isso. O movimento conhecido como "novo sindicalismo" já tinha cooptado a maior parte das organizações sindicais existentes no período, por isso Brizola, mesmo com sua figura carismática, não conseguiu apoio dos sindicatos e buscou nos movimentos sociais os pilares de apoio político da administração pedetista tanto no estado quanto no município.
} 
foi construída durante a gestão pedetista, revertendo uma perspectiva política tecnocrática e clientelista de contornos chaguistas, para um 'planejamento participativo' que abriu possibilidades para a formação de novos arranjos políticos e institucionais, influenciando e orientando a formulação, planejamento e execução de políticas públicas populares pela máquina administrativa do estado ${ }^{51}$.

A nova arquitetura política construída abriu canais inclusivos para segmentos marginalizados que faziam parte do tecido social, o que permitiu a cooptação dessas parcelas de população e a formação de redutos políticos e eleitorais, que foram decisivos em eleições posteriores.

Sobre a possibilidade de novos arranjos políticos e institucionais, que permitem maior inserção da sociedade civil na confecção de políticas públicas decisórias, cabe ressaltar a afirmação de Silva (2016):

\begin{abstract}
A arquitetura de gestão territorial e dos instrumentos legitimadores das novas escalas devem reforçar as competências decisórias dos atores civis, com a finalidade de solucionar problemas específicos, sendo estes incorporados a agendas dos poderes públicos reconhecidos (p. 158).
\end{abstract}

A inserção do brizolismo na política carioca e fluminense gerou outra identidade para esses espaços, naquele momento, de 'oposição' ao de Brasília. O oposicionismo instaurado pelo brizolismo caracterizou-se por uma relação participativa no e do poder instituído que, ao mesmo tempo, institucionalizou políticas públicas de cunho social e criou um espaço de ascensão do brizolismo no

\footnotetext{
${ }^{51}$ Há necessidade de as políticas públicas adotadas durante o governo Brizola (1983-1986) serem analisados à luz de algumas reflexões dos discursos sobre o brizolismo. Desde a campanha política de Leonel Brizola houve, por parte de setores, como a imprensa, a oposição e o campo progressista, a classificação das propostas de gestão participativa de 'demagógica' e 'populista'. No caso de Brizola e do brizolismo, a utilização do termo populismo surge na própria tentativa do "caudilho" de reorganizar o PTB. Os opositores tanto a direita quanto a esquerda viam no antigo partido trabalhista pontos que deveriam ser dispensados da política brasileira, como o populismo, o clientelismo, a política de manipulação. Essas classificações não foram diferentes sobre Brizola, durante o período que esteve no executivo do estado do Rio de Janeiro e, também sobre as políticas públicas realizadas em sua gestão. A oposição observava os compromissos da política brizolista, voltada para segmentos mais vulneráveis da população, como populistas, tendo como principal finalidade a cooptação das massas populares. Há, no entanto, questionamentos sobre o termo populismo, na forma como comumente é empregado observados em Debert (1979) Weffort (1965) e Ferreira (2001). Segundo este último autor, existem estudos que refutam a definição clássica de populismo e, conceitos como de circularidade política são mais utilizados. No conceito de circularidade a população não é vista como no prisma do populismo, ou seja, como massa amorfa e inorgânica, mas como partícipe da montagem e da avaliação de políticas públicas e, também das discussões políticas em torno dos problemas e necessidades que envolvem sua condição de vida.
} 
estado do Rio de Janeiro há mais de uma década dominado por uma máquina clientelista muito forte.

Esse novo modelo de gestão que deu origem à formação do brizolismo foi marcado por uma nova disposição política baseada, de acordo com processos de legitimação do poder, a partir da concepção de Weber (1980), de duas formas: a racional-legal e a carismática. De acordo com a primeira concepção tivemos uma nova racionalidade política para o estado do Rio de Janeiro, com a necessidade de institucionalização de outro conteúdo político e, para isso, seria necessária a criação de uma burocracia, não somente com elementos novos, mas que permitisse a governabilidade para a burocracia que estava sendo formada.

No caso do brizolismo a legitimação do poder e da institucionalização de suas políticas públicas, também contou com o carisma. O próprio PDT, pela gênese de formação pode ser classificado como um partido carismático (D’ARAÚJO, 1996). A liderança de Brizola foi importante, pois a adesão ao seu projeto está relacionada a performance discursiva e, através disso tem sua aceitação validada por diferentes segmentos da sociedade, que encontrou na sua liderança uma convergência de símbolos que representam suas necessidades. Nesse sentido, afirmo que uma nova rotinização, deve ser observada de forma processual. Quando me refiro a rotinização parto de um eixo de análise weberiana, em que esse processo de rotinização é (a passagem do extraordinário ao ordinário) e de objetivação, (a passagem do subjetivo/carisma ao objetivo/burocracia) do carisma. (SELL, 2013).

O carisma é uma dimensão societária básica que inclui processos de "institucionalização" e, ao mesmo tempo, de "desinstitucionalização" radical: o carisma é força revolucionária (criativa e destrutiva) da história. (WEBER, 1980) A liderança carismática foi uma das bases de institucionalização política do brizolismo, para que seu projeto de governo fosse alavancado e alcançasse eco entre diferentes representações políticas no espaço fluminense e, principalmente carioca.

Essa nova rotinização marcada pelas duas formas de poder acima elencados rompe com a estabilidade da rotina anterior, relacionado ao primarismo político, tomado no sentido weberiano como uma adesão passional ao líder. 
No esquema quatro procuro evidenciar outra forma de percepção da liderança carismática exercida por Brizola, pois nesse caso o carisma surge através de uma capacidade discursiva que aproxima sua liderança das representações sociais enraizados em um grupo social (SENTO-SÉ, 1999, p. 24).

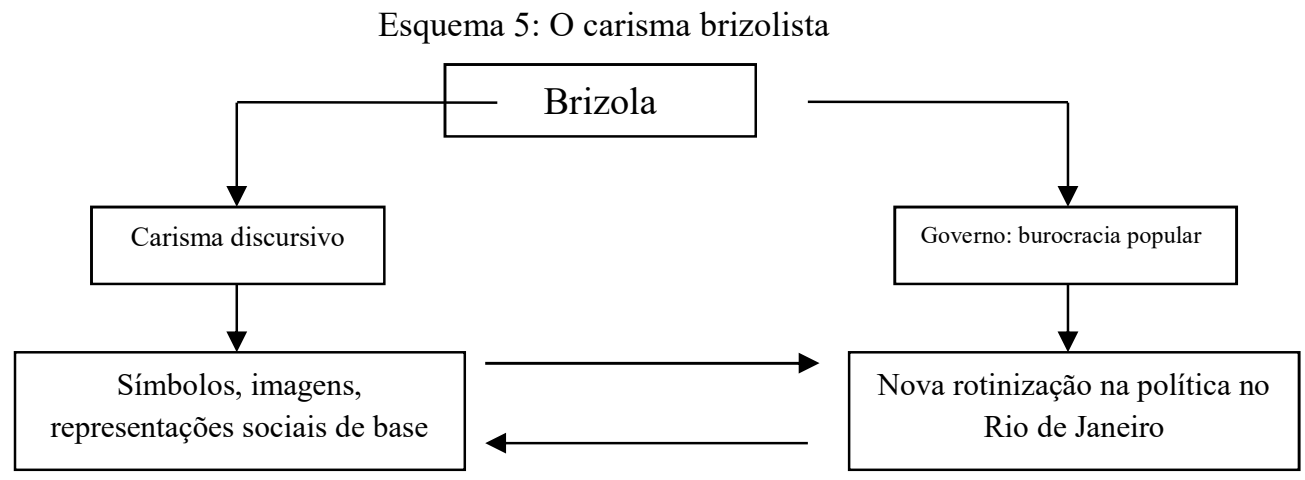

Fonte: elaborado pelo autor, 2021, a partir de Sarmento, 1998.

O esquema acima traduz uma característica sobre o carisma brizolista, pois a liderança exercida por Brizola está vinculada a sua linguagem, como pode ser percebido, no campo discursivo. A linguagem que utilizou criou um campo de representações que permitiu a aproximação com lideranças comunitárias, por exemplo. Ao mesmo tempo a convergência com os movimentos sociais, como as associações de moradores, trouxe outra rotina para a forma de fazer política com a participação mais efetiva destes segmentos no governo e sua legitimação enquanto ator político.

Todavia, outro foco foi dado para o modelo de política vigente no Rio de Janeiro a partir de 1983: a associação do brizolismo com o populismo, adjetivando negativamente tal perspectiva. $\mathrm{O}$ foco dado ao carisma discursivo trouxe, frente a todo esforço de manutenção da governabilidade, grande instabilidade institucional, pois a relação com a base política comunitária e sindicalizada, na aplicação da gestão do Novo Trabalhismo, criava necessárias rupturas com o modelo de governança instituído até então, notadamente em relação à propriedade da terra urbana e ao monopólio das rotas de circulação intra e interurbanas do transporte de massa (ônibus, barcas e trens) ${ }^{52}$. Tais rompimentos criaram barreiras políticas

\footnotetext{
${ }^{52} \mathrm{Na}$ questão envolvendo as empresas de ônibus houve a criação da SMTU (Secretaria Municipal de Transportes Urbanos), com a vitória de Saturnino Braga para prefeitura do Rio de Janeiro. O objetivo era fazer com que o município exercesse maior controle na concessão de linhas de ônibus, política que estava em consonância com a do governo do estado. Outro aspecto importante foi a encampação de empresas de ônibus. Cerca de dezesseis foram encampadas: Redentor, Viação Jabour, Auto
} 
‘intransponíveis' até aquele momento. A partir daí, governabilidade e demagogia passaram a ser concebidas de forma sinônima pela grande mídia e setores afetados diretamente pelas intervenções públicas nos 'foros privados estabelecidos no espaço'.

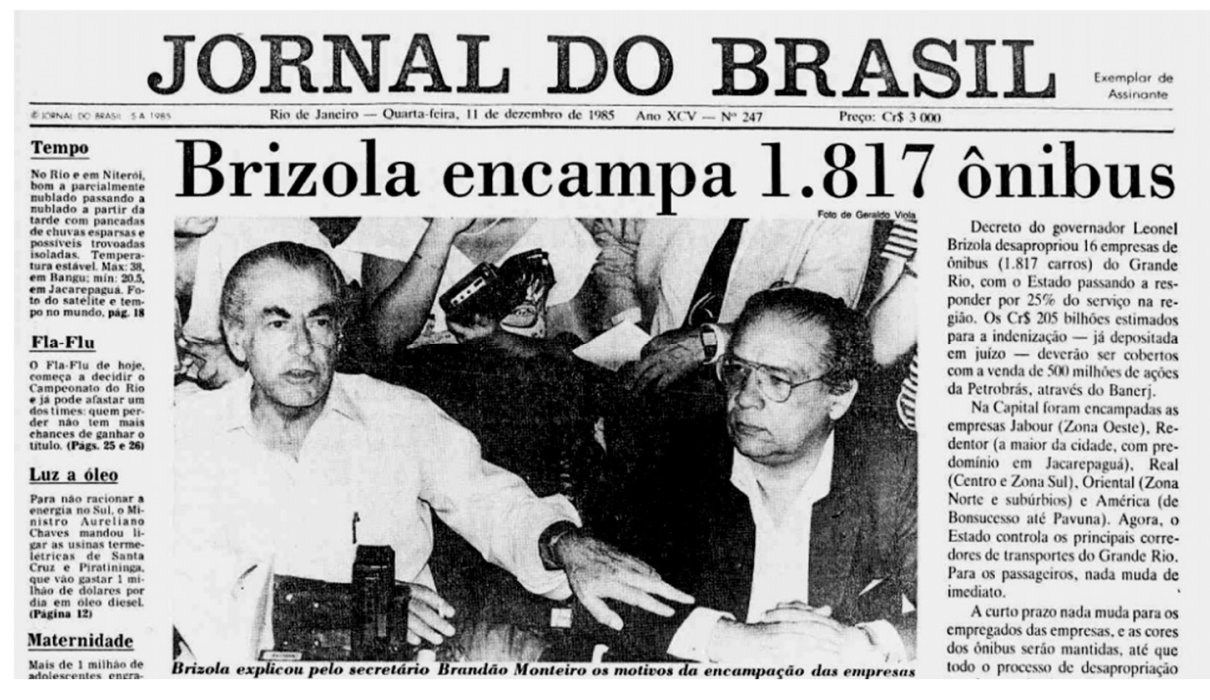

Imagem 11: Brizola contra as empresas de ônibus.

Fonte: www.pdt.org.br. Acessado em: 31/10/2021.

Esse é um tema muito sensível ao brizolismo e, também à figura de Leonel Brizola. Ademais, as práticas de uma pretensa 'política urbana populista e demagógica’ seriam bastante difusas, porém seguiriam um padrão de prestação de serviços às 'camadas sociais mais marginalizadas', espacializadas na metrópole carioca $^{53}$.

As discussões sobre uma pretensa 'nova capitalidade e territorialidade' das políticas públicas brizolistas na cidade criaram 'identidades populares e inclusivas'

Viação Bangu, Real Auto Ônibus e América (essas da cidade do Rio de Janeiro). Na Região Metropolitana: Nilopolitana, Nossa Senhora do Amparo, Estrela de São Gonçalo, Luxor, União, Ponte Coberta, Caravelle, Mageli e Viação ABC. Os principais objetivos eram combater o serviço de turno único nas empresas privadas, oferecer um serviço de qualidade e diminuir tarifas. A CTCRJ (Companhia de Transporte Coletivo do Rio de Janeiro) também ficou responsável pela concessão das linhas de ônibus. Houve também a redistribuição das linhas entre garagens mais próximas para diminuição dos percursos das viagens. As modificações realizadas pelo governo do estado priorizavam as Zonas Norte e Oeste. A Zona Sul era considerada área de menor peso.

${ }^{53}$ É interessante observar que a zona oeste sempre foi um espólio político e eleitoral disputado por amplos segmentos da política carioca. O Chaguismo tinha uma presença forte na zona oeste do Rio. O brizolismo passa a ser institucionalizado nesse território da cidade do Rio de Janeiro, não através de um discurso do clientelismo, mas pela inclusão do associativismo na confecção de políticas públicas. Outros governos disputaram esse espaço, como no período do governo Garotinho, para citar somente um. Atualmente, temos a milícia presente nesse espaço e territorializado, pois boa parte dos bairros que compõe essa região do Rio de Janeiro é dominado pelas milícias, além de grupos ligados a religiões neopentecostais. 
no território que permearam a forma como a gestão desses espaços se deu. Porém tais identidades territorializadas pelo popular e as políticas inclusivas foram duramente atacadas, não só pela mídia hegemônica, naquela época, em torno das informações deturpadas e desabonadoras, mas também pelo 'trabalhismo renovado' de partidos de esquerda, como o próprio Partido dos Trabalhadores (PT) como forma de retomar o discurso nacional do trabalhismo, para a esfera do controle sindical e do desenvolvimentismo industrial baseado no estatismo central.

$\mathrm{Na}$ imagem doze, ficou evidenciado o papel da mídia hegemônica na tentativa de diminuir o impacto das políticas públicas realizadas durante a gestão pedetista no Rio de Janeiro.

\section{"Governador, faça umas escolinhas..." Roberto Marinho tentou fazer Brizola abortar o projeto desde o início}

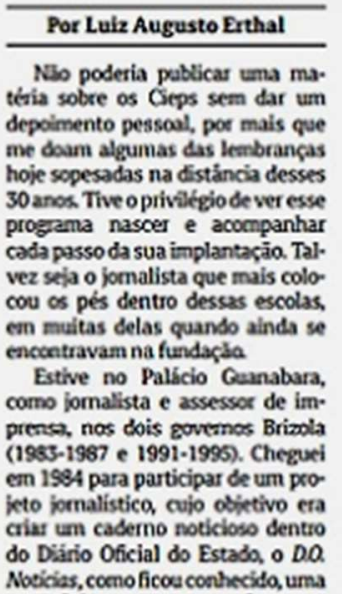

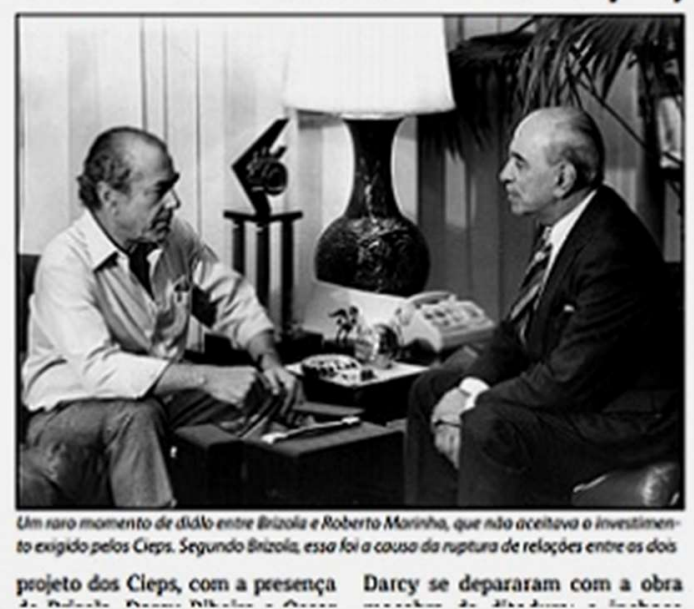

Logo apos o lançamento do programa dos Cieps, Brizola ainda tentou estoicamente obter o apolo do entào presidente das Organldo entáo presidente das OrganiSaçes Gioto, Roberto Marinho Sabla o yuanto ele seria capaz de influenciar, para o bem ou para o mal. Apresentou-lhe pessoalmene o projeto e nos relatou depois: "Ele ollhou, olhou, othou e najo disse uma palavra. Em uma segunda oporturidade em que nos encontramos, eucobrel: Ent la, doutos Roberte, (nto

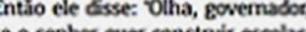
se o senhor quer construir escolas. está muito bem. Mas năo prectisa disso tuda. Fapa umas escolinhas. Pode até fast-las bonitinhas, tipo uns chalezinhos. $\because$ Depois disso ndo houve mais dillogo entre eies. Os Cieps comecaram a brotar do os Cieps comezaram a biotar do chlo com a arquitetura inconfun-

Imagem 12: A mídia contra o projeto dos CIEPs.

Fonte: pragmatismopolitico.com.br. Acessado em: 31/10/2021

Segundo Weffort, 1965:

O populismo seria uma crise nas modalidades "tradicionais" de atuação das elites políticas e, por isso, abertura de novas possibilidades de participação popular. O populismo não poderia ser reduzido a uma relação carismática ${ }^{54}$, mas seria a expressão política das dificuldades das classes sociais em ir além da "tradição". Caberia aos seus intérpretes, portanto, não

\footnotetext{
${ }^{54}$ Vai ser nesse aspecto que o chamado "Novo Sindicalismo", que estava radicado no Partido dos Trabalhadores, vai ter reservas as políticas adotadas pelo brizolismo e para o chamado "Novo Trabalhismo". Na cabeça do grupo do ABC paulista, as diretrizes políticas apontadas por Brizola eram um retrocesso, um retorno a política petebista e varguista, em que os trabalhadores não tinham autonomia e os sindicatos eram atrelados ao governo, através de suas lideranças. É interessante notar, que um dos pontos de discórdia entre Brizola e os integrantes do "Novo Sindicalismo" era que o líder pedetista era contra a chamada contribuição sindical.
} 
compactuar com esse viés ideológico, mas contribuir para ajustar em termos científicos a "percepção" dos "homens de ação" para a realidade política brasileira. (p.164 e 171)

Os fatores que explicam a ênfase em atacar ou colocar as práticas políticas adotadas pelo governo pedetista como populista, deveu-se em grande parte ao projeto da Carta de Lisboa, que enfatizava o nacionalismo na base do homem comum (e não do 'proletário' industrial), em uma concepção de trabalho que sai da esfera do industrialismo paulista para a terceirização precária da população carioca. A opção de Brizola pelos 'mais pobres' e desqualificados para o mundo do trabalho industrial se chocava com a perspectiva industrial-desenvolvimentista encampada pelo PT, à época, e a rejeição ao Novo Trabalhismo pela pequena classe média forjada no industrialismo paulistano do $\mathrm{ABC}$ rendiam críticas ao pretenso 'arcaísmo populista' identificado nos discursos de Brizola, mesmo se este tivesse uma clara percepção de que a dependência do país estava associada às "perdas internacionais geradas pelas trocas desiguais". Atualmente, os partidos de esquerda no campo das 'ideias progressistas' tentam atrair para a sua esfera discursiva a 'opção pelos mais pobres, das mulheres e das minorias' como Brizola discursava na década de 1980 .

Classificar a gestão pedetista entre 1983 e 1986, como populista ${ }^{55}$ é fazer referência a noção mais comum de manipulação social através de práticas 'arcaicas'

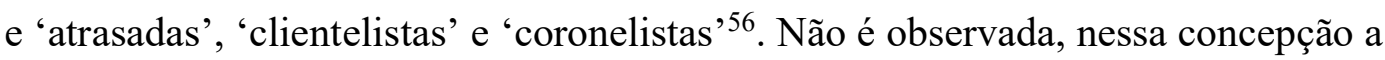
participação efetiva da população na vida política, mas somente vista como uma massa amorfa, portanto, manipulável, em outros termos, não há circularidade política. O eleitor e a população não são agentes do processo, somente receptores passivos dos discursos e práticas instituídas.

\footnotetext{
${ }^{55}$ Segundo Worsley (1970) existem quatro principais manifestações em que o termo populismo é atribuído: 1 - ao movimento russo "narodnik"; 2 - aos movimentos americanos nas regiões rurais do sul e do oeste, em fins do século XIX; certos movimentos e certos tipos de Estado da África, Ásia e América Latina e; a movimentos e ideologias de toda espécie que se baseiam, por um lado, a noção de vontade do povo.

${ }^{56}$ Weffort, 1965, p. 176, faz uma distinção entre populismo e coronelismo. Para este autor são fenômenos distintos. No coronelismo temos contatos nos limites sociais e econômicos sob o domínio do senhor rural; a adesão da massa ao líder supõe, ao contrário, a liberdade econômica daquele tipo. No coronelismo a relação é quase política, é apenas uma dimensão da dependência social e geral do eleitor; no populismo a relação política é frequentemente a única; no coronelismo exprime um compromisso entre o poder público e o poder privado; o populismo é, no essencial, a exaltação do poder do Estado se colocando através do líder, em contato direto com os indivíduos reunidos na massa.
} 
O modo de governança adotado por Brizola poderia ser classificado como de circularidade política, no que se refere à participação popular que enfatiza uma forma distinta do populismo. No modelo de populismo referido a Brizola, haveria o controle efetivo das massas por uma liderança específica, cuja força impediria a mesma, o poder decisório e capacidade de mobilização e de integração. Não há um retorno a partir dos desejos da população, nas políticas públicas implementadas pelos atores governamentais; já na circularidade política, as políticas públicas são avaliadas por quem as recebe e grande parte delas montadas pela participação popular no processo de governança. Leonel Brizola no programa Roda Viva da TV Educativa, em 1997 mostra a inadequação da classificação do seu governo de 'populista' de forma irônica. Segundo o ex-governador, "se fazer políticas que favorecem as populações mais pobres significa ser populista, então sou um populista".

A partir da implementação de políticas públicas por Brizola, falar de uma capitalidade e de uma territorialidade a partir do brizolismo é considerar as ações e a forma de fazer política no estado do Rio de Janeiro a partir da ascensão do líder trabalhista nesse espaço, formando uma nova identidade, com um conteúdo específico. Diante do exposto, muitas imagens foram construídas, discutidas e, até mesmo estigmatizadas sobre o governo pedetista e as políticas públicas realizadas durante sua gestão na unidade da federação citada.

O espaço carioca e fluminense passou a ter no brizolismo um referencial tanto para o bem quanto para o mal na sua gestão, pois determinadas práticas exercidas nesse período tiveram continuidades em governos posteriores, não necessariamente brizolistas, mas que utilizaram políticas públicas semelhantes.

Abordar, a capitalidade e uma territorialidade a partir do brizolismo é considerar as políticas públicas e uma nova fisionomia política no Rio de Janeiro nos anos 1980. Esse modelo de governança criou uma identidade diferenciada para metrópole carioca. Os espaços, tanto carioca quanto fluminense, passaram a ter no brizolismo determinadas práticas exercidas naquele período que tiveram 
continuidades em governos posteriores, não necessariamente brizolistas, mas que utilizaram discursos e políticas semelhantes ${ }^{57}$.

É importante aqui frisar que a construção de uma nova capitalidade para o Rio de Janeiro pelo brizolismo foi concretizada nos territórios fluminense e carioca através dos objetivos das políticas públicas adotadas. O projeto brizolista de educação foi o que mais deu projeção aos seus governos. De caráter nacionalista e como projeto civilizador, a universalização do ensino era vista como principal base de mudanças na sociedade, ou seja, seria um processo civilizador e emancipatório, que reverteria os caminhos trilhados pelo país (Bomeny, 1998).

Assim, o estado do Rio de Janeiro e, principalmente a metrópole carioca tem um caráter metonímico em relação ao Brasil, através de um projeto (o educacional) que gerou um impacto político de cunho nacional, por seu viés emancipatório. Essa marca do governo Brizola na Cidade Maravilhosa seria o famoso "tambor político" que se almejava como projeto para a ascensão do PDT, partido que se identificava com o trabalhismo renovado, alçado nacionalmente pelo polo irradiador do país.

Tal condição reforçaria uma nova capitalidade para o Rio de Janeiro, pois através da legitimação de uma política educacional de caráter civilizatório o Brasil constituiria um sistema de educação capaz de fazer sentido à lógica nacionalista e autônoma no sentido proposto pela Carta de Lisboa para a emancipação dos povos. Sento-Sé (1999) indica que o projeto civilizador de Brizola tinha um tripé bem definido: 1) a difusão da cultura erudita através da universalização do ensino; 2) a vontade, sofisticação e burocratização do Estado e; 3) o crescimento das camadas médias. (p.125)

A nova capitalidade da cidade do Rio de Janeiro surgida por uma 'estética política' direcionada por Leonel Brizola em 1983 costura o novo trabalhismo que se buscava implantar no Brasil com influencia da socialdemocracia europeia. Nesse sentido, é importante frisar que tal concepção de civilização significava, em termos concretos, uma melhor equidade em termos de divisão de recursos no país, já

\footnotetext{
${ }^{57}$ Dentre essas políticas públicas menciono o Projeto Favela Bairro, que fez parte das prefeituras de César Maia e Luiz Paulo Conde, o projeto dos CIACs (Centro Integrado de Atividades Complementares), este no governo Fernando Collor, porém esse projeto contou com a colaboração de Darcy Ribeiro. Mesmo sendo oposição a Collor, Brizola apoiou o projeto. Na prefeitura de Eduardo Paes, tivemos as Escolas do Amanhã.
} 
assolado à época pela imensa desigualdade de acesso à renda. Assim sendo, dentro dos trâmites da tradicional socialdemocracia europeia, de base alemã e escandinava, ampliar o distributivismo entre as classes sociais significava criar diferentes padrões de cobrança de impostos em que 'quem tem mais paga mais impostos e quem ganha menos paga menos ou não paga'. Tal discurso será encampado por linhas partidárias de centro-esquerda no país, como o que fundou o Partido da Social Democracia Brasileira (PSDB) em 1988.

A capitalidade da cidade do Rio de Janeiro surgiu através de uma nova estética política, que foi inaugurada com a posse de Leonel Brizola em 1983, que trouxe um discurso de uma política tradicional, porém renovada, através da costura do trabalhismo com a socialdemocracia europeia e que, utilizando as palavras de Azevedo (2016), a cidade, no caso a "Maravilhosa" vai consagrar uma nova forma de fazer política em que teremos nesse território uma referência para determinadas políticas públicas, que seriam adotadas por diferentes governos brasileiros ${ }^{58}$.

Nessa perspectiva, abro um parêntese para observar o programa do Partido da Social Democracia Brasileira (PSDB). Consultando os programas e diretrizes doutrinárias sobre os Partidos Políticos Brasileiros (2013-2014) o PSDB enfatiza como objetivos programáticos a consolidação dos direitos individuais e coletivos; o exercício democrático participativo e representativo; a soberania nacional; a constituição de uma ordem social justa e garantida pela igualdade de oportunidades; o respeito ao pluralismo de ideias, culturas e etnias; as diferentes orientações sexuais e identidades de gênero e a realização do desenvolvimento de forma harmoniosa, com prevalência do trabalho sobre o capital, buscando a distribuição equilibrada de riquezas. (p.133)

Há, nos objetivos programáticos do PSDB muitos conteúdos que já estavam presente na formação do Partido Democrático Trabalhista. Fica clara a incorporação

\footnotetext{
${ }^{58}$ Alguns governos, em diferentes escalas utilizaram políticas, ou melhor, implementaram políticas públicas que têm no brizolismo sua gênese, dentre elas podemos citar a criação dos CIACs (centro Integrado de Atendimento a Criança), criado na gestão do presidente Fernando Collor de Melo, rival político de Brizola, porém teve o apoio deste e, também de Darcy Ribeiro. A opção pela urbanização de favelas também se tornou presente por prefeituras durante a década de 1990, como foi o caso do Programa Favela-Bairro, de urbanização das favelas na cidade do Rio de Janeiro, durante as gestões de César Maia e Luiz Paulo Conde. Tivemos também, durante a gestão de Eduardo Paes a construção das chamadas Escolas do Amanhã, que seria uma possibilidade ou tentativa de formular uma educação em tempo integral.
} 
da agenda pedetista no projeto político tucano. A plataforma discursiva apresenta pontos muito semelhantes ao documento fundador pedetista, no entanto a aceitação das duas propostas político partidárias não foi a mesma forma. Alguns fatores podem explicar essa diferenciação por parte do establishment, como a "ênfase na questão administrativa e na reforma do Estado (programa de desestatização e Lei de Responsabilidade Fiscal), com a reformulação de seu programa após o Plano Real". A nova agenda preconizava "mais mercado e mais inserção na economia global” (PARTIDOS POLÍTICOS BRASILEIROS, 2013-2014).

Levando-se em consideração as afirmações de Roncayolo (1986), para quem a territorialidade está baseada em duas funções complementares: uma positiva de relação com determinada área (a construção do território) e outra negativa de relação com indivíduos de outras áreas (a competição entre territórios) e também a definição de Sack (1986), para quem a territorialidade é firmada de diversas maneiras, como, por exemplo, os direitos legais de um país sobre determinada área, ou a apropriação e defesa de um território através do recurso à força bruta ou pelas normas culturais, mas também pelas formas mais sutis de comunicação, pode-se compreender a estratégia espacial do brizolismo para que sua política fosse institucionalizada. Dentro dessa perspectiva de estratégia espacial, destacamos aqui o controle de regiões da cidade menos atendidas pelos serviços públicos como a zona oeste e as favelas, que se dava pelo entendimento das práticas culturais de seus habitantes e dos discursos e de ações concretas que legaram à cidade formas e marcas espaciais. Para tanto, grupos locais foram cooptados pela participação direta e indireta na esfera pública, a partir de uma montagem associativa de uma agenda que atendesse às suas demandas. Outrossim, tais componentes de territorialidade criaram cismas territoriais e conflitos entre as regiões da cidade.

Reis, 2009 reforça essa ideia quando ao indicar que:

As dinâmicas dos espaços não são somente resultado de uma única lógica de cálculo e de racionalidade, nem de uma forma exclusiva de governação (a do mercado), estando também diretamente vinculado a cultura, sistema de valores, hábitos, rotinas, regras e instituições. 
Quanto a argumentação de Reis (2009), entende-se a formação de uma territorialidade brizolista (e do brizolismo) a partir do "alargamento institucional", pois como já observado, as instituições não estão circunscritas somente a normas, regras, leis e organização do Estado, mas também por outras construções sociais que influenciam comportamentos de atores políticos, através de variáveis como 'regras informais' e formas de conduta e de cultura política diferenciadas.

Brizola encontrou uma forma de manter sua governabilidade e legitimidade para implementação de suas políticas públicas mediante a cooptação ${ }^{59}$ de determinados segmentos da sociedade. De acordo com as considerações de Debert (1979):

Em Brizola o chefe do executivo, enquanto pessoa do orador, ocupa lugar de sujeito da transformação, e a relação deste com o povo é uma relação direta, sem mediação de nenhuma instituição. $\mathrm{O}$ povo tem lugar de destinador, aparece como suporte da verdade, a fonte do saber político, o critério para determinação da autenticidade das elites, que uma vez por ele escolhidas, ocupam lugar de sujeito da transformação. (p.140-1)

No sentido apresentado por Debert (1979), a possibilidade de classificar como populista a aliança do governo Brizola com a massa 'cai por terra' da mesma forma que a leitura de que o discurso do líder do PDT representava uma política do atraso, como forma simples de cooptação pela manipulação de uma liderança política. Pois o que ele fez foi criar um espaço aberto que permitiu a participação popular em seu governo. O público principal das políticas adotadas pelo brizolismo definiu, de forma mais transparente, um espaço que reconhecido como um ambiente em que suas reivindicações e pautas pudessem ser incorporadas a um projeto de governo, ou melhor, a um projeto de Estado.

\subsection{A Carta de Lisboa: documento matriz das políticas brizolistas que deixaram marcas nos espaços carioca e fluminense}

O brizolismo não é somente um movimento político que teve no Rio de Janeiro seu território de maior repercussão no país. A partir de 1983 deixou marcas

\footnotetext{
${ }^{59}$ Utilizo o termo cooptação nesse caso, não como uma forma de manipulação das massas, mas na necessidade de ter o apoio popular e conseguir institucionalizar seu projeto de governo. Nesse projeto, vamos ter muitas políticas que foram apresentadas como forma de alavancar o seu projeto nacional, criando uma visibilidade para seu governo que foram espacializadas no território fluminense e, principalmente carioca.
} 
na metrópole carioca, concretizadas por políticas públicas que persistiram ao longo das últimas décadas. Minha assertiva parte do princípio de que qualquer análise sobre a metrópole carioca tanto na política eleitoral quanto nas ações praticadas pelos últimos governos carregaram alguma influência do brizolismo.

Analisar as políticas brizolistas durante os períodos em que Brizola esteve à frente do executivo do estado do Rio de Janeiro é também observar como o documento fundador do Novo Trabalhismo, a Carta de Lisboa, serviu como matriz ideológica e de governança para a confecção de políticas públicas comprometidas com as diretrizes e o plano de ação político do Partido Democrático Brasileiro (PDT).

A Carta de Lisboa construiu a matriz ideológica e formativa que permitiu a criação dos pressupostos básicos que nortearam o governo Brizola, e delimitou, na tentativa de buscar uma coerência entre a política e a prática política, as competências norteadoras das ações praticadas no período pedetista.

Como ressaltado na seção anterior, grande parte das políticas públicas realizadas durante o governo Brizola, contou com o respaldo e participação de parcelas significativas de segmentos da população, na sua maior parte, os menos favorecidos e 'miseropolizados' (SOUZA, 1992). Destaco um trecho da Carta de Lisboa que corrobora com o afirmado em que "o novo, importante e fundamental, é a emergência do povo trabalhador na vida política do País, com o objetivo de lutar pelos seus direitos e pela democracia" (PARTIDO DEMOCRÁTICO TRABALHISTA, 2006).

Diante do exposto, procuro, nesta seção, analisar sob uma perspectiva espacial, as marcas territorializadas no estado do Rio de Janeiro, que teve na Carta de Lisboa a matriz fundamental para realização de políticas públicas na gestão pedetista. Um dos pontos de partida para estudar o brizolismo no Rio de Janeiro e suas marcas, está respaldado na dinâmica espacial proposta por Berque (1998), em que este autor classifica a paisagem através do par dialético marca e matriz. Para ele, "a paisagem é uma marca, na medida em que expressa uma civilização, e é também matriz, pois participa dos esquemas de percepção, de concepção e de ação que canalizam a relação de uma sociedade com o espaço e com a natureza" (p.178). 
A partir das concepções de marca e matriz, buscaremos mostrar que é possível descrever e inventariar elementos presentes nos espaços carioca e fluminense, partindo de uma metodologia em que é possível quantificar formas e conjuntos de formas, que exprimem, concretamente, as políticas públicas realizadas durante o governo brizolista, portanto, as suas marcas.

Partindo das considerações desse esquema de percepção o brizolismo no Rio de Janeiro também vai ser matriz, pois vamos ter uma concepção e ação, além de uma consciência estética, moral e política do movimento. A emersão de uma nova cultura política na unidade da federação citada pode ser considerada uma mudança de paradigma que determinou outra experiência e também ação.

Destacamos que uma análise espacial com relação ao tema proposto pressupõe uma concepção de poder, dado nesse caso através da ação política realizada no governo pedetista, pela capacidade discursiva e de cooptação de sua liderança principal; porém, o mais importante foram as políticas públicas que buscavam atender determinados segmentos populares da sociedade com o objetivos de retirá-los da marginalidade e da exclusão.

Quanto às marcas podemos nos remeter a discussão sobre as formas simbólicas, privilegiando a dimensão espacial que estas podem apresentar. Segundo Correa (2007, p. 7), “as formas simbólicas dão visibilidade a um importante aspecto da espacialidade da ação humana, que é marcada não apenas por uma perspectiva econômica, mas também por um simbolismo que marca e influencia as demais dimensões dessa espacialidade".

O esquema proposto por Berque de marca e matriz remete-nos à ideia de recursividade em Morin $^{60}$ (2005), pois as marcas introduzidas no espaço, como formas simbólicas que traduzem um determinado pensamento ou viés político, são um produto, portanto fruto de uma ação de uma determinada cultura que evidencia um projeto de poder, porém ao mesmo tempo, o espaço em que essas marcas são

\footnotetext{
${ }^{60} \mathrm{~A}$ ideia de recursividade explicitada no movimento constituído pela concepção dinâmica da tríade parte do princípio do círculo recursivo proposto por Morin (2000). Para o autor, a recursividade é a ideia que traduz os conceitos de autoprodução e auto-organização. O movimento dinâmico da tríade se faz recursivo por sua característica geradora, na qual seus produtos e os seus efeitos são eles próprios causadores do que os gera e/ou produz.
} 
territorializadas, é matriz, autoproduz uma concepção e ação política fruto de uma nova percepção e concepção de políticas públicas.

Conforme nos evidencia Rowntree e Conley, (1980), "as formas simbólicas apresentam um sentido político, portanto são carregadas de intencionalidade, tornando-se mecanismos regulatórios de informações que controlam significados" (p.465)

As formas simbólicas presentes no espaço, cobertas por uma intencionalidade, são criadas com um propósito específico, portanto apresentam um caráter político, mas também pedagógico na medida em que refletem um projeto político e institucional, através de suas marcas e formas simbólicas espacializadas por políticas públicas adotadas fornecendo a imagem que se quer visibilizar pelo governo. As marcas e formas simbólicas fazem com que sejam percebidas espacialmente a concepção e ação política e institucional que um determinado grupo pretende colocar em prática através de um planejamento com um viés estético e moral que procura imprimir no espaço suas características.

Segundo Correa (1997) as formas simbólicas são concebidas com o propósito de realizar algumas funções e essas formas, socialmente produzidas estão imersas na vida política. A partir disso, segundo o autor, foram elencadas as seguintes funções, tais como:

i. Glorificar o passado, acentuando alguns aspectos julgados relevantes para o presente e o futuro;

ii. Reconstruir o passado, conferindo-lhe novos significados. Neste caso, como no anterior, tradições podem ser inventadas, como argumentam Hobsbawm e Ranger (2002);

iii. Transmitir valores de um grupo como se fossem de todos. Nesse caso estão envolvidas fortes relações de poder;

iv. Afirmar a identidade de um grupo religioso, étnico, racial ou social. A identidade nacional tem sido objeto de inúmeras formas simbólicas;

v. Sugerir que o futuro já chegou, sendo portador de características julgadas positivas;

vi. Criar "lugares de memória", cuja função é a de estabelecer ou manter a coesão social em torno de um passado comum (NORA, 1989, p.7-25). 
Tendo em vista as funções apresentadas acerca das formas simbólicas, é possível fazer uma aproximação com o projeto de governo brizolista. A primeira função foi a recuperação das políticas reformistas e trabalhistas, o fio da história que norteou o projeto do novo trabalhismo proposto por Brizola. Com relação à segunda função, temos a reconstrução do passado, assumindo novos significados, com a inserção de temas relacionados à socialdemocracia europeia e a inclusão do direito das minorias em seu projeto, elencado na Carta de Lisboa.

O projeto do brizolismo, dentro de uma visão civilizatória ${ }^{61}$, tem como exemplo, a emancipação do povo através da educação, procurou transmitir valores baseados no trabalhismo renovado e no nacionalismo. Através dessas diretrizes se buscou reformas tanto de âmbito estrutural quanto institucional. O trabalhismo brizolista seria o caminho para o chamado socialismo democrático, sendo um projeto de futuro. Além disso, essa forma de concepção do trabalhismo incorporou um discurso que enfatizou a pluralidade, pois trouxe para o debate políticopartidário os diversos conflitos como o das minorias.

Nesse contexto, o brizolismo pode ser encarado como um projeto emancipador a partir de um trabalhismo redefinido, apoiado no nacionalismo e na socialdemocracia. A emancipação, portanto, viria, de acordo com a Carta de Lisboa, através "da construção de uma sociedade democrática da convocação de forças comprometidas com os interesses dos oprimidos, dos marginalizados e de todos os trabalhadores brasileiros e na identificação com as causas populares". (CARTA DE LISBOA - PDT, p.8)

Partindo do conteúdo proposto pelo documento fundador do Novo Trabalhismo, Brizola criou mais que um projeto de governo, na verdade um projeto de Estado que teve nos espaços carioca e fluminense o seu grande 'laboratório', a base experimental, com a finalidade principal de tornar suas políticas públicas um modelo do que poderia ser realizado caso alcançasse o executivo nacional. Com isso, o projeto de administração pedetista ganhou visibilidade através das suas políticas públicas que serão analisadas através do par dialético marca e matriz concretizados na paisagem carioca e fluminense. De acordo com a análise das

\footnotetext{
${ }^{61}$ Sento-Sé (1999) estabelece "quatro elementos importantes para a análise como projeto civilizador brizolista: a difusão da cultura erudita através da universalização do ensino, à vontade, a sofisticação e burocratização do estado e o crescimento das camadas médias".
} 
políticas públicas adotadas pelo governo Brizola e dentro da formulação de um projeto de cunho nacional, foi elaborado um quadro que sintetiza as principais marcas e matrizes que puderam ser inventariados e mostram algumas das concepções e ações políticas dessa gestão do espaço.

Quadro 5: Marcas e Matrizes da política brizolista

\begin{tabular}{|c|c|c|c|}
\hline Políticas & Marcas & $\begin{array}{l}\text { Matrizes (a partir da } \\
\text { Carta de Lisboa) }\end{array}$ & Objetivos \\
\hline $\begin{array}{l}\text { Programa } \\
\text { Educação }\end{array}$ & $\begin{array}{l}\text { Centro Integrado de } \\
\text { Educação Pública e a } \\
\text { Passarela do Samba*. }\end{array}$ & $\begin{array}{l}\text { Mudanças nas diretrizes } \\
\text { econômicas, tendo como } \\
\text { prioridade às necessidades } \\
\text { vitais, dentre elas a educação. }\left(3^{\circ}\right. \\
\text { Compromisso da Carta de } \\
\text { Lisboa) }\end{array}$ & $\begin{array}{lr}\text { Erradicar } & 0 \\
\text { analfabetismo, melhorar } \\
\text { a qualidade do ensino } \\
\text { público, promover } \\
\text { assistência social aos } \\
\text { estudantes. }\end{array}$ \\
\hline Cada Família, um lote & $\begin{array}{l}\text { Propriedade para cerca de } \\
18000 \text { famílias, }\end{array}$ & $\begin{array}{l}\text { Mudanças nas diretrizes } \\
\text { econômicas, tendo como } \\
\text { prioridade às necessidades } \\
\text { vitais, nesse caso a habitação. }\left(3^{\circ}\right. \\
\begin{array}{l}\text { Compromisso da Carta de } \\
\text { Lisboa) }\end{array} \text {. }\end{array}$ & $\begin{array}{l}\text { Regularização fundiária, } \\
\text { fim da política } \\
\text { remocionista } \\
\text { urbanização das favelas. }\end{array}$ \\
\hline PROFACE & $\begin{array}{l}\text { Saneamento básico em } \\
\text { favelas e melhoria na } \\
\text { coleta de lixo. }\end{array}$ & $\begin{array}{l}\text { Relacionado ao } 3^{\circ} \text { compromisso } \\
\text { da Carta de Lisboa. }\end{array}$ & $\begin{array}{l}\text { Melhoria da qualidade de } \\
\text { vida e a inclusão das } \\
\text { favelas na vida urbana } \\
\text { regular }\end{array}$ \\
\hline Uma Luz na escuridão & $\begin{array}{l}\text { Energia elétrica nas } \\
\text { favelas }\end{array}$ & $\begin{array}{l}\text { Relacionado ao } 3^{\circ} \text { compromisso } \\
\text { da Carta de Lisboa. }\end{array}$ & $\begin{array}{lr}\text { Melhoria } & \text { na } \\
\text { infraestrutura } & \text { dos } \\
\text { serviços de } & \text { segurança } \\
\text { pública. } & \end{array}$ \\
\hline $\begin{array}{ll}\text { Projeto } & \text { Mutirão } \\
\text { Comunitário } & \end{array}$ & $\begin{array}{l}\text { Melhoramentos na } \\
\text { infraestrutura de espaços } \\
\text { como as favelas com a } \\
\text { utilização de mão de obra } \\
\text { local. }\end{array}$ & $\begin{array}{l}\text { Relacionado ao } 3^{\circ} \text { compromisso } \\
\text { da Carta de Lisboa e ao } 2^{\circ} \\
\text { Objetivo (o debate para solução } \\
\text { de problemas deve ter a } \\
\text { participação de todos). }\end{array}$ & $\begin{array}{l}\text { Melhoria da qualidade de } \\
\text { vida e integração do } \\
\text { movimento associativista } \\
\text { com os órgãos públicos. } \\
\text { Maior envolvimento da } \\
\text { população local com a } \\
\text { estrutura política. }\end{array}$ \\
\hline $\begin{array}{l}\text { Fim da política do "pé } \\
\text { na porta" }\end{array}$ & $\begin{array}{lr}\text { Criação do } & \text { Conselho de } \\
\text { Justiça, } & \text { Segurança } \\
\text { Pública e } & \text { Direitos } \\
\text { Humanos. } & \text { Segurança } \\
\text { preventiva, Policiamento } \\
\text { comunitário. }\end{array}$ & $\begin{array}{l}\text { Parte do } 3^{\circ} \text { Plano de Ação da } \\
\text { Carta de Lisboa. Lutar contra a } \\
\text { justiça opressiva, a humanização } \\
\text { da segurança pública e a não } \\
\text { violação dos direitos humanos. }\end{array}$ & $\begin{array}{l}\text { Segurança pública com } \\
\text { respeito à segurança } \\
\text { pública, inviolabilidade } \\
\text { da propriedade privada. }\end{array}$ \\
\hline
\end{tabular}

Fonte: elaborado pelo autor, 2021.

* No projeto da Passarela do Samba havia 160 salas de aula, 43 salas administrativas, pré-escolas, $1^{\circ}$ grau integral (hoje Ensino Fundamental), $2^{\circ}$ Grau (Ensino Médio), formação de professores, quadras de esportes e bibliotecas. Funcionavam como escola durante o ano letivo e, durante o carnaval se tornava o principal palco dos festejos carnavalescos do Rio de Janeiro (BOMENY, 1998). 
Uma análise do quadro possibilita tirar algumas conclusões com relação à concepção da orientação política que o governo eleito em 1982 apresentava.

A primeira delas é que ficam claras que as principais ações estavam voltadas para um projeto político tendo como público-alvo primordial as populações classificadas como carentes ou vulneráveis, não somente através de programas, mas também da própria participação popular no processo. Outro aspecto importante é que no seu projeto as aspirações populares influenciaram bastante o programa de governo pedetista.

As políticas públicas ilustradas no quadro da página anterior fazem parte de dois programas que nortearam a sua formulação: O Plano de Desenvolvimento Econômico e Social do estado do Rio de Janeiro, com um escopo amplo de atuação e teve como objetivo, dirimir os problemas socioeconômicos que afligiam principalmente os mais carentes. A seguir destaco alguns pontos do Plano:

- Melhoria das condições dos trabalhadores, através da habitação, saneamento, transporte, assistência médica, escolas, emprego.

- Controle do uso do solo urbano, para conter a violência social.

- Reconhecimento dos direitos dos que na terra habitam e trabalham.

- Fortalecimento das economias locais, absorvedoras de mão de obra, principalmente da periferia da Região Metropolitana.

- Definição de critérios que contemplam adequadamente as formas de adensamento populacional e intensificação do uso do solo urbano das áreas já congestionadas.

- Fortalecimento do poder municipal, para o desenvolvimento local. Estreitamento da cooperação entre estados e municípios e municípios entre si.

- O estabelecimento de bases de participação da comunidade e acompanhamento das iniciativas governamentais. (NEVES, 2007)

Outro programa igualmente importante foi o Programa Especial de Educação (PEE, Lei 705/1983). Segundo Bomeny (1998) contava ao todo com 
dezenove metas ${ }^{62}$ e seu processo foi realizado de forma democrática, com participação de professores de vários municípios do estado, tendo como marco inicial o I Encontro de Professores de $1^{\circ} \mathrm{Grau}$ (p.99). O Encontro de Mendes reuniu professores para discutir as políticas educacionais do governo do estado. Nessa assembleia foi criado o projeto dos Centros Integrados de Educação Pública (CIEPs).

A partir das políticas públicas elencadas no último quadro, foi elaborada uma leitura dos conceitos de marca e matriz espacializadas, através da concretização das mesmas. No quadro 5 elenquei as políticas e ações mais significativas da gestão pedetista e do brizolismo tanto na cidade quanto no estado do Rio de Janeiro.

\subsubsection{Programa Especial de Educação - marcas e matrizes}

O Programa Especial de Educação talvez seja a grande vitrine do brizolismo, seu projeto de maior expressão nacional, fez parte da Lei 705/1983. A principal marca espacial desse programa foram os Centros Integrados de Educação Pública (CIEPs) e a construção da Passarela do Samba ou Sambódromo, como também é conhecido o espaço onde desfilam as escolas de samba do grupo especial no carnaval carioca. Quanto aos CIEPs, a meta era construir 500, o que foi concretizado no segundo mandato de Brizola. Os dois elementos citados, tanto os CIEPs quanto a Passarela do Samba ${ }^{63}$, são as duas grandes marcas da política de educação. Como matriz dessa ação da gestão brizolista, temos, de acordo com os

\footnotetext{
${ }^{62}$ Aqui elenco cinco das dezenove metas, que considero como aquelas de maior impacto na política educacional: metas assistenciais ligadas a educação (material didático, uniforme e calçado); metas assistenciais não relacionadas a educação (melhoria da merenda e assistência médica e odontológica); metas de conservação das escolas; metas pedagógicas (aumento da carga horária de quatro para cinco horas, revisão de todo material didático, reforço adicional de horas de aula para melhoria do rendimento escolar, separação dos alunos do primeiro segmento dos alunos do segundo); novos projetos educacionais (Casas da Criança, com atendimento pré-escolar, criação dos CIEPs, criação dos Centros Culturais Comunitários, Educação Juvenil, com atendimento noturno para jovens de 14 a 20 anos); treinamento de professores (cursos de reciclagem de professores, curso de formação de professores, revitalização dos Institutos de Educação, reestruturação da carreira docente, do estatuto do professor e dos regulamentos das escolas). (EMERIQUE, 1997).

${ }^{63}$ Segundo Bomeny (1998, p. 98): A Passarela do Samba não foi uma construção com a finalidade de servir somente ao carnaval carioca, ou seja, para o desfile das escolas de samba do grupo especial. Esse espaço funcionava ao longo do ano como uma imensa escola e suas instalações abrigavam cerca de 160 salas de aula, 43 salas administrativas, Ensino Fundamental integral, Ensino Médio, formação de professores, centro de artes, ensino supletivo, quadras de esportes e bibliotecas.
} 
princípios da Carta de Lisboa, mencionado no seu plano de ação política, "salvar milhões de crianças abandonadas e famintas, bem como fazer com que os jovens alcancem os dezoito anos alfabetizados", para isso era necessário cumprir o terceiro compromisso do documento fundador do Novo Trabalhismo, "reverter as diretrizes da política econômica", que no entendimento da política brizolista deveria “priorizar a satisfação do povo" (CARTA DE LISBOA, 2006). A educação era percebida como um projeto civilizacional, pois através dela seria possível mudar os rumos da sociedade e do país: portanto um projeto emancipador. O projeto de educação criado durante o governo Brizola tinha uma perspectiva que a 'escola fosse além da escola', provendo crianças e adolescentes de serviços, como alimentação, tratamento médico e odontológico que permitiria a melhoria do aproveitamento escolar.

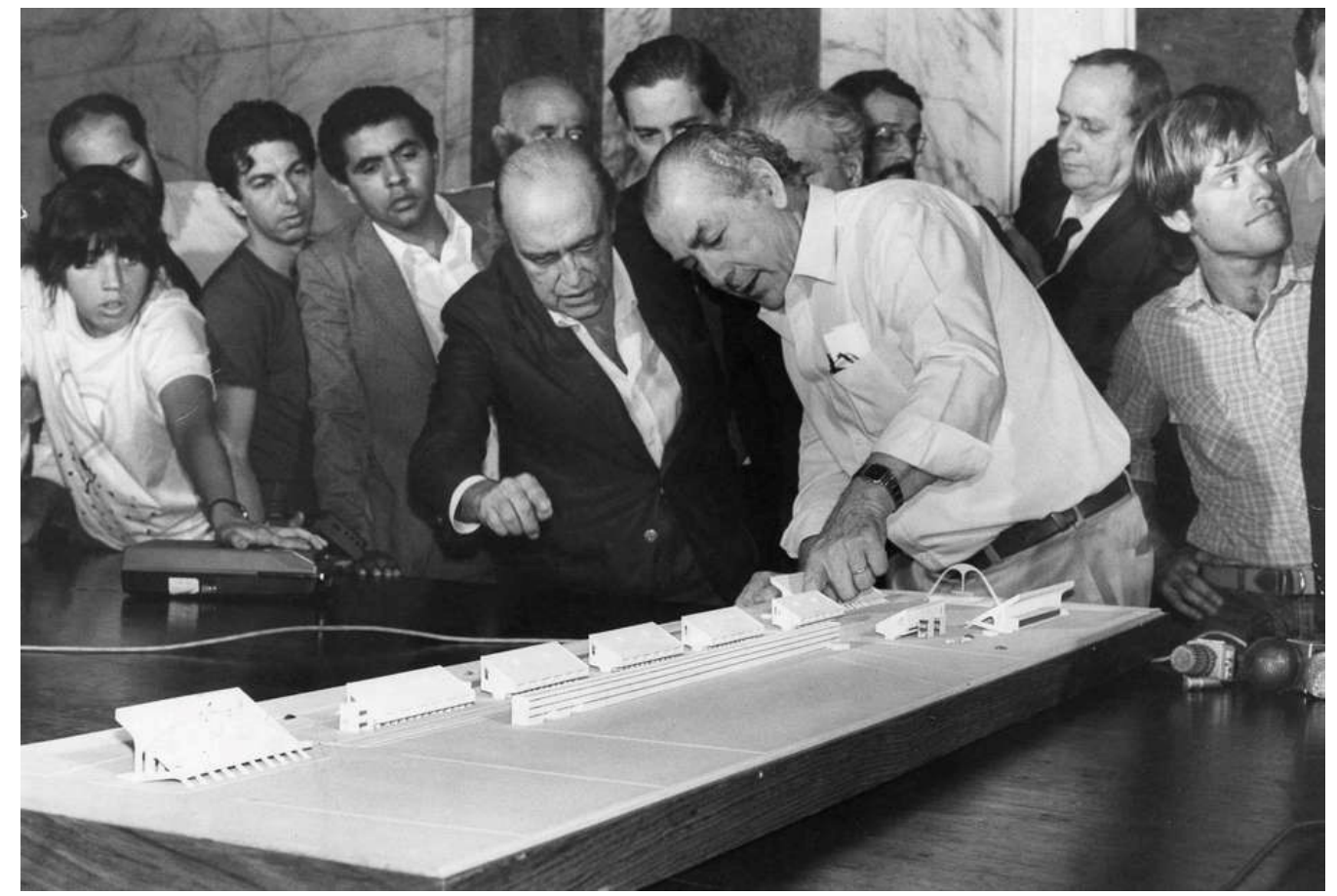

Imagem 13: Brizola e Niemeyer: projeto do sambódromo. Fonte: www.pft.org.br. Acessado em: 21/05/2021. 


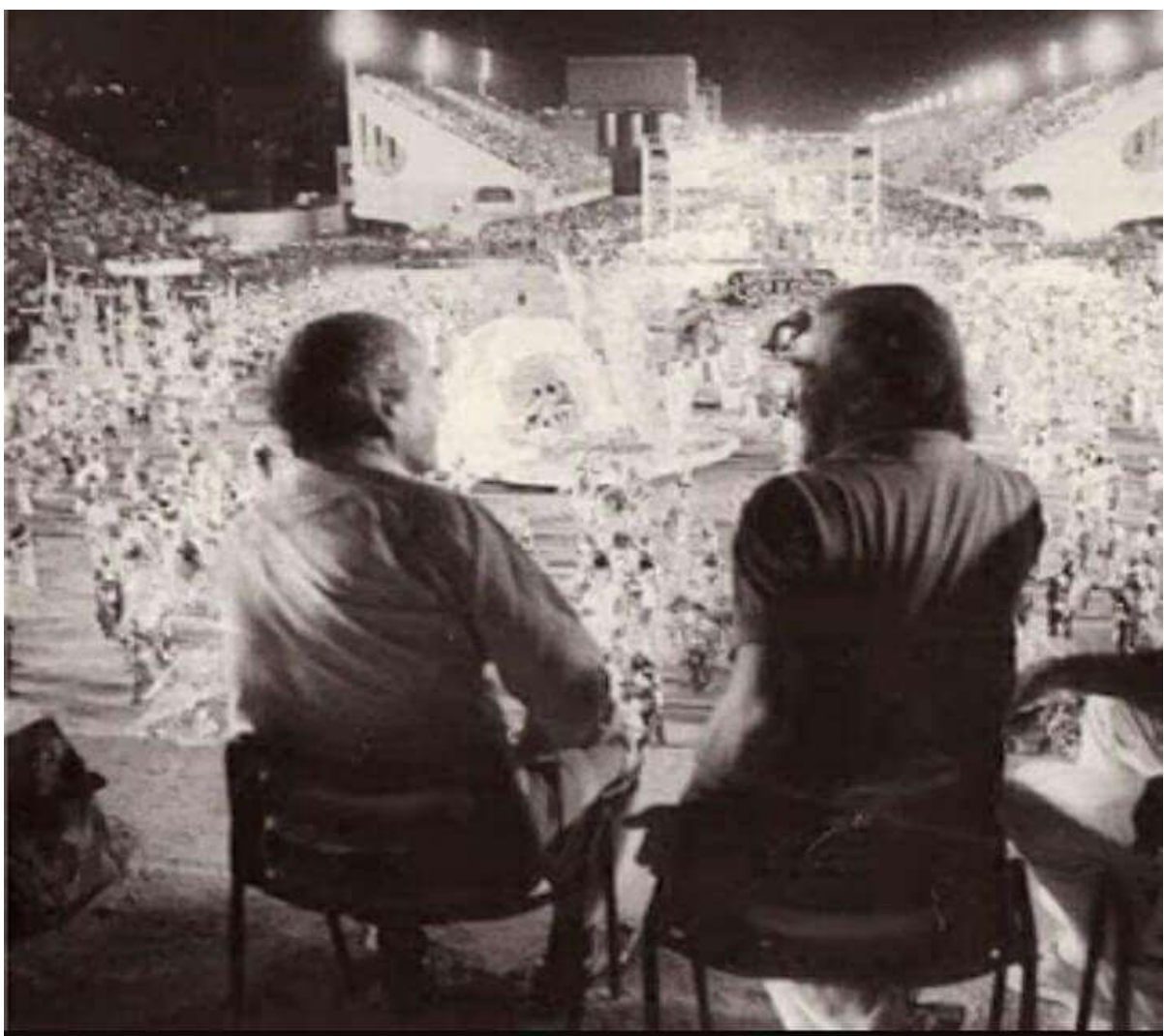

Imagem 14: Brizola e Darcy Ribeiro no primeiro desfile na passarela do Samba, 1984. Fonte: diáriodorio.com. Acessado em: 14/05/2021.

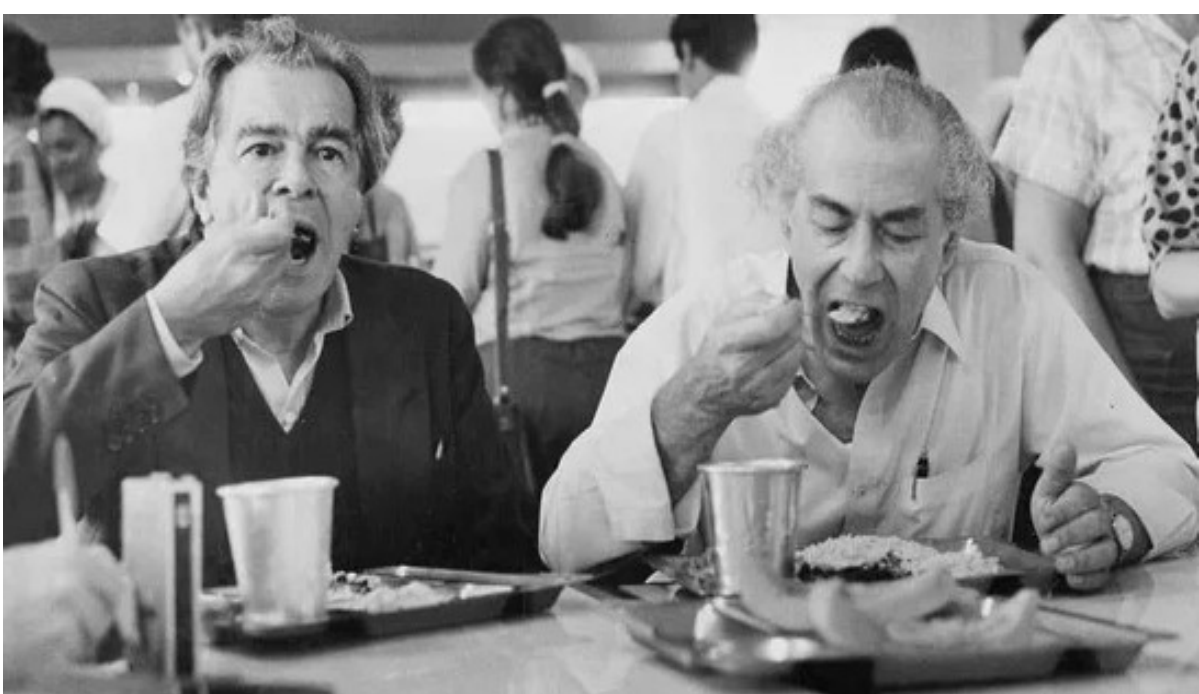

Imagem 15: Brizola e Darcy Ribeiro no CIEP em Campo Grande. Fonte: www.pdt.org.br. Acessado em: 14/052021 


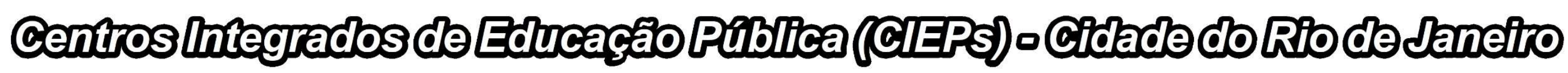

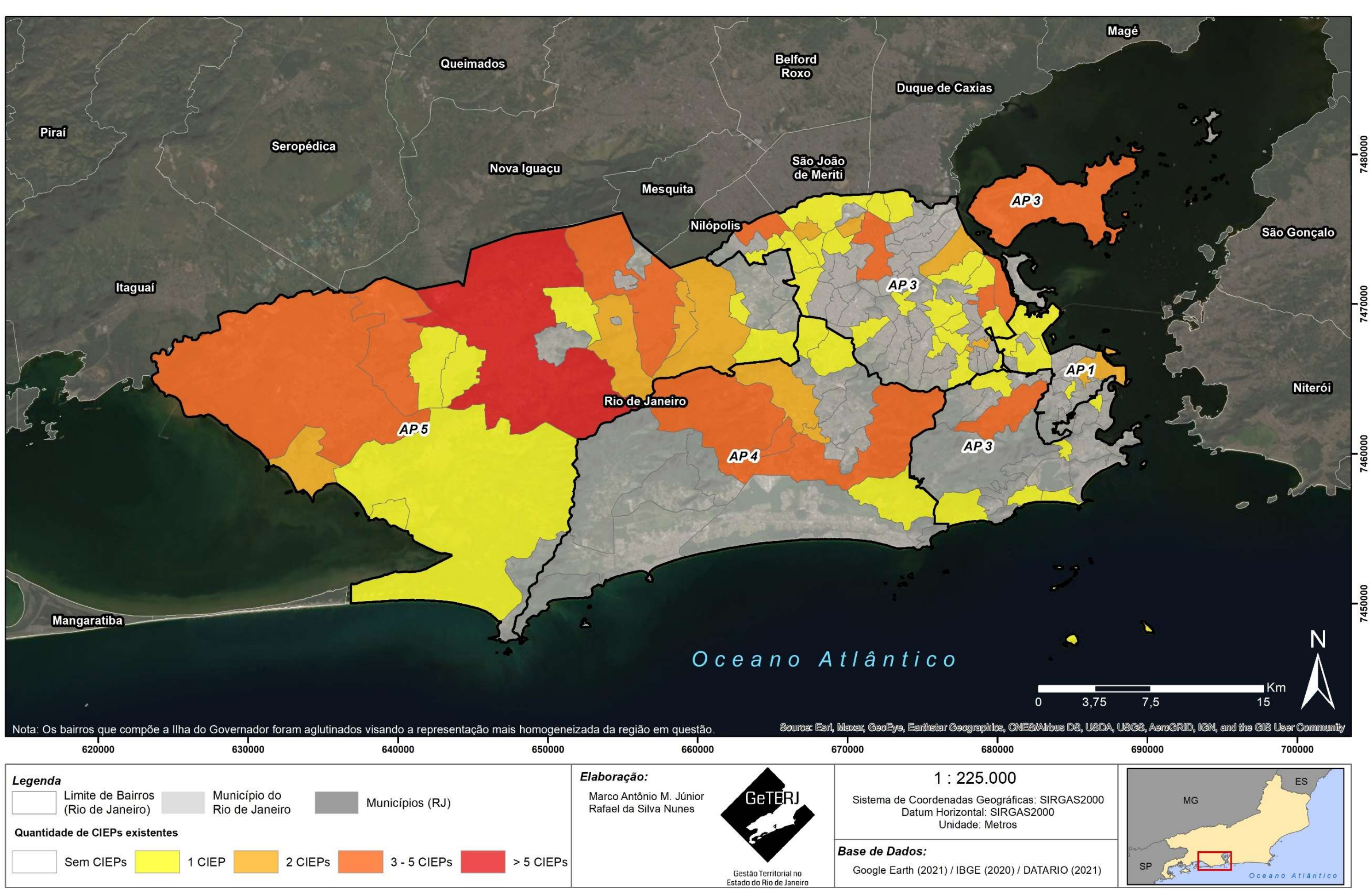

Mapa 4: Distribuição dos CIEPs no Rio de Janeiro 


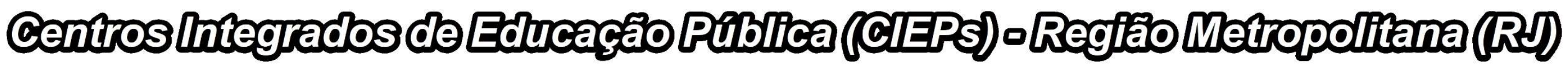

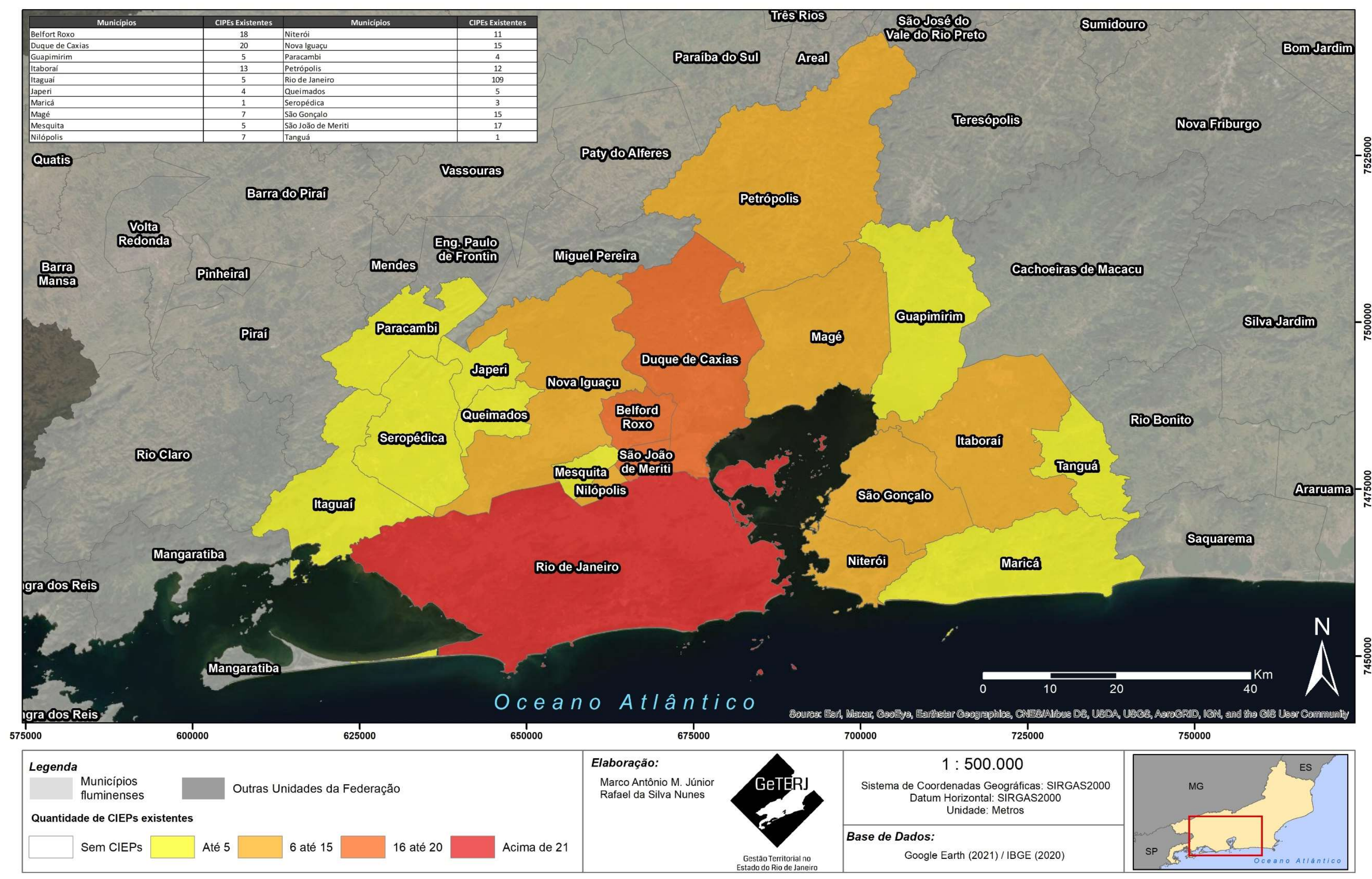


Analisando os mapas tanto da cidade do Rio de Janeiro quanto o que abrange a região metropolitana, algumas conclusões podem ser tiradas: a primeira - a maioria dos CIEPs estava em espaços marginalizados. No Rio de Janeiro, através da observação das APs, percebemos a maior concentração dessa política pública na zona oeste, que tem muitos bairros na AP5.

Quanto ao mapa dos CIEPs na Região Metropolitana, esse espaço encampa cerca de duzentas e setenta e sete escolas. Percebemos uma concentração espacial desses equipamentos, que pode ser interpretado a partir de dois ângulos. O primeiro, tem uma relação com o adensamento populacional e a concentração dos espaços de grande concentração miseropolizados (SOUZA, 1992), fazendo com que houvesse a intensificação de CIEPs para atender o grande contingente populacional.

O segundo ângulo de interpretação tem, de acordo com minha análise, uma matriz eleitoral. As eleições de 1982 foram vencidas por Brizola a partir da votação maciça de um eleitorado localizado na zona oeste e na Baixada Fluminense, portanto temos um importante elemento representativo dos objetivos do brizolismo: atender demandas reprimidas de áreas carentes. Nesse caso, uma resposta aos seus eleitores. Outro elemento está relacionado à institucionalização do brizolismo. A necessidade de angariar e cooptar lideranças locais e apoio popular, além de 'quebrar' a máquina política chaguista em um importante reduto de seu principal rival político na metrópole carioca, direcionando as políticas públicas pedetistas para a zona oeste. Creio que além da mudança de paradigma político, não baseado no clientelismo, que se caracterizou por atuações para atender demandas específicas, as políticas pedetistas tinham um alcance mais amplo, no que diz respeito a assistência aos segmentos mais vulneráveis da população desses espaços.

\subsubsection{Programa Cada família, um Lote: marcas e matrizes.}

O programa Pra Cada família, um Lote (Lei 705/1983) ${ }^{64}$ mudou a orientação das políticas públicas para as favelas do Rio de Janeiro, procurando

\footnotetext{
${ }^{64} \mathrm{O}$ programa Pra Cada Família, um Lote foi pioneiro na questão da política de gênero. Em consonância com a Carta de Lisboa que tinha como um de seus tópicos um programa de atenção às mulheres, ou seja, com políticas públicas que contemplassem as mulheres, esse programa priorizava as donas de casa como aquelas que seriam as proprietárias durante o processo de regularização fundiária implantada pelo programa.
} 
combater um problema crônico que já existia no espaço carioca: a falta de condições dignas de moradia e o déficit habitacional. Segundo Compans (2003), o programa tinha como objetivo distribuir um milhão de títulos de propriedade, no entanto entregaram 32.817 mil títulos em todo estado (p.46). Essa política pública, pelo seu teor que definiu novos parâmetros na questão da habitação do Rio de Janeiro, talvez tenha sido a que mais aproximou Brizola dos movimentos populares, particularmente das associações de moradores, capitaneadas pela FAMERJ (Federação das Associações de Moradores do Estado do Rio de Janeiro), sendo esta reconhecida como de utilidade pública pelo governo pedetista. A mudança consiste no fim das políticas remocionistas, tendo lugar a urbanização e a regularização dos terrenos e moradias em favelas.

Além da distribuição de títulos de propriedade o Programa Pra Cada Família, um Lote apresentava outras metas, que o tornavam mais amplo, pois havia também a preocupação com a urbanização de favelas, vista pelo governo como fundamental para melhoria da qualidade de vida das populações que habitam esses espaços. Outro aspecto significativo foi a contrapartida dos moradores com o pagamento simbólico de uma quantia que equivalia até 15\% do salário mínimo. No quadro seis sintetizo outras metas desenvolvidas pelo programa de habitação pedetista.

Quadro 6: Metas do Programa Pra Cada Família, um Lote

\begin{tabular}{|l|}
\multicolumn{1}{|c|}{ Metas do Programa Pra Cada família, um Lote } \\
\hline Regularização de 400 mil famílias \\
\hline Urbanização de 250 mil lotes na Região Metropolitana \\
\hline $\begin{array}{l}\text { Desenvolver projetos de } 200 \text { mil novos lotes que atendam o crescimento } \\
\text { vegetativo e as migrações }\end{array}$ \\
\hline Promover a melhoria dos conjuntos habitacionais \\
\hline
\end{tabular}

Fonte: criado pelo autor, 10/10/2021, a partir de Neves, 2007.

O programa não conseguiu alcançar as metas desejadas, pois além de ser muito arrojado quanto ao número de famílias e as diversas frentes que procurava atender, necessitava da formação de arquiteturas políticas, como a cooperação entre 
os entes federativos, esse, aliás, um dos grandes entraves, principalmente quanto a cessão de terrenos e desapropriações. Isso causou inúmeros embaraços legais, o que acabou dificultando a realização do programa. Sobre o tema, Compans (2003) mostra:

Se a propriedade fosse particular, optava-se pela desapropriação por interesse social. Se fosse do estado ou do município, transferência para o patrimônio do estado, e deste para Cehab. Se fosse da União solicitava-se ao órgão que detivesse a propriedade a regularização da situação dos moradores. (p.46)

A principal marca espacial desse programa, a regularização fundiária, permitiu o direito de propriedade para os moradores de favelas e um programa de urbanização desses espaços. Foi o primeiro programa voltado para urbanização de espaços favelizados. Mesmo não tendo alcançado a meta proposta, o programa foi importante, pois redirecionou as políticas habitacionais no Rio de Janeiro. Essa política pública, assim como todas as políticas desenvolvidas pela gestão pedetista, tem como matriz a Carta de Lisboa, a começar pelo seu terceiro compromisso e da ação política presente no mesmo documento que é dar "solução ao problema da marginalidade" (CARTA DE LISBOA, 2006). No mapa cinco, temos a distribuição espacial do Programa Pra Cada Família, um Lote, abrangendo, principalmente o município do Rio de Janeiro, que centralizou a maior parte do programa foi implementado. 


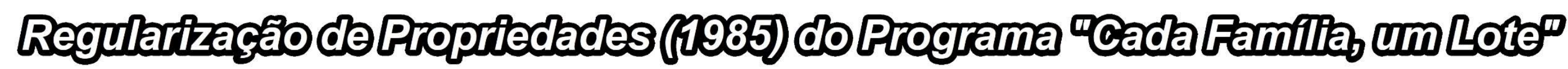

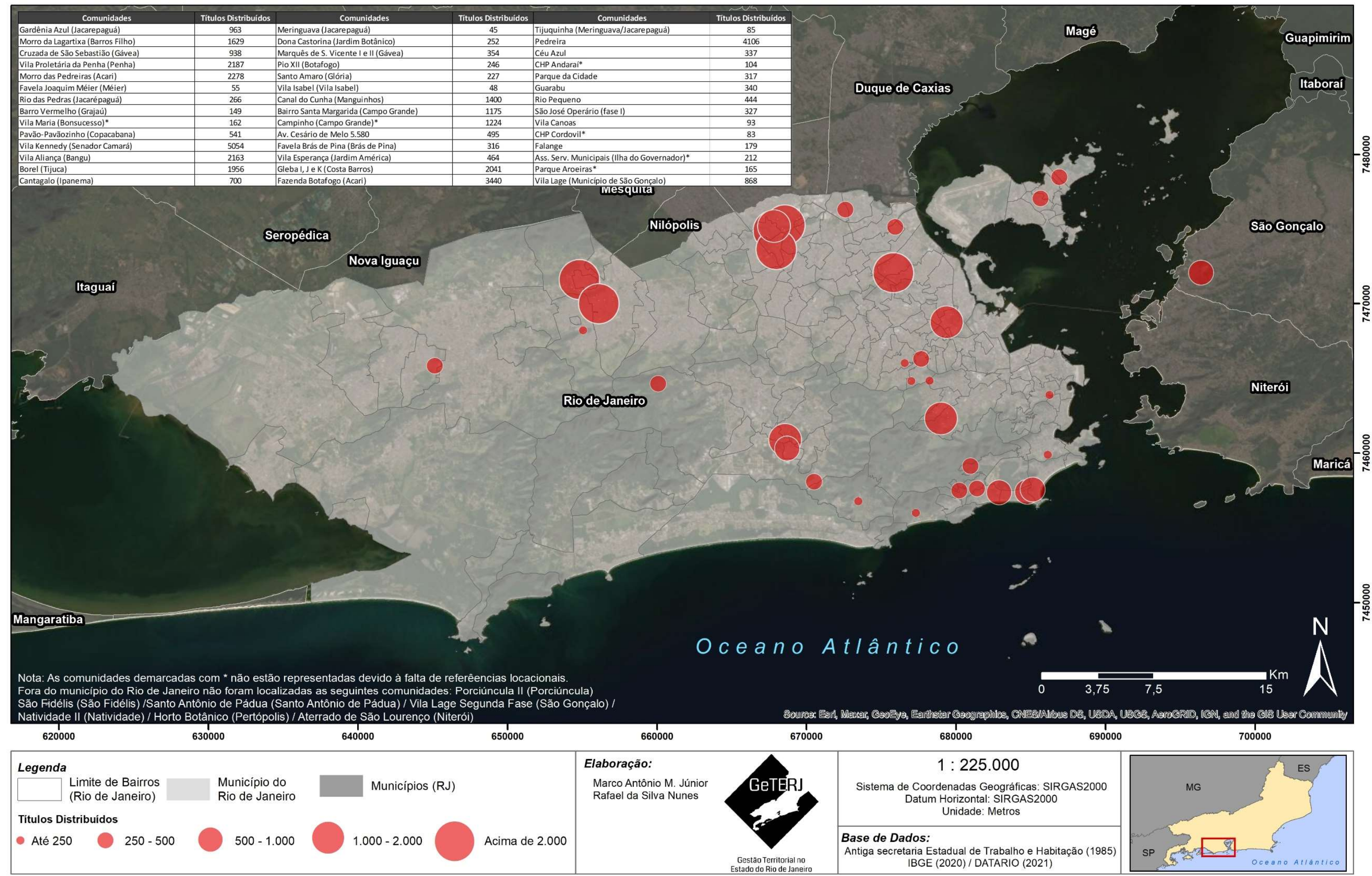


No mapa cinco é possível perceber que a maior parte do programa foi implementado nas zonas norte e oeste, áreas da cidade do Rio de Janeiro onde se localizam territórios marcados por maior vulnerabilidade, o que vai de encontro as políticas brizolistas, particularmente interessadas, de acordo com a Carta de Lisboa no atendimento a populações marginalizadas. Tenho um parecer semelhante com relação ao que foi mencionado sobre os CIEPs. Observo dois objetivos: atender a reivindicação de uma parcela numerosa da população carioca, o fim das remoções e, com isso, suprimindo uma das principais mazelas sociais do Rio de Janeiro. O outro é estabelecer uma relação de cunho eleitoral com os movimentos associativistas e, fazendo que o poder instituído consiga ao mesmo tempo, aumentar e manter sua representatividade eleitoral.

\subsubsection{PROFACE: marca e matriz}

O PROFACE foi um programa do governo do estado que tinha como uma de suas funções básicas dotar de infraestrutura espaços como favelas e áreas periferizadas. Também fazia parte do programa de urbanização de espaços favelizados. Atuava em conjunto com o Pra Cada Família, um Lote. Para o governo do estado era um projeto de grande relevância, pois resolveria um dos graves problemas que reproduzia vulnerabilidade nessas áreas, ou seja, água potável e esgoto. O programa foi promovido pela Companhia Estadual de Água e Esgoto (CEDAE), que segundo Neves (2007) a empresa "definiu um programa de ação integrada e prioritária, prestou atendimento em favelas, incorporou a participação da comunidade em todas as suas fases" (p.91). A marca espacial foi à criação de redes de esgoto e água encanada nesses espaços e a inclusão da favela na vida urbana regular. Quanto à matriz dessa política, segue as diretrizes da Carta de Lisboa, pois procurou dignificar espaços marginalizados, através de melhorias em infraestrutura básica, que objetivava uma política inclusiva, de acordo com as ações políticas da Carta de Lisboa. 


\subsubsection{Programa Uma Luz na escuridão ${ }^{65}$ : marca e matriz}

Esse programa foi desenvolvido pela Light com o objetivo de levar luz elétrica para as casas, principalmente em favelas, conjuntos habitacionais e em bairros que têm carência dessa infraestrutura. O Programa é vinculado ao Pra Cada Família, um Lote, já que a sua meta era dotar espaços favelizados e periféricos de infraestrutura básica com o objetivo de melhorar a qualidade de vida de suas populações, portanto a espacialização do mesmo está de acordo com o projeto de urbanização de favelas proposto pelo governo Brizola. A marca principal foi trazer energia elétrica para as favelas visando melhorar a qualidade de vida e as condições de segurança pública, vigentes nesses espaços. Como matriz está no mesmo contexto dos dois programas anteriores, segundo os compromissos e ações estabelecidas pela Carta de Lisboa.

\subsubsection{Projeto Mutirão Comunitário ${ }^{66}:$ marcas e matriz}

O Projeto Mutirão foi um dos mais importantes da gestão pedetista, devido o envolvimento de diferentes níveis de governo tanto estadual quanto municipal. Esse projeto, promovido pela Secretaria Municipal de Desenvolvimento Social tinha como objetivo a melhoria da qualidade de vida nas favelas, através de benfeitorias na infraestrutura. Para isso, utilizava mão de obra local e remunerada. Um aspecto a ser ressaltado, é que sua realização foi de forma integrada com a cooperação de diversos órgãos e esferas governamentais (secretarias de estado, do município, regiões administrativas), além da participação da Federação de Favelas do Estado do Rio de Janeiro (FAFERJ) e das associações de moradores. Sob o ponto de vista da execução, foi um programa caracterizado pela inclusão, pois contou com

\footnotetext{
${ }^{65}$ Programas como PROFACE e Uma luz na escuridão visavam dar infraestrutura para as favelas, mesmo com a irregularidade na ocupação do solo nesses espaços. Para os moradores desses espaços, para as associações de moradores e a FAFERJ eram considerados programas importantes para melhoria da qualidade de vida. No entanto, para alguns segmentos da sociedade e para adversários políticos, não passavam de programas demagógicos, clientelistas e populistas, que visava somente a cooptação e a formação de bases eleitorais.

${ }^{66} \mathrm{O}$ Projeto Mutirão Comunitário foi em princípio uma política municipal, que tem seu início no governo Saturnino Braga, quando este esteve à frente da prefeitura do Rio de Janeiro. Não vejo problema em colocá-la como um programa que está relacionado ao governo Brizola, já que atendia aos mesmos princípios e deliberações do que se pretendia no governo do estado.
} 
a participação das populações locais em todas as suas fases, desde a concepção do projeto até a realização das obras (NEVES, 2007).

O projeto abrangeu cerca de 60 favelas. Segundo Barboza (2013) houve um desdobramento do programa voltado para a contenção de encostas, a recuperação e regularização das nascentes e mananciais, a limitação da expansão das comunidades em áreas de risco e a recomposição paisagística (p. 72-3). É relevante salientar que o arranjo político e institucional que possibilitou a execução do programa foi a partir da sinergia que envolveu as associações, os moradores e os governos estaduais e municipais, portanto uma política pública integrada e com participação popular. A marca espacial predominante foi à infraestrutura (saneamento e arruamento) e a construção de habitações para os moradores desses espaços. Como matriz, segue as diretrizes da Carta de Lisboa, com relação aos projetos de infraestrutura, isto é, a melhoria da qualidade de vida e inclusão de espaços marginalizados a cidade.

\subsubsection{Fim da "Política do Pé na Porta"}

A política de segurança pública do governo de Leonel Brizola foi bastante polêmica, talvez a mais, dentre todas as ações realizadas por essa gestão. Foi marcada por uma reorientação na política de segurança executada no estado do Rio de Janeiro. A denominação informal dada a essa nova forma de lidar com a segurança pública é bem sugestiva, já que procurou desvincular o governo pedetista das práticas comuns utilizadas no período da ditadura militar. Como uma das medidas principais dessa política, tivemos a extinção da Secretária de Segurança Pública e a criação do Conselho de Justiça, Segurança Pública e Direitos Humanos, que reuniu representantes da sociedade civil e, não somente autoridades ligadas à segurança pública.

A política de segurança pedetista buscou erradicar a ação reativa com relação à atuação das polícias, observando que segurança pública não é somente ação policial ${ }^{67}$. Houve a pretensão de reformar as polícias, principalmente a militar

\footnotetext{
${ }^{67}$ É importante essa afirmação, porque a segurança pública vai além da atuação das polícias civil e militar. Algumas questões como iluminação pública e, até mesmo poda de árvores também fazem parte de uma política desse tipo. No entanto, levando em consideração como atuavam as polícias no Rio de Janeiro durante a ditadura militar, havia a necessidade de uma ação policial que fosse preventiva. Estava dentro do que o grupo que pensava a segurança pública do estado nesse momento chamava de "criminologia crítica", em que as situações que implicavam em crime não eram somente
} 
com funcionamento mais humanitário, levando em conta os anseios das comunidades que habitavam as favelas e deixando de lado às ações arbitrárias que tinha como "modus operandi" a violência como forma de atuação nesses espaços. É importante observar, que a polícia como poder instituído, era vista com muita apreensão por ser um dos instrumentos utilizados para efetuar a remoção das populações de favelas quando essa era a tônica política. As operações policiais eram truculentas quando havia resistência por parte da população que não queria ser removida.

\section{Como afirma Silva 2015:}

O governo Leonel Brizola dedicou atenção especial à questão dos direitos humanos e à violência policial, principalmente às ações discricionárias e racistas nas favelas. Dedicava igual respeito aos direitos de inviolabilidade privada, procurando manifestar em iniciativas práticas a marca popular que assumira em campanha. (p.194)

Teremos, portanto, outro paradigma na política de segurança pública da cidade e do estado do Rio de Janeiro, com a mudança na configuração de atuação do aparato policial, tendo como consequência uma tentativa de humanização dos aparelhos de segurança e de conexão com as comunidades.

Um importante interlocutor dessa política de segurança foi o Coronel Carlos Magno Nazareth Cerqueira, que estava à frente da Polícia Militar do Estado do Rio de Janeiro (PMERJ), sendo um dos principais artífices da promoção de mudanças nessa corporação, procurando retirar a lógica militarista relacionada à defesa social (CERQUEIRA, 1996). O objetivo foi reavaliar e mudar a forma de atuação da polícia enquanto agente de segurança pública, ou melhor, transformar da instituição.

Como marca, temos a implantação de um Conselho de Segurança Pública e Direitos Humanos, um funcionamento mais preventivo e a aproximação com as comunidades locais. No que diz respeito à matriz da política de segurança pública do governo Brizola, temos na Carta de Lisboa o seu fundamento, pois no horizonte

um problema de polícia, mas também comunitário. Nesse sentindo vai ser buscada uma maior cooperação com os moradores das favelas na afirmação de políticas públicas que fossem mais eficientes e menos agressiva sob o ponto de vista de sua ação ostensiva. Os policiais deveriam ser vistos como um servidor público e não como agentes de um aparelho repressivo. 
do documento há a luta em favor da justiça e, para isso deve haver o respeito aos direitos humanos.

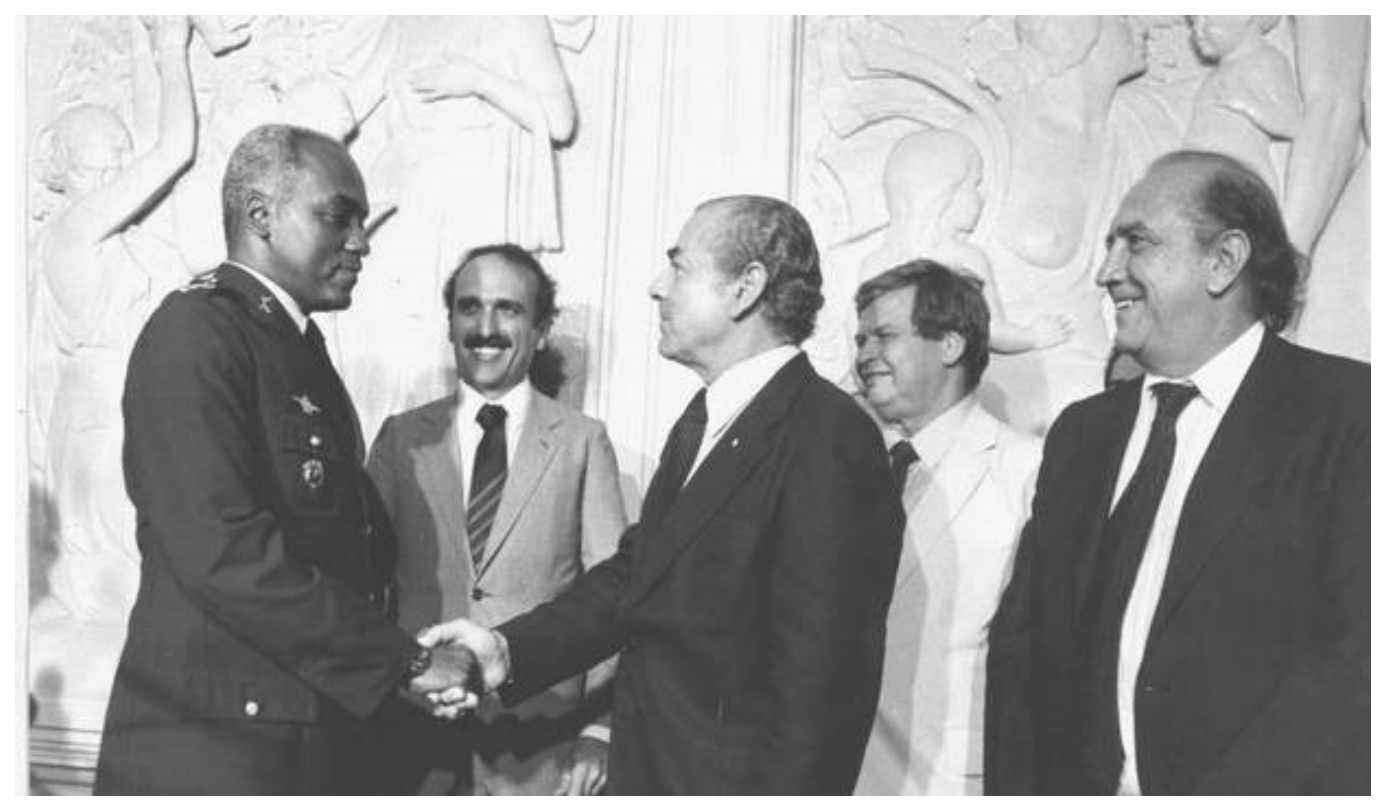

Imagem 16: Brizola e Carlos Nazareth Cerqueira: responsável pela política de segurança do governo pedetista.

Fonte:disparada.com.br. Acessado em: 20/09/2021.

Uma das conclusões que chego com relação às políticas públicas brizolistas é que procuraram atender uma parcela significativa da população carioca e fluminense, principalmente as camadas sociais mais vulneráveis. É possível perceber a conexão entre os propósitos das políticas de Brizola e a intencionalidade de seus programas ao que está referendado na Carta de Lisboa tanto em seus compromissos prioritários como nas ações políticas e nas declarações presentes no mesmo. Nota-se a sinergia entre as políticas realizadas, porque é perceptível a relação entre as mesmas. Todas as políticas apresentadas, sem exceção, têm como objetivo ou meta principal, melhorar a qualidade de vida dos segmentos mais marginalizados da população. Portanto, antes do regimento partidário o documento que deve ser seguido foi o redigido em junho de 1979.

\subsection{O Brizolismo como instrumento de análise socioespacial: símbolos e representações}

Como insistentemente discutido, o brizolismo, suas políticas públicas e ações, podem ser considerados, como importante manifestação política, que 
norteou uma série de gestões públicas que se faz presente no Rio de Janeiro até os dias atuais.

Aqui pretendo enfatizar as representações acerca das políticas públicas, bem como sua finalidade na definição de uma identidade brizolista e do brizolismo no espaço carioca e fluminense.

Nesta seção analiso, sob uma perspectiva espacial, as representações deixadas pela gestão pedetista no estado do Rio de Janeiro. Para estabelecer essa análise procuro me apoiar em autores como Jodelet (2001), Jovchelovitvh (1995) e Moscovici (2009).

Sob o ponto de vista socioespacial, o brizolismo está vinculado ao estado do Rio de Janeiro e, como já enfatizado, mais especificamente a sua capital, sendo espacializado através de suas próprias ações políticas que geraram marcas concretizadas no espaço, que pode ser exemplificada por uma política que se tornou uma das principais imagens do brizolismo, com repercussão nacional, os Centros Integrados de Educação Pública (CIEPs) e pela Passarela do Samba, além de outras políticas abordadas na seção anterior.

De acordo com as observações sobre as representações do brizolismo, vários aspectos podem ser assumidos acerca do governo Brizola, concebendo interpretações positivas e negativas, acerca das políticas adotadas no Rio de Janeiro. Os mesmos fatores que alimentam de forma positiva os brizolistas foram aqueles que promoveram uma retórica repulsiva com relação ao seu governo, estabelecido a partir de 1983.

Pretendemos evidenciar as diversas formas de representações sobre o governo pedetista no Rio de Janeiro. Todas carregadas de fatores emocionais, pois a própria imagem de Brizola criou marcas sobre sua forma de fazer política. Assim os questionamentos daqueles que são detratores seguem uma lógica parecida com a dos defensores dos projetos e programas realizados, por isso, o discurso brizolista foi sempre seguido pela sua antítese, o antibrizolista.

O forte vínculo de Brizola com o Rio de Janeiro foi reforçado por sua atuação política enquanto governador, por duas vezes, levando a uma identidade com o carioca, como afirma Sento-Sé, 1999: 
O grau de identificação da figura de Brizola com representações sociais fortemente significativas do carioca foi de tal ordem que ele, Brizola, acabou por ser uma das principais referências políticas do Rio de Janeiro, desde seu retorno do exílio. Ainda hoje, afastado do poder e após algumas derrotas acachapantes, seu nome aparece evocado, para o bem ou para o mal, quando os debates políticos se aguçam e os processos eleitorais são desencadeados. (p.44)

No contexto das representações sociais, entende-se que para representar algo é necessário dotá-lo de significados e, para isto símbolos e signos devem ser utilizados que podem conferir valores individuais e coletivos. As representações buscam criar similitudes através de classificações, com o objetivo de tornar fenômenos sociais não familiares em familiares como observa Leme (2004): Para ela:

\begin{abstract}
A função das representações é tornar o familiar e o não familiar numa dinâmica em que os objetos e os eventos são reconhecidos, compreendidos com base em encontros anteriores, em modelos. No caso, a memória predomina sobre a lógica, o passado sobre o presente, a resposta sobre o estímulo. $\mathrm{O}$ ato de representação transfere o que é estranho, perturbador do universo exterior para o interior, coloca-o em uma categoria e contexto conhecidos. (p.48)
\end{abstract}

Jodelet (2001) argumenta que as representações, enquanto construções sociais partilhadas, contribuem para construção de normas e situações de pertencimento, através das experiências, práticas e modelos que engendram os comportamentos transmitidos pela mídia que, ao intervirem na elaboração das mesmas, acabam sendo incutidas nas nossas vivências.

Outros autores também contribuem na discussão das representações e do universo simbólico acerca delas. A partir da contribuição teórica evidenciada pelos mesmos será possível observar diferentes representações acerca de Brizola e do brizolismo. Essas representações foram manifestadas em construções coletivas que dotam de significados e sentimentos enobrecedores dessa liderança, que vamos chamar de brizolismo.

Através dessas diferentes construções e representações tanto com relação à liderança de Brizola quanto às políticas públicas adotadas pelo brizolismo no Rio de Janeiro, temos na metrópole carioca o seu principal espaço de representação. 
Nele as marcas fundamentais do brizolismo foram colocadas em prática, com elementos concretos no espaço, como observado ao longo do capítulo.

Jovchelovitch (1995) fez uma importante reflexão sobre o chamado espaço potencial relacionado diretamente ao universo simbólico, observando que os símbolos são capazes de evocar a presença apesar da ausência (p.74). Nesse sentido, os símbolos criam o objeto representado, construindo uma nova realidade sobre a preexistente, e provocam a fusão entre sujeito e objeto, porque eles são expressão de uma relação intrínseca.

A afirmação da autora acima merece algumas considerações e aproximações importantes sobre o que aconteceu no Rio de Janeiro após as eleições de 1982 e a entrada de Brizola e seu grupo no poder tanto carioca quanto fluminense.

A primeira consideração se refere à reflexão sobre um espaço potencial. Nesse caso, é possível afirmar que o Rio de Janeiro, principalmente sua capital, apresenta as características desse tipo de espaço, já que uma das representações conferidas a esse território é ter sido o berço do brizolismo, centro de seu projeto difusor, constituindo nova capitalidade e, a formação de um capital simbólico que permite evocar uma herança do brizolismo, através de elementos concretos no espaço.

A outra reflexão indica que esse potencial também foi o berço do chamado antibrizolismo, onde suas políticas públicas foram alvo de contestações e defecções por parte de seus opositores. Para estes a política brizolista não foi popular, mas populista. A população não foi partícipe do processo de confecção de políticas públicas, mas cooptadas para seu principal propósito eleitoral, a presidência da República.

O relevante na análise é que não importa que tipo de representação seja referenciado a Brizola e ao brizolismo, mas é inegável a marca que exerceu e exerce na política carioca e que as formas simbólicas espacializadas por suas ações permitiram a construção de uma "iconografia política da paisagem" (LEIB, 2002) tanto no espaço carioca quanto no espaço fluminense. 


\section{A Cinelândia como marca e matriz, a Brizolândia: do espaço público ao espaço da política brizolista}

No início da década de 1980, com o retorno de Leonel Brizola à cena política brasileira, foi estruturado um movimento identitário de adeptos do "caudilho" em um dos espaços mais icônicos da República brasileira: a Cinelândia. Marco de grandes movimentos políticos nacionais, a Praça Floriano Peixoto tem entre outros símbolos da política nacional, o busto do ex-presidente Getúlio Vargas (imagem 17), o introdutor do trabalhismo na política brasileira. Em torno desse busto, os adeptos do brizolismo passaram a se reunir e a deflagrar discussões e apoios determinantes para alicerçar as políticas do Novo Trabalhismo, trazidas pelo PDT através de Leonel Brizola.

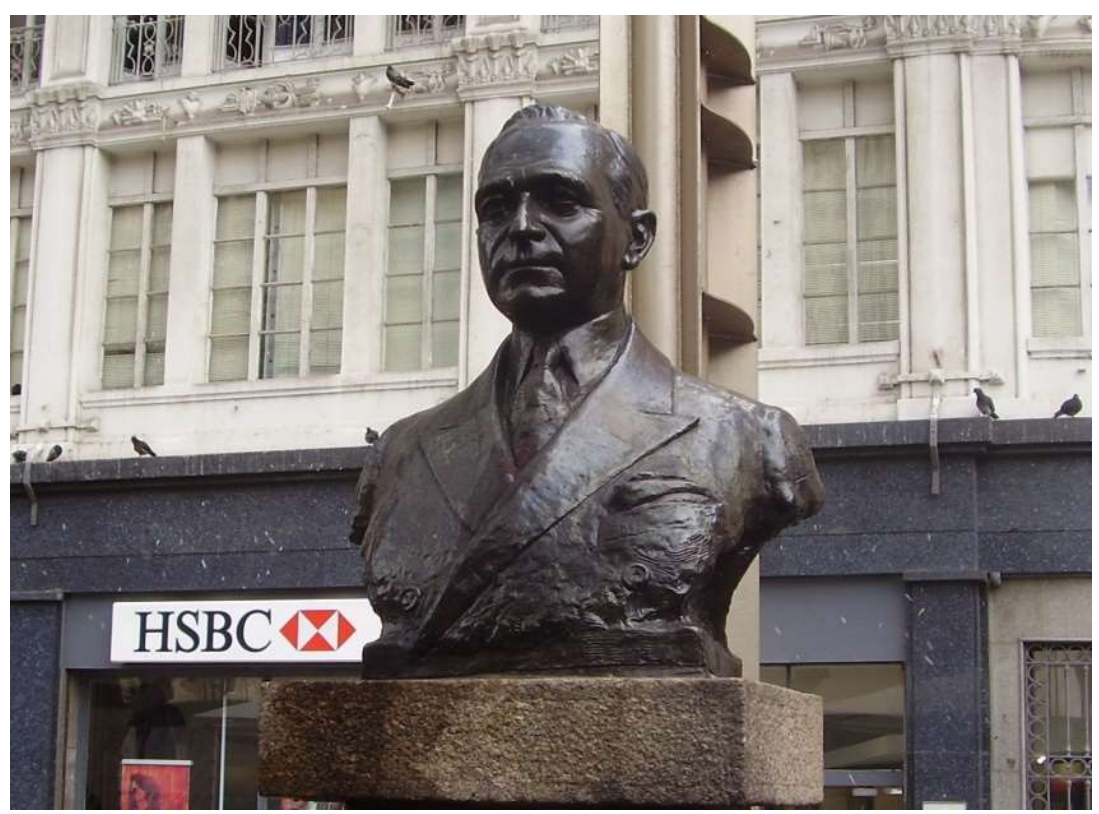

Imagem 17: Busto de Getúlio Vargas, primeiro introdutor do trabalhismo na política brasileira. Fonte: http://ashistoriasdosmonumentosdorio.blogspot.com. Acessado em: 31/07/2021.

A ocupação desse espaço pelos apoiadores do trabalhismo histórico brasileiro, cujo representante instituinte passava a ser Leonel Brizola, criou naquela praça, localizada no centro histórico do Rio de Janeiro, uma territorialidade chamada Brizolândia, acrônimo formado por Brizola e Cinelândia.

Em uma simbiose de ideias, espaço e simbolismo, a Brizolândia proporcionou um dos movimentos populares mais importantes da cidade do Rio de Janeiro à época, que ajudou a estabelecer uma identidade bastante consolidada entre o líder trabalhista, retornado do exílio, e a metrópole carioca. 
Construída na gestão do então prefeito Francisco Pereira Passos (19021906), nomeado interventor na antiga capital pelo presidente paulista, Rodrigues Alves, a Praça Floriano Peixoto é fruto da grande reforma urbana sofrida pela cidade para tornar-se 'o símbolo da modernidade brasileira'. As reformas urbanas da primeira metade do século XX talvez sejam o grande marco pelas quais a "Cidade Maravilhosa" vem passando, mas ainda conservando aspectos e elementos espacialmente distribuídos nessa área do Centro da Cidade ${ }^{68}$. Por isso, é um grande referencial histórico e identitário que faz parte da memória urbana e um dos símbolos da capitalidade do Rio de Janeiro.

Localizada no final da Avenida Rio Branco, antiga Avenida Central (primeira rua efetivamente linear e ampla da cidade inaugurada em 1906 e símbolo da conexão 'área de gestão - área portuária' do Rio de Janeiro), a Cinelândia tem um conjunto arquitetônico representativo da 'Belle Époque' carioca do período, que substituía as formas da cidade imperial e também colonial.

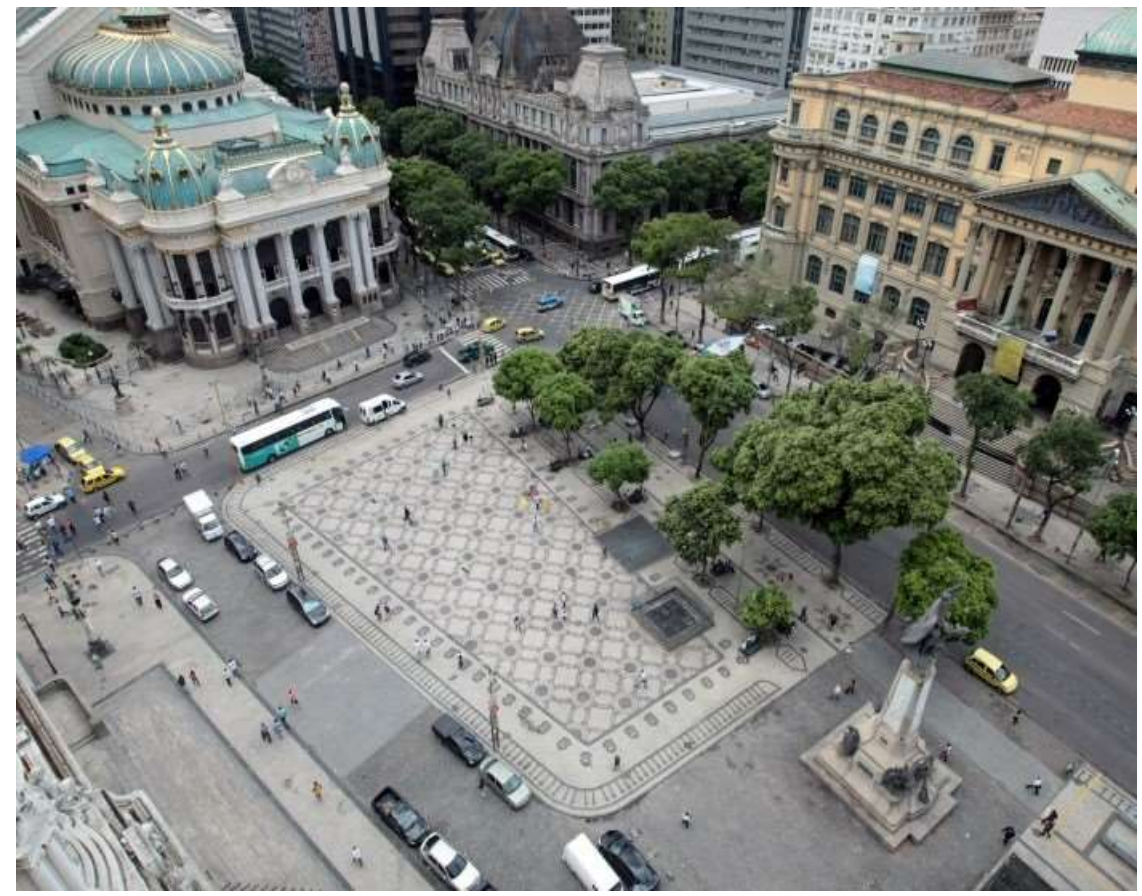

Imagem 18: Praça Floriano Peixoto: popularmente conhecida como Cinelândia espaço onde foi criado o movimento popular da Brizolândia.

Fonte: www.polyedros.com.br. Acessado em: 27/07/2021.

\footnotetext{
${ }^{68}$ Podem ser destacados como símbolos culturais e políticos expressivos presentes atualmente nesse espaço da cidade carioca o Palácio Monroe, a Escola Nacional de Belas Artes, o Teatro Municipal, o Supremo Tribunal Federal, atualmente Centro Cultural Justiça Federal e o Palácio Pedro Ernesto, atual Câmara dos Vereadores da Cidade do Rio de Janeiro, além de bares como o famoso Amarelinho.
} 
Além de uma importante e imponente demarcação da modernização e ressignificação do centro da cidade e da própria metrópole, a Cinelândia também se tornou palco de relevantes manifestações, ao longo de todo período republicano, bem como um epicentro de várias campanhas políticas em momentos memoráveis da história do Brasil no século XX.

É nesse contexto que analisamos a Praça Floriano Peixoto como Brizolândia, denominação dada pelo movimento popular de apoio ao governador Leonel Brizola na Cinelândia. Observaremos como um espaço público foi apropriado por um grupo de apoiadores e de eleitores que o utilizaram para fazer a campanha política para o governo do estado de 1982.

\subsection{A Brizolândia: lugar e ação popular do brizolismo}

\subsubsection{O surgimento da Brizolândia}

O Movimento Popular da Brizolândia surgiu no dia 2 de abril de 1982, período em que o Rio de Janeiro e todo território brasileiro se preparava para as eleições mais importantes desde o golpe militar de 1964.

O movimento durou doze anos, até 1994. Durante o período em que esteve ativo, foi na Praça Marechal Floriano, que os brizolistas territorializaram o espaço e formaram um movimento político espontâneo em relação a uma liderança política, com um propósito único, eleger Leonel Brizola para o governo do estado do Rio de Janeiro.

A escolha pela Cinelândia, de acordo com sua principal liderança, chamada 'Pernambuco', se devia ao fato de que “nesse espaço muitos movimentos políticos foram registrados" (SOUZA, 1993). Na verdade, um dos valores simbólicos conferidos a esse espaço do centro histórico do Rio de Janeiro é sua representação enquanto palco de inúmeras manifestações desde os períodos mais rígidos da ditadura, como também de comícios e atos de apoio a candidatos, além de protestos reivindicatórios.

A apropriação da Cinelândia pelos brizolistas tornou-a um importante recurso eleitoral para Brizola e o pedetismo em sua campanha política. A escolha 
da praça tinha relação com sua localização, com o grande número de transeuntes e por ser um espaço iconográfico da cidade. Ademais, as representações acerca da praça e sua centralidade foram valorizadas enquanto espaço para que o movimento fosse instalado.

De acordo com Cardoso (1993):

A Brizolândia existiu como um ator político, com forte identidade e visibilidade pública, sediada na Cinelândia a partir de abril de 1982, organizada por um grupo social heterogêneo de profissionais liberais, mobilizando trabalhadores de média e baixa renda, com ou sem carteira assinada, desempregados, aposentados, funcionários públicos e estudantes. (p.11)

Formado por segmentos populacionais diversos da estrutura social carioca, o movimento da Brizolândia objetivava tornar a sua ação uma prática cotidiana de pressão política no território, a partir de um espaço público com grande visibilidade e valor simbólico na cidade. Nesse sentido, as discussões entre os seus membros poderiam ser acessadas por qualquer transeunte na praça, ampliando o leque de informações sobre Brizola, suas ideias, agenda política e objetivos partidários através do PDT.

Tal confluência deu à Brizolândia um sentido de espaço de significados para a pessoalidade, personalidade e compromissos do brizolismo, a partir de Brizola, o que ampliava o leque de apoios ao então candidato e futuro governador. Muitos participantes desse movimento e circulantes nesse espaço no cotidiano da cidade evitavam alardear a ideia de 'culto à personalidade' do líder pedetista, mas sim a um constante e forte apoio à luta política presente na sua agenda governamental. Tal apoio se espraiava no desejo de ruptura com o modelo político e econômico vigentes, o que insuflava a ideia de uma 'verdadeira' democratização do país.

Nesse sentido, Sento-Sé (1999) nos ilustra a visão acerca do movimento político da Brizolândia e de seus integrantes. Segundo o autor,

O brizolismo, entendido como adesão à liderança de Brizola, é aqui tratado como um caso típico, em que a correlação entre imaginário social e o líder foi operada ao longo do tempo. Quando os militantes da Brizolândia, com seu alegado primarismo político e intolerância, repetem ciosamente que não cultuam a figura de Brizola, mas as ideias com ele partilhadas e o que ele representa no cenário político brasileiro, seus projetos 
e utopias, estão a seu modo, revelando algo que não pode passar despercebido aos olhos do intérprete interessado. Não se trata, nesse caso, de uma postura apenas defensiva contra as acusações de personalismo que suposta e provavelmente teriam presidido o movimento. (p.25-26)

É interessante notar que o autor utiliza o conceito de primarismo político para se referir ao movimento que foi criado na Praça Floriano Peixoto, pois assim entenderíamos o vínculo dos participantes, ou da maior parte deles, através da passionalidade que, por sua vez, é marcada por uma irracionalidade que se expressaria em um espaço público, muitas vezes atuando de forma violenta contra opositores de Brizola, durante o processo eleitoral.

Outro aspecto quanto ao surgimento do movimento político é que atuava de forma tangenciada ao Partido Democrático Trabalhista (PDT), ou seja, não fazia parte da estrutura partidária. Esse fator é importante, porque não era uma segmentação do partido e, com isso, não havia ingerência da legenda no movimento. No entanto, seus integrantes tinham total liberdade para fazer campanhas em prol de candidatos pedetistas. Portanto, havia independência de atuação e uma relação de aproximação e distensão com a Sete de Setembro ${ }^{69}$.

Sendo um movimento político marcado pela espontaneidade, bastante heterogêneo quanto a seus integrantes e não orgânico se configurava mais como uma forma de ativismo político que atuava de mais livremente, pois não tinha intenção de política de forma cartorializada ${ }^{70}$, ou seja, seguindo normas e estatutos partidários. No entanto, a despeito de não ser parte do partido, a atuação do movimento tinha relação estreita com o que acontecia no PDT, pois exercia o papel de cabo eleitoral dos candidatos pedetistas.

O brizolismo foi um fenômeno político muito além do pedetismo e a questão da adesão a Brizola pelo seu carisma e por sua agenda política explica parte dessa dissociação. Além disso, muitos episódios envolvendo outros políticos que

\footnotetext{
${ }^{69} \mathrm{Na}$ Rua Sete de Setembro está sediado o principal diretório do Partido Democrático Trabalhista na cidade do Rio de Janeiro.

${ }^{70}$ Quando há referência sobre política cartorializada, os integrantes do movimento se remetem a uma forma de fazer política ligada a uma estrutura hierárquica que existe nos partidos, além disso, para alguns integrantes da Brizolândia, a forma como os partidos são estruturados ingessam a forma de atuação política, por isso a busca de uma atuação independente em relação ao Partido Democrático Trabalhista. O movimento está mais voltado para Brizola do que para o PDT.
} 
deixaram o partido ${ }^{71}$ são reveladores para corroborar com tal desencaixe entre o partido oficial e o movimento espontâneo da Brizolândia. Esse movimento político servia a um partido político, mas muito mais ao seu líder, e utilizava como palanque principal as escadarias do Palácio Pedro Ernesto para uma plateia heterogênea e afetada pela carestia da década de 1980. Assim foi a Brizolândia que mesmo utilizando-se, muitas vezes, de artimanhas nada republicanas (como a posse de um espaço público onde passava a ser proibido o contraditório) estabeleceu uma nova forma de fazer política na rua, ao criar um campo discursivo capaz de promover ideias, cenários idealizados e caminhos de rompimento com o instituído e que se torna mais uma característica da capitalidade carioca que emerge da importante relação entre símbolos espacializados, espaços de memórias e ideais entre o ufano, o pragmático e o utópico e que perpetuaram Leonel Brizola no território carioca e no imaginário nacional.

Outro aspecto do movimento deflagrado em apoio a Brizola é que o líder trabalhista não tinha nenhuma ingerência sobre o mesmo, não exerceu qualquer tipo de influência direta sobre sua criação e, principalmente na forma como agia. Como ilustra Sento-Sé (1999) "até onde tenho notícias, é o primeiro movimento com alguma duração que leva o nome do líder a que se filia sem tê-lo como mentor ou dirigente regular" (p.304).

A Brizolândia transformou a praça em um "comitê" de campanha a céu aberto onde era possível fazer inserções junto à estrutura funcional do PDT. No entanto, não era uma forma de fazer política no estilo fisiológico: aproximações com alguns setores do partido eram indesejadas pelas lideranças do movimento, cujo objetivo central era o de militar em torno de Brizola e do trabalhismo. Nesse sentido, afirma Sento-Sé (1999):

O tipo de dominação carismática é definido pela adesão a um líder a quem são atribuídos poderes extraordinários e inexistentes nos homens comuns. Segundo Weber, o líder é dotado de um forte poder de comunicação, o que permite o estabelecimento de um canal de interação direta entre ele e as massas, mediante o qual são desencadeadas emoções e paixões (motivações

\footnotetext{
${ }^{71} \mathrm{Em}$ eleições proporcionais para deputados, membros da Brizolândia apoiaram candidatos que mudaram de legenda pelo seu passado pedetista e, também brizolista, mostrando que a questão partidária muitas vezes está aquém da adesão à liderança de Brizola.
} 
preferenciais da ação das massas), gerando estados próximos o êxtase. (p.23)

A Brizolândia se tornou, portanto, um símbolo do brizolismo e, assim como o espaço público, tem sua demarcação estabelecida nos territórios urbanos (SERPA, 2004), o movimento estabelecido na Praça Floriano, pode ser considerado como um fenômeno também urbano e o brizolismo uma diretriz política e uma marca carioca, que ditou ao longo de sucessivos governos que foram eleitos posteriormente na cidade e no estado do Rio de Janeiro, um legado com relação à forma e o conteúdo de fazer política, na metrópole carioca e no espaço fluminense.

$\mathrm{Na}$ imagem dezenove observamos integrantes do Partido Democrático Trabalhista nas escadarias do Palácio Pedro Ernesto. Eles são de vários movimentos do partido e buscam retomar as atividades e discussões pedetistas realizadas na Cinelândia. No entanto, uma das dificuldades encontradas pelo movimento é a fragmentação interna e, também a perda de consistência em torno de uma liderança que represente o trabalhismo.

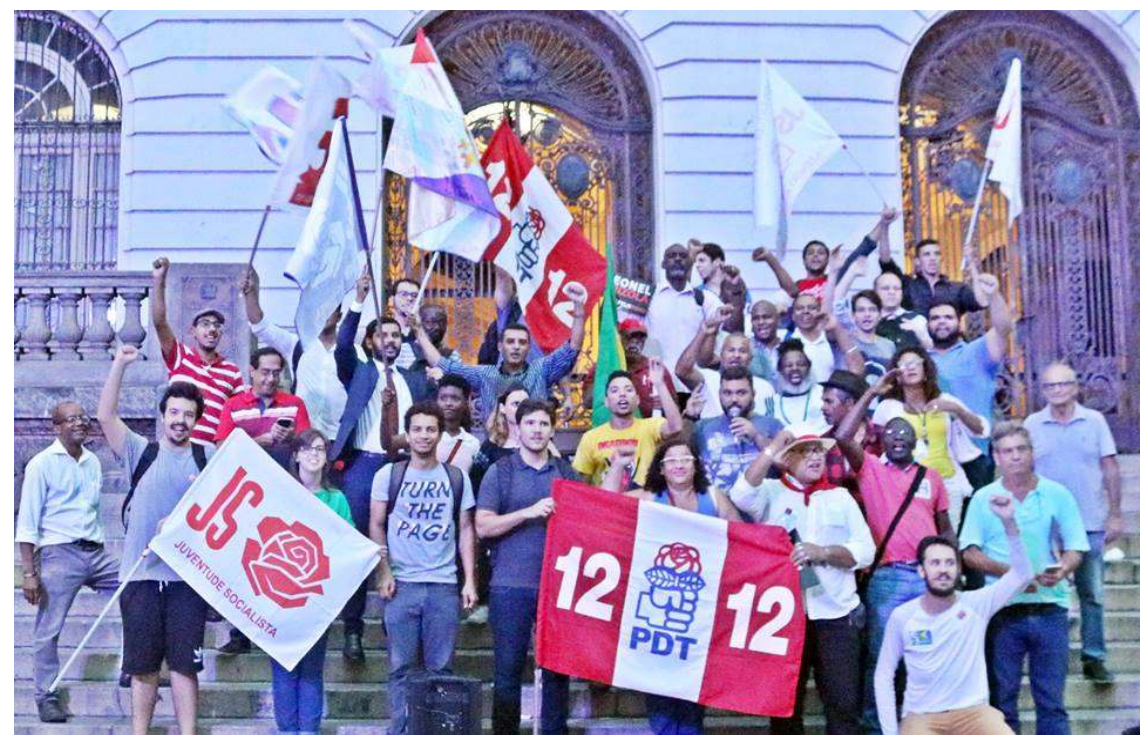

Imagem 19: Brizolistas ocupando as escadarias do Palácio Pedro Ernesto, um dos locais que os integrantes da Brizolândia utilizavam para fazer campanha para Brizola.

Fonte: www.pdt.org.br. Acessado em: 21/07/2021.

Apesar de não ser um movimento diretamente vinculado ao partido, os brizolistas da Brizolândia, protagonizaram ações políticas que questionaram Brizola, então eleito. O cerne da questão foi quando o então governador estabeleceu alianças com políticos chaguistas para formar arranjos que permitissem a governabilidade. Esse processo desencadeou forte oposição dos integrantes da 
Brizolândia em uma resistência conhecida como 'A Brizolândia contra Brizola', movimento que, mesmo sem fazer parte da política partidária ${ }^{72}$, questionou a aliança costurada por Brizola e ratificada pelos diretórios pedetistas. Porém, como bem afirma Souza (1993):

Brizola compreendia o drama dos intrépidos militantes da Brizolândia. Ele mesmo já foi um político assim. Mas o que se lhe apresentava como um problema político, no momento, era governar com os chaguistas ou não governar, isto é, exercer ou não o mandato que o povo lhe outorgara. Brizola convocou os líderes da Brizolândia e de outras organizações de base e explicou a conjuntura política, do programa de governo e dos obstáculos criados pela representação insuficiente na Assembleia Legislativa. (p.50)

Apesar de o movimento da praça não existir mais, é bastante simbólico para os brizolistas e pedetistas formalizarem manifestações na Cinelândia sobre temáticas e pontos defendidos por Brizola. Isso garante a continuidade da importância simbólica desse espaço público para os brizolistas e o brizolismo, que ainda tem no Rio de Janeiro o seu principal território de atuação política. Os acontecimentos políticos no Brasil, vigentes nos últimos anos, as manifestações de brizolistas na praça têm sido mais frequentes por parte dos pedetistas, que buscam se reapropriar desse espaço.

Os brizolistas observam na praça um espaço de pertencimento daqueles que acreditam na agenda política idealizada por Brizola, uma possibilidade de mudança de paradigma na política brasileira. A diferença da tentativa de ocupação atual é que não temos mais um movimento espontâneo, mas promovido pelo partido.

\footnotetext{
${ }^{72}$ Quando me refiro a estar fora da política partidária, estou querendo dizer que as lideranças do PDT, através de seus diretórios apoiaram a coalizão partidária com o PMDB do estado do Rio de Janeiro, para que alcançasse a governabilidade, porém o movimento popular da Brizolândia não fazia parte do sistema político partidário.
} 


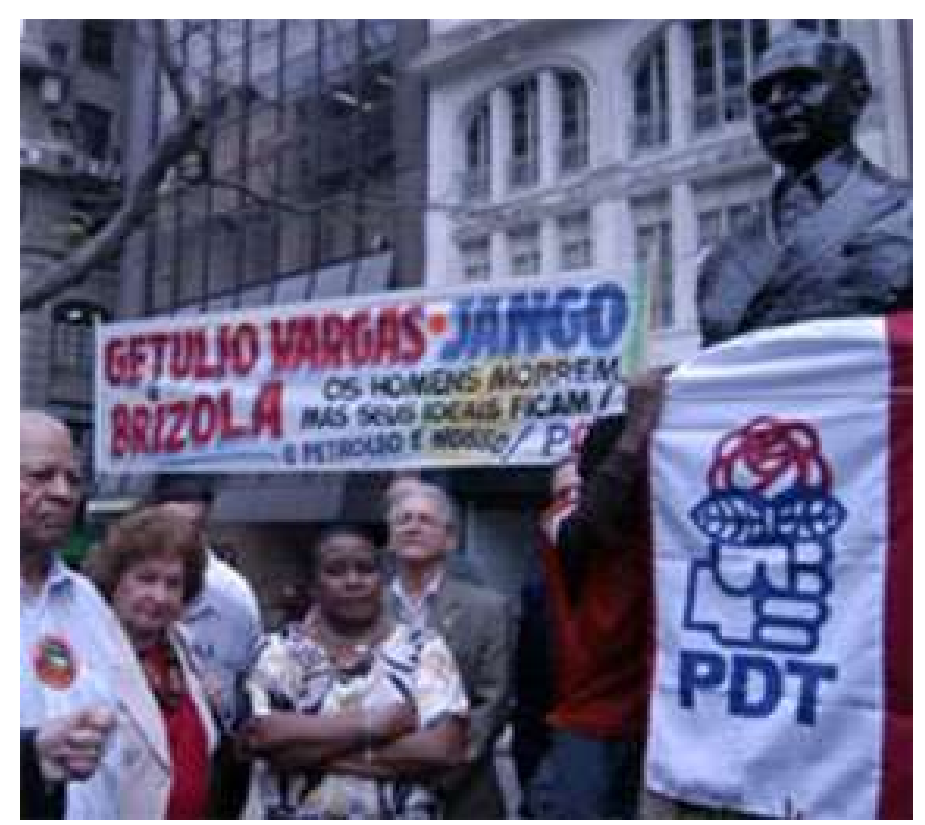

Imagem 20: Homenagem a lideranças trabalhistas e nacionalistas. Fonte: blogdogarotinho.com.br. Acessado em: 21/07/2021.

Recentemente outra manifestação ganhou corpo entre os pedetistas e brizolistas nesse espaço público, é a presença do bloco 'Órfãos do Brizola', que, apesar de não fazer suas apresentações na Cinelândia, tem na praça uma das concentrações para aqueles que frequentam e festejam politicamente através dos seus enredos homenageando Brizola e suas políticas públicas. Também utilizam o espaço público para suas manifestações carnavalescas para denunciar questões na política brasileira que são importantes para o funcionamento do próprio poder público. Na imagem vinte um, temos o símbolo do bloco.

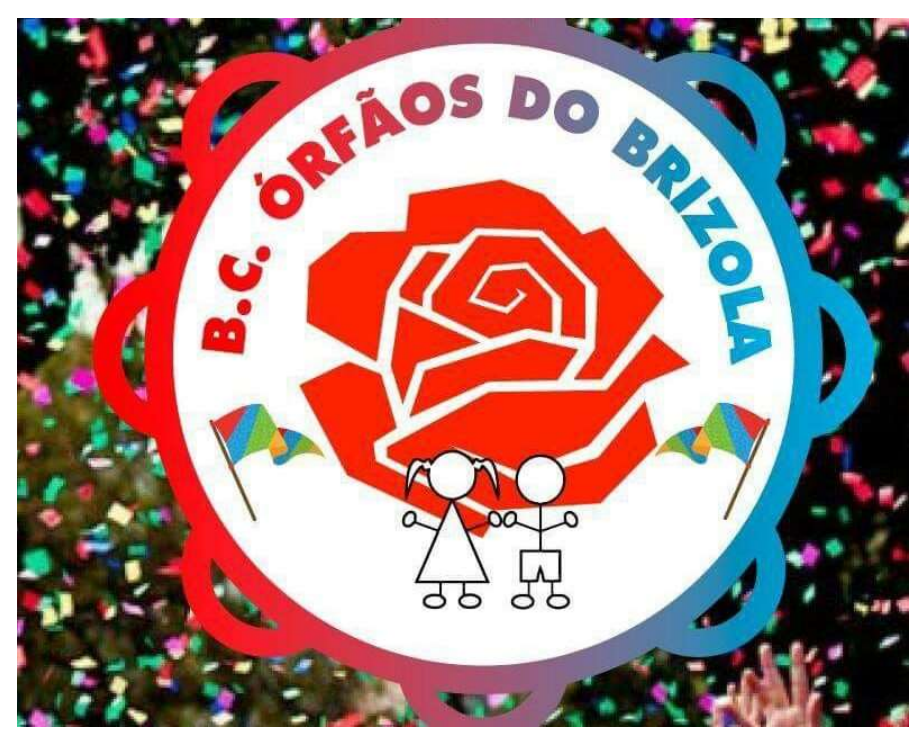

Imagem 21: Símbolo do Bloco Carnavalesco Órfãos do Brizola. Fonte: www.pdt.org.br. Acessado em: 21/07/2021. 


\subsubsection{Brizolândia: a relevância da praça para o movimento político}

As praças públicas são espaços livres onde qualquer cidadão pode utilizar enquanto instrumento público. São espaços de passagem, do encontro, do lazer, do ócio, de festas, de comícios, de manifestações e de campanhas políticas. Apresentam, portanto, múltiplos usos, que podem ser observados ao longo do dia e também de acordo com a configuração morfológica da praça.

A configuração das praças e a localização são variáveis que influenciam a diferenciação desses espaços segundo os usos. Por isso, assumem diferentes tipologias, que estão referenciadas a sua localização. No quadro sete, elaborado a partir das conclusões de Andrade e Batista (2015), acerca das praças, temos a seguinte tipologia:

Quadro 7: tipos de praças

\begin{tabular}{|c|c|}
\hline \multicolumn{2}{|c|}{ Tipos de Praças } \\
\hline Praças de bairros & Praças Centrais \\
\hline Uso mais limitado: & Combinam diferentes usos: \\
Lazer local & Turístico \\
Recreação & Simbólico \\
Turístico & Eventos oficiais \\
& Manifestações \\
\hline
\end{tabular}

Fonte: elaborado pelo autor, a partir de Andrade e Baptista, 2015.

De acordo com a localização, com a centralidade e pela importância simbólica no centro histórico do Rio de Janeiro, a Cinelândia se configura como uma praça central. As características apresentadas por espaços como esse, emprestam aos movimentos sociais e às manifestações realizadas na sua área de perceptibilidade, grande visibilidade. Dessa maneira há a possibilidade de angariar simpatizantes, observadores e de transmitir a mensagem que desejam.

Portanto, para movimentos conforme a Brizolândia, a apropriação desse tipo de espaço, funciona como uma "via de mão dupla", em outras palavras, o movimento se apossa do espaço, mas ao mesmo tempo este empresta seu capital simbólico e também o que representa para a cidade, pois a centralidade do lugar é importante para tornar a mensagem mais evidente àqueles que se intenciona cooptar. 
Os brizolistas, portanto, não se apropriaram somente do espaço, mas também da dimensão simbólica presente na Cinelândia, representada em sua monumentalidade, na centralidade e no tráfego de pessoas durante os dias de semana, fator fundamental para as pretensões do movimento que se instalou na praça.

No entanto, apesar de todas as representações que a Cinelândia compreende o que tornou esse espaço um território dos brizolistas e do brizolismo? Que representações criadas a partir desse grupo tornaram a praça, com importância histórica e política, um espaço de representações de um movimento para apoiar a liderança e as ideias difundidas por Leonel Brizola após seu retorno ao Brasil depois de quinze anos de exílio?

Moscovici (2009), o fundador da psicologia social, trás algumas considerações importantes para tentar responder aos questionamentos anteriores, a partir da teoria das representações sociais. O principal teórico desse pensamento menciona que dois mecanismos são importantes para criação das representações sociais: a ancoragem e a objetivação.

Sobre os dois mecanismos, Moscovici (2009):

\begin{abstract}
O primeiro mecanismo tenta "ancora" ideias estranhas, reduzilas a categorias e imagens comuns, colocá-las em um contexto familiar. O objetivo do segundo mecanismo é objetivá-los, isto é, transformar algo abstrato em algo quase concreto, transferir o que está em mente em algo que existe no mundo físico. Estes mecanismos transformam o não familiar em familiar. (p.42)
\end{abstract}

No contexto que a Brizolândia se formou, período que antecede as eleições de 1982, a ocupação de um espaço público, foi fundamental para o movimento. Para que seu propósito eleger Brizola, tivesse êxito, havia a necessidade de divulgar o discurso de Brizola e de seu "Novo Trabalhismo", além de tornar seu programa conhecido para os transeuntes. Necessitaria de sair do campo das abstrações e familiarizar seu discurso com o povo.

A expressão povo era considerada muito cara para os brizolistas, porque se tratava da forma como os seguidores de Brizola gostavam de ser chamados e, de forma alguma queriam ser denominados ou reconhecidos como massa, pois "ser massa corresponde a ser não povo. Daí a veemência com que os frequentadores da 
Brizolândia afirmam ser povo. Ser parte de uma elite consciente, que adquiriu e cultiva a virtude pública” (SENTO-SÉ, 1999).

Para tornar Brizola um candidato do povo foi necessário construir um discurso de fácil compreensão, traduzir a Carta de Lisboa, para um enredo carioca e brasileiro. Assim, foi necessário simplificar o "Novo Trabalhismo" traduzindo este através de categorias que pudessem ser prontamente apreendidas pela população e, somado a isso utilizar a centralidade do espaço da praça para estabelecer uma comunicação direta com os pedestres e transeuntes que frequentavam a Cinelândia, com uma política baseada na inorganicidade com uma linguagem direta e não seguindo diretrizes político partidárias.

No quadro oito, apresento algumas categorias que dão concretude ao discurso brizolista e à figura de Brizola, com a construção de imagens que permitiram um processo de ancoragem e a (re)construção do líder trabalhista como 'homem do povo' e que governaria para o mesmo.

Quadro 8: Representações sobre Brizola

\begin{tabular}{cc}
\hline \multicolumn{2}{c}{ Representações sobre Brizola } \\
\hline Categorias & Imagens comuns \\
Popular & Homem do povo consegue se \\
cuta pelo povo & Político que vai lutar pelos pobres, dar \\
& casa, educação e saúde \\
Não tem medo de poderosos & Enfrenta a rede Globo \\
\hline
\end{tabular}

Fonte: elaborado pelo autor: 2021 a partir do livro Um Grito na Praça: 1993

Segundo as categorias estabelecidas que simplificassem a imagem de Brizola e as representações criadas a partir delas, foi concebido ao político, um campo de significações, como aquele que faria pelos mais necessitados, pelo povo, lutaria contra as injustiças, portanto os discursos criados para o candidato nas mensagens e rodas de conversas realizadas na Brizolândia desenvolveram um campo de representações de fácil assimilação ${ }^{73}$. A praça torna-se um espaço de

\footnotetext{
${ }^{73} \mathrm{De}$ acordo com a teoria das representações sociais as categorias e imagens construídas tanto podem ser positivas quanto negativas, portanto os sentidos conferidos positivamente a Brizola também formaram as imagens inversas acerca do "caudilho". O discurso do antibrizolismo usou dos mesmos
} 
assimilação do discurso do brizolismo, um campo onde as representações sobre o líder trabalhista era apresentado para quem parasse ou estivesse apenas circulando.

Uma consideração interessante sobre os espaços simbólicos, relacionados a pessoas que são figuras públicas como Brizola, foi formulada por Jovchelovitch (2000) quando afirma que "como as pessoas constroem sobre representações na vida pública e como essas representações se transformam em espaços simbólicos".

Nesse caso é possível considerar que a figura de Brizola e as representações sobre sua imagem, além do discurso elaborado e veiculado ao ex-governador criaram uma representação que se ancorou em um espaço público carioca, gerando outro simbolismo, um espaço brizolista.

A Brizolândia e sua apropriação da Cinelândia, espaço público institucionalizado no urbano carioca, dotada de símbolos, de intensa circulação de pessoas em que os diferentes se olham, cruzam, mas que partilham um mesmo espaço, na maioria das vezes de forma harmônica, subverte essa ordem, pois busca territorializá-lo, através da ação de seus integrantes, de suas abordagens e da barraca construída nas proximidades da escadaria do Palácio Pedro Ernesto. Ao redor dela como evidenciado por SOUZA (1993) e SENTO-SÉ (1999) as reuniões e discussões sobre o processo eleitoral de 1982 e as críticas dirigidas tanto a adversários como a lideranças do Partido Democrático Trabalhista eram realizadas de forma mais contundente.

\subsection{Brizolândia: apropriação e subversão do espaço público}

O espaço público é marcado pela pluralidade, por ser um ambiente em que diferentes circulam e usam. Muitas vezes assinalado pela impessoalidade, pelo anonimato e, até mesmo, pela indiferença.

A partir de suas características, devemos entender esse espaço através de uma visão polivalente e pelos diferentes significados que são atribuídos ao mesmo, em conformidade com as representações atribuídas pelos seus frequentadores, pois

mecanismos para fazer oposição a Brizola. Muitas vezes essa teoria sofre críticas por acharem que ela gera um binarismo de posições. 
os usos e sentidos que podem ser dados, parte também da subjetividade daqueles que o acessam.

Dessa forma, um dos principais traços observados nos espaços classificados como públicos é a possibilidade de acessibilidade a todos os cidadãos, sem nenhum tipo de distinção. Estamos exprimindo sobre um espaço de compartilhamento entre os diferentes, que nos remetem a oportunidade de afirmar que não devem ou não deveriam ser apropriados por nenhum tipo de grupo para um propósito particular.

Levando em conta a acessibilidade desses espaços e suas múltiplas formas de utilização, o fato de um espaço ser público, não significa que haja permissividade quanto ao uso livre. Um espaço público implica o compartilhamento entre os diferentes, por isso existem regras e normas estabelecidas com a finalidade de evitar conflitos, é exatamente isso que o torna um espaço do poder instituído.

Quando um determinado grupo, seja para qual finalidade for, se apropria de um espaço público, há a subversão do mesmo, pelo traspassamento das regras instituídas pelo poder público, rompendo com o convívio entre os diferentes e, até mesmo a indiferença que permeia os seus frequentadores e 'usadores' e, com essa postura, dificultando o compartilhamento.

Devemos entender a apropriação como um ato em que um determinado grupo ou grupos se apossam de um espaço público, sem que o pertença, tornando 'privado' um espaço em que intercâmbios sociais ocorrem e as trocas entre diferentes acontecem.

A propósito das afirmações sobre o espaço público, analiso a Brizolândia e a ocupação realizada pelos seus integrantes sobre a Praça Floriano Peixoto (Cinelândia), como um movimento que causou uma interrupção das regras estabelecidas pelo poder público no tocante ao uso da praça, pois através de suas ações 'políticas' não permitiu a coexistência de outros grupos, vinculados a segmentos políticos partidários que não tivessem o mesmo objetivo, o de eleger Leonel Brizola, os candidatos pedetistas e difundir o trabalhismo.

A ordem estabelecida pelo movimento presente na Cinelândia promoveu a refuncionalização desse espaço público como um lugar onde a possibilidade do encontro e da manifestação geraram uma socialização e uma dimensão simbólica, 
levando a outro tipo de acessibilidade ${ }^{74}$ ao serem selecionados os que podem ou não participar do seu uso. Nesse caso, ocorre a "privatização" público e a quebra do princípio de alteridade, uma vez que o outro não será aceito, pelo fato de não partilhar dos mesmos valores exercidos pelo grupo majoritário.

O movimento que durou doze anos na Cinelândia, realizado por brizolistas, se apropriou desse espaço público, determinando uma territorialização da praça, seja por repelir qualquer grupo com propósitos semelhantes ou pela demarcação concreta - com uma barraca com fotos, cartazes e publicações sobre Brizola, seja por ações não republicanas - e pela visibilidade que buscava dar ao líder trabalhista com divulgação de suas propostas políticas.

A utilização dos espaços públicos, muitas vezes sugere distintas conformações, entretanto a forma e a condição das práticas realizadas no cotidiano podem gerar tensões ou não nesses espaços. De certa forma, o uso implica em apropriação, no entanto, uma finalidade específica de apropriação pode romper com a condição estabelecida pelo poder instituído para esses espaços.

Caccia (2011) fez uma tipologia quanto aos tipos de apropriações que são realizadas nos espaços públicos, a partir dos diferentes usos. No quadro nove é possível observar as duas formas de apropriação.

Quadro 9: Apropriações do espaço público

Apropriações do espaço público

\begin{tabular}{c|c}
\hline Corriqueira & Coletiva \\
\hline Individual & Caráter político contestatório \\
Cotidiano & Manifestações \\
Ato de viver & Reivindicações \\
Caminhar & \\
Direito de ir e vir & \\
\hline
\end{tabular}

Fonte: elaborado pelo autor, 2021, a partir de Caccia (2011)

O quadro nove procura evidenciar que sempre há uma apropriação do espaço público, o que difere são as formas, pois é a partir delas que tensões entre

\footnotetext{
${ }^{74}$ Recomenda-se a leitura da reflexão de Serpa (2004) sobre o sentido da acessibilidade espacial em ambientes cujas ideias são difusas e opostas.
} 
grupos serão estabelecidas entre aqueles que frequentam e ocupam esses de espaços e aqueles que também se apropriam do mesmo, porém retirando, muitas vezes, seu simples caráter de fruição, causando perturbações.

Os usos que são feitos no cotidiano em relação às praças ${ }^{75}$, se diferem de acordo com os vários grupos sociais que frequentam esse espaço, e as variáveis são inúmeras, como por exemplo, a faixa etária, o estilo de vida, os horários, dentre outros.

Nas apropriações classificadas como corriqueira, seus frequentadores expõe um valor de lugar, pois serve como espaço do encontro, de múltiplos usos, de fruições e de interações. Nesse contexto, temos um exemplo de apropriação que pode ser classificada como positiva, não transpassando sua condição de público, sendo este espaço aberto, de circulação irrestrita, de interação social entre pessoas diferentes e que possibilita a existência da vida coletiva.

Quanto às praças de uso coletivo, o espaço público tem o papel de visibilizar ou criar visibilidade para um determinado grupo, com o objetivo de tornar suas manifestações ou reivindicações mais amplas, sugerindo através das propostas a conquista de metas que ultrapassam os limites do espaço público onde o ato é realizado.

As manifestações e reivindicações realizadas no espaço público, muitas vezes ultrapassam os limites territoriais, constituindo o que Sobarzo (2008) chama de "salto escalar" (p.107). No caso da Brizolândia, a mobilidade verificada no espaço onde se instalou, procurou visibilizar Brizola e suas propostas, para escalas maiores do que a praça, ultrapassando seus limites para toda a cidade do Rio de Janeiro.

O movimento realizado pelos brizolistas, a Brizolândia, destoa, em parte, com algumas características presentes na categoria nomeada como coletiva, mesmo estando inserido nela. Algumas considerações podem confirmar essa assertiva.

Os integrantes da Brizolândia não admitiam que nenhum tipo de campanha ou manifestação política fosse realizado na Cinelândia, somente para Brizola ou os

\footnotetext{
${ }^{75}$ Enfatizo as praças, porque o movimento criado por brizolistas se estabeleceu em uma praça público e se apropriou desse espaço.
} 
candidatos do PDT. O espaço da praça, que deveria ser caracterizado pela comunicação polissêmica, perde esse aspecto, pois não franqueava essa condição para nenhuma corrente política ou que outro partido pudesse utilizar o mesmo espaço.

Uma questão relevante a essa apropriação foi a demarcação do espaço com a barraca nas proximidades da escadaria do Palácio Pedro Ernesto, estabelecendo uma territorialização ${ }^{76}$ desse local por parte dos brizolistas. A atuação de seus integrantes, muitas vezes realizada por meio da violência tanto física quanto verbal e pela intimidação, retirou do espaço público sua condição de reunião das diferenças. Originou o que chamei como título desta seção - 'a subversão do espaço público' - pela tentativa de submissão deste a um grupo que se apossou do mesmo.

Quanto à condição de espaço público no que se refere ao seu uso e as regras as quais deve estar submetido, as palavras de Gomes (2002) sobre suas características são bastante elucidativas. De acordo com o geógrafo: "o espaço público é o lugar das indiferenças, ou seja, onde as afinidades sociais, os jogos de prestígio, as diferenças, quaisquer que sejam, devem se submeter às regras da civilidade" (p.162).

No entanto, a Brizolândia seguiu o oposto do que foi mencionado, a começar pela forma de atuação do movimento, quebrou todas as regras de civilidade, pois retirou a mobilidade e a acessibilidade de outros grupos políticos para utilização do espaço para fins políticos e partidários. Desordenou a esfera pública contrariando a afirmação de Moura (2016) em que para este: “os espaços públicos referem-se a locais que é de todos em oposição ao espaço privado. Conjunto de espaços que interligam as diversas partes que constituem as cidades, possibilitando sua existência e da sua vida coletiva”. (p.16)

Dessa forma, a Cinelândia, travestida de Brizolândia ganhou outra forma e conteúdo (SANTOS, 1986), pois esse movimento, também conhecido como "Um grito na praça", atribuiu outros significados e representações para o espaço público.

\footnotetext{
76، O PMDB foi o primeiro a tentar armar barraca na Marechal Floriano. Chegou mesmo a montar sua arapuca, mas o povão sob o comando de Pernambuco (líder do movimento da Brizolândia), fez um arrastão em câmara lenta. Militantes ativistas e povo se deram as mãos e foram avançando, devagarinho, rumo da barraca do invasor, gritando baixo: tira, tira, tira... A barraca foi retirada as pressas" (SOUZA, 1993, p.35)
} 
Também é importante destacar o papel da praça dentro do seu conteúdo morfológico, pois como pode ter diferentes composições e usos no seu cotidiano, a praça deve caracterizar-se por distintas formas e funções, de acordo com os horários do dia, dias da semana, e outras temporalidades que marcam as diferenças das funções e usos de um espaço público.

Após as considerações envolvendo a apropriação da Cinelândia, um espaço público, pelos brizolistas, vamos analisar se é possível afirmar que este espaço possa ser classificado como político ou não.

\subsection{A Brizolândia: espaço político ou "apolítico"?}

Como foi visto na seção anterior o movimento estabelecido na Cinelândia em 1982, se apossou de um espaço público, privando este de sua principal característica que é a impessoalidade e o uso livre de todos que circulam ou frequentam.

O movimento brizolista tinha um objetivo claro, eleger Leonel Brizola e fazer do espaço da praça um reduto eleitoral de pedetistas, brizolistas e trabalhistas. A Praça Marechal Floriano, ou pelo menos parte dela, passou a ter seu espaço utilizado para uma finalidade específica a partir de uma finalidade imposta por um grupo.

A atuação do movimento foi alvo de críticas por não admitir a pluralidade e o livre exercício de outros grupos políticos se expressarem neste espaço. É de acordo com o uso estabelecido pelos brizolistas que se faz necessário questionar sobre esse local. Podemos classificar a praça, apropriada pelos brizolistas como um espaço político ou não?

Outra indagação vai exatamente, no caminho inverso. Será a Brizolândia um espaço, onde as práticas realizadas podem ser classificadas como apolíticas quando verificamos a forma como os brizolistas, através de atos não republicanos, territorializavam a praça?

O espaço público pelas suas características de interação e de comunicação faz parte do funcionamento da própria democracia, devido à diversidade de usos e 
funções que pode abrigar um espaço da alteridade e da acessibilidade a todos. Os espaços públicos podem assumir formas e conteúdos diversos, pois segundo Santos (1986) "o seu significado é variável, na medida em que o movimento social lhes atribui em cada momento, funções diferentes do todo social” (p.42).

Para Borja (2003) "espaços públicos estão relacionados diretamente ao urbano, faz parte da cidade e funda princípios da cidadania, na medida em que permite a convivência entre os diferentes, cria espaços de sociabilidade e da possibilidade de uso comum sem conflitos" (p.22). O espaço público é o espaço do poder instituído, pois suas regras são estabelecidas pelo mesmo. Dessa forma, a configuração espacial, os equipamentos, foram desesnvolvidos para promover usos e interações que permitam o convívio com a diversidade. No esquema seis, temos a concepção de espaço público por Borja (2003):

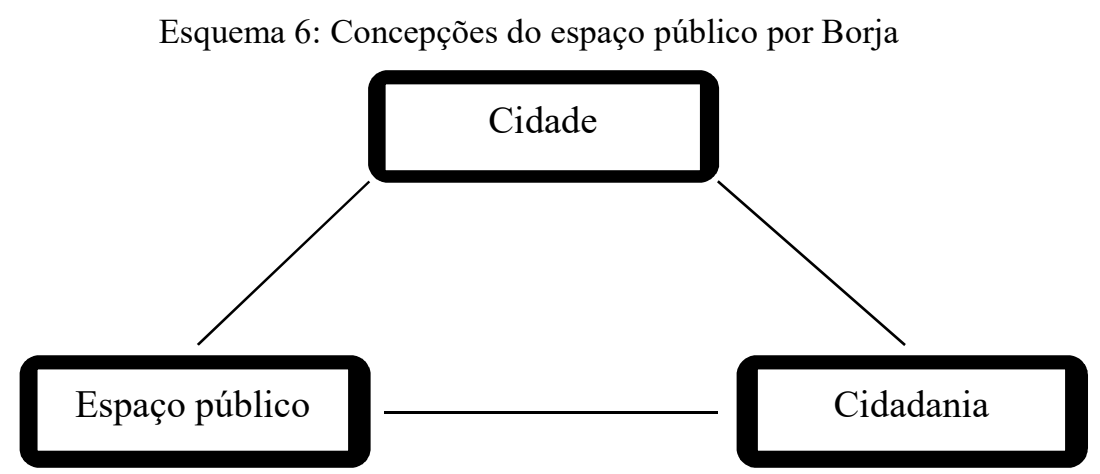

Fonte: Elaborado pelo autor, 2021, a partir de Borja (2003).

Consoante com o esquema acima, é possível perceber que não há isolamento entre os termos e que os espaços públicos, como um espaço da cidade, da socialização, das diferenças, do uso público, tem a universalidade como um de seus principais atributos. Desta maneira, é um espaço formador de cidadania, pois aqueles que se utilizam dele devem respeitar normas e regras de convivência, considerando os limites que são institucionalizados.

Como foi destacado anteriormente, espaços como as praças têm usos com diferentes significações para aqueles que frequentam esses ambientes. A própria praça é um todo dividido em várias partes, que apresenta formas e conteúdos distintos. Áreas para crianças, mesas para jogos utilizadas por idosos, espaços para cães brincarem e, junto a isso, temos os transeuntes e aqueles que apenas se sentam 
nos bancos das praças com o intuito de ver o 'tempo passar'. Outras conformações acontecem ao longo do dia, que não vem ao caso serem mencionadas. A intenção é somente mostrar que as apropriações realizadas sobre esses espaços concebem que os mesmos tenham diferentes campos de significação, portanto, assumam diferentes formas-conteúdos.

No caso da Cinelândia, uma praça central, sua funcionalidade não é a mesma de uma praça de bairro. Os seus frequentadores são mais ecléticos, na maioria das vezes não são residentes dos locais onde estão localizadas. Pela sua centralidade apresenta grande quantidade de transeuntes, fator relevante para que os brizolistas se apossassem desse espaço.

O espaço da Praça Floriano Peixoto, como espaço físico de uma morfologia penetrável pelo cotidiano do centro do Rio, faz parte da dimensão do feito memorável, já que está na ordem simbólica da cidade do Rio de Janeiro, integra uma das representações e do universo imagético da metrópole carioca, sendo um dos fatores que transforma o espaço público em político, apesar dessas duas dimensões não se excluírem. Essa não exclusão pode ser corroborada pela afirmação de que o espaço público é a condição necessária para o nascimento do espaço político (ARENDT, 1972).

A apropriação desse espaço pelos brizolistas constitui uma centralidade. $\mathrm{O}$ brizolismo, na Cinelândia, ganha uma dimensão simbólica na política carioca e fluminense. A apropriação da praça enquanto lócus da vida política traz ao brizolismo visibilidade. A partir desse espaço, as ações políticas nele colocadas, 'ganharam' a rua e demandaram atenção dos passantes - que trafegavam em grande número nesse espaço.

O sentido do que é trazido em público tem como principal intenção ganhar aparência e ser visibilizado. A praça, portanto será qualificada como um espaço de aparição. Esse espaço, tornado político pelo conteúdo e ação daquilo que se pretende evidenciar, terá uma intencionalidade de acordo com as ações de um determinado segmento e grupo político. 
O espaço público pode ser afirmado como a base de sustentação para que a ação política ocorra. Neste sentido, como afirma Gomes (2013) “o espaço é um instrumento que faz ver, que torna visível".

Ainda de acordo com Gomes, 2013:

(...) a visibilidade é um fenômeno que apresenta uma incontornável geograficidade cuja magnitude e alcance dependem de três elementos principais: a morfologia do sítio, que deve ser capaz de garantir convergência de olhares e a desejada captura da atenção; a existência de um público, formado por observadores sensíveis aos novo sentidos nascidos da associação entre o lugar e o evento que se apresenta e cujos olhares estejam atraídos e concentrados nestas áreas; e da produção de uma narrativa, isto é, leituras dos sentidos que emergem do contexto espacial dentro do qual se inscreve o fenômeno (p.37-8).

A partir da visibilidade garantida pela localização privilegiada da praça, o movimento trouxe as demandas políticas, os programas e as propostas para Cinelândia. Procurava também aumentar o conhecimento sobre a imagem de Brizola. O objetivo foi tornar esse espaço um lugar da ação política do brizolismo. Bucci (2016) apresenta algumas considerações relevantes sobre o espaço político, como espaços da visibilidade e do desempenho político. Vamos às palavras do autor sobre o assunto:

\footnotetext{
Estes espaços são espaços da visibilidade e da performance política em bruto, ou seja, como forma que precisava ser interpretada, sua escala e métrica variáveis instáveis, mas seus efeitos como condição de substância podem afetar profundamente algumas decisões políticas de prazo mais longo, estabelecendo um nexo entre a praça e o palácio, ou mais objetivamente entre a sociedade e seus governantes. Estes são espaços de ação aberta de toda sociedade, qualidade intrínseca aos espaços escolhidos para manifestações, protestos, passeatas, ocupações e tudo mais que a imaginação dos ativistas sociais decidiu criar para alcançar seus objetivos.
}

Além da visibilidade e da performance, há outras formas de conferir a um espaço público a condição de político, principalmente quando há alteração de seu uso. Essas alterações proporcionam para o espaço outras rotinas que vão reproduzir novos condicionamentos para o espaço público, permitindo, segundo Castro (2018) "como passíveis de se qualificarem como espaços políticos quando invadidos por fenômenos da política que, temporariamente transforma sua natureza de lugar do 
encontro, do ver e do ser visto em palco de atividades que alteram suas rotinas" (p.25).

Tendo como referência a apropriação que a Brizolândia fez da Praça Floriano Peixoto, há uma transformação do espaço público em político, pois a atuação de seus integrantes alterou o uso de parte desse espaço com uma finalidade política específica. Essa finalidade só pode ser definida por atores que se apossam de um espaço, muitas vezes territorializando o mesmo.

Concordo com Castro (2018) quando argumenta sobre a incongruência dos argumentos que defendem a essência política no espaço público. Entretanto, o espaço público produz condições para existência do espaço político, exatamente pelo encontro, das diferenças e de interações diversas. O espaço público cria a possibilidade de formação do político, pois nele estão contidas as ações políticas realizadas por determinados atores que, como já mencionado, alteram sua rotina e, conforme Serpa (2004), “expressam modos de subjetivação não identitárias, em contraponto aos territórios familiares e de identificação comunitária" (p.22).

A praça, o espaço público que está sendo tratado como o espaço da ação política do brizolismo, observado através do movimento organizado pelos brizolistas que se apropriaram da Cinelândia, transformou-o em espaço em político, da competição eleitoral (DOWNS, 1957). Essa é, a propósito, uma das primeiras definições do que seria um espaço político. D’Alimonte (2003) se alinha a essa mesma definição, valorizando sua percepção a partir da política eleitoral afirmando que "entende esse espaço como área de conflito constituída na relação entre eleitores e partidos, num dado sistema político e num certo momento histórico" (p.392).

Na percepção dos brizolistas instalados na praça, fica perceptível o caráter eleitoral que foi assumido por este espaço após sua apropriação. Formou-se uma área de conflitos e tensões, de embates e cisões com outros grupos políticos e de ruptura com os valores instituídos para um espaço público.

No caso da Brizolândia, um espaço de representação do movimento em torno da figura de Leonel Brizola, posições, composições e exposições são importantes para o movimento brizolista. Não é à toa que foi escolhido um espaço 
aberto para que ele fosse realizado. A praça oferecia uma trama locacional por uma barraca montada em frente ao Teatro Municipal e às escadarias do Palácio Pedro Ernesto. Podemos alicerçar essa afirmação a partir de Gomes (2013) quando para este geógrafo "existe uma trama locacional, em que temos o arranjo físico das coisas, pessoas e fenômenos, do qual participam as imagens e representações visuais, assentadas em diferentes suportes e cujo desvelamento das coerências, lógicas e razões é função específica da Geografia" (p. 18-9). Neste caso, os espaços abertos são uma forma de classificação dos espaços políticos, caracterizados pela grande mobilização, possibilidade de angariar adesões e onde a ação política ganha mais visibilidade.

Castro (2017) vai fundamentar a diferença do espaço político de acordo com três tipos básicos, que interferem diretamente em seu uso, como veremos no quadro 10 :

Quadro 10: A classificação do espaços públicos
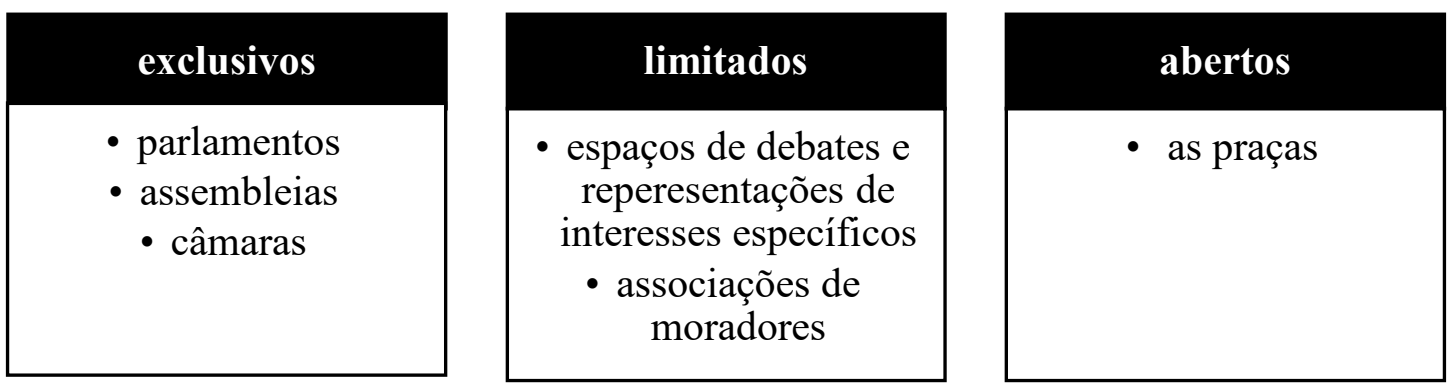

Fonte: Elaborado pelo autor, 2021, a partir de Castro, 2017.

Como evidenciado nos quadros, os espaços abertos são elementos espaciais que permitem a visibilidade, de forma mais transparente, daquilo que se busca mostrar, promovem a possibilidade de buscar mais adesões. São espaços políticos em que as regras e normas estabelecidas são mais flexíveis quanto a participação, pois não são dotados de formalidades.

Cornwall (2002) observa nos espaços políticos abertos como de movimentos e momentos efêmeros ${ }^{77}$. Para o autor, os movimentos realizados nas ruas e praças, lugares de convivência do cotidiano, tendem a não ser duradouros.

\footnotetext{
${ }^{77}$ Vários movimentos apresentam esse caráter efêmero, o que não é um fator de desqualificação dos mesmos. Muitos dependem de visibilidade, para que o apelo político tenha alguma forma de alcance. Como exemplos de movimentos efêmeros, podemos citar as manifestações de rua de junho de 2013, ocupação do Canecão e o das escolas públicas em São Paulo.
} 
Os movimentos realizados ocorrem por motivações específicas em um determinado período. No caso da Brizolândia, o movimento durou enquanto a força política do brizolismo e de Brizola, ainda era relevante na cidade e no estado do Rio de Janeiro.

Assim, a praça como espaço aberto no sentido lato, ou seja, aberto ao céu, ao tempo, à livre circulação, aberto à participação dos copresentes, apresenta uma configuração importante como espaço da ação política, pois se compõe como um espaço livre de obstáculos, aberto a qualquer tipo de manifestação.

O movimento da Brizolândia produziu elementos em um espaço público, que o transmutaram em um espaço político, na medida em que as práticas realizadas por seus integrantes mudaram a rotina de usos, criando um espaço de ação política de finalidade específica. Buscaram nos transeuntes e nos frequentadores adeptos para causa brizolista. O espaço da Brizolândia procurou fazer política, muitas vezes, atuando pela própria negação da política.

Há, porém, determinadas estratégias e relações ajustadas ao espaço da praça, a partir da forma de apropriação criada pelos brizolistas que se apossaram da "coisa pública”, não permitindo o contraditório e a pluralidade do exercício político. A intolerância foi uma das formas de ação política da Brizolândia contra adversários que não coadunavam com os seus propósitos e objetivos.

Nesse sentido, como classificar esse espaço de político? A indagação está vinculada ao sentido que os brizolistas da praça tinham em relação ao espaço, pois territorializaram a Cinelândia, não permitiam que nenhum outro grupo se estabelecesse e muitas vezes nem tivesse o direito de circular pela praça.

A Brizolândia foi um espaço delimitado por práticas espaciais, que limitava as ações políticas de outros grupos, retirando da esfera pública suas principais características, como a de ser o domínio do público, do espaço do discurso, sendo este pluralizado e que permita interações entre diferentes. Em um espaço público aberto como uma praça, a única coisa que pode limitar uma forma de manifestação, seria o uso de práticas violentas ou outras formas de coerção.

Sendo assim, o espaço público é a fonte geradora do espaço político, que pela sua lógica é marcado pelo dissenso. Porém, as práticas espacializadas pelo grupo estabelecido na Praça Floriano tinham outra forma de ação, marcado pelo 
primarismo político, uma forma de atuação que não pode ser classificada nem de esquerda e nem de direita e que procura corromper as regras do jogo político e muitas vezes suas práticas são baseadas na agressão. A apropriação realizada pelos brizolistas da praça pode ser vista por um viés negativo e pela forma de conduta em relação a outros grupos, subverteu tanto o espaço público quanto o político, pois não procura o debate e nem a diversidade, mas o embate.

Sobre a forma de fazer e observar a política, Sento-Sé (1999), apresenta uma posição que foi ao encontro ao modo como os integrantes da Brizolândia achavam que a política deveria ser feita. De acordo com as análises do autor citado:

\begin{abstract}
"a ênfase no conflito configura uma percepção da política marcada essencialmente pela guerra. A política é guerra, e a sua prática implica na formação de alianças e na definição de adversários. A Brizolândia foi criada como se levasse tal postulado ao pé da letra. Empenha-se em varrer seus adversários da Cinelândia, promovendo pancadarias célebres" (p.309).
\end{abstract}

A Brizolândia, assim como vários tipos de movimentos políticos e de manifestação, apresenta um caráter seletivo, correspondendo apenas àqueles que são participantes ou simpatizantes e possuem as mesmas intencionalidades. Nesse sentido, a dinâmica do que foi realizado na Cinelândia, não tinha como hábito o diálogo e a livre exposição do pensamento, mas somente a permissividade de concepções e ideais políticos que afirmassem o brizolismo.

A análise que faço sobre o movimento segue o seu padrão contraditório, mas que essa mesma contradição o alimenta. Assim, como o brizolismo e o antibrizolismo, o "grito na praça" realizado pelos brizolistas, marcou a oportunidade da formação de um espaço político, entretanto a forma como o grupo estabelecido agia, com o uso não público do espaço, pode ser considerado, como “apolítica” ou da negação da política.

A utilização do termo "apolítico", que não necessariamente significa desprovido de política, mas que não é marcado por uma postura dialógica e, sim pela busca do pensamento em uníssono e na impossibilidade, causada pelas estratégias de ação do grupo, afastam ou repelem aqueles que não têm as mesmas posições políticas ou bandeiras ideológicas de aproximação. 
Concluo que o movimento da Brizolândia não se encaixava fielmente ao que pode ser classificado como espaço político descrito por Castro (2017), pois houve a apropriação e territorialização do espaço por um grupo específico, com uma visão política não eclética, uma vez que mesmo seguindo uma liderança política e de sua agenda, não busca aproximações ou diálogo.

O movimento conhecido como Brizolândia tinha uma estratégia política bem definida: a ocupação e apropriação da praça. Os transeuntes que passavam e paravam para ouvir os discursos de seus integrantes eram atingidos chamando atenção para o discurso político em torno de um ideal que seus militantes acreditavam, mas também percebendo o momento que o país vivia, da abertura política e da importância das eleições majoritárias para prefeito e governador, além das proporcionais para deputados federal e estadual e de vereadores ${ }^{78}$.

Como movimento político em um espaço aberto, a Brizolândia pode até ser vista como um caso à parte, devido à sua longa duração - cerca de doze anos ocupando o mesmo espaço. $\mathrm{O}$ enfraquecimento e desaquecimento do movimento ocorreram em grande parte com a perda de espaço político de Brizola. Essa perda vem no ano (1994), quando o velho líder trabalhista perde seu segundo pleito eleitoral para presidência da República. A sucessão de derrotas alijou Brizola da vida política. Ainda vieram outras tentativas de ressuscitar politicamente. Em 1998, como vice de Lula, depois nas eleições para prefeito e vereador do Rio de Janeiro, mas os resultados foram novas derrotas e frustrações.

O movimento político que fincou suas raízes na Praça Floriano Peixoto, tinha como grande objetivo, levar as pessoas, transeuntes e cidadãos a uma conscientização partidária, num momento que estava sendo restabelecida a democracia no país, de resgatar a figura de Brizola, após seus quinze anos de exílio, de divulgar o trabalhismo que passou a ser chamado de brizolismo, durante seus governos no estado do Rio de Janeiro. Nada melhor para fazer isso do que em um espaço simbólico da metrópole carioca, da modernização do antigo Distrito Federal,

\footnotetext{
${ }^{78}$ É importante lembrar que no ano de 1982 só não foram realizadas eleições para presidência da República. Na verdade, as eleições para prefeitos e vereadores eram para ter sido em 1979, porém, o regime autoritário em mais uma das manobras de sístole e diástole da forma como faziam política preferiu adiar as eleições municipais, por isso foram colocadas nesse ano.
} 
um lugar dotado de centralidade e que espelha uma das heranças da capitalidade da 'Cidade Maravilhosa'.

A Brizolândia foi um movimento na Cinelândia que fez desse espaço um símbolo do brizolismo no Brasil, uma marca conferida ao cenário político da cidade do Rio de Janeiro durante doze anos e que muitos brizolistas saudosistas buscam resgatar, mesmo que não seja de forma física, mas através da memória. Como alguns brizolistas declaram 'esse é um dos espaços em que é possível afirmar que Brizola ainda vive'. 


\section{Considerações Finais}

Brizola e o brizolismo influenciaram a política fluminense, mas principalmente a carioca? A resposta para essa pergunta parece simples, posso me certificar que sim, através de vários vieses distintos. No entanto, argumento que essa influência pode ser observada a partir de diversos ângulos tanto por brizolistas como por antibrizolistas.

As análises discursivas acerca de Brizola apresentam uma natureza contraditória que alimentou sua capacidade de se reinventar na política do Rio de Janeiro, seja através dos seus admiradores ou mesmo daqueles que repudiam sua forma de entender e fazer política, bem como da execução das políticas públicas no período em que foi governador do estado do Rio de Janeiro por duas vezes.

No ano de 1979, com o fim do AI-5 (Ato Institucional, número 5) e a anistia dada aos exilados, Brizola retornou para o Brasil, com um projeto político formatado, escrito em junho de 1979, em Lisboa. Nesse período, o Brasil estava passando pelo processo de abertura, controlado pelo regime militar vigente no país, desde o golpe de 1964.

O documento, conhecido como Carta de Lisboa, estabelecia as diretrizes do que seria conhecido como Novo Trabalhismo, que diferia do trabalhismo pré-1964, devido às influências da socialdemocracia europeia, com a inclusão de pautas de inclusão, observando a situação do negro, da mulher e dos povos indígenas.

No mesmo ano em que o AI-5 foi extinto, o mesmo destino teve o Ato Institucional $\mathrm{N}^{\circ} 2$, que pôs fim ao sistema bipartidário, dominado pela ARENA (Aliança Nacional Renovadora) e pelo MDB (Movimento Democrático Nacional). Com o fim desse mecanismo imposto pela ditadura, houve intensa movimentação para a reorganização dos partidos políticos e o líder trabalhista tinha como meta principal reorganizar o antigo PTB (Partido Trabalhista Brasileiro).

A perda da legenda, entretanto, para a sobrinha de Vargas, Ivete Vargas, fez com que Brizola reorientasse suas pretensões partidárias e, no dia 26 de maio de 1980, foi fundado o Partido Democrático Trabalhista (PDT), em que seu regimento foi formulado tendo como fundamento a Carta de Lisboa. 
O Novo Trabalhismo foi, portanto, instalado na cidade do Rio de Janeiro e, Brizola, através da 'Cidade Maravilhosa', colocou o seu grande projeto político em prática. Para isso, era necessária uma estrutura política e territorial que desse visibilidade e difundisse os seus ideais e conteúdos programáticos.

Nessa perspectiva, escolha da Cidade Maravilhosa como domicílio político não foi aleatória, por alguns fatores, como: foi o último domicílio eleitoral de Brizola antes do exílio em que obteve a maior votação para deputado no território brasileiro, além disso, para o líder trabalhista, a metrópole carioca continuava sendo a "caixa de ressonância do Brasil".

Mesmo com a perda de sua condição institucional de capital da República, o Rio de Janeiro continuou dotado de grande centralidade política e cultural, fazendo com que os acontecimentos no seu território ganhassem eco por todo país. A capitalidade ainda exercida pela metrópole carioca foi fundamental para o projeto brizolista, porque havia nessa cidade uma importante dimensão política e espacial que permitiria a Brizola retornar ao jogo político nacional.

Retornar à cena política brasileira por meio da metrópole carioca, no mesmo local onde teve o seu último cargo antes do exílio, como deputado federal pela Guanabara, seria recuperar o 'fio da história' e, também a trajetória de trabalhistas históricos como Getúlio Vargas e João Goulart. Portanto, a definição pelo espaço carioca foi considerada relevante para um projeto eleitoral que tinha como meta principal o executivo federal.

O Rio de Janeiro, portanto, parafraseando a canção de Gilberto Gil, "continua sendo" e, nesse contexto o brizolismo atribuiu um novo significado e identidade para o espaço carioca. Cidade considerada difusora de movimentos políticos e de manifestações culturais que expressam o seu cosmopolitismo e se tornou um importante espaço de divulgação das práticas e políticas executadas a partir desse fenômeno político.

Se o brizolismo formou suas bases territoriais e eleitorais, principalmente na metrópole carioca, não menos importante foi a capitalidade e a memória da capitalidade ainda presente, para dar a sustentação e visibilidade ao brizolismo e ancorar esse movimento político com uma territorialização dos espaços tanto 
carioca quanto fluminense, permitindo através de suas políticas públicas conseguirem reconhecimento em todo espaço brasileiro.

Com o êxito de Brizola nas eleições para o governo do estado do Rio de Janeiro em 1982, derrotando máquinas políticas consolidadas, como o chaguismo e o amaralismo, teve início o governo pedetista, que se colocava como oposição ao governo de Brasília.

É pertinente lembrar que a vitória eleitoral de Brizola nas eleições para o governo do estado do Rio de Janeiro em 1982, representou o êxito do único candidato que não fazia parte do eixo PMDB (Partido da Mobilização Democrática Nacional) e do PDS (Partido da Democracia Social). Dessa forma, sob o signo da representação político-partidária o Partido Democrático Trabalhista (PDT) representava o "novo", quando comparado à estrutura e institucionalização da política partidária na cidade e no estado do Rio de Janeiro. Isso não significou, no entanto, uma ruptura, já que era necessário criar condições para governabilidade do espaço carioca e fluminense, fato que ficou evidenciado na composição do secretariado brizolista, com a entrada de membros ligados ao chaguismo.

O governo do estado do Rio de Janeiro e, mais particularmente a atuação do brizolismo na 'Cidade Maravilhosa' criou o efeito desejado para Brizola, de dotar seu discurso e suas políticas públicas de visibilidade nacional.

Creio que a cidade do Rio de Janeiro foi o grande "laboratório" de experiências que o novo trabalhismo concebido pelo ex-governador ganhou eco e amplitude em diferentes níveis escalares e que, de certa forma, fez a 'caixa de ressonância' ecoar por todo território nacional.

A vitória do brizolismo no Rio de Janeiro permite que algumas conclusões sejam verificadas, como:

- Uma nova 'geografia do voto' vai ganhar corpo na cidade e no estado do Rio de Janeiro;

- Novas representatividades e representações foram estabelecidas; 
- Uma nova dinâmica espacial na política carioca e fluminense foi estabelecida, através do uso de outras práticas políticas como a participação popular;

- Houve uma redefinição na geografia eleitoral do Rio de Janeiro;

- A formação de novas bases políticas e territórios eleitorais.

A despeito da chegada de outro poder instituído nos territórios carioca e fluminense, não significava que haveria uma ruptura com a configuração institucional estabelecida anteriormente, pois era necessário construir mecanismo que permitissem manter a governabilidade. Era necessário o rompimento com práticas observadas na dimensão espacial da política dos territórios citados, como o clientelismo, a patronagem e o mandonismo.

A Cidade Maravilhosa foi o palco e a vitrine de um partido político e do retorno à política brasileira de um personagem que buscou, através do resgate de elementos presentes em seu passado, como o reformismo e o nacionalismo pré1964 e também da influência de outras nuances como a socialdemocracia europeia, realizar políticas públicas que pudessem criar uma estratégia eleitoral que elevasse Brizola como um líder político de nível nacional. Por esse motivo, o brizolismo buscou na metrópole carioca o alicerce territorial e, através de sua centralidade instituir outra identidade política, já que o amaralismo e o chaguismo estavam bastante enraizados na cidade e no estado do Rio de Janeiro.

O brizolismo pode ser considerado um novo elemento definidor de uma centralidade para o Rio de Janeiro, pois foi determinante na criação de uma representatividade política, destacando assim, o papel simbólico que reveste a questão da capitalidade, escapando do institucionalismo meramente formal que está relacionado a este conceito. Algumas das experiências políticas e ações adotadas pelo governo que se iniciou em março de 1983 destacaram o espaço carioca através de marcas e matrizes que identificam, de forma concreta, o brizolismo com determinadas ações realizadas durante o período em que esteve à frente do executivo estadual. 
A partir de 1983 com o início do governo Brizola e a colocação de seu programa de governo em prática, o projeto do Novo Trabalhismo concebido pela Carta de Lisboa, começou a ganhar concretude.

As marcas deixadas pelas administrações brizolistas possibilitaram pormenorizar realizações e ações que conceberam representações dessa política estabelecida no Rio de Janeiro em que formas e conjunto de formas podem ser quantificados atribuindo significados e percepções não somente quanto ao conteúdo das suas políticas como do modo de fazê-las. Aqui, me refiro à aliança com determinados atores e segmentos da sociedade que passaram ao protagonismo da confecção de políticas públicas, sugerindo marcas espaciais não necessariamente concretas, mas que se espacializaram na cidade através do envolvimento e colaboração de associações de moradores em diferentes áreas e níveis de governo.

Por meio das marcas estabelecidas o brizolismo também foi matriz, porque houve a formação de outra cultura política, a partir de uma estética moral e política, determinada pela Carta de Lisboa, documento fundador do Novo Trabalhismo, que foi definitivo para criação de um novo paradigma político e na forma de fazer política na cidade e no estado do Rio de Janeiro.

No sentido como Brizola observou o Rio de Janeiro, é possível afirmar que esse espaço pode ser considerado uma síntese da nação, pois, ao mesmo tempo, que os problemas localizados na metrópole carioca ganhavam e, por que não dizer, ainda ganham dimensões nacionais, a implementação de políticas públicas em alguns setores considerados sensíveis, como foi o caso da educação, teria a mesma repercussão escalar. Sendo assim, as discussões que imperam o nacional e o local ganham relevante repercussão e também uma dialética não conflituosa permitindo formar uma das representações que conferiram uma nova identidade da política carioca, nesse caso a vitrine do brizolismo.

Observo como factível estabelecer uma conexão entre a capitalidade gerada pelo brizolismo no Rio de Janeiro, tanto pelo estabelecimento de uma identidade política, através de uma conexão com a realidade presente em determinados espaços tanto carioca quanto fluminense, com uma política de atuação não terceirizada, mas tecendo a possibilidade da participação cidadã, seja com relação aos interesses específicos de uma coletividade ao atender pautas concretas, como também por um 
sistema de cooptações não coercitivos da participação popular em determinadas esferas de governo influenciando a concretude das políticas públicas e realizações da administração pedetista.

Através da visibilidade e repercussão que determinadas políticas públicas foram materializadas, estruturou a formação de uma territorialidade desse fenômeno político circunscrito no estado do Rio de Janeiro, principalmente na metrópole carioca. A territorialidade é aqui entendida a partir da identidade que o novo paradigma político a partir de 1983 tomou forma através de novas relações políticas e sociais estabelecidas, além da formação de outra cultura política: a do brizolismo e, também do seu contrário o antibrizolismo.

Portanto, temos uma dimensão política, ou seja, de novas relações de poder que se estabeleceram no Rio de Janeiro e que se afirmaram durante o governo Brizola, através da institucionalização de outra hegemonia política, o que não significa um exclusivismo, dada a complexidade dos diferentes atores políticos que faziam parte dos quadros carioca e fluminense, assim a nuclearização de um novo poder foi resultado de um pacto envolvendo o governo eleito e outros agentes e segmentos sociais como, por exemplo, as associações de moradores. Diante do que foi exposto, é possível afirmar que as relações entre o poder instituído e o instituinte em forma de cooptação de determinados segmentos da sociedade, foi realizado através da participação popular na esfera governamental.

Esse modelo político proposto pelo brizolismo com a participação ativa, não somente de pessoas envolvidas na estrutura partidária, mas também de movimentos sociais, propõe um processo de reconstrução do tecido social, desvinculado da criação das máquinas políticas, fazendo com que a forma de realização da atividade política não seja individualizada, mas que procure atender a demandas específicas de uma determinada coletividade, com isso, há a possibilidade de abandonar práticas patriarcalistas, clientelistas e mandonistas, que fazem parte da engrenagem das máquinas, relacionadas muitas vezes à visão do que chamamos de populismo.

O populismo também é outra discussão marcante nas administrações de Brizola, desde os tempos em que era governador do Rio Grande do Sul. Na verdade mais do que discussão é uma acusação de que suas práticas no poder executivo que foram apontadas tiveram na sua forma de fazer política essa característica. 
Tratar as políticas públicas por um viés populista como de simples cooptação das massas e de manipulação das mesmas, denotando uma política do atraso, não me parece a melhor forma de fazer uma análise, com certa independência dos governos de Brizola. Grande parte das pautas políticas dos seus mandatos esteve relacionada a reivindicações que faziam parte do seu programa de governo, como a educação, a questão da habitação e a formulação de uma política de segurança pública menos agressiva na sua forma de atuar. Temos uma situação em que mais do que classificar as políticas brizolistas como populistas, é de que houve na composição das mesmas uma circularidade política em que a sua montagem conta com problemáticas relacionadas a reivindicações populares, e que muitos desses agentes, sensíveis a situações de vulnerabilidade participaram da sua confecção e da sua implementação.

Houve várias políticas públicas realizadas pelo governo Brizola em que suas montagens corroboram com a afirmação do parágrafo anterior. O exemplo mais conhecido são os Centros Integrados de Educação Pública. Os CIEPs fazem parte de um projeto maior que é o Programa Especial de Educação (PEE). A gestação desse programa foi resultado do Encontro de Mendes em 1983, no início do governo e contou com a participação de professores de vários municípios do estado. Foi através das discussões, encabeçadas pelo vice-governador Darcy Ribeiro que surgiu a ideia da criação dos CIEPs e não somente da expressão e vontade do executivo.

Além da dimensão política, há no brizolismo institucionalizado no Rio de Janeiro desde o primeiro mandato de Brizola, uma multidimensionalidade, com um conteúdo simbólico e cultural delimitado no espaço carioca e fluminense, através de outro paradigma político com a criação de representações que se ancoraram e permitiram a formação de uma nova identidade política enraizada a partir da composição de signos que produziram valores, sejam eles individuais ou coletivos, porém outorgaram a relação de um determinado grupo com um espaço específico, como foi o caso da Brizolândia. Grande parte dessa nova identidade vem a partir de representações criadas pela forma de fazer política gestada com valores e normas que criaram situações de pertencimento ou não de um determinado grupo político e de simpatizantes a ele a partir de comportamentos, experiências e práticas exercidas pelo executivo que assumiu estado. 
Dentre as práticas e experiências que me refiro, posso destacar as relações entre o governo com camadas consideradas marginalizadas, como os movimentos associativistas, um dos pilares da administração brizolista, permitindo maior aproximação com os movimentos sociais e tornando esses atores mais ativos na tomada de decisões, bem como na cooperação para formulação de políticas públicas que atendessem suas necessidades e reivindicações.

Como exemplo, da aproximação das políticas pedetistas com os movimentos sociais, em particular com associações de moradores, temos a escolha do vice-prefeito da gestão de Saturnino Braga, que era presidente da Federação da Associação de Moradores do Estado do Rio de Janeiro, o que evidencia a participação popular na administração do Partido Democrático Trabalhista.

No Rio de Janeiro, espaço de expressão máxima do brizolismo, e de suas políticas públicas, tem as marcas concretas da administração pedetista e que consolidaram ações que passaram a fazer parte da paisagem da cidade engendrando um imaginário brizolista na Cidade Maravilhosa.

O imaginário sobre a literatura acerca de Brizola e do brizolismo não permite uma posição de neutralidade em relação a sua figura e sobre a condução de sua gestão no governo do estado do Rio de Janeiro. A aceitação sobre ele é tão forte quanto a rejeição, por isso para o bem ou para o mal o brizolismo tornou-se tema relevante para as discussões sobre políticas públicas no Rio de Janeiro a partir da década de 1980, em diferentes áreas, seja na educação, na habitação ou na segurança pública.

Algumas políticas realizadas no governo Brizola foram consideradas de grande relevância, e passaram a ser também uma das marcas e do imaginário acerca das realizações brizolistas na Cidade Maravilhosa, principalmente as relacionadas ao Programa Especial de Educação (PEE), que tem nos CIEPs (Centro Integrado de Educação Pública) sua principal vitrine, sendo o programa de maior visibilidade do governo Brizola.

O empreendimento dos CIEPs chegou a ter uma reverberação nacional com a criação no governo do presidente Fernando Collor de Melo dos CIACs (Centro Integrado de Atividades Complementares), com apoio de Brizola e Darcy Ribeiro, 
apesar da rivalidade no campo político e ideológico nas eleições presidenciais de 1989.

Sem dúvida o programa de educação do governo Brizola tanto em seu primeiro quanto no segundo mandato foi a política pública que mais marcou do brizolismo no Rio de Janeiro.

Apesar de não ter a mesma relevância dos CIEPs outra marca do brizolismo no Rio de Janeiro, principalmente na campanha política de 1982, foi movimento conhecido como "Um grito na Praça". A manifestação realizada na Praça Floriano Peixoto, conhecida como Cinelândia pelo seu caráter espontâneo de apoio a Brizola.

A Brizolândia foi um movimento político, que não seguia as diretrizes políticas do Partido Democrático Trabalhista (PDT), como seus integrantes afirmavam, não era uma política cartorializada. No entanto, trabalhava em prol dos candidatos pedetistas e, principalmente, para eleger Leonel Brizola governador do estado do Rio de Janeiro.

O movimento da Brizolândia se apropriou de um dos símbolos da capitalidade da cidade do Rio de Janeiro, um dos principais expoentes da modernização pela qual a metrópole carioca passou no início do século XX, a Praça Marechal Floriano. A praça, pela sua centralidade teve um papel importante, durante os doze anos de existência do movimento.

Pelas suas características, de ser uma praça central, ter grande circulação de pessoas, concebeu ao movimento visibilidade e a possibilidade de cooptar adeptos. A Brizolândia se apropriou de um espaço público. Os espaços públicos se caracterizam pelo uso comum, pelas interações sociais e pela possibilidade de convívio entre os diferentes. Uma das principais características do espaço público é que ele segue normas e regras estabelecidas pelo poder instituído e é exatamente essa condição que permite que seja um espaço marcado pela pluralidade.

No entanto, apesar de o espaço público ser um condicionante para formação do espaço político, o movimento dos brizolistas inaugurado na praça, não era marcado pela pluralidade e nem pelo diálogo. Não permitia a divisão do espaço com grupos e segmentos políticos que não coadunassem das mesmas posições políticas, portanto o primarismo político era uma das características da Brizolândia. 
Temos na Brizolândia um espaço da ação política, da coletividade que é determinado pela praça, através de seus diversos usos, com atores sociais distintos e que por um período do dia, principalmente no final da tarde, horário em que a movimentação de trabalhadores aumenta, se transmuta em espaço da política brizolista, espaço “aberto" para todos que tinham por opção apoiar e eleger Brizola. Esse mesmo espaço da política brizolista, com a forma inorgânica de fazer política, pela maneira de atuar, era a negação da mesma, por isso, essa apropriação pode ser classificada como um espaço "apolítico".

Portanto, para além da influência que o brizolismo teve e tem principalmente na cidade do Rio de Janeiro, seja pelos mandatos do PDT ou pelas marcas deixadas pelas gestões pedetistas, as suas ações políticas ainda fazem parte do imaginário eleitoral do Rio de Janeiro.

A 'Cidade Maravilhosa' continua sendo o território do brizolismo no Brasil. Por isso, não observo nenhum contratempo em afirmar que houve uma simbiose entre Brizola, brizolismo e o Rio de Janeiro, apesar de todas as reações que a figura do ex-governador possa suscitar. A imagem de Brizola não deixa meio termo, pois ao mesmo tempo em que há os brizolistas, temos sua antítese, os antibrizolistas.

Assim, por mais contraditórias que tenham sido as visões sobre seus dois governos e a longa trajetória política, ainda surgem políticas públicas que levam um pouco da sua marca. Dessa forma, termino com a frase utilizada por muitos brizolistas: "Brizola vive". 


\section{Referências bibliográficas}

AGUIAR, Ricardo Osman g. Leonel Brizola: uma trajetória política. Rio de Janeiro: Record, 1991.

ALKMIM, Antônio Carlos; KUSCHNIR, Karina. Mapas eleitorais fluminenses. In: Um Estado em questão: os 25 anos do Rio de Janeiro. Freire, Américo, Sarmento, Carlos Eduardo e Motta, Marly Silva da. Rio de Janeiro: Editora FGV, $1^{\text {a }}$ Edição, 2001.

AMORIM, Paulo Henrique; PASSOS, Maria Helena. Plim-Plim: a peleja de Brizola contra a fraude eleitoral. São Paulo: Conrad Editora do Brasil, 2005.

ANDRADE, Luciana Teixeira de; BAPTISTA, Luís Vicente. Espaço Público: interações, apropriações e conflitos. Revista da Faculdade de Letras. Universidade do Porto. Portugal. V. XXIX. P. 129-146, 2015.

AZEVEDO, André Nunes. A grande reforma urbana do Rio de Janeiro: Pereira Passos, Rodrigues Alves e as ideias de civilização e progresso. Rio de Janeiro: Ed. PUC-Rio, 2016.

BALOYRA, Enrique A. Os vários momentos da transição política no Brasil, 1977-1981. In: Selcher, Wayne A. (org.). A Abertura Política no Brasil: dinâmica, dilemas e perspectivas. São Paulo: Convívio, 1988.

BANDEIRA, Moniz. Brizola e o trabalhismo. Civilização Brasileira, 1979.

BARBOZA, S. C. Políticas e programas habitacionais no município do Rio de Janeiro: uma avaliação da experiência (1979-2002). Niterói: Dissertação (Mestrado em Arquitetura e Urbanismo) - Universidade Federal Fluminense, 2013.

BERQUE, Augustin. Paisagem-Marca, Paisagem-Matriz: Elementos de uma Problemática para uma Geografia Cultural. In: Corrêa, Roberto Lobato e Rosendahl, Zeny (Orgs.). Paisagem, Tempo e Cultura. Rio de Janeiro: Ed. UERJ, 1998 .

BORJA, J. La ciudad conquistada. Madrid: Alianza Editorial, 2003.

BRAGA, Danilo Fiani. Geografia Eleitoral e as Estratégias Territoriais da Igreja Universal do Reino de Deus. In: Castro, Iná Elias de et alli.(Orgs.). Espaços da Democracia: para a agenda da geografia política. 1 ed. Rio de Janeiro: Bertrand Brasil, Faperj, 2013.

BRASIL. Partidos Políticos Brasileiros: programas e diretrizes doutrinárias. Brasília: Senado Federal, Coordenação de Edições Técnicas, 2014. 
BRESSER-PEREIRA, Luiz. Os limites da "abertura" e a sociedade civil. In: Fleischer, David (org.). Da distensão à abertura: as eleições de 1982. Brasília: editora Universidade de Brasília, 1988.

Pactos Políticos: do populismo à redemocratização. São Paulo: Editora Brasiliense, 1985.

BRITTO, Luiz Navarro. As eleições de 1982 e as suas consequências. In: Fleischer, David. Da distensão à abertura: as eleições de 1982. Brasília: editora Universidade de Brasília, 1988.

CACCIA. Lara Schmitt. A Apropriação do Espaço público a partir do estudo das representações sociais no Parque da Redenção em Porto Alegre/RS. Dissertação de Mestrado. Universidade Federal do Rio Grande do Sul. Instituto de Geociências, Departamento de Geografia. Porto Alegre, 2009.

CASTRO, Iná Elias de. Entre a política e a nova agenda da Geografia. Revista Continentes (UFRRJ), ano 4, n.7, 2015.

Espaços públicos: entre a publicidade e a política. ALCEU. V.4, n.8, p. 141-155, jan/jun. 2004.

CASTRO, Iná Elias de. Geografia e política: território, escalas de ação e instituições. $2^{\text {a }}$ Ed. Rio de Janeiro: Bertrand Brasil, 2009.

CERQUEIRA. Carlos Magno Nazareth. "Remilitarização da segurança pública: a Operação Rio". In: Revista de Discursos Sediciosos. Rio de Janeiro: ICC, ${ }^{\circ} 1$, 1996.

COMPANS, Rose. A regularização fundiária de favelas no Rio de Janeiro. Revista Rio de Janeiro, n.9, p. 41-53, jan/abr, 2003.

CORRÊA. Roberto Lobato. Formas simbólicas e espaço: algumas considerações. Geographia. Ano IX. No 7. 2007.

COSTA, Izabel Cristina Gomes da. Em busca do paradigma perdido: as esquerdas brasileiras e a crise do socialismo real. Tese de Doutorado. Universidade Federal Fluminense, Instituto de Ciências Humanas e Filosofia, Departamento de História. Rio de Janeiro, 2009.

COSTA, Rafael Navarro. As memórias do comandante: Amaral Peixoto e a política fluminense. Histórica - Revista Eletrônica do Arquivo Público do estado de São Paulo, nº 35, 2009.

COSTA, Sérgio. Contextos da Construção do Espaço Público no Brasil. Revista Novos Estudos CEBRAP. São Paulo. N. 47, março, 1997.

D'ARAÚJO, Maria Celina. Sindicatos, carisma e poder: o PTB de 1945 a 1965. Rio de Janeiro: Fundação Getulio Vargas, 1996. 
DEBERT, Guita Grin. Ideologia e Populismo: Ademar de Barros, Miguel Arraes, Carlos Lacerda e Leonel Brizola. São Paulo: T. A. Queiroz, 1979.

DELGADO. Lucília de Almeida Neves. Trabalhismo, nacionalismo e desenvolvimentismo: um projeto para o Brasil (1945-1964). In: Delgado, Lucília de Almeida Neves e Ferreira, Jorge (orgs.). O Brasil republicano: o tempo da experiência democrática - da democratização de 45 ao golpe civil-militar de 64 . Vol. 3. RJ: Civilização Brasileira, 2003.

DINIZ, Eli. Voto e máquina política: patronagem e clientelismo no Rio de Janeiro. Rio de Janeiro: Paz e Terra, 1982.

DUVEEN, Gerard. Crianças enquanto atores sociais: as Representações Sociais em Desenvolvimento. In: Guareschi, Pedrinho e Jovchelovitcht, Sandra (orgs.). textos em Representações Sociais. $2^{\mathrm{a}}$ Edição, Petrópolis, RJ: Vozes, 1995.

Empresariado e Transição Política no Brasil: problemas e perspectivas. In: Fleischer, David). Da distensão à abertura: as eleições de 1982. Brasília: editora Universidade de Brasília, 1988.

EMERIQUE, Raquel Balmant. Do salvacionismo a segregação: a experiência dos Centros Integrados de Educação Pública no Rio de Janeiro. Dissertação de Mestrado. UERJ, 1997.

FARIA, Lia. Chaguismo e Brizolismo: territorialidades políticas da escola fluminense. Rio de Janeiro: FAPERJ: Quartet, 2001.

FLEISCHER, David. O Novo Pluripartidarismo: Perfil Socioeconômico da Câmara dos Deputados (1979 versus 1983). In: Fleischer, David. Da distensão à abertura: as eleições de 1982. Brasília: editora Universidade de Brasília, 1988.

GOMES, Ângela Maria de Castro. A invenção do trabalhismo. Rio de Janeiro, $3^{\mathrm{a}}$ Edição. Editora FGV, 2005.

GOMES, Paulo César da Costa. A condição urbana: ensaios de geopolítica da cidade. Rio de Janeiro: Bertrand Brasil. p. 304, 2002.

GOMES, Paulo César da Costa. Geografia fin-de-siécle: o discurso sobre a ordem espacial do mundo e o fim das ilusões. In: Castro, Iná E. et. al. (Orgs.). Explorações Geográficas. Rio de Janeiro: Ed. Bertrand, p. 13-43, 1997.

GRIJÓ, Luís Alberto. Alberto Pasqualini: o teórico do trabalhismo. In: Ferreira, Jorge e Reis, Daniel Aarão (orgs.). As esquerdas no Brasil: nacionalismo e reformismo radical. 1945-1964. Volume 2. RJ: Civilização Brasileira, 2007.

INDOVINA, F. O Espaço público: tópicos sobre sua mudança. Revista Cidade, Comunidades e Territórios, Lisboa. Instituto Superior de Ciências do Trabalho e Empresa (ISCTE), n. 5, p. 119-123, 2002.

JODELET, Denise. As Representações Sociais. Rio de Janeiro: Ed.UERJ, 1988. 
JOVCHELOVITCH, Sandra. Representações sociais e esfera pública: construção simbólica dos espaços públicos no Brasil. Petrópolis: RJ. Vozes, 2000 .

JOVCHELOVITCH, Sandra; GUARESCHI, Pedrinho. Introdução. In: Jovchelovitch, Sandra e Guareschi, Pedrinho. Textos em representações sociais. $2^{\mathrm{a}}$ Edição, Petrópolis: RJ: Vozes,1995.

JÚNIOR, Francisco Machado Carrion. Brizola: momentos de decisão. $2^{\mathrm{a}}$ Edição. São Paulo L e PM Editora, 1989.

JUWER, Vinícius Ventura Silva e. A Geografia Eleitoral dos Grupos Criminosos na Cidade do Rio de Janeiro. In: Castro, Iná Elias de et alli.(Orgs.). Espaços da Democracia: para a agenda da geografia política. 1 ed. Rio de Janeiro: Bertrand Brasil, Faperj, 2013.

LAFER, Celso. O Brasil e a crise mundial. Coleção Debates. Editora Perspectiva. São Paulo, 1984.

LAMOUNIER, Bolivar (Org.). Voto de Desconfiança: Eleições e Mudança Política no Brasil, 1970-1979. Petrópolis - RJ: Editora Vozes, 1980.

As eleições de 1982 e a abertura política em perspectiva. In: Trindade, Hélgio (org.). Brasil em perspectiva: Dilemas da abertura política. Porto Alegre: Sulima, 1982.

LAURENTINO, Fernando de Pádua. Espaço Público: espaço de conflitos. Projeto História. São Paulo, n.33, p. 307-317, dez. 2006.

LAVALLE, Adrián Gurza. As dimensões constitutivas do espaço público: uma abordagem pré-teórica para lidar com a teoria. Espaço e Debates: Revista de Estudos regionais e urbanos. São Paulo. N.46. v. 25. p. 33-44, 2005.

LEIB, J. I. Separated Times, Shared Spaces: Arthur Ashe, Monument Avenue and Politics of Richmond, Virginia, Symbolic Landscape. Cultural Geography, 9, pp. 286-312, 2002.

LEITE FILHO, F.C. El Caudilho Leonel Brizola: um perfil bibliográfico. $1^{\text {a }}$ Edição. São Paulo: Aquariana, 2008.

LIMA, Wendell Teles; FRAGA, Nilson César; SILVA, Iatiçara Oliveira. A Geografia Eleitoral da Representatividade no Brasil Atual. Revista de Geopolítica, Natal, v.5, nº 1, p.130-139, jan./jun. 2014.

LOPES, Nelson Ricardo Mendes. Coronelismo me chaguismo na zona oeste do Rio de Janeiro: clientelismo ou coronel, o caso das bicas d'água no Mendanha. Dissertação de Mestrado. Universidade do Estado do Rio de Janeiro: Rio de Janeiro, 2007. 
MATTOS FILHO, Jorge Luiz. Empresas de Transporte e Poder: um estudo sobre o papel do estado na formação das empresas de ônibus no município do Rio de Janeiro e o processo de encampação no governo Leonel Brizola. Dissertação de Mestrado em Ciências Sociais. Universidade Federal Rural do Rio de Janeiro, 2018.

MISSE, Michel. Os rearranjos de poder no Rio de Janeiro. Le Monde Diplomatique - Brasil, jul, 2011.

MOSCOVICI, Serge. Representações Sociais: investigações em psicologia social. Petrópolis: RJ: Vozes, 2009.

MOTTA, Marly da Silva. O Rio de Janeiro continua sendo. Seminário Rio de Janeiro: capital e capitalidade. Rio de Janeiro, CPDOC, 14f. 2000.

Rio, cidade-capital. Rio de Janeiro: Jorge Zahar Editora, 2004.

MOURA, Emanuel Fonseca Gomes de. Espaço Público: reabilitação urbana no Centro Histórico de Vila Real. Dissertação de Mestrado, Universidade da Beira Interior: Portugal, 2016.

NARCIZO, Carla Alexandra Filipe. Espaço público: acção política e práticas de apropriação. Conceitos e procedimentos. Estudos e Pesquisas em Psicologia. UERJ-RJ. Ano 9. N.2. P. 265-291. $2^{\circ}$ Semestre, 2009.

NEVES, Gabriela Klôh Müller. Ações e descontinuidades na política habitacional no Rio de Janeiro: o descompasso entre a concepção e a implementação de programas habitacionais nos governos Leonel Brizola e Moreira Franco (1983-1995). Dissertação de Mestrado. Rio de Janeiro: UFRJ/IFCS, 2007.

NUNES, Juliana; SANFELICI, Daniel. Ambiente Institucional e Diversidade Territorial: considerações para uma agenda de pesquisa. GEOgraphia, vol. 20, n. 44 , set./dez. 2018.

OLIVEIRA, Herbert Santos. A razão indignada: Leonel Brizola em dois tempos (1961-1964) e (1979-2004). Revista Eletrônica Discente História.com, Cachoeira, v.4, n.7, p. 143-147, 2017.

OSÓRIO, Mauro. Rio Nacional, Rio Local: mitos e visões da crise carioca e fluminense. Rio de Janeiro: Editora Senac Rio, 2005.

PANEBIANCO, A. Modelos de partido: organização e poder nos partidos políticos. São Paulo: Martins Fontes, 2005.

PDT. Partido Democrático Trabalhista: Estatuto, Cartas, Manifesto, Programa, Artigos e Textos. Caminho Brasileiro para o Socialismo. Rio de Janeiro, junho 2006. 
PEREIRA, Leonardo Rodrigues. Marcas e matrizes da construção da paisagem urbana no Alto da Boa Vista, Rio de Janeiro. In: Migliorini, Jeanine Mafra. Arquitetura e Urbanismo: abordagem polivalente 2. Ponta Grossa. PR: Atena, 2020.

PERLONGHER, Nestor. Territórios marginais. In: Antonio Lancetti (Org.). Saúde e loucura de grupos coletivos. São Paulo: HUCITEC, p. 49-69 1993.

REIS, J. Ensaios de Economia Impura. Coimbra: Edições Almedina. 2009.

RONCAYOLO, M. "Território". In: Enciclopédia Einaudi, v. 8 pp. 262-90 Região Cidade do Porto: Imprensa Nacional, 1986.

ROWNTREE, J. B; CONLEY, M. W. Symbolism and the Cultural Landscape. Annals os the Association of Amaerican Geographers, pp. 459-79. 1980.

SACK. Robert D. Human territotiality - It's theory and history. Cambridge: Cambridge University Press, 1986.

SANTOS, Milton. Espaço e Método. São Paulo: Studio Nobel, 1986.

SELCHER, Wayne A. Contradições e protagonistas da Abertura no Brasil, 1979-1985. In: Selcher, Wayne A. (org.). A Abertura Política no Brasil: dinâmica, dilemas e perspectivas. São Paulo: Convívio, 1988.

Introdução. In: Selcher, Wayne A. (org.). A Abertura Política no Brasil: dinâmica, dilemas e perspectivas. São Paulo: Convívio, 1988.

SELL, Carlos Eduardo. A Liderança Carismática: sobre o caráter político do populismo. Revista Tomo. Universidade Federal de Sergipe. Dezembro, 2013.

SENTO-SÉ, João Trajano. As várias cores do socialismo moreno. Anos 90. Porto Alegre. V. 11, n. 19/20, p. 49-76. Jan/dez, 2004.

Editora FGV, 1999.

Brizolismo: estetização da política e carisma. Rio de Janeiro:

SERPA. A. Espaço público e acessibilidade: notas para uma abordagem geográfica. Revista GEOUSP - Espaço e Tempo, São Paulo, n.15, p. 21-37, 2004.

SILVA, Augusto César Pinheiro da. Gestão Territorial em Regiões Metropolitanas: agendas necessárias para uma governança cooperativa e coparticipativa - o exemplo do Rio de Janeiro. In: Silva, Augusto César Pinheiro da Silva (org.). Geografia Política, geopolítica e gestão do território: racionalidades e práticas em múltiplas escalas: contribuições do I CONGEO para pesquisa geográfica no Brasil. Rio de Janeiro: Gramma, 2016.

SILVA, Bruno Marques. Reformar a polícia e pensar a cidade: o policiamento comunitário e a segurança pública pedetista no Rio de Janeiro (1983-1995). Revista Libertas. Juiz de Fora, v.15, n.2, p. 189-214, ago/dez. 2015. 
SOBARZO, Oscar. A produção do espaço público: da dominação a apropriação. Espaço e Tempo. GEOUSP. N. 19 p. 93-111, São Paulo, 2008.

SOUZA, Ernani Corrêa de. Brizolândia: um grito na praça. Rio de Janeiro, 1993.

TERRON, Sonia Luiza. A composição de territórios eleitorais no Brasil. Uma análise das votações de Lula (1989 - 2006). Tese de Doutorado. IUPERJ. Rio de Janeiro, 2009.

VERSIANI, Maria Helena; OSÓRIO, Mauro. História da capitalidade do Rio de Janeiro. Cadernos do Desenvolvimento Fluminense. Rio de Janeiro, n. 7 pp. 75 90. Jan/jun, 2019.

WEFFORT, Francisco. Política e massas. In Gabriel Cohn; Octavio Ianni; Paul Singer (orgs.). Política e revolução social no Brasil. Rio de Janeiro, Civilização Brasileira, 1965. 